\title{
Ground-Water Hydrology of the Tacoma-Puyallup Area, Pierce County, Washington
}

\author{
By M. A. Jones, L. A. Orr, J. C. Ebbert, and S. S. Sumioka
}

\section{U.S. GEOLOGICAL SURVEY}

Water-Resources Investigations Report 99-4013

Prepared in cooperation with the

WASHINGTON DEPARTMENT OF ECOLOGY,

TACOMA-PIERCE COUNTY HEALTH DEPARTMENT,

CITY OF PUYALLUP, AND

CITY OF TACOMA 


\title{
U.S. DEPARTMENT OF THE INTERIOR \\ BRUCE BABBITT, Secretary
}

\author{
U.S. GEOLOGICAL SURVEY
}

Charles G. Groat, Director

Any use of trade, product, or firm names is for descriptive purposes only and does not imply endorsement by the U.S. Geological Survey.

For additional information write to:

District Chief

U.S. Geological Survey

1201 Pacific Avenue, Suite 600

Tacoma, Washington 98402
Copies of this report may be purchased from:

U.S. Geological Survey

Branch of Information Services

Box 25286

Denver, Colorado 80225 


\section{CONTENTS}

Abstract-1

Introduction -

Purpose and scope-1

Description of the study area - 3

Well-numbering system -

Acknowledgments -

Study methods

Hydrogeologic methods - 7

Water-use methods -

Water-quality methods- 11

Hydrogeologic framework -

Ground-water system -

Ground-water recharge --_.-_- 35

Ground-water movement-_._-_._. 37

Water-level fluctuations -

Ground-water discharge - 58

Natural discharge-- 58

Water use -

Ground-water budget - 63

Ground-water quality - - 64

Conceptual model of factors affecting water quality - 70

Effects of land-use activities on water quality - 70

Nitrate-- 70

Pesticides and volatile organic compounds - 73

Bacteria --_.-.- 79

Other factors affecting water quality - 79

Quality assurance of water-quality data- 83

Standard reference samples -83

Duplicate and replicate samples-- 86

Blanks-- 86

Cation-anion balance -

Checks on field values -..-_._- 90

Summary and conclusions -

Selected references-_- 91

Appendix 1. Physical and hydrologic data for the wells and springs in the Tacoma-Puyallup area, Wash. --- 109

Appendix 2. Drillers' lithologic logs of wells used in construction of hydrogeologic sections, in the

Tacoma-Puyallup area, Wash. -

Appendix 3. Water-quality data, in the Tacoma-Puyallup area, Wash.

\section{FIGURES}

1. Map showing location of the study area-

2. Map showing well- and spring-numbering system used in Washington -

3. Map showing locations of wells and springs inventoried in the Tacoma-Puyallup area, Wash. - -

4. Diagram of ground-water sampling system and equipment precision- 19

5. Map showing thickness of unconsolidated deposits in the Tacoma-Puyallup area, Wash. -.............. 21 


\section{FIGURES--Continued}

6. Map showing distribution of hydrogeologic units at land surface, inventoried wells, and traces of the hydrogeologic sections $A-A^{\prime}$ to $E-E^{\prime}$ in the Tacoma-Puyallup area, Wash. -

7. Hydrogeologic sections $A-A^{\prime}$ to $E-E^{\prime}$, showing locations of hydrogeologic units in the Tacoma-

Puyallup area, Wash. -- $A$

8-12. Maps showing altitude of the top and extent of hydrogeologic units in the Tacoma-Puyallup area, Wash.:

8. Qvr - 28

9. Qvt -..- 29

10. Qc1 - 31

11. Qf1 - 32

12. Qc2 - 33

13. Map showing distribution of estimated ground-water recharge in the study area, in inches per year in the Tacoma-Puyallup area, Wash. -- 36

14. Map showing water-level altitude in aquifer $\mathrm{Qc1}$. Water levels were compiled from current and historical data in the Tacoma-Puyallup area, Wash. - - 38

15. Map showing water-level altitude in aquifer Qc2. Water levels were compiled from current and historical data in the Tacoma-Puyallup area, Wash. -...- 39

16. Map showing locations of bimonthly water-level observation wells in the Tacoma-Puyallup area, Wash.

17a-e. Graphs showing water levels and where available, specific conductance measurements for the

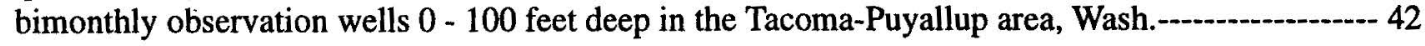

18. Map showing locations of wells and springs sampled for water quality in 1996 in the TacomaPuyallup area, Wash.

19. Graphs showing relation between hydrogeologic unit and depth to first opening, specific

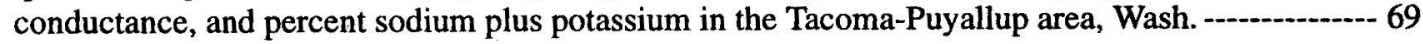

20. Schematic diagram showing overview of ground-water quality and factors affecting it -.-.-.-.-.--- 71

21. Map showing concentrations of nitrite plus nitrate in water sampled from wells and springs, 1996 in the Tacoma-Puyallup area, Wash.

22. Graph showing trends in concentrations of nitrate and chloride in water from Maplewood Spring, 1936-96 in the Tacoma-Puyallup area, Wash

23. Graph showing trend in concentration of nitrate in water from Maplewood Spring, 1988-94 in the Tacoma-Puyallup area, Wash.

24. Map showing locations of wells and springs sampled for pesticides and where pesticides were detected, 1996 in the Tacoma-Puyallup area, Wash.

25. Map showing locations of wells and springs sampled for volatile organic compounds (VOCs) and where VOCs were detected, 1996 in the Tacoma-Puyallup area, Wash. - 80

26. Map showing locations of wells and springs sampled for bacteria and where bacteria were detected, 1996 in the Tacoma-Puyallup area, Wash.

27. Graphs showing relation between hydrogeologic unit and depth to the first opening, concentrations of nitrate, and dissolved oxygen in the Tacoma-Puyallup area, Wash.

28. Graph showing cation and anion percent difference - 90

\section{TABLES}

1. Chemical Abstract Services registry number and minimum reporting level for selected major ions, trace elements, and other constituents -- 12

2. Volatile organic compound analyzed for, Chemical Abstract Services registry number, and minimum reporting level---on 13

3. Pesticide target analytes, Chemical Abstract Services registry number, method detection limits, and drinking water standards --..-- 15

4. Summary of hydraulic conductivity values estimated from specific capacity of wells, by hydrogeologic unit in the Tacoma-Puyallup area, Washington 


\section{TABLES--Continued}

5. Summary of water-level and specific conductance data for the 1996 water year in the TacomaPuyallup area, Washington-

6. Records of springs inventoried for this study during 1995 and 1996 in the Tacoma-Puyallup, area, Washington

7. Summary of estimated water use during 1996 by water-use category, source, and hydrogeologic unit in the Tacoma-Puyallup area, Washington

8. Matrix indicating analyses performed on sample from well or spring and hydrogeologic unit tapped by well or spring in the Tacoma-Puyallup area, Washington - 66

9. Summary of concentrations of inorganic constituents, trace elements, and bacteria, values of other properties, concentrations of pesticides and volatile organic compounds detected, and associated drinking water standards or guidelines, in the Tacoma-Puyallup area, Washington ---.-- 67

10. Concentrations of nitrate and chloride in water from Maplewood Spring, in the Tacoma-Puyallup area, Washington - 75

11. Estimated error in analysis of inorganic constituents - 85

12. Constituent concentrations in duplicate samples - 87

13. Replicate sample results for bacteria determinations -

14. Summary of constituent concentrations reported for blank samples -

15. Altitude of top of hydrogeologic units in wells in the Tacoma-Puyallup area, Washington-........... 100

\section{CONVERSION FACTORS AND VERTICAL DATUM}

\begin{tabular}{rcl} 
Multiply & By & To obtain \\
\hline inch (in.) & 25.4 & millimeter \\
foot (ft) & 0.3048 & meter \\
foot per mile $\left(\mathrm{ft} / \mathrm{mi}^{2}\right)$ & 0.1894 & meter per kilometer \\
square foot $\left(\mathrm{ft}^{2}\right)$ & 0.0929 & square meter \\
acre & 0.4047 & hectare \\
& 4,047 & square meter \\
acre-foot $(\mathrm{acre}-\mathrm{ft})$ & 1,233 & cubic meter \\
cubic foot $\left(\mathrm{ft}^{3}\right)$ & 0.02832 & cubic meter \\
cubic foot per second & & cubic meter per second \\
per mile $\left(\mathrm{ft}^{3} / \mathrm{s} / \mathrm{mi}^{3}\right)$ & 0.0176 & per kilometer \\
cubic foot per second per & & cubic meter per second \\
square mile $\left(\mathrm{ft}^{3} / \mathrm{s} / \mathrm{mi}^{2}\right)$ & 0.01093 & per square kilometer \\
cubic foot $\left(\mathrm{ft}^{3}\right)$ & 28.32 & liter \\
mile $(\mathrm{mi})$ & 1.609 & kilometer \\
square mile $\left(\mathrm{mi}^{2}\right)$ & 2.590 & square kilometer \\
gallon $(\mathrm{gal})$ & 3.785 & liter \\
million gallons per day $(\mathrm{Mgal} / \mathrm{d})$ & 0.04381 & cubic meter per second
\end{tabular}

Temperature: To convert temperature given in this report in degrees Fahrenheit $\left({ }^{\circ} \mathrm{F}\right)$ to degrees Celsius $\left({ }^{\circ} \mathrm{C}\right)$, use the following equation: ${ }^{\circ} \mathrm{C}=5 / 9\left({ }^{\circ} \mathrm{F}-32\right)$.

Sea Level: In this report "sea level" refers to the National Geodetic Vertical Datum of 1929 (NGVD of 1929)-a geodetic datum derived from a general adjustment of the first-order level nets of both the United States and Canada, formerly called Sea Level Datum of 1929.

Altitude: In this report, altitude is measured in feet above sea level. 


\title{
Ground-Water Hydrology of the Tacoma-Puyallup Area, Pierce County, Washington
}

\author{
By M. A. Jones, L. A. Orr, J. C. Ebbert, and S. S. Sumioka
}

\begin{abstract}
The northwestern part of Pierce County, Washington, is undergoing growth in population and in urban development, creating increased demands for municipal and domestic water supplies. Because most surface waters are already appropriated, ground-water resources are expected to meet the increasing demands. This report describes the ground-water system in the Quaternary deposits of this area.
\end{abstract}

The 88-square-mile study area is underlain by unconsolidated Quaternary deposits as much as 1,800 feet thick. Subsurface stratigraphy was delineated by extrapolating information from published surficial geologic maps and from 255 drillers' lithologic logs. The preparation of 17 sections aided in defining 10 hydrogeologic units-5 aquifers 5 semiconfining units--and 1 undifferentiated unit. Maps of the five uppermost units show the extent and topography of the tops of those units. The two major aquifers are units Qc1 and Qc2.

Precipitation over the study area averages an estimated 38 inches per year. Of this, 14 inches per year enters the ground-water system as recharge. Ground water generally moves northward to Puget Sound and east and northeast to the Puyallup River. Locally, the ground water discharges to streams, creeks, and springs within the study area. Discharge from these areas is estimated at 11 inches per year. Another 4.5 inches per year is withdrawn from wells.

During the 1996 water year, 22 billion gallons of water were used to supply the study area's needs. Of this, 15 billion gallons were imported from surface-water sources outside the study area. Approximately 9 billion gallons of water were used for commercial and industrial supplies and 8 billion gallons for public supplies. Much of the remainder was used for domestic supplies, agriculture, aquaculture, and irrigation.

The overall quality of the ground water in the study area is good based on information from the sampled site. Four constituents were found at concentrations above primary drinking water standards or guidelines. Two of the four constituents, the pesticide dieldrin in water from one well and total coliform bacteria in water from four wells or springs, were at levels exceeding standards or guidelines related to human health. Concentrations of iron or manganese in water from eight wells and springs exceeded secondary drinking water standards. Concentrations of iron or manganese in ground water above secondary drinking water standards are common for the Puget Sound region. Concentrations of the other constituents were below drinking water standards or guidelines.

\section{INTRODUCTION}

The northwestern part of Pierce County (fig. 1) is one of several areas in the Puget Sound region of western Washington that is experiencing rapid growth in population and urban development and therefore has increasing demands for water for public supply, domestic, commercial, and industrial uses. Historically, the area has relied on surface water from the Green River and ground water from local springs and wells to meet water demands. However, increasing demands have resulted in several municipalities in northwestern Pierce County drilling additional public-supply wells or replacing older wells with more productive wells to satisfy both normal and peaking water demands. 


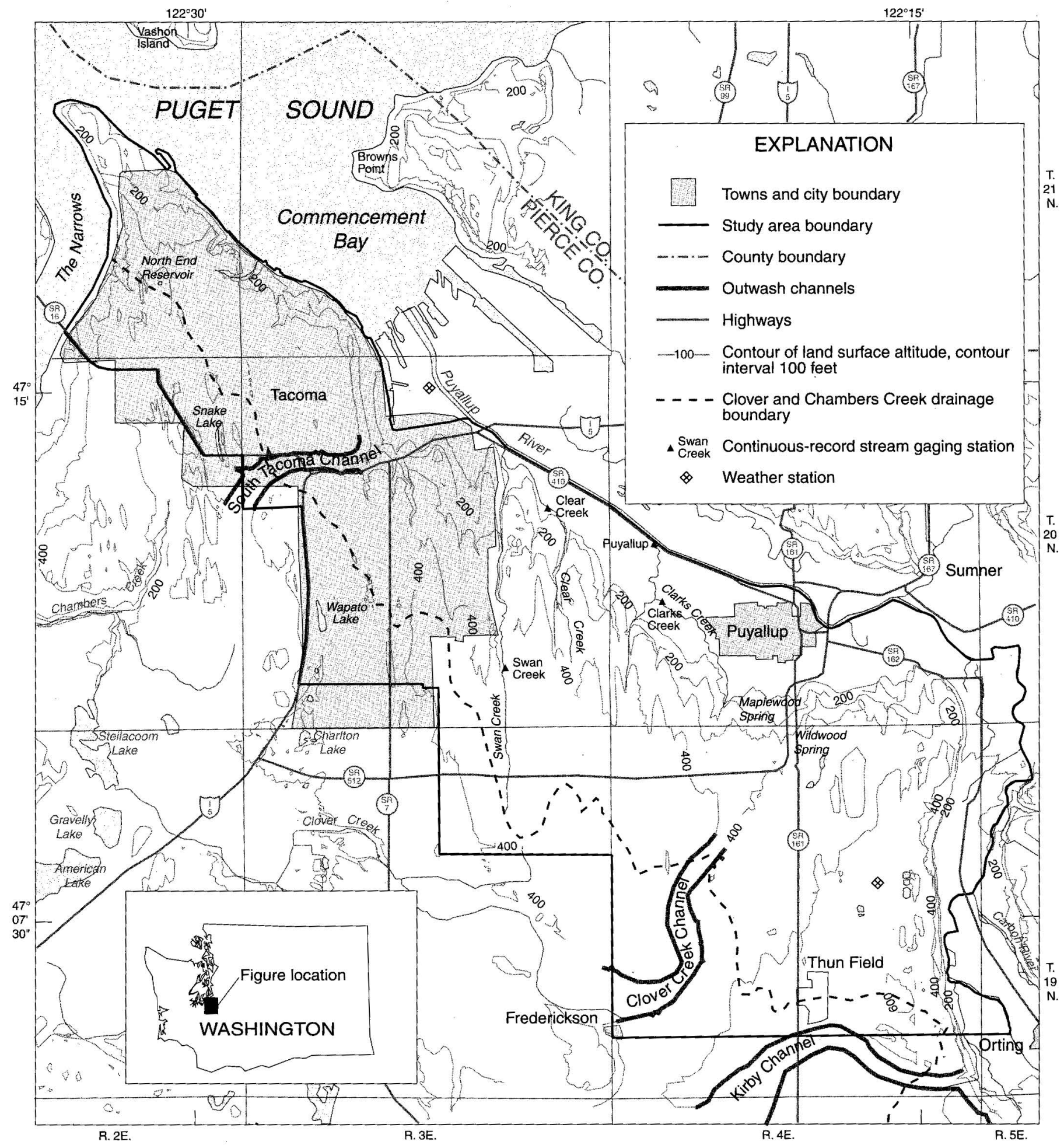

$\begin{array}{ccccccc}0 & & 1 & 2 & 3 & 4 & 5 \text { MILES } \\ 1 & 1 & I_{1} & I_{1} & & 3 & I_{1} \\ 0 & 1 & 2 & 3 & 4 & 5 \text { KILOMETERS }\end{array}$

Figure 1. Location of the study area. 
The availability of ground water and the effects of withdrawals from wells on nearby wells, lakes, springs, and wetlands are becoming important issues. The Washington Department of Ecology (Ecology), which manages the State's water resources and issues rights for both ground- and surface-water withdrawals, has currently limited appropriations for ground water within the study area and no longer issues them for surface water there because these rights have been fully appropriated. Thus, many municipalities have transferred appropriations from older, less productive wells to newly drilled, more productive wells. Another concern is that ground-water recharge may be reduced by current land development that impedes precipitation from infiltrating downward into the ground, thus increasing surface runoff and the potential of flooding during large storms.

In addition, ground-water quality is of concern. These concerns include potential contamination related to industrial and waste-disposal practices, the distribution and large number of septic systems in the area, land-use practices, the potential for seawater intrusion along the shore of Puget Sound, and large iron and manganese concentrations that naturally occur in some of the wells completed in Quaternary deposits.

In order to plan for the development, use, and management of the water resources of the area, a better understanding of the entire natural hydrologic system is needed, including the geometry of the aquifers and semiconfining units, directions of the ground-water movement system, water-quantity characteristics, recharge rates, and the water budget.

Concerns about how to effectively plan and provide for the increased water demand for the rapidly increasing industrial and residential growth in northwestern Pierce County are not new. Regional studies evaluating the ground-water resources in the Tacoma-Pierce County area were conducted in the mid 1930's (LaRocque and Piper, 1938; and Piper and LaRocque, 1938) and continued through the late 1960's (Griffin and others, 1962; and Walters and Kimmel, 1968).

Since the completion of these studies, state and local agencies responsible for managing the water resources have become increasingly concerned about ground-water quantity and quality problems. Thus, in 1995, the U.S. Geological Survey (USGS) began a cooperative study to assess the ground-water system of the Quaternary deposits that underlie northwestern Pierce County. Agencies cooperating with the USGS in this study include Ecology, the Tacoma-Pierce County Health Department, the City of
Puyallup, and the City of Tacoma. The objectives of the study were to

(1) describe and quantify the ground-water system to the extent allowed using available and readily collectible data;

(2) describe the general water chemistry of the major hydrogeologic units and any regional patterns of contamination; and

(3) prepare a water budget of the study area.

\section{Purpose and Scope}

This report describes and quantifies the ground-water system in the Quaternary deposits in northwestern Pierce County, based on the objectives listed in the Introduction section. The report includes descriptions of the geometry and physical characteristics of selected hydrogeologic units, ground-water movement system, recharge, water use, water-level fluctuations, and general ground-water chemistry.

\section{Description of the Study Area}

The northwestern Pierce County study area is irregularly shaped and covers $88 \mathrm{mi}^{2}$ (square miles) (fig. 1). The area is bounded on the northwest by The Narrows and on the north by Puget Sound and Commencement Bay. The Puyallup River forms the boundary from Commencement Bay on the north, along the east side of the study area to just west of the town of Orting. The southern boundary extends from Orting west to the town of Frederickson. The southwestern boundary approximately follows the northeastern drainage divides of Clover and Chambers Creeks (fig. 1).

The physiography of the study area is a product of the most recent glaciation and the more recent alluvial processes of the Quaternary Period. The study area consists of an upland drift plain that covers most of the study area and has been transected by three glacial outwash channels and of an alluvial valley on the east that is part of the Puyallup River Valley.

The upland drift plain ranges from 200 to $600 \mathrm{ft}$ (feet) above sea level and is generally composed of fine-grained deposits. The outwash channels that traverse the upland drift plain are from north to south, the South Tacoma, Clover Creek, and Kirby Channels (Bretz, 1913; and Walters and Kimmel, 1968) (fig. 1). The outwash channels were cut by meltwater streams formed when successively lower outlets from an ice-dammed lake were 
exposed as a glacier receded from the Puget Sound Lowland. As lower outlets formed, the outwash filled channels with coarse-grained sand and gravel deposits.

The Puyallup River Valley ranges in altitude from sea level near Tacoma to $150 \mathrm{ft}$ near Orting (fig. 1). The valley floor is composed of coarse- to fine-grained deposits that include alluvial, marine, and mudflow deposits (Walters and Kimmel, 1968; Dragovich and others, 1994).

The study area has a temperate marine climate with warm, dry summers and cool, wet winters; the mean annual temperature is about $52^{\circ} \mathrm{F}$. The warmest month of the year is July, with an average temperature of about $63^{\circ} \mathrm{F}$, and the coolest month of the year is January, with an average temperature of about $38^{\circ} \mathrm{F}$ (National Oceanic and Atmospheric Administration, 1995 and 1996).

About 70 percent of the precipitation in the area occurs during the months of October through March, based on long-term data from the McMillin Reservoir and the Tacoma weather stations (1941 to 1996) (National Oceanic and Atmospheric Administration, 1996).

Although the seasonal distribution of precipitation is similar throughout the area, annual precipitation totals vary with altitude. Precipitation at the Tacoma weather station, altitude $25 \mathrm{ft}$, has averaged 37 inches a year, and at McMillin Reservoir, altitude $579 \mathrm{ft}$, it has averaged 42 inches a year (Daly and others, 1994; National Oceanic and Atmospheric Administration, 1996).

The area is transected by several creeks whose headwaters originate within the study area, and the area is bordered on the east by the Puyallup River, which originates at Mount Rainier in the Cascade Range. The creeks include Swan, Clear, and Clarks Creeks, which flow northward into the Puyallup River and out to Commencement Bay, and Clover and Chambers Creeks, which flow southwest into the Puget Sound (fig. 1).

Much of the area is urban, with most of the population concentrated in the cities. Seventy-three percent of the estimated 1996 population of 228,000 within the study area reside within the incorporated Cities of Puyallup and Tacoma (Puget Sound Regional Council, 1997). The population increased 5.6 percent from 1990 to 1996, with most of the growth occurring in the cities. Most of the water supplied to the area is from eight public-supply systems. About 97 percent of water use is for residential, commercial, and industrial purposes. About 3 percent of the water is used for agriculture, aquaculture, irrigation, and system losses. About 75 percent of the population in the study area are on municipal sewer systems.
The sewered areas include the Cities of Puyallup and Tacoma and a small portion of the unincorporated part of the study area. Treated water from Tacoma and the unincorporated part of the study area sewer systems is discharged into Commencement Bay, and treated water from the Puyallup sewer system is discharged into the Puyallup River.

\section{Well-Numbering System}

The USGS assigns numbers to wells and springs in Washington that identify their location in a township, range, and section. Well number 19N/03E-10P02 indicates, successively, the township (T. 19 N.) and range (R. 03 E.) north and east of the Willamette base line and meridian. The first number following the hyphen indicates the section (10) within the township, and the letter following the section number gives the 40-acre subdivision of the section, as shown below (fig. 2). The number (02) following the letter is the sequence number of the well within the 40 -acre subdivision. This number indicates that the well was the second one inventoried by the USGS personnel in that 40 -acre tract. An " $S$ " following the sequence number indicates that the site is a spring, a "D1" after the sequence number indicates that the original reported depth of the well has been changed once, and successive numbers indicate the number of changes in the well depth.

\section{Acknowledgments}

The authors wish to express their appreciation to the many well owners and well drillers who supplied well records and other information and allowed access to their wells. We also acknowledge the assistance and information supplied by managers and owners of the public watersupply systems and water districts; these include the Cities of Puyallup and Tacoma, the Summit Water and Supply Company, Fruitland Mutual Water Company, Firgrove Mutual Water Company, Parkland Light and Water Company, Southeast Tacoma Mutual Water Company, and Valley Water District. We express our appreciation to Lynn Gooding of the Washington Department of Ecology and Bryant Adams at Matsushita Semiconductor Corporation of America for information obtained for some sites. Numerous consulting firms working in cooperation with petroleum and industrial distributors were helpful by providing information and reports of their investigations. The petroleum and industrial distributors providing data and reports from their sites are the Atlantic Richfield Company (ARCO), British Petroleum (BP), Chevron Oil Company, Shell Oil Company, Texaco Oil Company, Union Oil 


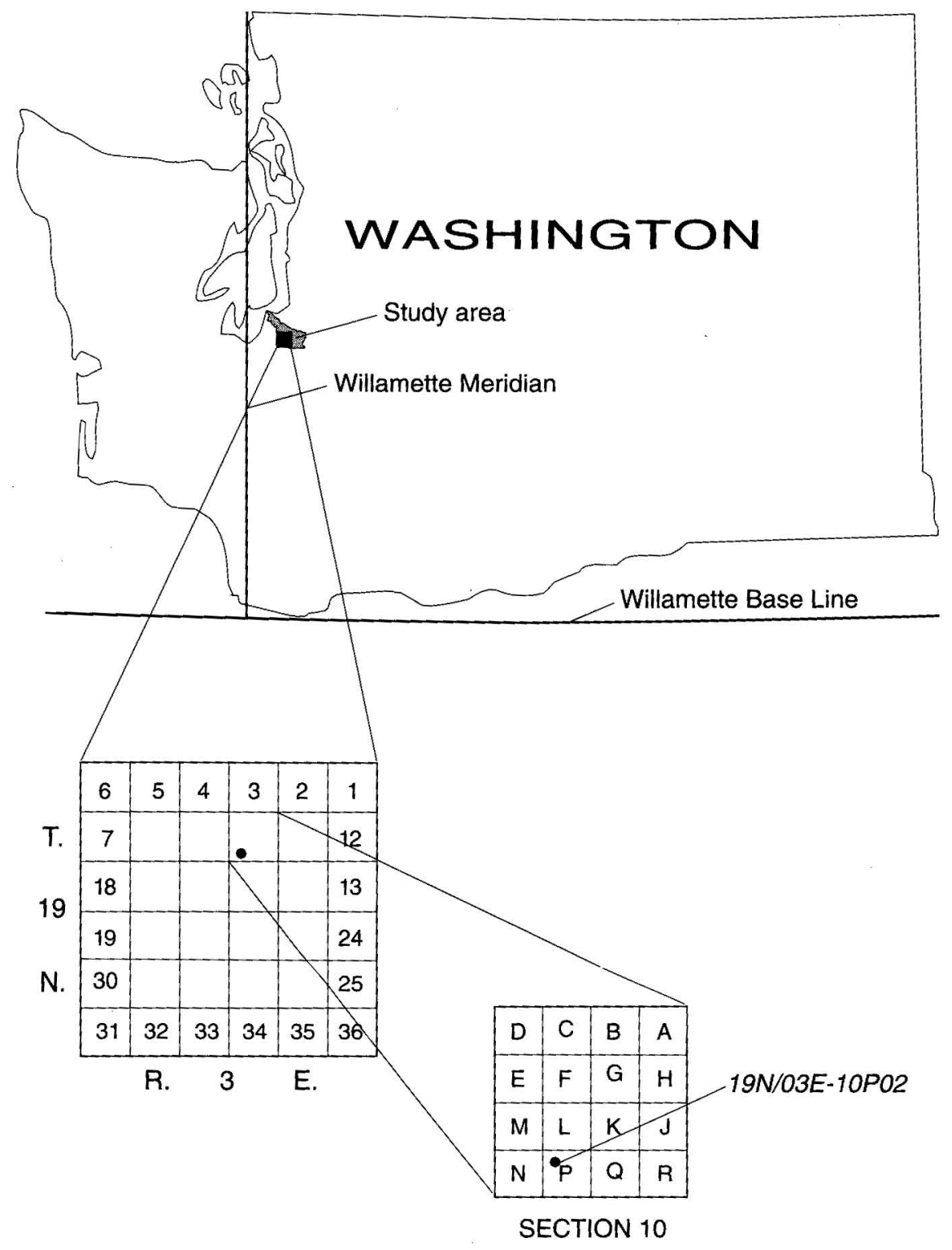

Figure 2. Well- and spring-numbering system used in Washington. 
Company (UNOCAL), and American Smelting and Refining Company (ASARCO). Consultants that provided information and reports from their investigations of these sites are K.V. Lew of Agra Earth and Environmental, Kurt Fraese of Geo-Engineers, Howard Small of Texaco Environmental Services, Gary Gunderson of UNOCAL, John Johnson of Pacific Environmental Group, Al Thatcher of Dames and Moore, and Rens Verburg of Hydrometrics, Inc. These individuals and firms provided information for sites within municipal boundaries where ground-water data are sparse.

\section{STUDY METHODS}

This study began with the compilation of existing spring, well, piezometer, test hole, and bridge boring records obtained from files of the USGS, Ecology, consulting firms, and well owners. Beginning in March of 1995, more than 1,750 records were reviewed; from these records 400 sites were selected for field inventory. The selection of wells to be inventoried was based on the well owner's or tenant's permission to visit the well, the location and depth of the well, the availability of a driller's log or equivalent, and the ease of access to the well. Priority was also given to wells previously inventoried by the USGS and wells that were open to only one hydrogeologic unit.

An attempt was made to inventory an even areal distribution of the wells within the study area. But this was not possible for the entire study area. Because of a lack of wells in the northwestern part of the study area, a few wells were inventoried in an adjacent area outside the study area. In many instances, only one or two wells in a given section were available to inventory, which limited the areal distribution. However, where several wells were available, field personnel inventoried the most readily accessible well. As a result, a well may have been inventoried simply because the owner was home.

The springs selected for inventory were primarily from the list of previously inventoried springs published in Walters and Kimmel (1968). A few additional springs identified by water purveyors and USGS field personnel were also inventoried.

During the summer of 1995,318 sites were inventoried by USGS field personnel; of these, 287 were wells and 31 were springs. Ten of the springs had been destroyed (fig. 3 and appendix 1). General information gathered at all inventoried sites included site location, land surface altitude, specific conductance and temperature (when available) of the water, primary use of water, owner's or tenant's comments on water quality and yield, surrounding land-use practices, and construction details of the site. Site locations were plotted on USGS 1:24,000scale topographic maps. Altitudes of the land surface at each well or spring were interpolated from the topographic maps with an accuracy of plus or minus $10 \mathrm{ft}$. Latitude and longitude locations were also estimated from the topographic maps with an accuracy of plus or minus 5 seconds (a few hundred feet). Randomly selected wells were cross checked using a satellite-based Global Positioning System (GPS) with a horizontal accuracy of 10 feet. Specific conductance and temperature measurements were determined for water samples from 129 wells and 18 springs with a field meter that was calibrated daily. Washington Department of Ecology identification tags were attached to 112 wells and 1 spring after obtaining the owner's permission. Information collected during the inventory was entered into the USGS National Water Information System (NWIS) data base.

In addition, the depth to water in the wells was measured when possible (appendix 1) using a graduated steel tape accurate to plus or minus $0.01 \mathrm{ft}$ or an electric tape accurate to $0.1 \mathrm{ft}$. The accuracy of the water-level altitudes (land surface altitude of the well minus depth to water) depends primarily on the accuracy of the land surface altitudes of the wells. The land surface altitudes were interpolated from topographic maps; thus the accuracy of the water-level altitude is plus or minus 10 feet.

At spring sites, discharge measurements and hydrogeologic unit identifications were made. Depending on the amount and location of the spring discharge, measurements were made with one or more of the following: a 3-inch Parshall flume (U.S. Geological Survey, 1983), a 5-gallon bucket and a stopwatch, a standard 90 degree V-Notched weir, or a standard rectangular weir. Discharge measurements at springs were made twice, once during the fall of 1995 and again in the spring of 1996 . Hydrogeologic unit assignments were made by noting the location and altitude of the spring and by examining the type and thickness of exposed geologic deposits above and below the spring.

A network of 36 inventoried wells was selected for bimonthly measurements of water level and, when possible, specific conductance and temperature to track seasonal water-level variations. Closely spaced wells, for example, 20N/03E-20P1 and 20N/03E-20P2, completed at different depths, $117 \mathrm{ft}$ and $254 \mathrm{ft}$, respectively, were selected to evaluate the vertical differences between the two aquifer units. Because data were sparse in 
the northwestern part of the study area, three wells (20N/02E-12M01, 20N/02E-12M02, and 20N/02E-12Q1) just outside the study area were selected for bimonthly visits. One of the bimonthly sites, well $19 \mathrm{~N} / 04 \mathrm{E}-03 \mathrm{~K} 02$, was destroyed 16 months after the inventory began.

\section{Hydrogeologic Methods}

Information from previous publications on the surficial geology (Walters and Kimmel, 1968), coastal and bluff outcrop geology (Washington Department of Ecology, 1979; Crandell and Mullineaux, 1965), and nearby lithologic sections (Brown and Caldwell, 1985) was used along with the driller's lithologic logs and information from field observations to approximately delineate the hydrogeologic units of the area. From the inventoried wells, 153 wells were used to construct 17 hydrogeologic sections trending north-south and east-west across the study area. From these 17 sections, 5 representative sections are presented in this report (see Hydrogeologic Framework). The 71 lithologic logs used to construct the 5 sections are provided in appendix 2. The sections were used to identify and correlate the continuity of aquifer and semiconfining hydrogeologic units in the study area. Starting at land surface and moving downward through the unconsolidated Quaternary deposits, each hydrogeologic unit was extrapolated laterally to the extent available data would allow. Generally, the thinner or deeper the hydrogeologic unit, the less certain is its correlation. Because the hydrogeologic units identified are a generalization of the lithologies based on their hydrologic properties, they do not necessarily represent time-stratigraphic geologic units.

Information from the sections, surficial geology, and the remaining 102 inventoried wells with drillers' logs that were not used in the construction of the 17 sections was then used to construct maps of the altitudes of the tops of the uppermost hydrogeologic units. These altitudes are listed in table 15 (at end of text). The tops of the units commonly reflect the trend of the surface topography. The thicknesses reported in the text are based on interpretations of these same inventoried wells. The surficial hydrogeologic map was constructed by combining similar lithologies of the surficial geologic map, interpretations from the sections, and information from the driller's lithologic logs.

Horizontal hydraulic conductivities were estimated based on pump or bail-test specific-capacity data reported in the drillers' logs. Information was available for 138 inventoried wells and 14 noninventoried wells in the study area (appendix 1). All wells used to estimate the hydraulic conductivity were open to one hydrogeologic unit, and all but 14 wells had complete specific-capacity information (discharge rate, drawdown, time, well-construction data, and a geologic log). The test duration at the 14 wells was not reported but was assumed to be 1 hour, which is typical for specific-capacity tests in the area (appendix 1). If the actual time for the specific-capacity test was longer, the hydraulic conductivity of the well would have been greater than the one calculated for these wells.

Two different methods were used to calculate the horizontal hydraulic conductivity. For those wells constructed with screened or perforated intervals, the modified Theis equation (Theis, 1963) for nonleaky artesian aquifers (Ferris and others, 1962) was first used to estimate test transmissivity values. This equation is

$$
T=\frac{Q}{4 \pi s} \ln \frac{2.25 T t}{r^{2} S}
$$

where

$T=$ transmissivity of the hydrogeologic unit, in $\mathrm{ft}^{2} / \mathrm{d}$ (square feet per day);

$Q=$ discharge, or pumping rate, of the well, in $\mathrm{ft}^{3} / \mathrm{d}$ (cubic feet per day);

$s=$ drawdown in the well, in feet;

$t=$ length of time the well was pumped, in minutes;

$r=$ effective radius of the well, in feet; and

$S=$ storage coefficient, a dimensionless decimal.

The modified Theis equation also requires an assumed value for the storage coefficient; a value of 0.0002 was used for wells in confined aquifers, and a value of 0.2 was used for wells in unconfined aquifers. The potential error to the calculated hydraulic conductivity is directly proportional to the error in the assumed storage coefficient value. In general this might amount to a factor of 2 or less. To then estimate an average hydraulic conductivity, the transmissivity value was divided by the length of open-interval of the well.

$$
K_{h}=T / b,
$$

where

$$
\begin{aligned}
K h= & \text { horizontal hydraulic conductivity of the } \\
& \text { hydrogeologic unit, in } \mathrm{ft} / \mathrm{d} ;
\end{aligned}
$$




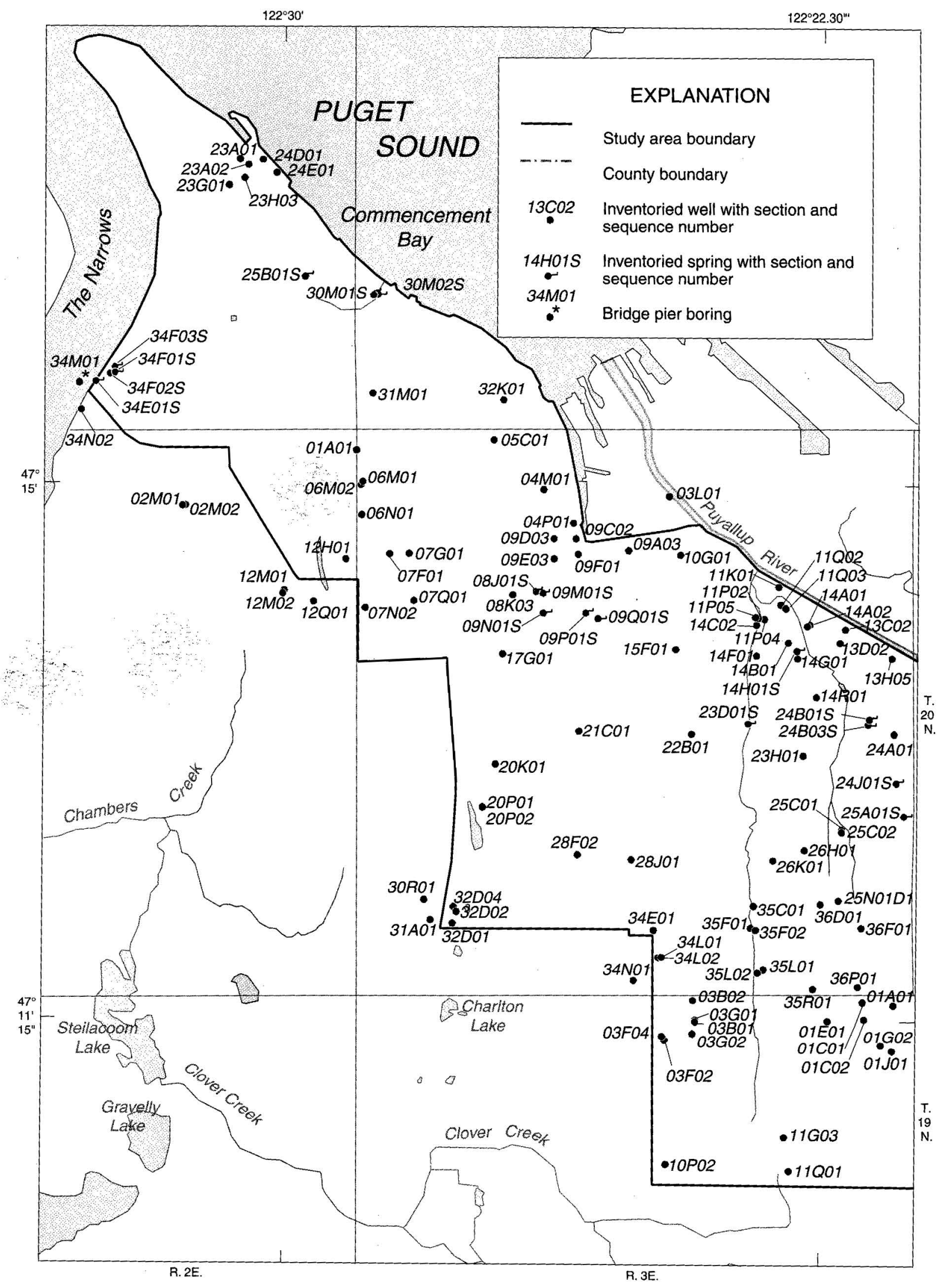

Figure 3. Locations of wells and springs inventoried in the Tacoma-Puyallup area, Washington. 


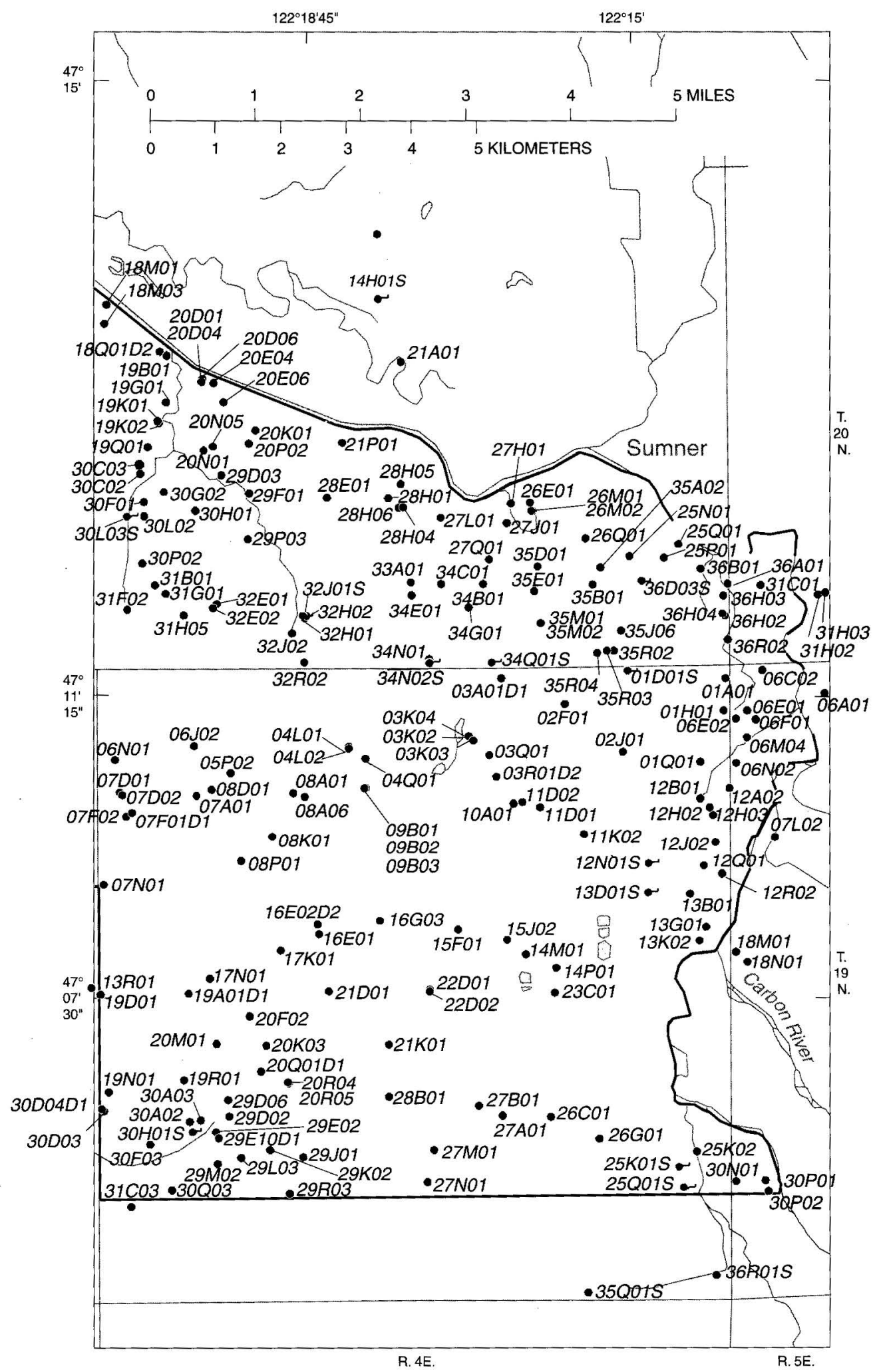


This method assumes that well entrance losses are negligible, that the well is screened across the full thickness of the aquifer, and that flow into the well is sustained by withdrawal from storage within the screened interval of the well. In reality some of the water flows vertically to the well from above and below the well screen. Even though neglecting the vertical flow conditions may result in an overestimation of the horizontal hydraulic conductivity and aquifer transmissivity, the amount of error is probably small because the layering within the hydrogeologic units tends to make horizontal flow easier than vertical flow.

For wells having only an open end and thus no vertical dimension to the open interval, Bear (1979) provides for an equation for hemispherical flow of a well just penetrating a hydrogeologic unit. When modified for spherical flow to an open-ended well within a unit, the equation to estimate the hydraulic conductivity becomes

$$
K_{h}=\frac{Q}{4 \pi s r}
$$

where

$$
\begin{aligned}
K h= & \text { horizontal hydraulic conductivity of the } \\
& \text { hydrogeologic unit, in } \mathrm{ft} / \mathrm{d} ; \\
Q= & \text { discharge, or pumping rate of the well, in } \mathrm{ft}^{3} / \mathrm{d} ; \\
s= & \text { drawdown in the well, in feet; and } \\
r= & \text { radius of the well, in feet. }
\end{aligned}
$$

This equation assumes that ground water can flow equally in all directions and specifically that horizontal and vertical hydraulic conductivities are equal. This is not likely to be true for aquifers in the study area, given their heterogenous nature. However, the errors associated with violating this assumption for open-ended wells are thought to be less than those resulting from using the modified Theis equation described above.

Ground-water recharge from precipitation was estimated based on the results obtained from a deeppercolation recharge model (Bauer and Vaccaro, 1987) completed in southwest King County, just northeast of the study area in similar lithologic deposits (Woodward and others, 1995). The regression equations from this model were used to create two curves based on precipitation, recharge, and lithology for a study completed in east King County (Turney and others, 1995). These two curves and more recent publications on recharge in till-mantled catchments by Bauer and Mastin (1997) were used to calculate the recharge for the study area. The equations and interpretation are discussed in greater detail in the section on recharge (Ground-Water Recharge).

\section{Water-Use Methods}

Water-use data for this study were determined for water year 1996 (October 1995 through September 1996). Most of the data collected were obtained by telephone canvassing of the major water users in the study area. Major categories of water use included metered and estimated pubic-supply systems, public-supply systems water loss, domestic, irrigation, agriculture, aquaculture, commercial, and industrial uses. Information on the water users in the study area was obtained from Ecology, Washington State Department of Health, available drillers' logs or equivalents, and information gathered from owners or water managers during field inventory. Because some water users may not have been contacted, all water-use totals represent minimum values. Selected water-use data collected from all sites included owner's name, mailing address, site location address, contact person, sources of water, actual or estimated ground-water withdrawal, and whether the ground-water withdrawal from the well or spring was metered. Depending on the use of the site, additional information was gathered that included the percent of commercial, industrial, water loss, and residential use, both permanent and seasonal; the amount of land irrigated; the types of crops grown; and the types and number of livestock using the water. The quantity of ground water withdrawn was then categorized by hydrogeologic unit based on the open-interval of the well.

Water-use estimates were made for all public-supply systems in the study area. Public water systems at the time of this study were divided into two classes, Group A and Group B, by the Washington Department of Health (Washington Department of Ecology, 1994). Group A systems are defined as having 15 or more connections and are subject to federal and state regulations. Group B water systems are defined as having 2 to 14 connections and are subject only to state and local regulations. Within the study area, 8 Group A and 12 Group B public-water systems were identified. Data available from six Group A systems and eight Group B systems were metered, and the actual ground-water withdrawal data were used. For the remaining two Group A and four Group B water systems, for which metered withdrawal values were unavailable, water managers provided estimates of the number of connections and average number of persons per connection. The withdrawal and population data from the metered systems were used to determine the average water use per person per day (93.5 gallons). This data and the information provided by the water managers were then entered into the following formula from which water-use estimates were made for the nonmetered systems. 
$W=C \times P \times 93.5$ gallons per

person per day $\mathrm{x} 366$ days

where

$W=$ estimated annual system withdrawal, in gallons;

$C=$ number of connections;

$P=$ average number of persons per connections;

93.5 gallons per person per day = per capita rate based on average water use per person per day for Group A and B metered systems; and 366 days = number of days in 1996 water year.

The average estimated water loss was 7 percent, based on information from the public-supply systems inventoried in the study area.

Annual ground-water withdrawals from privately owned wells and springs for domestic use were calculated by first determining the population of the study area whose homes were supplied by Group A or Group B publicsupply systems (172,000 people) and subtracting the number from the total population of the study area (228,000 people). The difference $(56,000)$ was then multiplied by 366 days and then by the per capita rate of $93.5 \mathrm{gal} / \mathrm{d}$ (gallons per day).

Ground-water withdrawals for irrigation, agriculture, and aquaculture activities were based on the operators' estimates. Information on water use for irrigated acreage and herd size were obtained by telephone and personal contact with farmers identified by USGS personnel during the well-inventory process. If estimates were unknown or uncertain, withdrawals were calculated by one of the following methods. For crop irrigation, one of two methods were used: (1) the pumping capacity of the irrigation well was multiplied by the owner's estimate of duration of pumping; or (2) an application rate of water specific to the crop being raised (W. R. Bidlake, U.S. Geological Survey, written commun., 1997; and James and others, 1988) was multiplied by the estimates of irrigated acreage per year (irrigation season). To determine agricultural and aquacultural consumption, the number of stock or fish was multiplied by the estimated daily consumption per animal and the number of days of consumption (U.S. Soil Conservation Service, 1975).

Water-use estimates for commercial and industrial use were supplied either by operators whose water supply was self-supplied from the company's privately owned well or by managers of public-supply systems who supply water for commercial and industrial use. It is unlikely, however, that all commercial and industrial wells in the study area were identified and inventoried during this study.

\section{Water-Quality Methods}

Water samples were collected from 33 sites, which included 29 wells and 4 springs, in late June and early July of 1996. Samples from all 33 sites were analyzed for concentrations of major ions, bacteria, arsenic, and nitrates. In addition, on-site measurements of carbonate, bicarbonate, alkalinity, temperature, specific conductance, $\mathrm{pH}$, and dissolved-oxygen concentrations were made at all sites. Subsets of the samples from 33 sites were analyzed for additional constituents. In urban areas where septic tank density was generally high, samples from 22 sites were analyzed for boron and methylene blue active substances (MBAS). Samples from 12 sites, generally springs and shallow wells (generally less than $100 \mathrm{ft}$ ), were analyzed for trace elements, which included arsenic, cadmium, chromium, copper, lead, mercury, selenium, silver, and zinc (table 1 and appendix 3 ). When a trace element analysis was performed, a separate analysis for arsenic was not done because arsenic is included in the trace element analysis. Another group of samples from 12 sites composed of springs and shallow wells was analyzed for volatile organic compounds (VOCs) (table 2). Samples from 12 sites, of generally shallow wells and springs, were analyzed for pesticides (table 3). Samples from 11 sites were analyzed for radon, and samples from 12 sites were analyzed for total organic carbon (TOC).

Many factors played a role in the selection of sampling sites and the analysis performed on these samples. Sampling sites were selected on the basis of surficial geology and land use, which included agriculture, forested, urban, and rural areas; of previous sampling of wells; of well location, whether in a sewered or nonsewered area; and of permission by the owner to sample. Because of the regional nature of this study, no attempt was made to sample sites affected by known small-scale or point source problems. However, an effort was made to sample sites that might be representative of widespread water-quality problems. Thus, areas of potential ground-water-quality problems, such as elevated nitrate, bacteria or the presence of pesticides, were considered in the site-selection process. An effort was also made to collect samples near large commercial or industrial areas for analysis of VOCs, TOCs, and trace metals. However, only two such wells could be found. 
Table 1.--Chemical Abstract Services registry number and minimum reporting level for selected major ions, trace elements, and other constituents in the Tacoma-Puyallup area, Washington

$[\mathrm{mg} / \mathrm{L}$, milligrams per liter; $\mu \mathrm{g} / \mathrm{L}$, micrograms per liter; $\mathrm{pCi} / \mathrm{L}$, picocuries per liter; col. $/ 100 \mathrm{~mL}$, colonies per 100 milliliters]

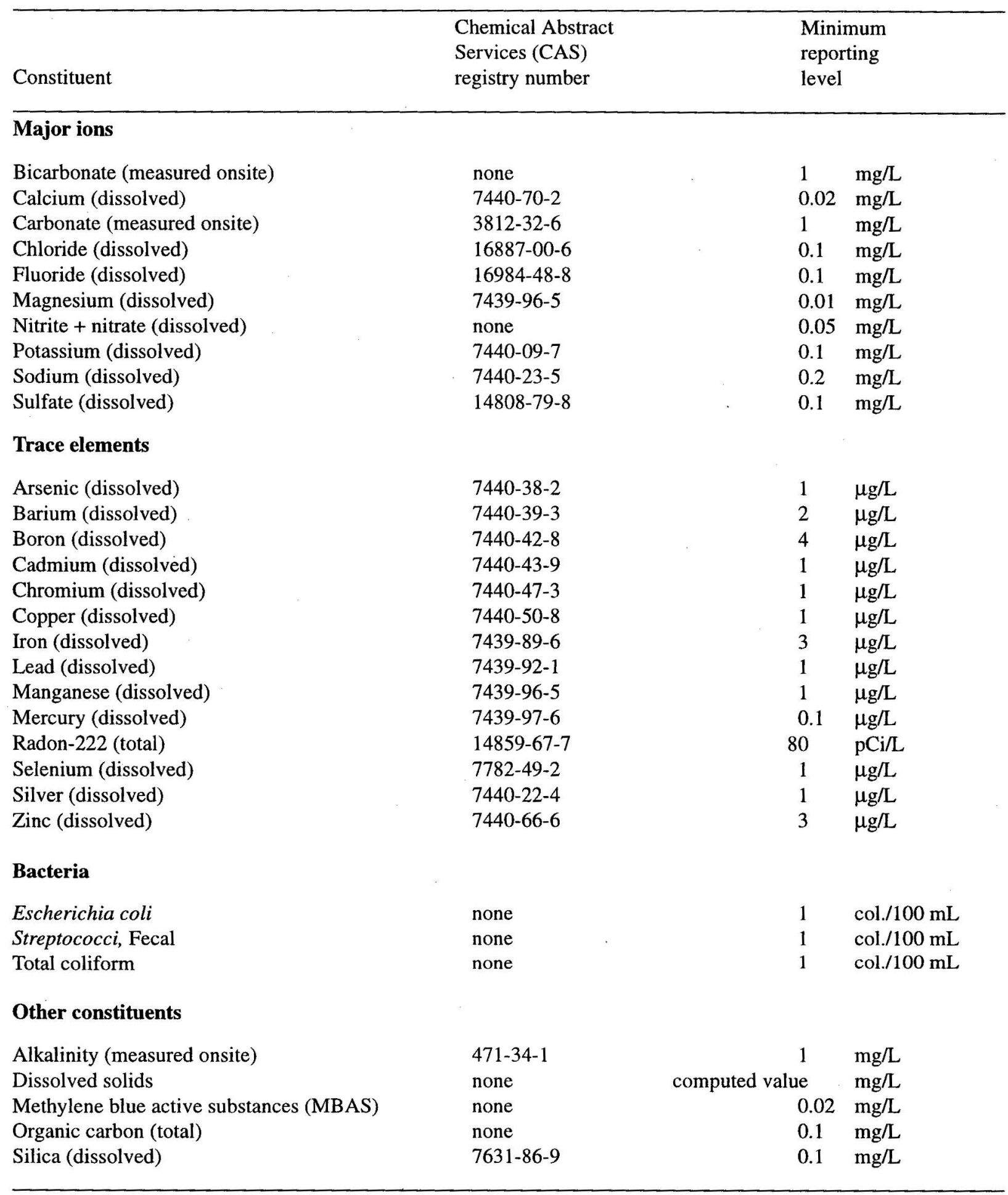


Table 2.--Volatile organic compound analyzed for, Chemical Abstract Services registry number, and minimum reporting level $[\mu \mathrm{g} / \mathrm{L}$, micrograms per liter]

\begin{tabular}{|c|c|c|}
\hline Volatile organic compounds & $\begin{array}{l}\text { Chemical Abstract } \\
\text { Services (CAS) } \\
\text { registry number }\end{array}$ & $\begin{array}{l}\text { Minimum } \\
\text { reporting } \\
\text { level }(\mu \mathrm{g} / \mathrm{L})\end{array}$ \\
\hline 1,1,1,2-Tetrachloroethane & $630-20-6$ & 0.2 \\
\hline 1,1,1-Trichloroethane & $71-55-6$ & 0.2 \\
\hline 1,1,2,2-Tetrachloroethane & $79-34-5$ & 0.2 \\
\hline 1,1,2-Trichloroethane & $79-00-5$ & 0.2 \\
\hline 1,1,2-Trichlorotrifluoroethane & $76-13-1$ & 0.2 \\
\hline 1,1-Dichloroethane & $75-34-3$ & 0.2 \\
\hline 1,1-Dichloroethene & $75-35-4$ & 0.2 \\
\hline 1,1-Dichloropropene & $563-58-6$ & 0.2 \\
\hline 1,2,3-Trichlorobenzene & $87-61-6$ & 0.2 \\
\hline 1,2,3-Trichloropropane & $96-18-4$ & 0.2 \\
\hline 1,2,4-Trichlorobenzene & $120-82-1$ & 0.2 \\
\hline 1,2,4-Trimethylbenzene & $95-63-6$ & 0.2 \\
\hline 1,2-Dibromo-3-chloropropane (DBCP) & $96-12-8$ & 1 \\
\hline 1,2-Dibromoethane (EDB) & $106-93-4$ & 0.2 \\
\hline 1,2-Dichlorobenzene (ortho) & $95-50-1$ & 0.2 \\
\hline 1,2-Dichloroethane & $107-06-2$ & 0.2 \\
\hline 1,2-Dichloropropane & $78-87-5$ & 0.2 \\
\hline 1,3,5-Trimethylbenzene & $108-67-8$ & 0.2 \\
\hline 1,3-Dichlorobenzene (meta) & $541-73-1$ & 0.2 \\
\hline 1,3-Dichloropropane & $142-28-9$ & 0.2 \\
\hline 1,4-Dichlorobenzene (para) & $106-46-7$ & 0.2 \\
\hline 2,2-Dichloropropane & $594-20-7$ & 0.2 \\
\hline 2-Chlorotoluene & $95-49-8$ & 0.2 \\
\hline 4-Chlorotoluene & $106-43-4$ & 0.2 \\
\hline Benzene & $71-43-2$ & 0.2 \\
\hline Bromobenzene & $108-86-1$ & 0.2 \\
\hline Bromochloromethane & $74-97-5$ & 0.2 \\
\hline Bromodichloromethane & $75-27-4$ & 0.2 \\
\hline Bromoform & $75-25-2$ & 0.2 \\
\hline Bromomethane & $74-83-9$ & 0.2 \\
\hline n-Butylbenzene & $104-51-8$ & 0.2 \\
\hline Carbon tetrachloride & $56-23-5$ & 0.2 \\
\hline Chlorobenzene & $108-90-7$ & 0.2 \\
\hline Chloroethane & $75-00-3$ & 0.2 \\
\hline Chloroform & $67-66-3$ & 0.2 \\
\hline Chloromethane & $74-87-3$ & 0.2 \\
\hline Chlorodibromethane & $124-48-1$ & 0.2 \\
\hline
\end{tabular}


Table 2.--Volatile organic compound analyzed for, Chemical Abstract Services registry number, and minimum reporting level--Continued

\begin{tabular}{lll}
\hline Volatile organic compounds & $\begin{array}{l}\text { Chemical Abstract } \\
\text { Services (CAS) } \\
\text { registry number }\end{array}$ & $\begin{array}{l}\text { Minimum } \\
\text { reporting } \\
\text { level }(\mu \mathrm{g} / \mathrm{L})\end{array}$ \\
\hline Dichlorodifluoromethane (CFC 12) & $75-71-8$ & 0.2 \\
Ethylbenzene & $100-41-4$ & 0.2 \\
Hexachlorobutadiene & $87-68-3$ & 0.2 \\
Isopropylbenzene & $98-82-8$ & 0.2 \\
Methylene chloride & $75-09-2$ & 0.2 \\
Methyl tert-butyl ether (MTBE) & $1634-04-4$ & 0.2 \\
Naphthalene & $91-20-3$ & 0.2 \\
$n$-Propylbenzene & $103-65-1$ & 0.2 \\
$p$-Isopropyltoluene & $99-87-6$ & 0.2 \\
Styrene (total) & $100-42-5$ & 0.2 \\
Tetrachloroethene & $127-18-4$ & 0.2 \\
Toluene & $108-88-3$ & 0.2 \\
Trichloroethene & $79-01-6$ & 0.2 \\
Trichlorofluoromethane (CFC 11) & $75-69-4$ & 0.2 \\
Vinyl chloride & $75-01-4$ & 0.2 \\
Xylenes (total) & $1330-20-7$ & 0.2 \\
cis-1,2-Dichloroethene & $156-59-2$ & 0.2 \\
cis-1,3-Dichloropropene & $10061-01-5$ & 0.2 \\
sec-Butylbenzene & $135-98-8$ & 0.2 \\
tert-Butylbenzene & $98-06-6$ & 0.2 \\
trans-1,2-Dichloroethene & $156-60-5$ & 0.2 \\
trans-1,3-Dichloropropene & $10061-02-6$ & 0.2 \\
& & \\
\hline
\end{tabular}


Table 3.--Pesticide target analytes, Chemical Abstract Services registry number, method detection limits, and drinking water standards

$[\mu \mathrm{g} / \mathrm{L}$, micrograms per liter; $\mathrm{H}$, herbicide; I, insecticide; $\mathrm{M}$, metabolite; F, fungicide; --, no data; drinking water standards are U.S. Environmental Protection Agency (USEPA) maximum contaminant levels for drinking water from USEPA (1996), unless otherwise footnoted]

\begin{tabular}{llllll}
\hline & & & Chemical & & Drinking \\
& Trade & Type & Abstract & Method & water \\
& or & of & Services & detection & standard or \\
$\begin{array}{l}\text { Pesticide } \\
\text { target analyte }\end{array}$ & common & pesti- & registry & limit & guideline \\
& name(s) & cide & number & $(\mu \mathrm{g} / \mathrm{L})$ & $(\mu \mathrm{g} / \mathrm{L})$ \\
\hline
\end{tabular}

Analyzed by Gas Chromatography/Mass Spectrometry

\begin{tabular}{|c|c|c|c|c|c|}
\hline Acetochlor & Surpass & $\mathrm{H}$ & $34256-82-1$ & 0.002 & -- \\
\hline Alachlor & Lasso & $\mathrm{H}$ & $15972-60-8$ & 0.002 & 2 \\
\hline Atrazine & AAtrex & $\mathrm{H}$ & $1912-24-9$ & 0.001 & 3 \\
\hline Azinphos-methyl ${ }^{1}$ & Guthion & I & $86-50-0$ & 0.001 & -- \\
\hline Benfluralin & Balan, Benefin & $\mathrm{H}$ & $1861-40-1$ & 0.002 & - \\
\hline Butylate & Sutan + , Genate Plus & $\mathrm{H}$ & $2008-41-5$ & 0.002 & ${ }^{2} 350$ \\
\hline Carbaryl $^{1,3}$ & Sevin, Savit & I & $63-25-2$ & 0.003 & ${ }^{2} 700$ \\
\hline Carbofuran ${ }^{1,3}$ & Furadan & I & $1563-66-2$ & 0.003 & 40 \\
\hline Chlorpyrifos & Lorsban & I & $2921-88-2$ & 0.004 & ${ }^{2} 20$ \\
\hline Cyanazine & Bladex & $\mathrm{H}$ & $21725-46-2$ & 0.004 & ${ }^{2} 1$ \\
\hline DCPA & Dacthal & $\mathrm{H}$ & $1861-32-1$ & 0.002 & ${ }^{2} 4,000$ \\
\hline$p, p^{\prime}-\mathrm{DDE}$ & none & $\mathbf{M}$ & $72-55-9$ & 0.006 & ${ }^{4} 0.1$ \\
\hline Desethylatrazine $^{1}$ & none & M & $6190-65-4$ & 0.002 & -- \\
\hline Diazinon & several & I & $333-41-5$ & 0.002 & ${ }^{2} 0.6$ \\
\hline Dieldrin & Panoram D-31 & I & $60-57-1$ & 0.001 & ${ }^{4} 0.002$ \\
\hline 2,6-Diethylanaline & none & M & $579-66-8$ & 0.003 & -- \\
\hline Dimethoate $^{5}$ & Cygon & $\mathrm{I}$ & $60-51-5$ & 0.004 & -- \\
\hline Disulfoton & Di-Syston & I & $298-04-4$ & 0.017 & ${ }^{2} 0.3$ \\
\hline EPTC & Eptam, Eradicane & $\mathrm{H}$ & $759-94-4$ & 0.002 & - \\
\hline Ethalfluralin & Sonalan, Curbit EC & $\mathrm{H}$ & $55283-68-6$ & 0.004 & -- \\
\hline Ethoprop & Mocap & I & $13194-48-4$ & 0.003 & -- \\
\hline Fonofos & Dyfonate & I & $944-22-9$ & 0.003 & ${ }^{2} 10$ \\
\hline alpha-HCH & none & $\mathrm{M}$ & $319-84-6$ & 0.002 & ${ }^{4} 0.006$ \\
\hline gamma-HCH & Lindane & I & $58-89-9$ & 0.004 & 0.2 \\
\hline Linuron $^{3}$ & Lorox, Linex & $\mathrm{H}$ & $330-55-2$ & 0.002 & - \\
\hline Malathion & several & I & $121-75-5$ & 0.005 & ${ }^{2} 200$ \\
\hline Methyl parathion & Penncap-M & $\mathrm{I}$ & $298-00-0$ & 0.006 & 22 \\
\hline Metolachlor & Dual, Pennant & $\mathrm{H}$ & $51218-45-2$ & 0.002 & ${ }^{2} 100$ \\
\hline Metribuzin & Lexone, Sencor & $\mathrm{H}$ & $21087-64-9$ & 0.004 & ${ }^{2} 100$ \\
\hline Molinate & Ordram & $\mathrm{H}$ & $2212-67-1$ & 0.004 & -- \\
\hline Napropamide & Devrinol & $\mathrm{H}$ & $15299-99-7$ & 0.003 & -- \\
\hline Parathion & several & I & $56-38-2$ & 0.004 & - \\
\hline Pebulate & Tillam & $\mathrm{H}$ & $1114-71-2$ & 0.004 & -- \\
\hline Pendimethalin & Prowl,Stomp & $\mathrm{H}$ & $40487-42-1$ & 0.004 & -- \\
\hline cis-Permethrin & Ambush, Pounce & I & $57608-04-5$ & 0.005 & -- \\
\hline Phorate & Thimet, Rampart & I & $298-02-2$ & 0.002 & -- \\
\hline Prometon & Pramitol & $\mathrm{H}$ & $1610-18-0$ & 0.018 & ${ }^{2} 100$ \\
\hline
\end{tabular}


Table 3.--Pesticide target analytes, Chemical Abstract Services registry number, method detection limits, and drinking water standards--Continued

\begin{tabular}{|c|c|c|c|c|c|}
\hline $\begin{array}{l}\text { Pesticide } \\
\text { target analyte }\end{array}$ & $\begin{array}{l}\text { Trade } \\
\text { or } \\
\text { common } \\
\text { name(s) }\end{array}$ & $\begin{array}{l}\text { Type } \\
\text { of } \\
\text { pesti- } \\
\text { cide }\end{array}$ & $\begin{array}{l}\text { Chemical } \\
\text { Abstract } \\
\text { Services } \\
\text { registry } \\
\text { number }\end{array}$ & $\begin{array}{l}\text { Method } \\
\text { detection } \\
\text { limit } \\
(\mu \mathrm{g} / \mathrm{L})\end{array}$ & $\begin{array}{l}\text { Drinking } \\
\text { water } \\
\text { standard or } \\
\text { guideline } \\
(\mu \mathrm{g} / \mathrm{L})\end{array}$ \\
\hline
\end{tabular}

Analyzed by Gas Chromatography/Mass Spectrometry--Continued

$\begin{array}{lllllr}\text { Pronamide } & \text { Kerb } & \text { H } & 23950-58-5 & 0.003 & 250 \\ \text { Propachlor } & \text { Ramrod } & \text { H } & 1918-16-7 & 0.007 & 290 \\ \text { Propanil } & \text { Stampede } & \text { H } & 709-98-8 & 0.004 & -- \\ \text { Propargite } & \text { Comite, Omite } & \text { I } & 2312-35-8 & 0.013 & - \\ \text { Simazine } & \text { Aquazine, Princep } & \text { H } & 122-34-9 & 0.005 & 4 \\ \text { Tebuthiuron } & \text { Spike } & \text { H } & 34014-18-1 & 0.01 & 2500 \\ \text { Terbacil }^{1} & \text { Sinbar } & \text { H } & 5902-51-2 & 0.007 & 290 \\ \text { Terbufos } & \text { Counter } & \text { I } & 13071-79-9 & 0.013 & { }^{2} 0.9 \\ \text { Thiobencarb } & \text { Bolero } & \text { H } & 28249-77-6 & 0.002 & -- \\ \text { Triallate } & \text { Far-Go } & \text { H } & 2303-17-5 & 0.001 & - \\ \text { Trifluralin } & \text { Treflan, Trilin } & \text { H } & 1582-09-8 & 0.002 & 25\end{array}$

\begin{tabular}{|c|c|c|c|c|c|}
\hline $\begin{array}{l}\text { Pesticide } \\
\text { target analyte }\end{array}$ & $\begin{array}{l}\text { Trade } \\
\text { or } \\
\text { common } \\
\text { name(s) }\end{array}$ & $\begin{array}{l}\text { Type } \\
\text { of } \\
\text { pesti- } \\
\text { cide }\end{array}$ & $\begin{array}{l}\text { Chemical } \\
\text { Abstract } \\
\text { Services } \\
\text { registry } \\
\text { number }\end{array}$ & $\begin{array}{l}\text { Reporting } \\
\text { level } \\
(\mu \mathrm{g} / \mathrm{L})\end{array}$ & $\begin{array}{l}\text { Drinking } \\
\text { water } \\
\text { standard or } \\
\text { guideline } \\
(\mu \mathrm{g} / \mathrm{L})\end{array}$ \\
\hline
\end{tabular}

Analyzed by High-Performance Liquid Chromatography

\begin{tabular}{|c|c|c|c|c|c|}
\hline 2,4-D & several & $\mathrm{H}$ & $94-75-7$ & 0.15 & 70 \\
\hline 2,4-DB & none & I & $94-82-6$ & 0.24 & - \\
\hline $2,4,5-\mathrm{T}$ & several & $\mathrm{H}$ & $93-76-5$ & 0.035 & ${ }^{2} 70$ \\
\hline $2,4-5-\mathrm{TP}^{7}$ & Silvex & $\mathrm{H}$ & $93-72-1$ & 0.021 & 50 \\
\hline $\begin{array}{l}\text { 3-Hydroxy- } \\
\text { carbofuran }\end{array}$ & none & $\mathrm{M}$ & $1563-38-8$ & 0.014 & -- \\
\hline Acifluorfen & Blazer & $\mathrm{H}$ & $50594-66-6$ & 0.035 & ${ }^{4} 1$ \\
\hline Aldicarb $^{6,7}$ & Temik & I & $116-06-3$ & 0.55 & 7 \\
\hline Aldicarb sulfone $e^{6,7}$ & Standak & M & $1646-88-4$ & 0.10 & 7 \\
\hline Aldicarb sulfoxide ${ }^{6}$ & none & $\mathbf{M}$ & $1646-87-3$ & 0.021 & 7 \\
\hline Bentazon & Basagran & $\mathrm{H}$ & $25057-89-0$ & 0.014 & ${ }^{2} 20$ \\
\hline Bromacil & Hyvar, Urox B & $\mathrm{H}$ & $314-40-9$ & 0.035 & 290 \\
\hline Bromoxynil & Buctril, Brominal & $\mathrm{H}$ & $1689-84-5$ & 0.035 & -- \\
\hline Carbaryl $^{3,7}$ & Sevin, Savit & I & $63-25-2$ & 0.008 & ${ }^{2} 700$ \\
\hline Carbofuran $^{3,7}$ & Furadan & I & $1563-66-2$ & 0.12 & 40 \\
\hline Chloramben & Amiben, Vegiben & $\mathrm{H}$ & $133-90-4$ & 0.42 & ${ }^{2} 100$ \\
\hline Chlorothalonil $^{6}$ & Bravo & $\mathrm{F}$ & $1897-45-6$ & 0.48 & ${ }^{4} 1.5$ \\
\hline Clopyralid & Stinger, Lontrel & $\mathrm{H}$ & $1702-17-6$ & 0.23 & -- \\
\hline
\end{tabular}


Table 3.--Pesticide target analytes, Chemical Abstract Services registry number, method detection limits, and drinking water standards--Continued

\begin{tabular}{|c|c|c|c|c|c|}
\hline $\begin{array}{l}\text { Pesticide } \\
\text { target analyte }\end{array}$ & $\begin{array}{l}\text { Trade } \\
\text { or } \\
\text { common } \\
\text { name(s) }\end{array}$ & $\begin{array}{l}\text { Type } \\
\text { of } \\
\text { pesti- } \\
\text { cide }\end{array}$ & $\begin{array}{l}\text { Chemical } \\
\text { Abstract } \\
\text { Services } \\
\text { registry } \\
\text { number }\end{array}$ & $\begin{array}{l}\text { Reporting } \\
\text { level } \\
(\mu \mathrm{g} / \mathrm{L})\end{array}$ & $\begin{array}{l}\text { Drinking } \\
\text { water } \\
\text { standard or } \\
\text { guideline } \\
(\mu \mathrm{g} / \mathrm{L})\end{array}$ \\
\hline
\end{tabular}

Analyzed by High-Performance Liquid Chromatography--Continued

Dacthal,

mono-acid)

Dicamba

Dichlobenil $^{6}$

Dichlorprop

Dinoseb

Diuron

DNOC $^{6}$

Fenuron

Fluometuron

Linuron $^{3}$

MCPA

MCPB

Methiocarb ${ }^{7}$

Methomyl

Neburon

Norflurazon

Oryzalin

Oxamyl $^{7}$

Picloram ${ }^{7}$

Propham

Propoxur

Triclopyr $^{7}$

none
Banvel
Barrier, Casoron
2,4-DP, Seritox 50
DNBP, Dinitro
Karmex, Direx
Trifocide, Elgetol 30
Beet-Kleen
Flo-Met, Cotoran
Lorox, Linex
Metaxon, Kilsem
Can-Trol, Thistrol
Grandslam, Mesurol
Lannate, Nudrin
Neburex, Noruben
Evital, Solicam
Surflan
Vydate
Tordon
Chem-Hoe, IPC
Baygon
Garlon, Grazon

$\begin{array}{ll}\text { M } & 887-54-7 \\ \mathrm{H} & 1918-00-9 \\ \mathrm{H} & 1194-65-6 \\ \mathrm{H} & 120-36-5 \\ \mathrm{H} & 88-85-7 \\ \mathrm{H} & 330-54-1 \\ \mathrm{I}, \mathrm{F}, \mathrm{H} & 534-52-1 \\ \mathrm{H} & 101-42-8 \\ \mathrm{H} & 2164-17-2 \\ \mathrm{H} & 330-55-2 \\ \mathrm{H} & 94-74-6 \\ \mathrm{H} & 94-81-5 \\ \mathrm{I} & 2032-65-7 \\ \mathrm{I} & 16752-77-5 \\ \mathrm{H} & 555-37-3 \\ \mathrm{H} & 27314-13-2 \\ \mathrm{H} & 19044-88-3 \\ \mathrm{I} & 23135-22-0 \\ \mathrm{H} & 1918-02-1 \\ \mathrm{H} & 122-42-9 \\ \mathrm{I} & 114-26-1 \\ \mathrm{H} & 55335-06-3\end{array}$

$\begin{array}{lr}0.017 & -- \\ 0.035 & { }^{2} 200 \\ 1.2 & -- \\ 0.032 & -- \\ 0.035 & 7 \\ 0.02 & { }^{2} 10 \\ 0.42 & -- \\ 0.013 & - \\ 0.035 & 290 \\ 0.018 & - \\ 0.17 & 210 \\ 0.14 & - \\ 0.026 & - \\ 0.017 & 200 \\ 0.015 & - \\ 0.024 & - \\ 0.31 & - \\ 0.018 & 200 \\ 0.05 & 500 \\ 0.035 & 2100 \\ 0.035 & -- \\ 0.25 & -\end{array}$

${ }^{1}$ Concentrations for these pesticides are qualitatively identified and reported with an E code (estimated value) because of problems with gas chromatography or extraction (Zaugg and others, 1995).

${ }^{2}$ U.S. Environmental Protection Agency lifetime-health advisory for a 70-kilogram adult, from Nowell and Resek (1994).

${ }^{3}$ Analyzed by both gas chromatography/mass spectrometry and high-performance liquid chromatography methods.

${ }^{4}$ U.S. Environmental Protection Agency risk-specific dose health advisory associated with a cancer risk of $10^{-6}$ (one in a million), from Nowell and Resek (1994).

${ }^{5}$ Pesticide demonstrated small and variable recovery and was removed from the method schedule in November 1994. All data for dimethoate were removed from the data base in July 1996.

${ }^{6}$ The concentration values for these analytes are qualitatively identified and reported with an $\mathrm{E}$ code because of poor overall recovery and precision (NAWQA/NWQL Quality Assurance Committee for the Schedule 2050/2051

Pesticide Analysis Method, written commun., 1995).

${ }^{7}$ Pesticide target analyte is heat and light sensitive and therefore susceptible to degradation. This may result in poor overall recovery and precision (NAWQA/NWQL Quality Assurance Committee for the Schedule 2050/2051

Pesticide Analysis Method, written commun., 1995). 
The plumbing and construction characteristics of a well were also considered in the selection of sites to be sampled and in determining the type of samples that could be taken. Where possible, sites with submersible pumps were selected over those with turbine or centrifugal pumps. Samples taken from sites with centrifugal pumps were not analyzed for VOC compounds. The groundwater sampling system was connected to the well or spring distribution system as close to the wellhead or spring as possible. All samples were collected before they were treated by chlorination, fluoridation, or softening. Where possible, samples were collected before they entered any holding tank or copper plumbing. Samples for trace elements were not taken at sites where they encountered any copper before they reached the sampling point.

In a mobile water-quality laboratory, all samples were collected and prepared using USGS protocols. Sample water flowed from the hose bib through teflon tubing to a flow-directing stainless-steel manifold that allowed the sample water to flow into either a flow chamber, raw-water line, or filtration unit (fig. 4). Selected constituents and properties that included temperature, $\mathrm{pH}$, specific conductance, and dissolved-oxygen concentrations were monitored continuously at the flow chamber. Once the constituent's readings stabilized, filtered and unfiltered samples were collected from the appropriate manifold outlet (fig. 4). Temperature and raw samples to be analyzed for concentrations of bacteria were collected last directly from the hose bib.

Based on the constituent, sample analysis occurred at one of three locations: on-site; at the USGS Washington District laboratory in Tacoma, Wash., or at the USGS National Water Quality Laboratory (NWQL) in Arvada, Colo. Temperature, $\mathrm{pH}$, specific conductance, and alkalinity were measured on-site with meters using methods outlined by Wood (1981) and Fishman and Friedman (1989). Dissolved-oxygen concentrations were also determined on-site with a meter, but concentrations of $1.0 \mathrm{mg} / \mathrm{L}$ (milligram per liter) or less were verified on-site using the Rhodazine-D method (White and Others, 1990). Bacteria samples were analyzed for concentrations of fecal streptococci, total coliform, and Escherichia coli at the USGS Washington District laboratory in Tacoma. Fecal streptococci were analyzed using the KF Streptococcus agar method (Myers and Wilde, 1997). Analyses of both total coliform and Escherichia coli were performed using the membrane filter procedure with M-endo media as outlined by the Environmental Protection Agency (EPA) office of water (U.S. Environmental Protection Agency, 1991). Analysis of Escherichia coli was also conducted using NA-mug media (U.S. Environmental Protection Agency,
1991). Except for the bacteria analysis, all laboratory analyses were done by the USGS NWQL in Arvada, Colorado. Analytical procedures used at the NWQL are described by Fishman and Friedman (1989) and Wershaw and others (1987).

As part of the study's quality-assurance program, measurement instruments were calibrated daily, and sampling equipment was cleaned before the collection of each sample. The accuracy of the on-site measurements of $\mathrm{pH}$, specific conductance, and alkalinity was ensured by daily calibration of the meters with known standards. Dissolved-oxygen meters were also calibrated daily using the water-saturated air technique (Wood, 1981). The manifold and sampling lines were cleaned by flushing with a 0.02 percent solution of phosphate-free detergent and deionized water. Before a sample was collected, the manifold was flushed with sample water and new filters were flushed according to inorganic protocol (Horowitz and others, 1994). Except for bacteria, VOC compounds, radon, or pesticides sampling, all containers were rinsed prior to sampling with sample water.

In accordance with the project's quality-assurance plan, an equipment blank, duplicate samples, and field blanks were collected at some sampling sites. Duplicate samples for analysis by the NWQL were collected on a random basis. One duplicate sample was collected for every 7 sites sampled for MBAS and boron, 1 duplicate sample was collected for every 12 sites sampled for nitrate, and 1 duplicate sample was collected for every 6 sites sampled for radon. Blank samples of deionized water were also collected on a random basis. Three field blanks were collected for 32 sites sampled for major ions and nitrates. One field blank was collected for every 12 sites sampled for trace metals and pesticides. One field blank was collected for every 22 sites sampled for boron and MBAS. Duplicate samples and blanks of deionized water were processed in the same manner as ordinary groundwater samples and were submitted to the laboratory as ground-water samples.

Duplicate bacteria samples from randomly selected sites were analyzed at the USGS laboratory in Tacoma, Wash., each day of sampling in accordance with the project's quality-assurance plan.

Standard quality-assurance procedures were used at the NWQL. The resulting data were reviewed by laboratory personnel, then released to the local USGS District office in Tacoma, Wash., by electronic data transfer. The laboratory data were reviewed further by district and project personnel, and computer programs and statistical 


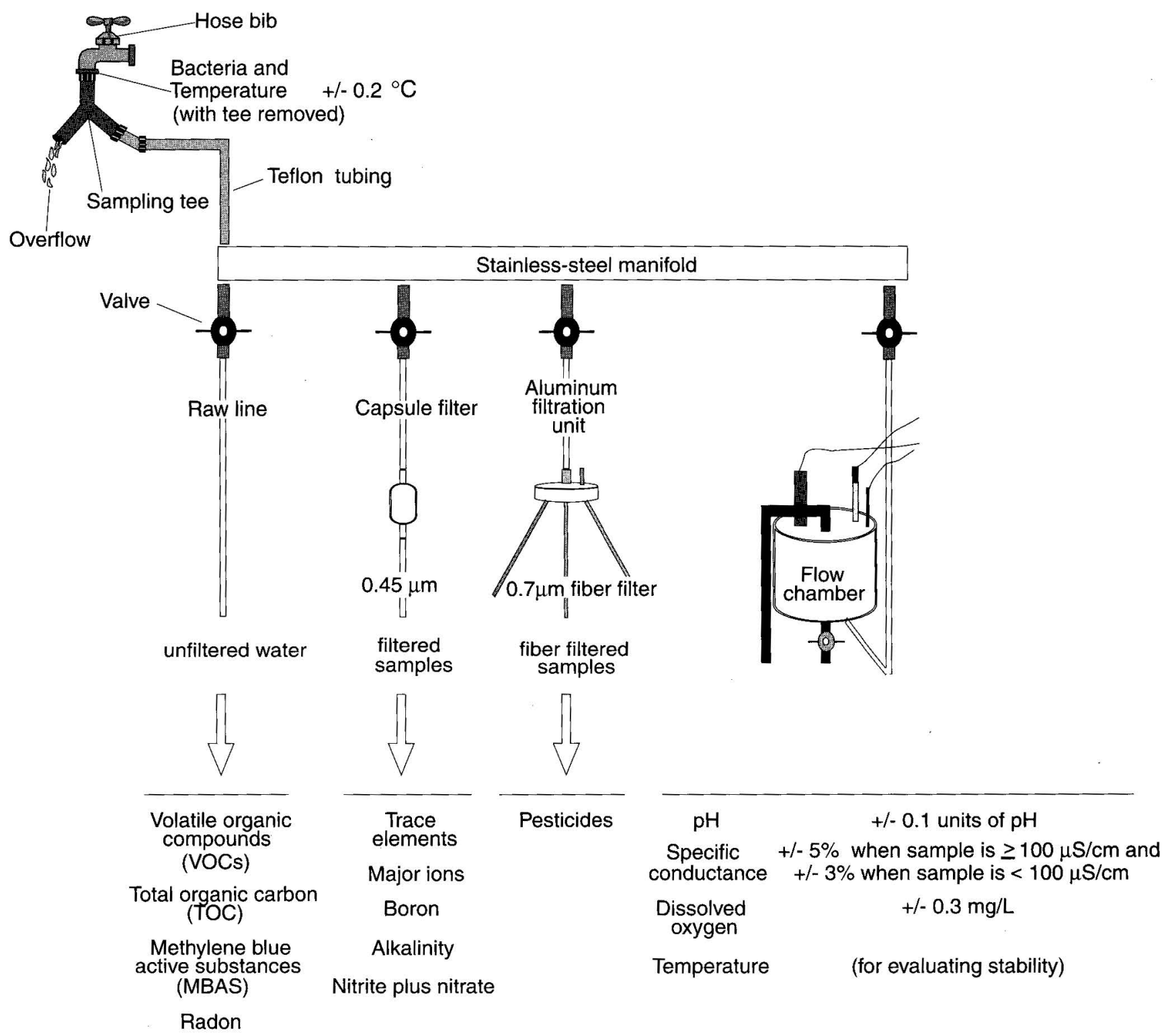

Figure 4. Ground-water sampling system and equipment precision. $\left({ }^{\circ} \mathrm{C}\right.$, degree Celsius; $\mu \mathrm{S} / \mathrm{cm}$, microsiemens per centimeter; $\mathrm{mg} / \mathrm{L}$, milligrams per liter; $\mu \mathrm{m}$, micrometer) 
techniques assisted in all stages of the reviews. The results of the water-quality analyses were stored in the USGS ground-water data base in Tacoma and uploaded into STORET (Storage and Retrieval of U.S. Waterways Parametric Data), the computerized water-quality data base of the EPA. Additional details of laboratory quality-assurance procedures and data review are discussed in the project quality-assurance plan (M. A. Jones, U.S. Geological Survey, written commun., July 25, 1995) and in the analytical methods outlined by Fishman and Friedman (1989) and in the organic analytical methods outlined by Wershaw and others (1987).

\section{HYDROGEOLOGIC FRAMEWORK}

This section describes the hydrogeologic framework, which defines the physical, lithologic, and hydrologic characteristics of the hydrogeologic units that compose the ground-water system in the study area. An understanding of these characteristics is important in determining the occurrence and availability of ground water.

The principal hydrogeologic units in the study area are composed of the unconsolidated Quaternary deposits. The lateral extent of these units was governed by the extent of the four glacial advances and retreats during the Pleistocene and by the younger alluvial and mudflow deposits of the Holocene (Crandell and others, 1958; and Walters and Kimmel, 1968). These deposits tend to be heterogenous and may be discontinuous in places. The thickness of the unconsolidated Quaternary deposits within the study area ranges from less than $600 \mathrm{ft}$ in the southeast corner to more than $1,800 \mathrm{ft}$ in the central part (fig. 5). Most of the available thickness data are from drillers' well logs and some oil-and-gas exploration wells (Buchanan-Banks and Collins, 1994). The median depth of wells within the study area is $160 \mathrm{ft}$ below the land surface, with only a few wells at depths greater than $700 \mathrm{ft}$ below the land surface. Most of the inventoried wells tap ground-water aquifers between $200 \mathrm{ft}$ above sea level and $200 \mathrm{ft}$ below sea level. A few wells tap aquifers at depths greater than $500 \mathrm{ft}$ below sea level. The maximum thickness of the unconsolidated deposits within the study area is probably greater than shown on figure 5 because of the scarcity of wells that penetrate to bedrock and the lack of available marine-seismic data (Jones, 1996).

A knowledge of the geologic structure in the study area may also assist in mapping the unconsolidated hydrogeologic units. The structural setting may help explain the depositional sequences, thickness variations, and segmentation of the ground-water movement systems or anomalous water-level distributions within the area. For example, a predominantly clay unit could be vertically offset and juxtaposed with a sand unit, thereby truncating lateral ground-water movement along a fault and also offsetting the water-level distribution on either side of the fault. Although these types of questions may not be answered in this study, the structural history provided information for mapping the hydrogeologic units.

The study area lies within the Tacoma Basin just south of an east-west trending gravity and magnetic high. This structure is inferred as a fault or a steep monoclinal fold (Gower and others, 1985), referred to as the Narrows Structure (fig. 5) (Jones, 1996). Recent marine-seismic work near the Seattle fault zone (Gower and others, 1985) in the Puget Sound has identified two north-south trending faults within the Puget Sound. The inferred projection of these faults southward could extend south to Tacoma or beyond. Thus, the exposures of older geologic units along the Puyallup River Valley on the east side of the study area and much younger exposures along the west side may be in part due to the inferred north-south trending faults. At present the quality of the exposures along the coastline are insufficient to test for the continuation of the faults (Samuel Y. Johnson, U.S. Geological Survey, written commun., March, 1998).

The hydrogeologic units identified in this report do not necessarily correspond to geologic time-stratigraphic deposits identified in previous reports (Crandell and others, 1958; Walters and Kimmel, 1968; and Brown and Caldwell, 1985). In general, units in this report were grouped based on their continuity and lithologic type. In some parts of the study area, fine-grained glacial deposits directly overlie fine-grained interglacial deposits, and differentiating between them is difficult. Thus, these fine-grained deposits are grouped into a single semiconfining unit. Similarly, where coarse-grained glacial and interglacial deposits are vertically adjacent, they also are grouped into a single aquifer.

The surficial geologic units and lithologic units in drillers' logs from 255 inventoried wells were differentiated into hydrogeologic units (fig 6). The altitudes of the top and extent of the five uppermost hydrogeologic units were mapped. They consist of three aquifers and two semiconfining units. The aquifers consist mostly of coarse-grained sand and gravel deposits of both glacial (advance and recessional outwash) and interglacial (proglacial and coarse-grained fluvial) deposits. The semiconfining units consist mostly of fine-grained silt and clay of both glacial (till) and interglacial (lacustrine and finegrained fluvial) deposits. Due to the heterogeneity of 

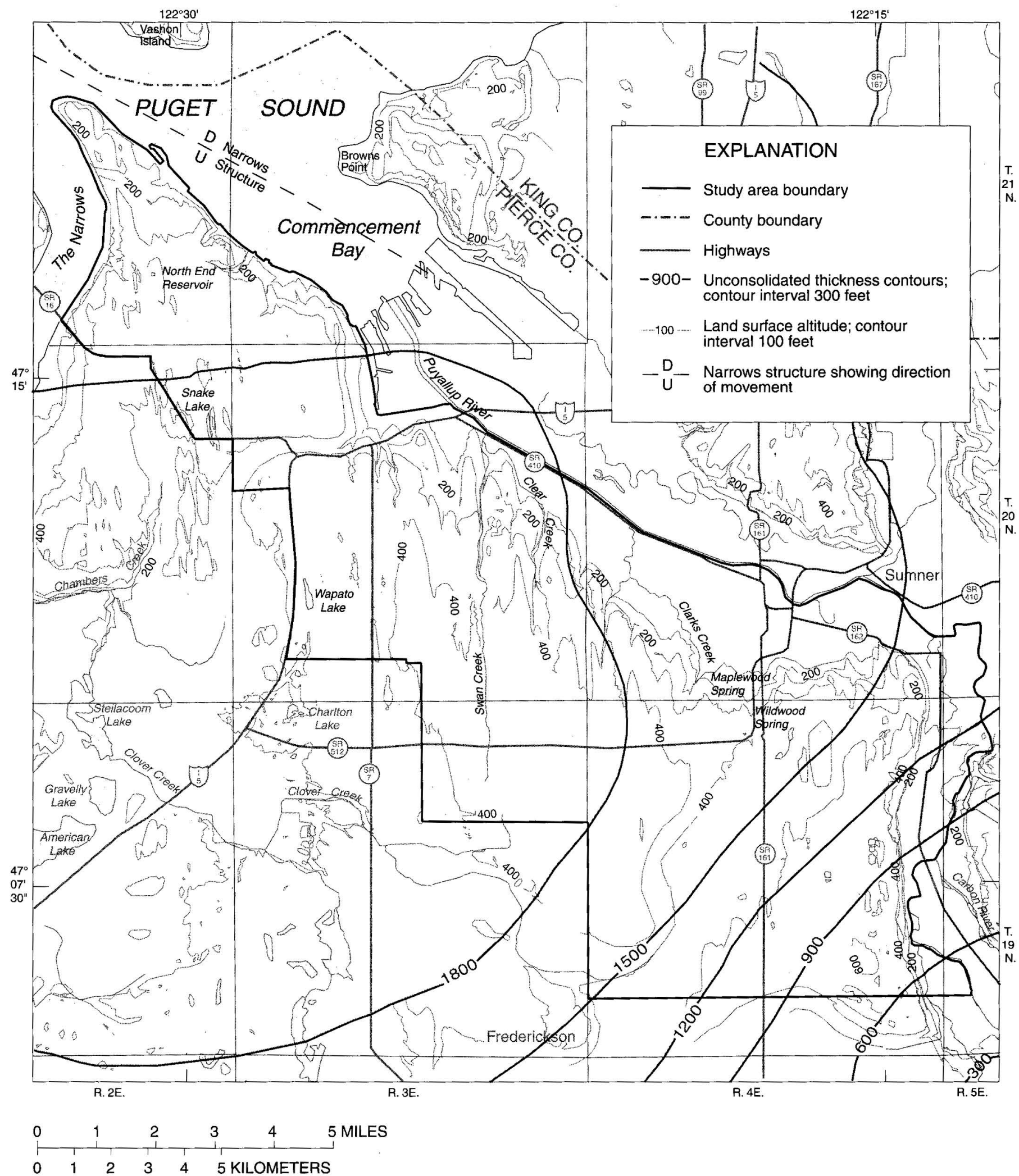

Figure 5. Thickness of unconsolidated deposits in the Tacoma-Puyallup area, Washington. (from Jones, 1996) 


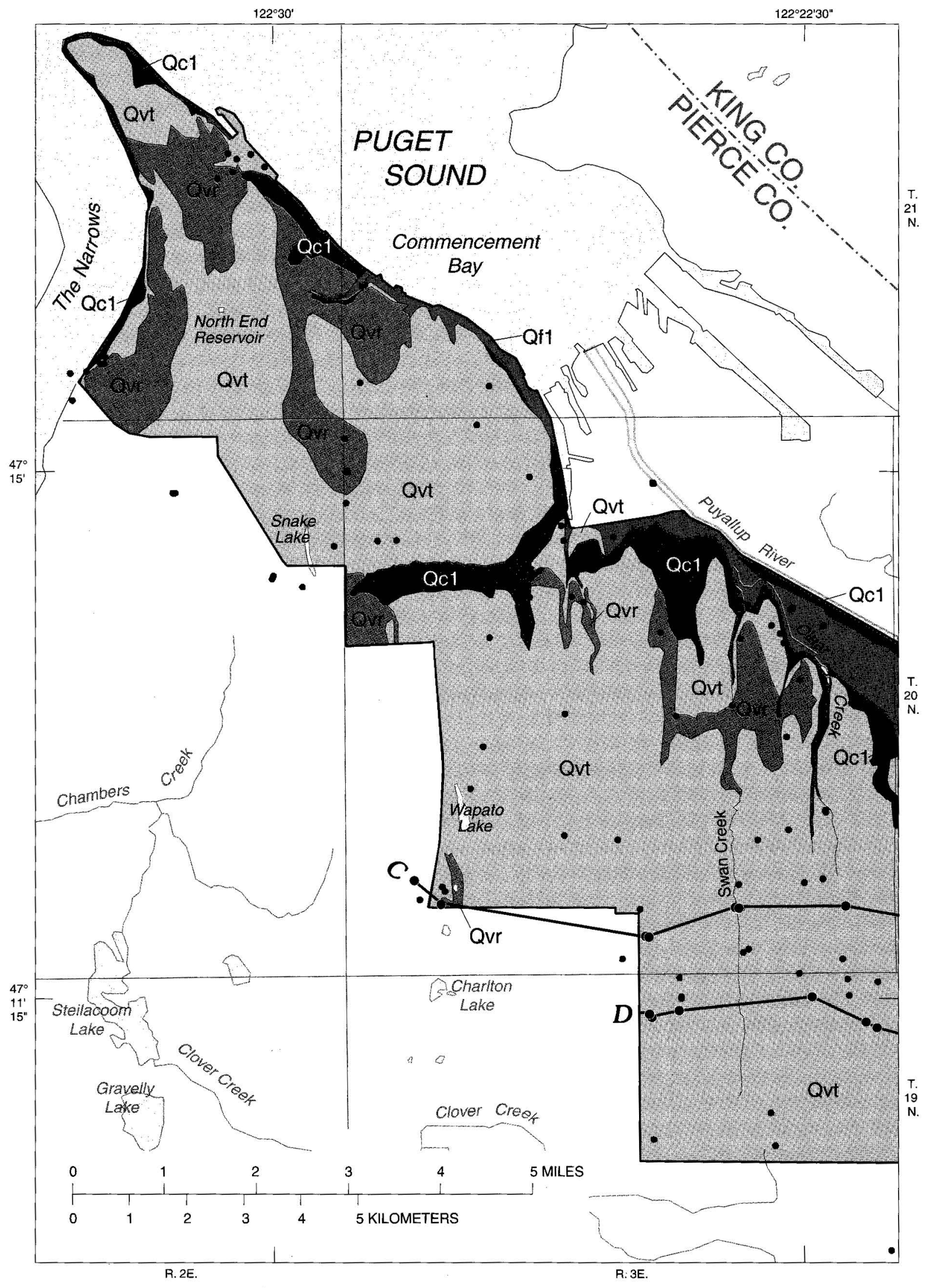




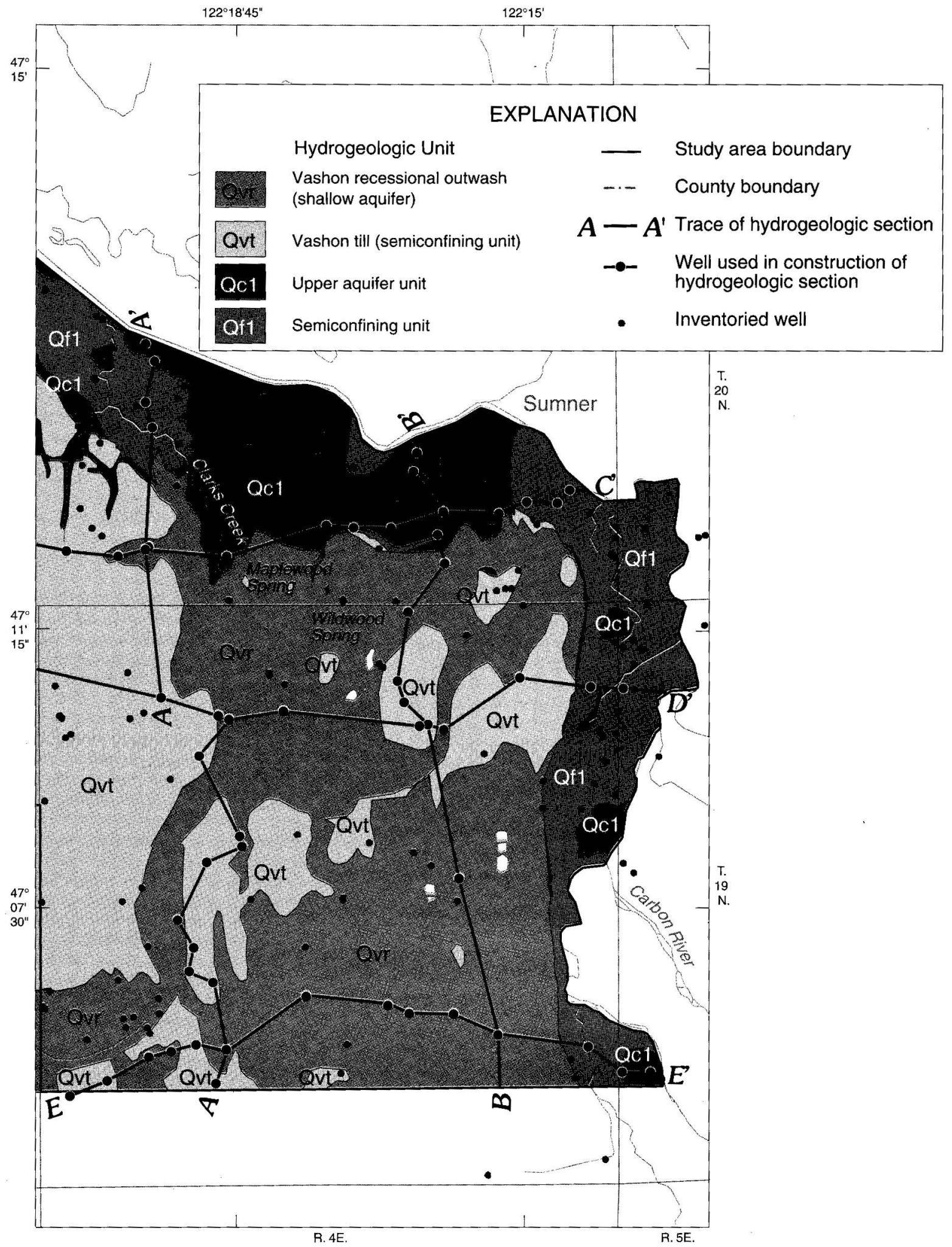

Figure 6. Distribution of hydrogeologic units at land surface, inventoried wells, and traces of the hydrogeologic sections $A-A^{\prime}$ to $E-E^{\prime}$ in the Tacoma-Puyallup area, Washington. 
these deposits, the hydrogeologic units as differentiated are not uniformly coarse-grained or fine-grained. For example, an aquifer may be composed predominantly of sand or gravel, but it may also contain relatively thin and discontinuous lenses of clay or silt. Conversely, a semiconfining unit composed predominantly of silt or clay may also contain local lenses of sand or gravel (fig. 7). These variations may also locally influence the occurrence and movement of ground water.

The 10 hydrogeologic units identified include aquifers Qvr and Qc1 through Qc4 and semiconfining units Qvt and Qf1 through Qf4. The undifferentiated unit Qdu identifies areas where there was not sufficient information to designate a hydrogeologic unit. Units Qvr, Qvt, Qc1, and Qf1 are exposed at the surface within the study area (fig. 6). The other hydrogeologic units present at depth are shown in the hydrogeologic sections (fig. 7). The hydrogeologic sections $A-A$ ' to $E-E$ ' indicate that there is considerable variation in the thickness of individual units and that all units are not necessarily continuous throughout the study area.

Unit Qvr is present at land surface (fig. 6) and generally represents the Vashon recessional outwash deposits of the Fraser Glaciation. In most places where this unit is saturated, it is a water-table aquifer. In the southeast part of the study area, Qvr generally consists of coarse deposits of gravel, cobbles, and boulders identified as the Steilacoom Gravel by Walters and Kimmel (1968). Where this unit is present in other parts of the area, it consists of sand and gravel deposits and locally may contain lenses of silt and clay. The altitude of the top and the extent of Qvr are shown in figure 8 . The altitude ranges from more than
$600 \mathrm{ft}$ to about $50 \mathrm{ft}$ (table 15, end of text), with a median of $360 \mathrm{ft}$. The thickness of this unit ranges from a thin veneer to $100 \mathrm{ft}$, with a median thickness of $22 \mathrm{ft}$, based on information from 58 inventoried wells. There were no specific-capacity data available for the wells tapping this unit; therefore, no hydraulic conductivities were calculated.

Unit Qvt occurs at land surface throughout most of the north and north-central parts of the study area and generally represents the Vashon till (fig. 6). The unit, which varies in consistency, consists primarily of unstratified clay, silt, cobbles, and boulders and can also contain lenses of sand and gravel (fig. 7). Some shallow wells completed in this unit supply water for domestic use. The altitude of the top of this unit (fig. 9) ranges from $23 \mathrm{ft}$ to $597 \mathrm{ft}$ above sea level, with a median altitude of $398 \mathrm{ft}$, based on information from 148 inventoried wells (table 15, end of text). The unit is generally present in the uplands and absent in the valleys (fig. 9). It ranges in thickness from a thin veneer to $258 \mathrm{ft}$ and has a median thickness of $71 \mathrm{ft}$. It is thickest in the uplands where it is present at the surface and generally thins in areas where it is beneath unit Qvr (fig. 7) and where it is exposed in cliff faces along the Puyallup River Valley and along the coast. From the specific-capacity data available for two wells tapping this unit, their hydraulic conductivities are calculated to be 200 and $23 \mathrm{ft} / \mathrm{d}$ (table 4). These two wells probably tap coarser lenses and are not representative of most of the unit.

Aquifer Qc1 generally lies beneath unit Qvt throughout the study area. It is exposed at the surface along the cliff faces of the coast, in incised channels, and in the

Table 4.--Summary of hydraulic conductivity values estimated from specific capacity of wells, by hydrogeologic unit in the Tacoma-Puyallup area, Washington

$[--$, not determined]

Horizontal hydraulic conductivity (feet per day)

\begin{tabular}{|c|c|c|c|c|c|c|}
\hline \multirow{2}{*}{$\begin{array}{l}\text { Hydro- } \\
\text { geologic } \\
\text { unit }\end{array}$} & \multirow[b]{2}{*}{$\begin{array}{l}\text { Number } \\
\text { of wells }\end{array}$} & \\
\hline & & Maximum & $\begin{array}{c}75 \text { th } \\
\text { Percentile }\end{array}$ & Median & $\begin{array}{c}25 \text { th } \\
\text { Percentile }\end{array}$ & Minimum \\
\hline Qvr & - & -- & -- & -- & -- & -- \\
\hline Qvt & 2 & 200 & -- & -- & -- & 23 \\
\hline Qc1 & 32 & 4,200 & 320 & 110 & 46 & 10 \\
\hline Qf1 & 1 & 10 & -- & -- & - & 10 \\
\hline Qc2 & 83 & 12,000 & 850 & 170 & 33 & 3.7 \\
\hline Qf2 & 2 & 120 & -- & -- & -- & 58 \\
\hline Qc3 & 24 & 620 & 280 & 100 & 27 & 4.1 \\
\hline Qc4 & 3 & 110 & -- & -- & -- & 9.7 \\
\hline
\end{tabular}



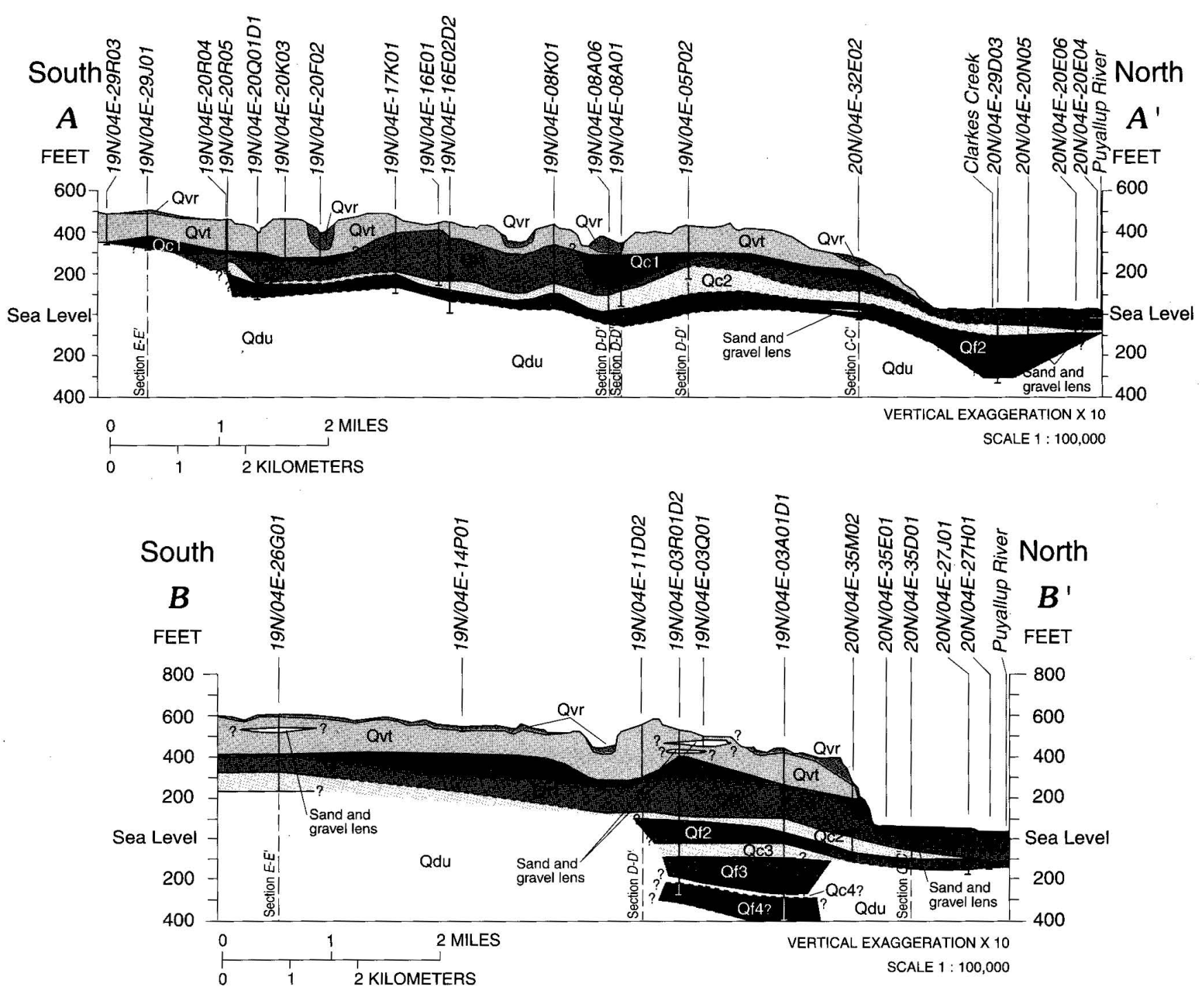

EXPLANATION

Hydrogeologic Unit

$\begin{aligned} & \text { Vashon recessional outwash } \\ & \text { (shallow aquifer) }\end{aligned}$
Ovt $\begin{aligned} & \text { Vashon Till } \\ & \text { (semiconfining unit) }\end{aligned}$
Qc1 Aquifer
Semiconfining unit
Oc2. Aquifer

Q12 Semiconfining unit
Qc3. Aquifer
Qf3 Semiconfining unit
Qc4 Aquifer
Qf4 Semiconfining unit
Qd4 Undifferentiated deposits

\begin{tabular}{ll} 
? - - Contact approximately located, dashed \\
\hline
\end{tabular}

Figure 7. Hydrogeologic sections $A-A^{\prime}$ to $E-E^{\prime}$, showing locations of hydrogeologic units in the Tacoma-Puyallup area, Washington. Traces of sections are shown on figure 6. 

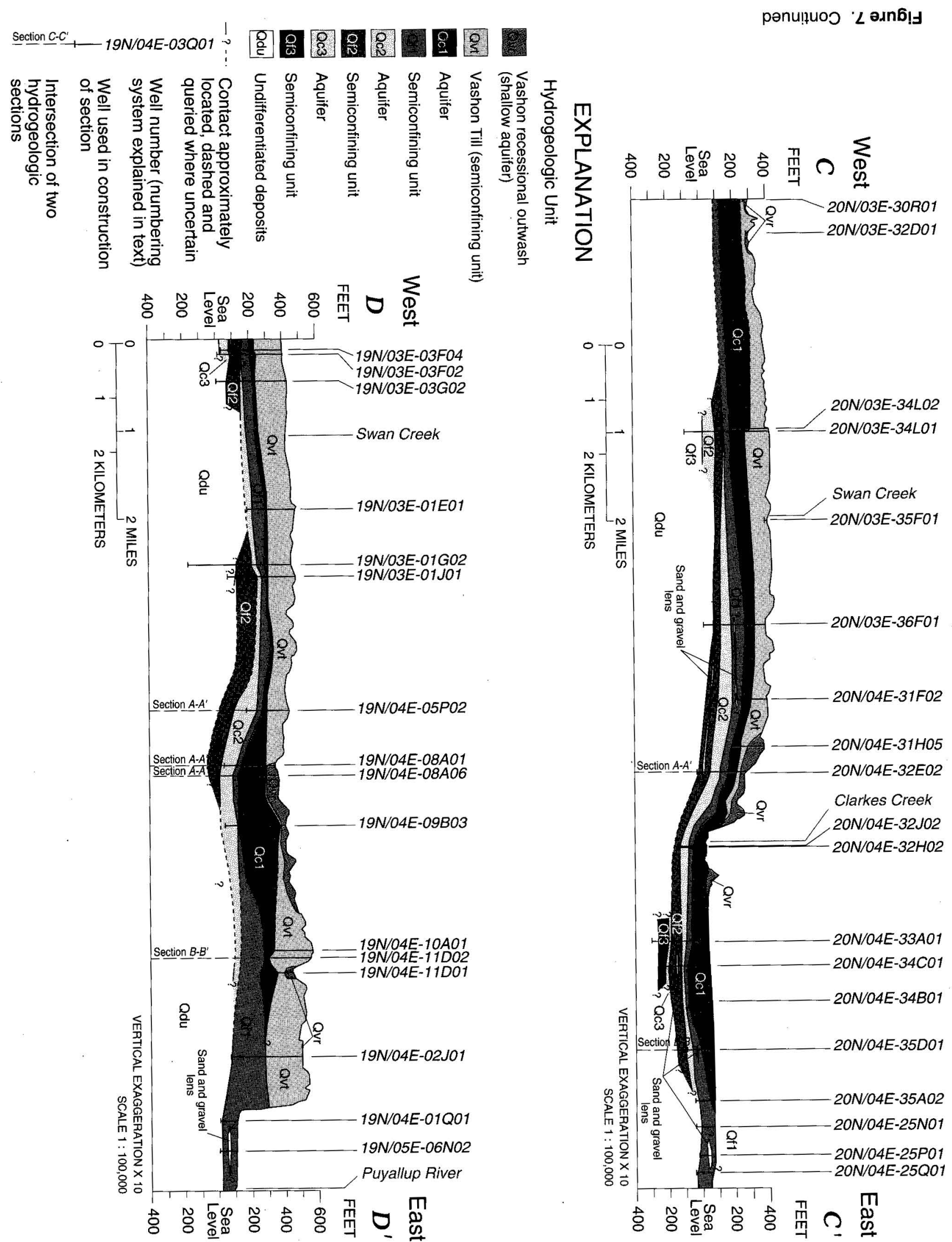


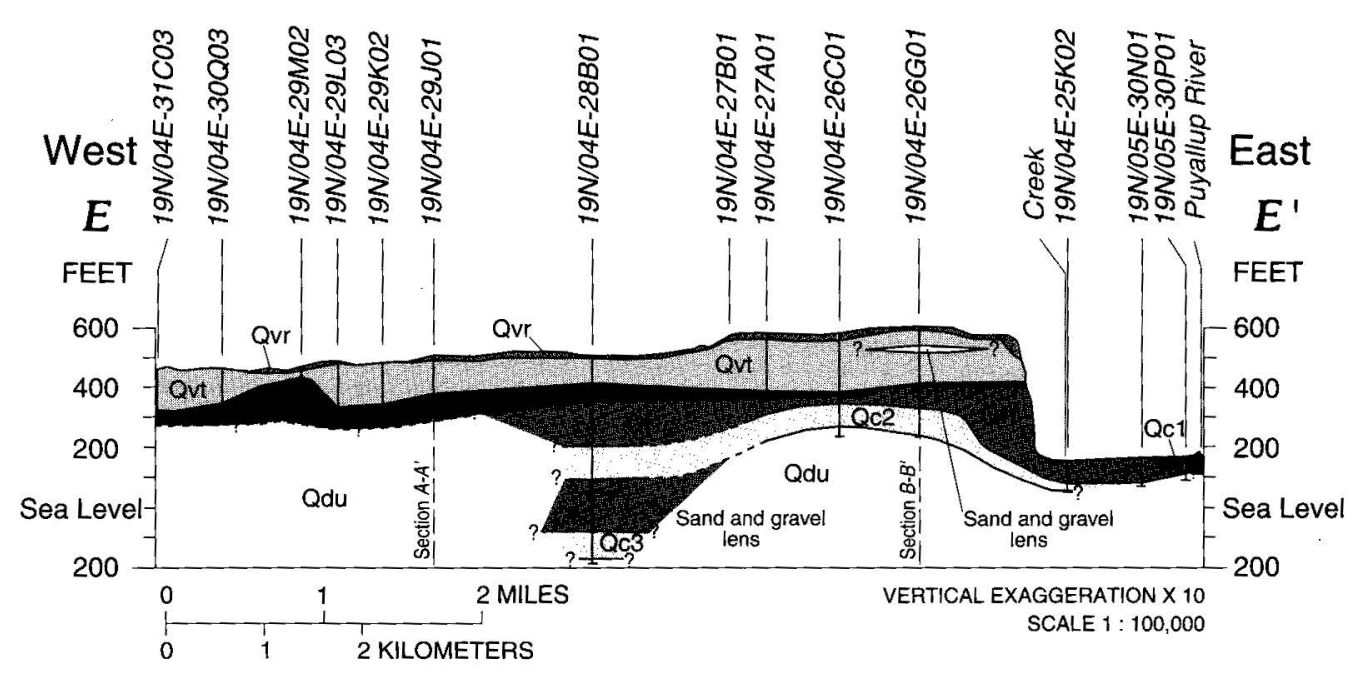

\section{EXPLANATION}

Hydrogeologic Unit

Vashon recessional outwash
(shallow aquifer)

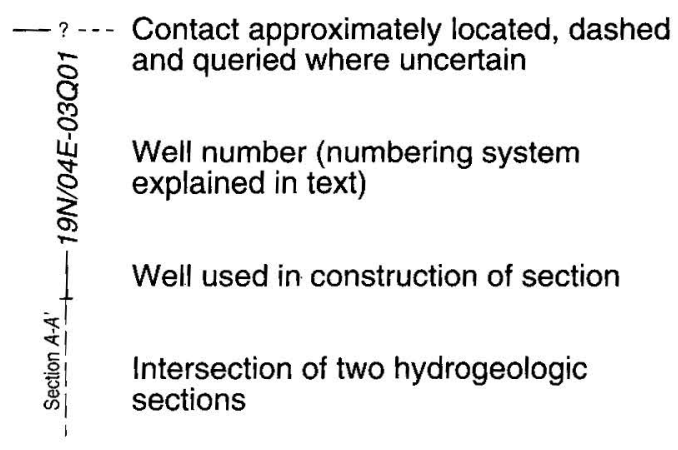

Figure 7. Continued 


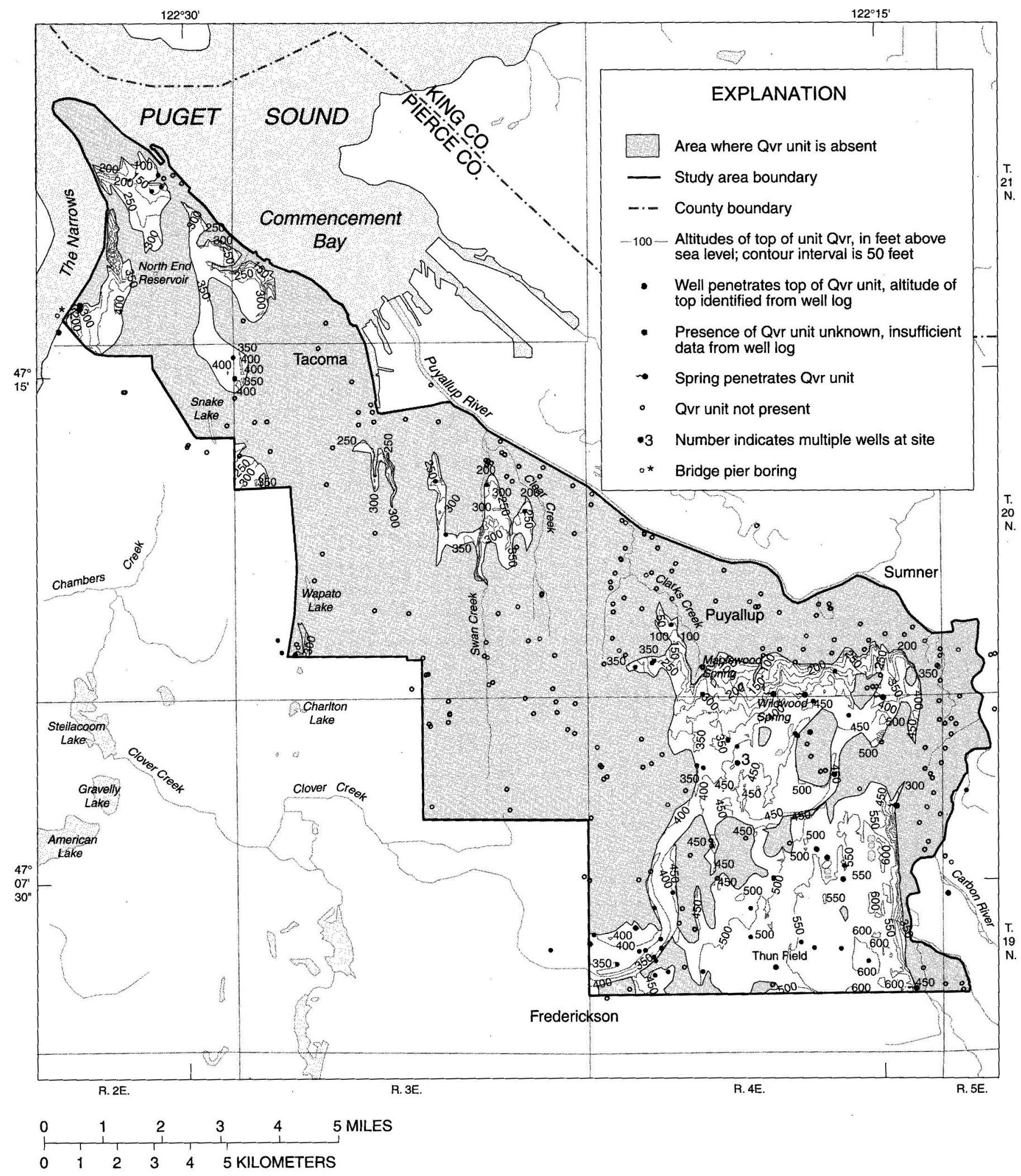

Figure 8. Altitude of the top and extent of hydrogeologic unit Qvr in the Tacoma-Puyallup area, Washington. 


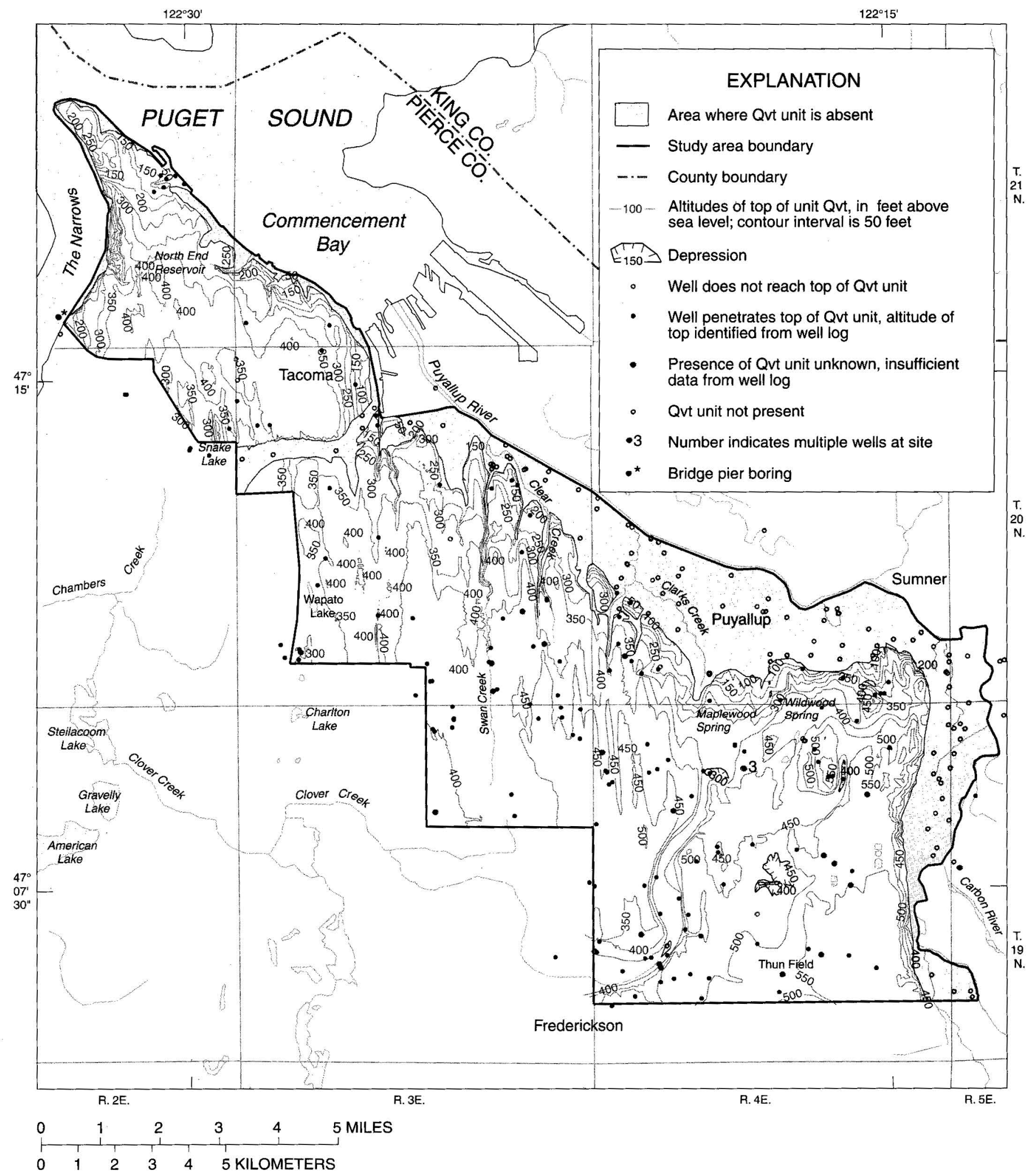

Figure 9. Altitude of the top and extent of hydrogeologic unit Qvt in the Tacoma-Puyallup area, Washington. 
Puyallup River Valley (fig. 6). Aquifer Qc1 is generally a confined aquifer except where it is exposed at the surface, where it is unconfined, or not completely saturated beneath Qvt. It consists largely of sand and gravel deposits but does contain clay and silt within the sand and gravel matrix. This aquifer is tapped as a source of water by domestic and public-supply wells within the study area, and spring water from this unit is also used as a source of domestic and public supply. The altitude of the top of this aquifer ranges from $50 \mathrm{ft}$ below sea level to $509 \mathrm{ft}$ above sea level (fig. 10). The median altitude is $238 \mathrm{ft}$, based on information from 162 inventoried wells (table 15, end of text). The thickness of Qc1 ranges from a few feet to $297 \mathrm{ft}$, with a median thickness of $41 \mathrm{ft}$. Aquifer Qc1 is generally thinnest in the uplands and thickest in valleys and topographically low areas (fig. 7). Specific-capacity data were available for 32 wells tapping this aquifer. Calculated hydraulic conductivities range from 10 to $4,200 \mathrm{ft} / \mathrm{d}$. The median is $110 \mathrm{ft} / \mathrm{d}$, and the $75 \mathrm{th}$ and $25 \mathrm{th}$ percentiles are 320 and $46 \mathrm{ft} / \mathrm{d}$, respectively (table 4). There were insufficient data to map the aerial distribution of hydraulic conductivity for this aquifer.

Unit Qf1 generally lies beneath aquifer Qc1. It is exposed at the surface near sea level along the cliff faces of the coast and in the Puyallup River Valley (fig. 6). The unit consists largely of clay but contains some volcanic, mudflow, and alluvial deposits. It also contains lenses of sand and gravel (fig. 7). Some of the small lenses of sand and gravel are tapped by wells within the study area and supply small quantities of water for domestic use. The altitude of the top of this unit (fig. 11) ranges from $150 \mathrm{ft}$ below sea level to $413 \mathrm{ft}$ above sea level (table 15 , end of text). The median altitude is $120 \mathrm{ft}$, based on data from 161 inventoried wells. This unit ranges in thickness from a thin veneer to $248 \mathrm{ft}$, with a median of $56 \mathrm{ft}$. It is generally thickest in the upland and thin in areas of topographic lows. Few water wells tap this unit. Specific-capacity data were available for only one well in this unit. The calculated hydraulic conductivity is $10 \mathrm{ft} / \mathrm{d}$ (table 4).

Aquifer Qc2 generally lies beneath unit Qf1 and is a confined aquifer. It consists largely of gravel or sand and gravel deposits, but does contain thin beds of silt and clay. This unit also contains some mudflow and volcanic deposits. Most of the wells inventoried in the study area are completed in this aquifer (table 15, end of text). The altitude of the top of this aquifer (fig. 12) ranges from $226 \mathrm{ft}$ below sea level to $345 \mathrm{ft}$ above sea level. The median altitude of this aquifer is $55 \mathrm{ft}$, based on information from 145 inventoried wells. Although most wells completed in this aquifer do not fully penetrate it, its median thickness, based on the depth of the wells that penetrate it, is $27 \mathrm{ft}$.
Specific-capacity data were available for 83 wells tapping this aquifer and calculated hydraulic conductivities range from 3.7 to $12,000 \mathrm{ft} / \mathrm{d}$. The median is $170 \mathrm{ft} / \mathrm{d}$, and the 75 th and 25 th percentiles are 850 and $33 \mathrm{ft} / \mathrm{d}$, respectively (table 4). There were insufficient data to map the aerial distribution of hydraulic conductivity in this aquifer.

Unit Qf2 generally lies beneath aquifer Qc2. It consists largely of compact clay and silt, but also contains lenses of sand and gravel and mudflow deposits. It may also contain minor amounts of peat and volcanic deposits (Walters and Kimmel, 1968; and Dragovich and others, 1994). Wells tapping sand and gravel units within this unit generally yield small quantities of water to wells. The altitude of this unit ranges from $395 \mathrm{ft}$ below sea level to $269 \mathrm{ft}$ above sea level. Its median altitude is $15 \mathrm{ft}$ above sea level, based on information from 69 inventoried wells (table 15, end of text). Its extent and top are not mapped because few wells penetrate to this depth, but it is shown where it is known to be present in figure 7 . This unit ranges in thickness from a thin veneer to $177 \mathrm{ft}$, with a median of $55 \mathrm{ft}$. Only two water wells are known to tap this unit. Specific-capacity data were available for these two wells which tap sand and gravel deposits within this unit; their calculated hydraulic conductivities are 120 and $58 \mathrm{ft} / \mathrm{d}$ (table 4).

Aquifer Qc3 generally lies beneath unit Qf2. It is largely sand and gravel, but there is clay and silt within the sand and gravel matrix. It is tapped by public-supply and domestic wells within the study area. The altitude of this aquifer ranges from $432 \mathrm{ft}$ below sea level to $135 \mathrm{ft}$ above sea level, with a median altitude of $128 \mathrm{ft}$ below sea level, based on information from 44 inventoried wells (table 15). The extent and top of this aquifer are not mapped because few wells penetrate to this depth, but they are shown where present in figure 7. In thickness, this aquifer ranges from $5 \mathrm{ft}$ to $276 \mathrm{ft}$, with a median of $59 \mathrm{ft}$. Specificcapacity data were available for 24 wells tapping this aquifer, and calculated hydraulic conductivities range from 4.1 to $620 \mathrm{ft} / \mathrm{d}$. The median value is $100 \mathrm{ft} / \mathrm{d}$, and the 75 th and 25 th percentiles are 280 and $27 \mathrm{ft} / \mathrm{d}$, respectively (table 4).

The alternating sequence of fine-grained and coarse-grained deposits appears to continue at depth below Qc3, but the information is sparse. Based on available information, these deep deposits were delineated into units Qf3, Qc4, and Qf4, which are shown on figure 7 and included in table 15 (end of text) and appendix 1. The data are based on 21 wells for Qf3, 11 wells for Qc4, and 5 wells for Qf4. Specific-capacity data were available for three wells for aquifer Qc4. The calculated hydraulic 


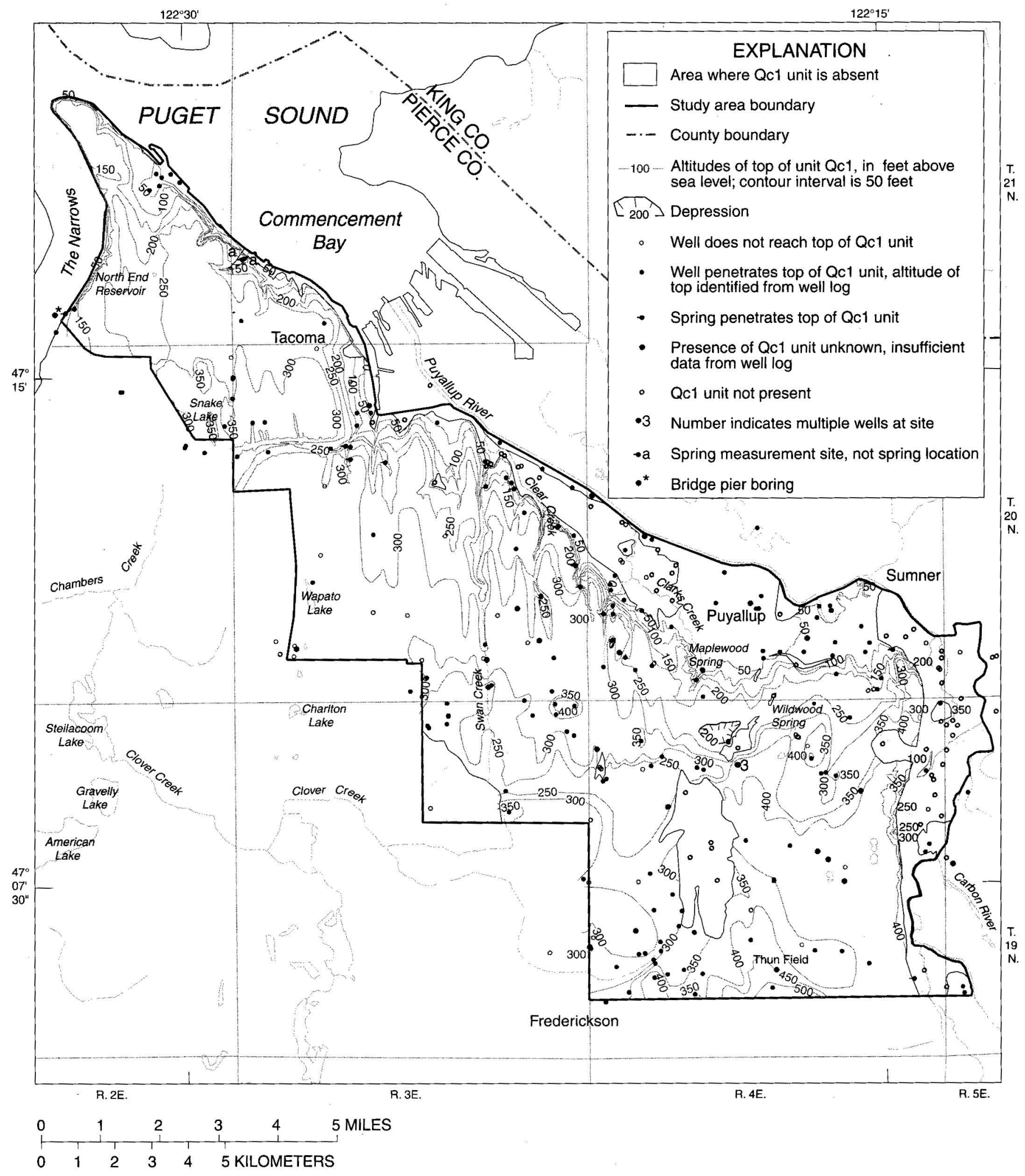

Figure 10. Altitude of the top and extent of hydrogeologic unit Qc1 in the Tacoma-Puyallup area, Washington. 


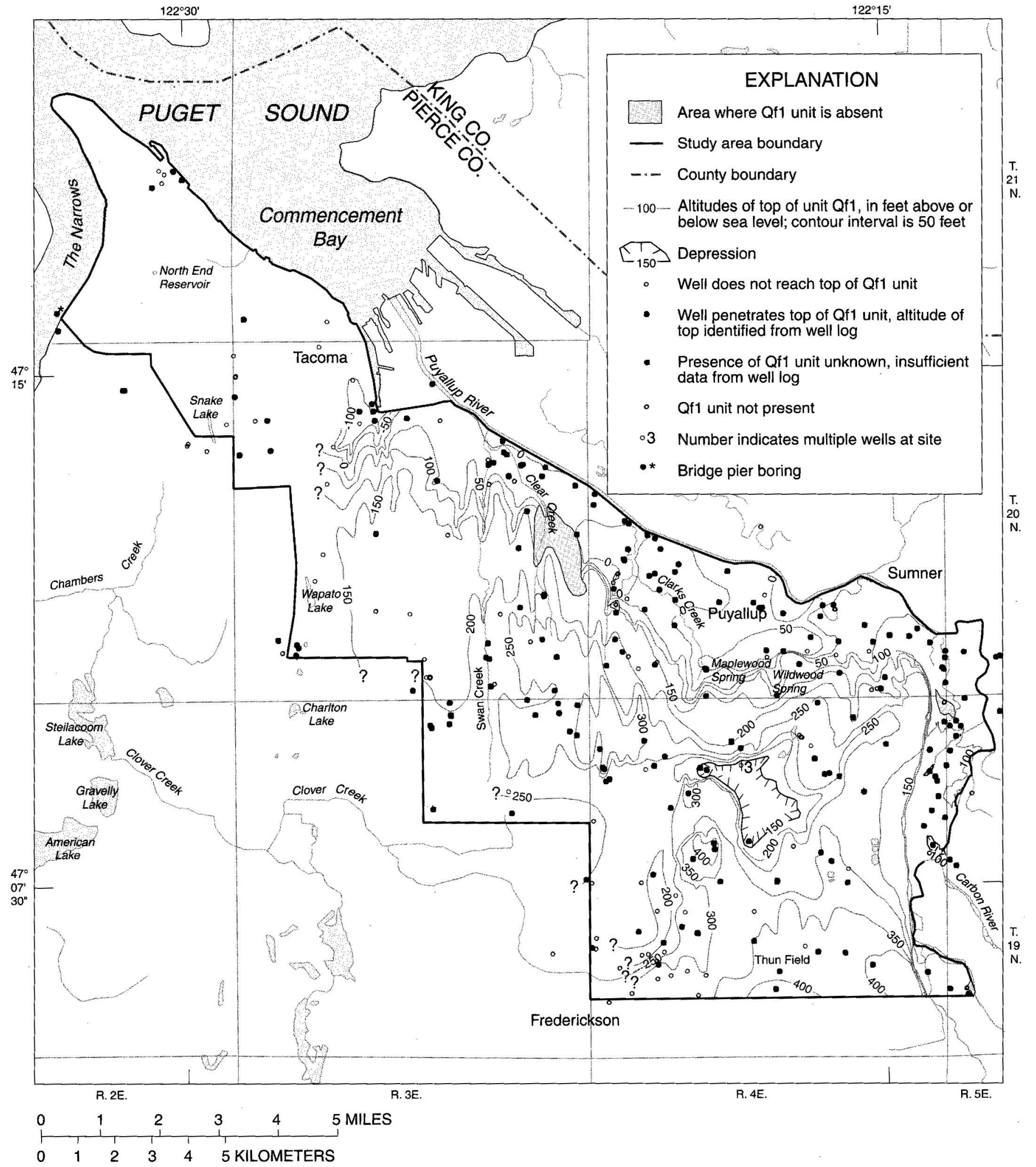

Figure 11. Altitude of the top and extent of hydrogeologic unit Qf1 in the Tacoma-Puyallup area, Washington. 


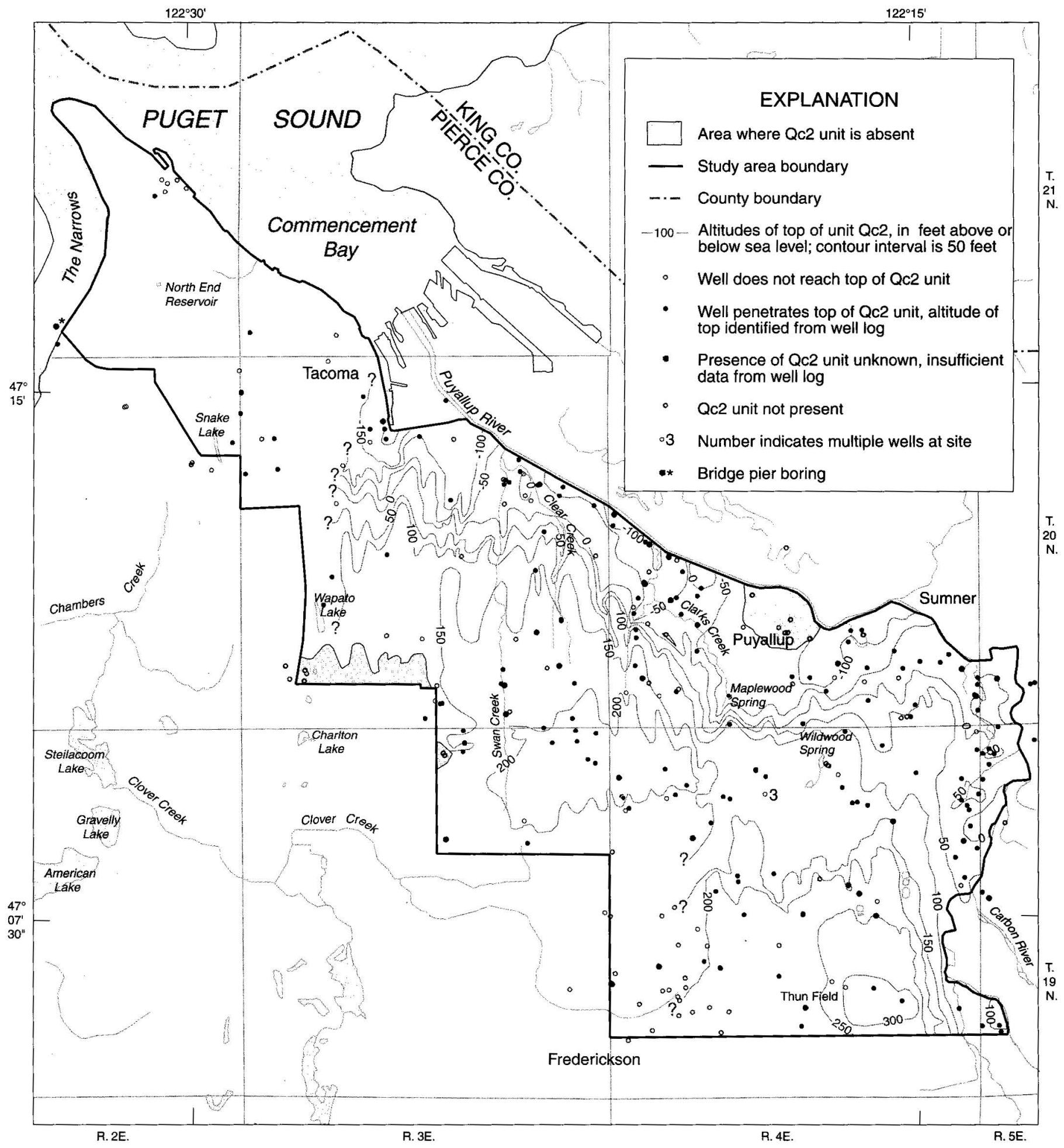

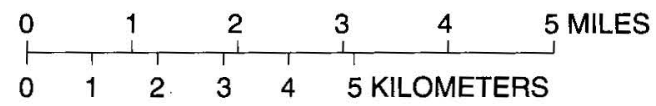

Figure 12. Altitude of the top and extent of hydrogeologic unit Qc2 in the Tacoma-Puyallup area, Washington. 
conductivities are 110 and $9.7 \mathrm{ft} / \mathrm{d}$ (table 4 ). All remaining undifferentiated deposits are grouped into a hydrogeologic unit designated Qdu (fig 7). This unit also includes all deposits at depth where there is no information available to delineate the shallower hydrogeologic units, for example, Qf2 and Qc3. Because of the lack of data, no geologic or hydrogeologic properties were assigned to this unit. In the future, aquifers within this unit may be utilized as a source of water, but cost, lack of information, and water availability at shallower depths preclude it from being considered at present.

\section{GROUND-WATER SYSTEM}

The basic elements of ground-water systems are described in this section. This is followed by a description of the ground-water movement system of the study area, which includes recharge, ground-water movement, discharge, water-budget calculations, and water-level fluctuations.

The hydrologic cycle describes the ways in which water moves through the earth. During its continual circulation from ocean to atmosphere, to land, and then back to the ocean, water becomes temporarily stored in streams, lakes, wetlands, soils, and the ground.

Water in the atmosphere condenses to form clouds and eventually falls to the earth's surface as precipitation in the form of rain or snow, which is the source of all fresh water. Part of this precipitation runs off to roadside drainage ditches, storm drains, streams, lakes, wetlands, or directly back to the ocean. A portion of the precipitation is evaporated directly back to the atmosphere from the ocean, lakes, streams, bare soil, and plant surfaces, and part infiltrates into the ground. Of the precipitation that enters the ground, some is drawn up by plant-roots and returned to the atmosphere by transpiration from the leaves, and some continues to percolate downward, recharging the ground-water system. Some of the ground water may discharge to the land surface by seepage to lakes, wetlands, streams, and springs, which then makes its way back to the ocean. A small quantity of the ground water is also withdrawn by wells. The rest of the ground water discharges back to the ocean in the form of springs and seeps along the ocean floor.

On a long-term basis, many ground-water systems are usually in a state of dynamic equilibrium; that is, inflow to the system is equal to the outflow from the system, and there is little or no change in the quantity of water stored in the system. Precipitation falling to the earth can be intercepted by vegetation, run off the surface, or infiltrate into the ground. The water that infiltrates into the ground can be transpired by plants, evaporate from bare soil, become part of the shallow subsurface flow, or percolate downward to the water table and recharge the ground water.

Ground water is found throughout the study area under confined and unconfined conditions. Parts of some of the hydrogeologic units may be unsaturated where they are truncated along the coastal bluffs, but most of the units contain at least some ground water.

The ground-water system in northwestern Pierce County consists of multiple aquifer and semiconfining units contained in the thick sequence of unconsolidated Quaternary deposits within the study area (fig. 5). The aquifers and semiconfining units have variable boundaries and hydraulic properties. The defined aquifers are generally composed of coarse-grained deposits, but local lenses of fine-grained silt and clay may affect their permeability and flow characteristics. Conversely, the semiconfining units are generally composed of fine-grained silt and clay deposits, but local lenses of coarse-grained sand and gravel deposits may also affect their permeability and flow characteristics.

The boundaries of the ground-water system within the study area are the water table at the top, the bedrock at the bottom, the Puyallup River and Commencement Bay on the east, Puget Sound on the north, and The Narrows on the northwest. The south and southwest boundary is approximately the northeast divide of the CloverChambers Creek Basin.

The upper boundary is the water table, which can be an inflow, outflow, or no-flow boundary, based on its proximity to land surface, the season of the year, and the local directions of ground-water movement. The water table is not a static boundary, but rises and falls with the seasons throughout the year. During the winter months, when precipitation is at its highest, water recharges the groundwater system and the water table rises. During the summer months, with less precipitation, the water table declines. In areas where the water table is close to the land surface, the water can move upward by capillary action and evaporate back to the atmosphere at land surface, or if within the root zone, it may be transpired back to the atmosphere by plants. The bedrock is assumed to be relatively impermeable in comparison to the thick sequence of unconsolidated Quaternary deposits and is considered the lower flow boundary in the study area. 
There is no geographic or physiographic feature to delineate the regional southwest boundary of the study area. On a local scale, the northeast divide of the Clover-Chambers Creek Basin (fig. 1) does act as a boundary for the shallow ground-water system. On the northeast side of the divide, shallow ground water generally flows north and northeast to the Puget Sound, Commencement Bay, and the Puyallup River. On the southwest side of the divide, the water flows southwest to Clover and Chambers Creeks (fig. 1). The source of ground water flowing north into the study area at depths below unit Qc1 extends south below the study-area boundary.

\section{Ground-Water Recharge}

Recharge to the ground-water system is primarily by percolation of precipitation. Other minor sources of recharge are seepage from streams, lakes, and wetlands, septic field leachate, irrigation, and leakage from water lines. Recharge from precipitation occurs everywhere, except in areas where ground water is discharging at land surface, for example at seeps and springs and in areas covered by impervious materials such as asphalt and concrete. But these impervious materials may only delay and redistribute the precipitation that runs off into storm drains or dry-hole catchment or encounters permeable deposits.

The area-weighted estimated long-term average ground-water recharge calculated for the TacomaPuyallup study area is $\mathbf{1 4 . 1}$ inches per year. The estimates were obtained from computations based on precipitation and area types that included surficial geology, land use, and information about whether the area was sewered or on a septic system. Geographic information system (GIS) techniques were employed to combine a precipitationdistribution map; a simplified surficial geology map that identifies areas of coarse- and fine-grained deposits; a simplified land-use map divided into grass, which includes all agricultural land and low-density urban areas, forest, saturated land, and high-density urban areas; and a map separating sewered areas from nonsewered areas. In addition the GIS techniques were used to generate a map of the distribution and quantity of recharge for the study area (fig. 13).

Recharge estimates were based on the relation between mean annual precipitation and surficial geology developed for east King County (Turney and others, 1995). In that study, regression equations were developed and used to estimate recharge in areas of fine-grained (till) and coarse-grained (outwash) deposits, and, based on the amount of annual precipitation, ground-water recharge through the till ranged from 10 to 25 inches per year and through the outwash from 15 to 42 inches per year (Turney and others, 1995). More recent studies in areas mantled by till (Bauer and Mastin, 1997; Mastin, 1996) reported annual area-weighted average recharge values for a 2- to 3-year period in three nearby basins--Clover, Beaver, and Vaughn Basins, located in central and northwestern Pierce County. It was assumed that the average of the average recharge from the three basins is representative of the variability of the till within the study area. The ratio of the average recharge to precipitation derived from these three basins (Bauer and Mastin, 1997) was applied directly to the mean annual precipitation value (National Oceanic and Atmospheric Administration, 1995 and 1996). Thus, for fine-grained grass covered areas, the ratio 0.178 was used, and for fine-grained forested areas, the ratio 0.115 was used. For areas underlain by coarse-grained deposits, the regression equation, shown below, developed for east King County (Turney and others, 1995) was used to compute recharge.

$$
R C H G=-38.23+26.3[\ln (P R E C I P)],
$$

where

$$
\begin{gathered}
R C H G=\text { recharge, as a percent of precipitation, } \\
\text { and } \\
\ln (P R E C I P)=\begin{array}{l}
\text { the natural logarithm of precipitation, } \\
\text { in inches per year. }
\end{array}
\end{gathered}
$$

To convert $R C H G$ to recharge, in inches per year, multiply $R C H G$ by $0.01(P R E C I P)$.

Recharge in areas defined as saturated land was assumed equal to zero. These areas included lakes, ponds, and wetlands.

Recharge estimates were adjusted for those areas where waste water was disposed of on site (septic systems). Sapik and others (1988) estimated that about 71 percent of the waste water discharged by a septic system is available for recharge through the drain field. No adjustment was made to recharge values for areas where waste water is carried by sewers to a centrally located treatment plant. Sapik and others (1988) assumed that the amount of ground water that sewers intercept and carry away is about the same amount as they leak to the ground-water system.

Lastly, the recharge estimates were adjusted to account for leakage from water-supply distribution systems in areas where the water is imported from outside 


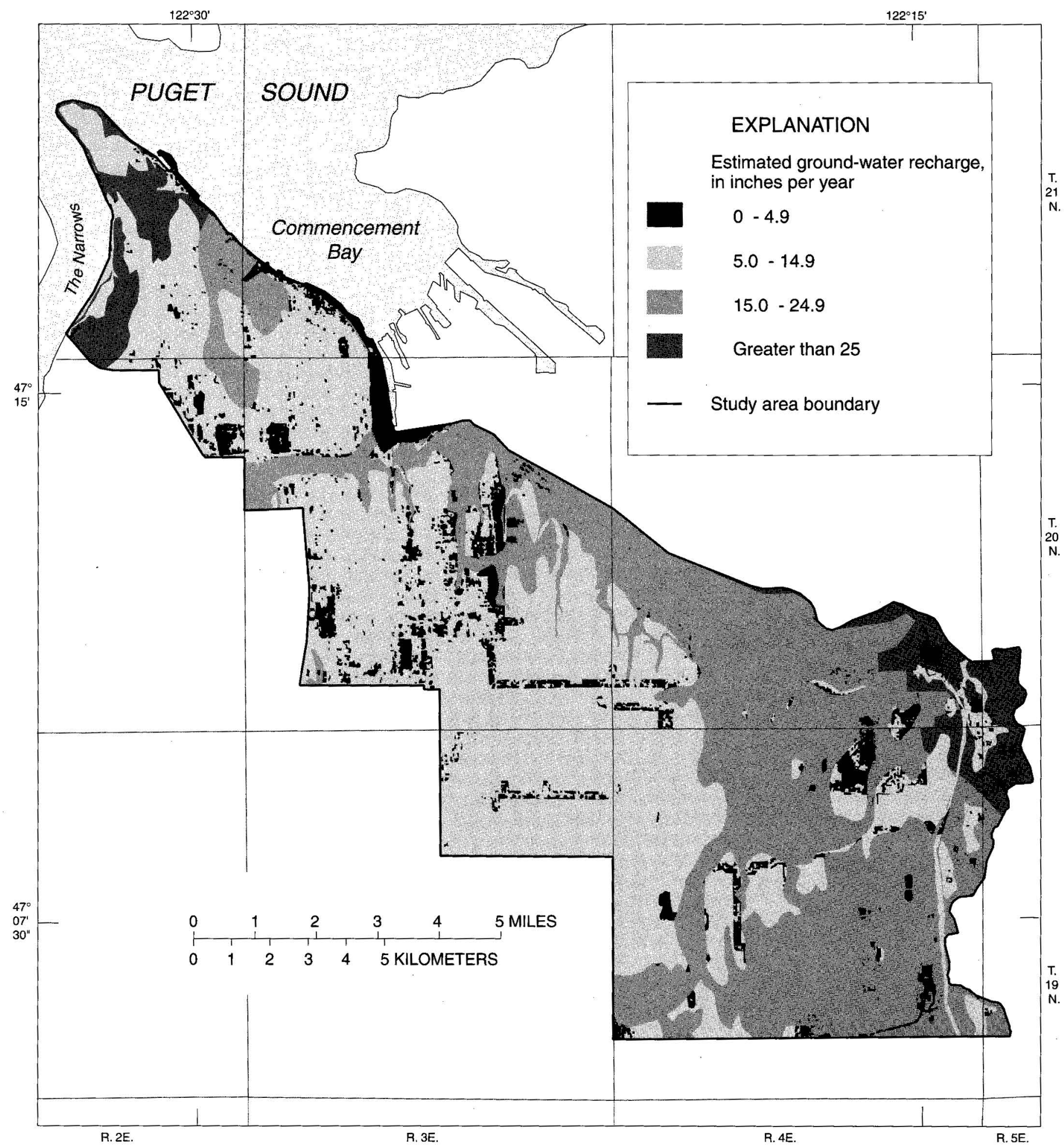

Figure 13. Distribution of estimated ground-water recharge in the study area, in inches per year in the Tacoma-Puyallup area, Washington. 
the study area. This adjustment, which was applied only in high-density urban areas, was a value of 7 percent. This value is based on estimates of water losses reported from water systems inventoried in the study area.

The distribution of the long-term average annual recharge based on the previously described equations within the study area (fig. 13) reflects the combined effects of precipitation, surficial geology, land use, and type of sewage disposal. The resulting map shows recharge highest in the northwest and southeast parts of the study area. In general, the areas of lowest recharge are in areas where till is present at the surface and where precipitation is low. But the recharge through the till may be greater if the degree of compaction is less and composition is coarser than in the average for the three basins studied by Bauer and Mastin (1997). The estimated recharge is also within the possible range given by chloride mass balance calculations. This recharge map represents the distribution of the estimated amount of water that reaches the water table for recharge to the ground-water system. The unusual patterns of low recharge ( 0 to 4.9 inches) are largely due to the distribution of land use and sewered areas. No attempt was made to determine the fate of this recharge in quantitative terms once it becomes a part of the ground-water system. In areas with steep hillsides, some of the recently recharged ground water may move only short distances and quickly discharge into nearby streams, seeps, or springs. It may also only travel short distances in discharge areas such as the Puyallup River Valley. However, in other areas, the ground water may move vertically downward and enter the regional flow system, where it may not discharge for many years.

\section{Ground-Water Movement}

The direction of ground-water movement can be inferred from maps of water-level altitude contours. Ground-water movement generally is from areas of recharge to areas of discharge in the direction of decreasing water-level altitudes and perpendicular to the water-level altitude contours. Normally the predominant direction of ground-water movement in aquifers is lateral; however, there can be a vertical component to the direction of motion that is downward in recharge areas and upward in areas of discharge. In discharge areas, water levels in aquifers may be at or above land surface, and water levels in the deeper aquifers may be higher than those in the aquifer at or near land surface.
After the hydrogeologic units were delineated and wells were assigned to one or more of the aquifers, waterlevel altitude maps were constructed, based on available data, for aquifers Qc1 and Qc2 (figs. 14 and 15). These two maps were used to assist in describing and interpreting the general direction of ground-water movement in the study area. Where water levels were unavailable from inventoried wells, some historical water levels were used (appendix 1).

Ground water within the study area generally moves from the areas with high land surface altitudes in the south and southwest, to Puget Sound, The Narrows, and Commencement Bay to the north and to the Puyallup River on the east and northeast. Locally the ground water discharges toward the streams and creeks and some of the glacial outwash channels in the study area (fig. 1).

Ground-water movement in the unconfined Qvr aquifer generally follows the land surface gradient, with water moving from high-altitude areas in the southeast to the north toward Swan, Clear, and Clarks Creeks, to the northeast and east to the Puyallup River, and to the southwest to Clover and Chambers Creeks. Qvr is often truncated along the steep bluffs of the study area, and water within this unit is discharged at the surface in the form of seeps and springs, which then discharge into one of the creeks, the Puyallup River, Commencement Bay, The Narrows, or Puget Sound. Due to the discontinuous nature of this aquifer and the lack of data, no water-level altitude map was constructed.

Ground-water movement in aquifer Qc1 is shown in figure 14. Water-level altitude contours were drawn where data were available. However, the distribution of inventoried wells in this unit made contouring the water-level altitudes difficult. In general, ground water in this unit moves north, east, and northeast to the Puyallup River, Commencement Bay, The Narrows, and Puget Sound. It also appears to move southwest to the Clover Creek Channel, and some ground water probably discharges to the South Tacoma Channel. But less data are available for the Tacoma Channel area, and direction of movement may be dependent on the amount of nearby ground-water pumpage. Based on the water-level altitude contours in the southeast portion of the study area, the lateral groundwater gradient is about $100 \mathrm{ft} / \mathrm{mi}$ (feet per mile). Unit Qc1 is also truncated in areas along the steep bluffs within the study area, and the ground water within this unit is also discharged as seeps or springs. Ground water that is not captured for domestic and public-supply use generally discharges into one of the creeks, the Puyallup River, Commencement Bay, The Narrows, and Puget Sound. 


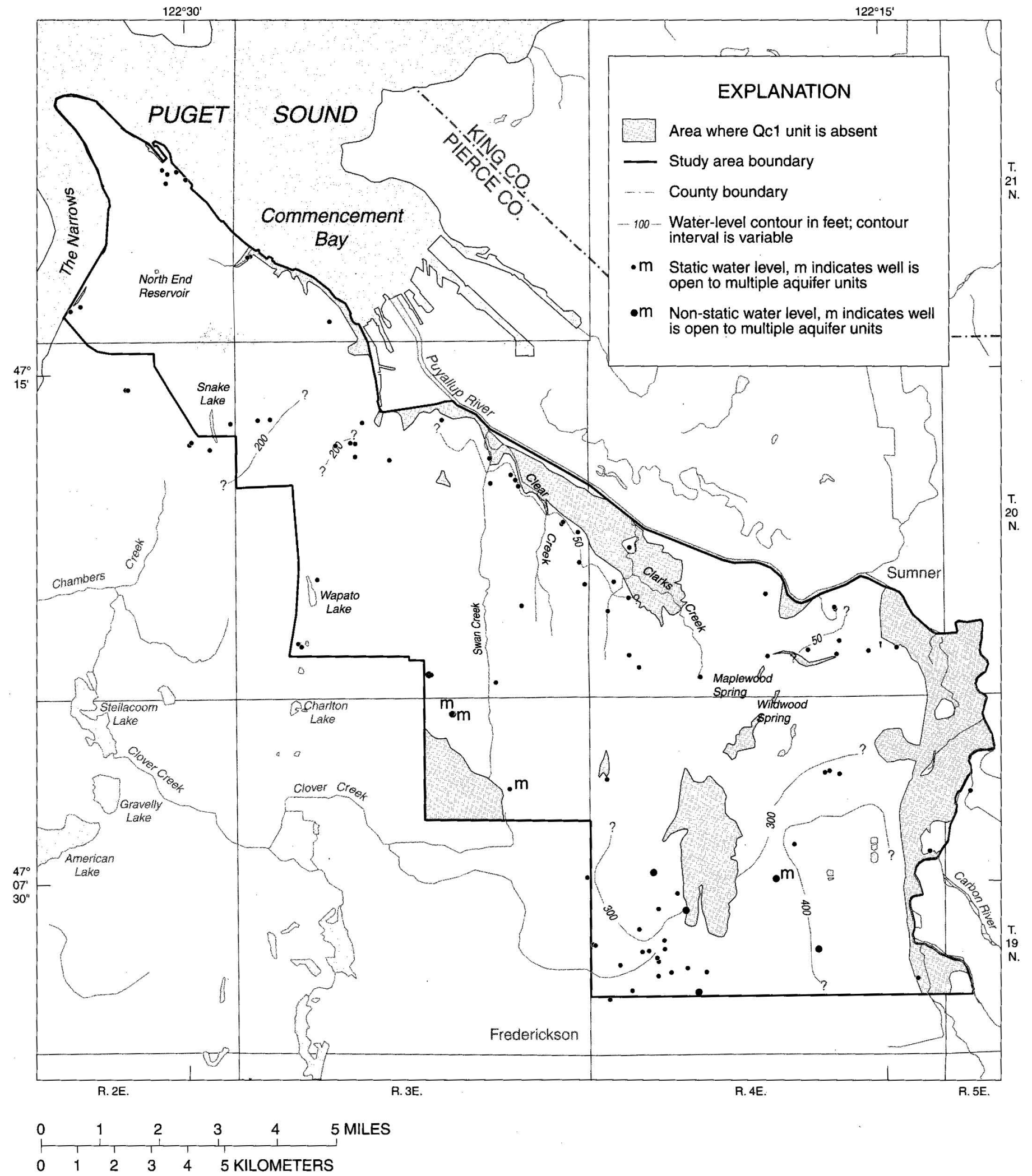

Figure 14. Water-level altitude in aquifer Qc1. Water levels were compiled from current and historical data in the TacomaPuyallup area, Washington. 


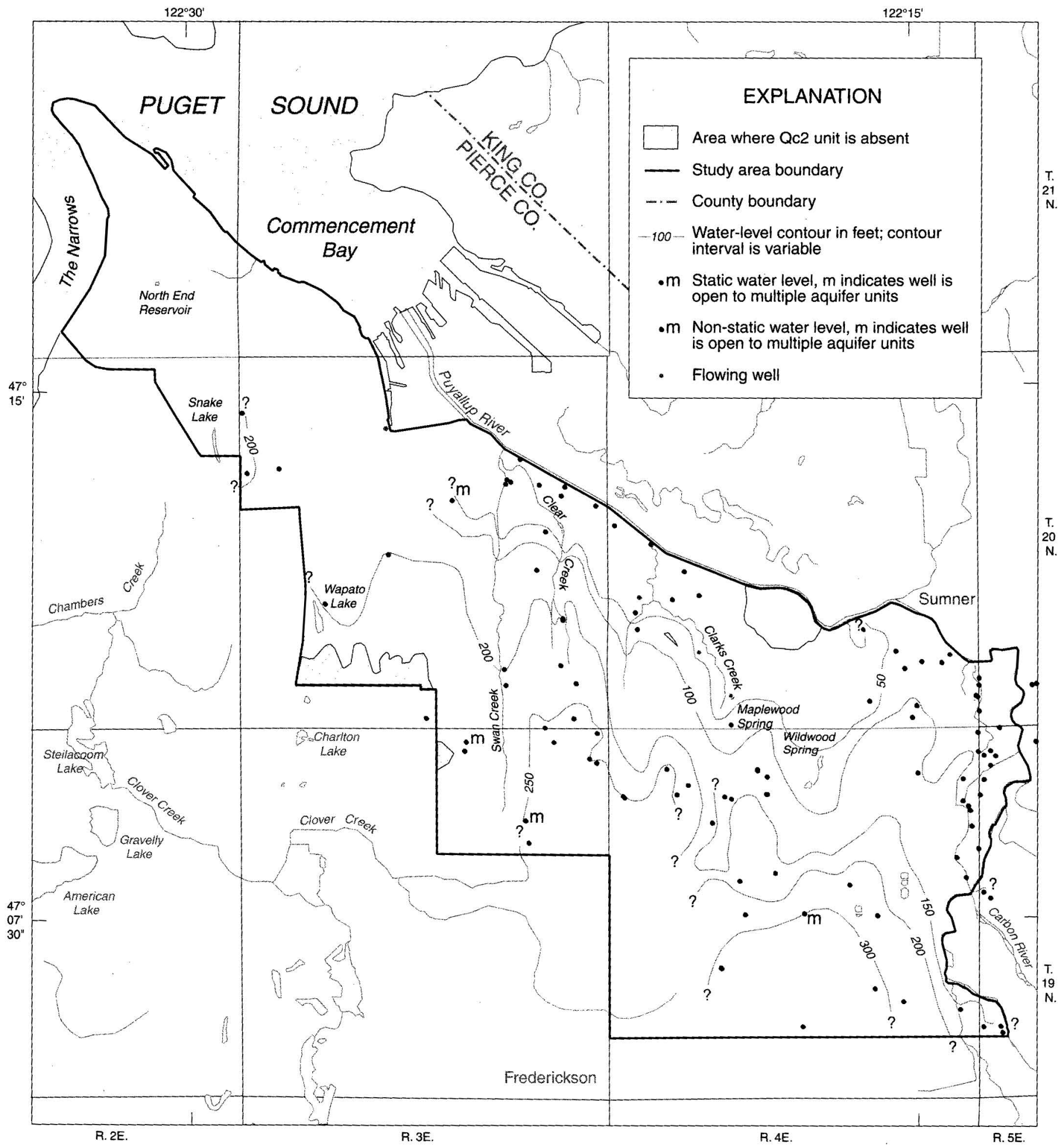

$\begin{array}{lllllll}0 & & 1 & 2 & 3 & 4 & 5 \\ 0 & 1 & 2 & 3 & 4 & 5 \text { KILOMETERS }\end{array}$ MILES

Figure 15. Water-level altitude in aquifer Qc2. Water levels were compiled from current and historical data in the TacomaPuyallup area, Washington. 
The distribution of the data for unit Qc2 was adequate for contouring water-level altitudes in the central and eastern parts of the study area, but not for the northwest part of the study area (fig. 15). The predominant directions of ground-water movement in this unit are north and east to the Puyallup River, Commencement Bay, The Narrows, and Puget Sound, but the direction of the ground-water movement near the southwest border of the study area is unknown. The lateral ground-water gradients are variable throughout the area and are greatest in the southeast corner of the study area. Gradients in this area are $150 \mathrm{ft} / \mathrm{mi}$ to the north and east toward the Puyallup River (fig. 15). In the central part of the study area, ground-water gradients are about $100 \mathrm{ft} / \mathrm{mi}$. Ground-water movement was not determined for units below Qc2 due to the sparse amount of data, although individual water-level altitudes for the deeper units, where available, are listed in appendix 1 .

Vertical flow directions are difficult to determine because extents and thicknesses of hydrogeologic units vary, a semiconfining unit may or may not be present, and data are sparse. In general the vertical flow is downward in the upland areas and upward in areas along the coast and the Puyallup River Valley. The vertical water-level altitude difference was determined by comparing waterlevel altitude contours of the two water-level maps (figs. 14 and 15). Water-level altitude differences between aquifers Qc1 and Qc2 in the southeast part of the study area where sufficient contoured data were available to make a comparison ranged from 50 to $250 \mathrm{ft}$. In the central part of the study area near Wapato Lake, two closely spaced wells, 20N/03E-20P01 and 20P02 (fig. 3) between aquifers Qc1 and Qc2 (appendix 1), indicate a difference of $30 \mathrm{ft}$. The downward vertical water-level difference decreases between the two aquifers in areas within the Puyallup River Valley and in the lowland areas along the coast. In these areas upward movement is indicated by the presence of flowing wells in aquifers Qc2 and deeper (fig. 15 and appendix 1).

\section{Water-Level Fluctuations}

Ground-water levels fluctuate over time, both seasonally and long term, in response to changes in recharge to and discharge from the ground-water system. When recharge exceeds discharge, water levels will rise, and where discharge exceeds recharge, water levels will decline.

Ground-water levels fluctuate seasonally mostly because of the variations in recharge during the year. In general, water levels in shallow wells in western
Washington rise from October through March, when precipitation is high, and decline from April through September, when precipitation is low. Water levels in deep wells generally respond more slowly, and usually with less change, than water levels in the shallow wells. The magnitude and timing of the seasonal water-level fluctuations in an aquifer in response to precipitation are related to the variation in ground-water recharge, the depth to the water table, the depth of the aquifer, the kind of aquifer, confined or unconfined, and the hydraulic characteristics of both the aquifer and the hydrogeologic units that may overlie it. Water-level fluctuations caused by fluctuations in precipitation are also influenced by river or lake changes due to the proximity of the well to the surface-water bodies. Other factors affecting the magnitude of water-level fluctuations in a well are pumping of the well or pumping from nearby wells.

Water levels and specific conductance, where possible, were measured bimonthly in 36 wells for a period of 2 years (fig. 16, and 17a through $17 \mathrm{e}$, and table 5). These wells were completed in hydrogeologic units Qvr, Qvt, $\mathrm{Qc1}$, Qc2, and Qc3, and their depths range from $11.1 \mathrm{ft}$ to $573 \mathrm{ft}$. They were grouped by well depth in $100-\mathrm{ft}$ intervals, except the last group, which is $200 \mathrm{ft}$, for the purpose of discussion.

The number of wells, the range of well depths, the range and median values of the individual water-level fluctuations and specific conductance, and the hydrogeologic units in which wells in each group are completed, are shown in table 5 for the 1996 water year. This water year was chosen because the aquifer testing in 1995 in the Tacoma well field just outside the study area near the South Tacoma Channel (fig. 16) may have partially affected nearby observation wells. During the period of June 14, 1995, until September 18, 1995, approximately $17.4 \mathrm{Mgal} / \mathrm{d}$ (million gallons per day) were pumped continuously from five wells located in the Tacoma well field (AGI Technologies, 1998).

In general, the water levels in all the observation wells reflect the seasonal variation in precipitation. But the expected decrease in the amount of water-level change in individual wells with increasing depth is not seen in the water-level data collected from this group of observation wells (table 5). In fact several water-level fluctuations appeared to increase with depth. This is probably because most of the wells that are completed at depth (figs. 17b, c, $\mathrm{d}$, and e) were being pumped. Conversely, most of the shallow wells (fig. 17a) are unused, and the water-levels in them are unaffected by pumping. 


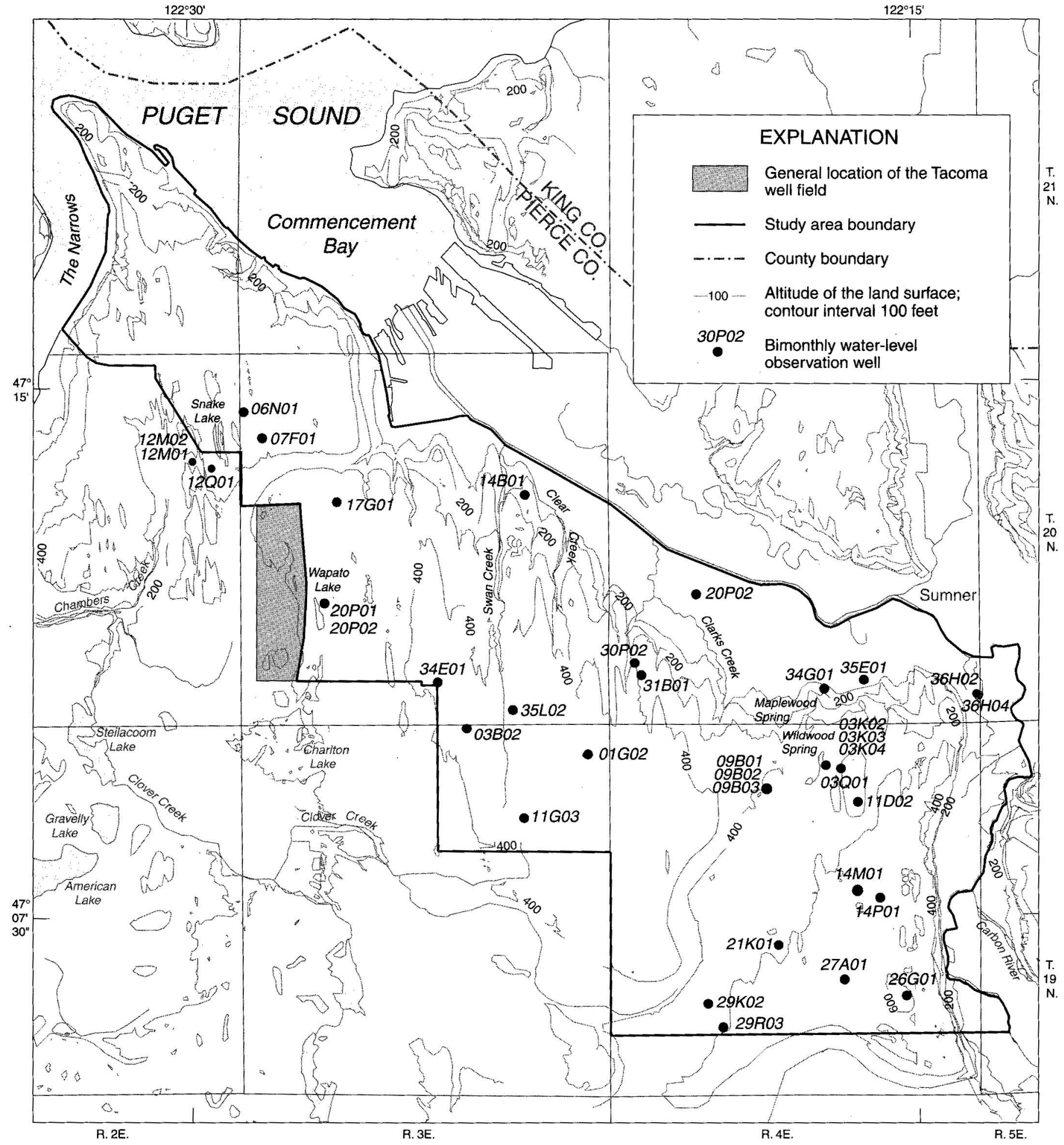

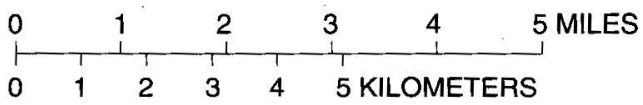

Figure 16. Locations of bimonthly water-level observation wells in the Tacoma-Puyallup area, Washington. 


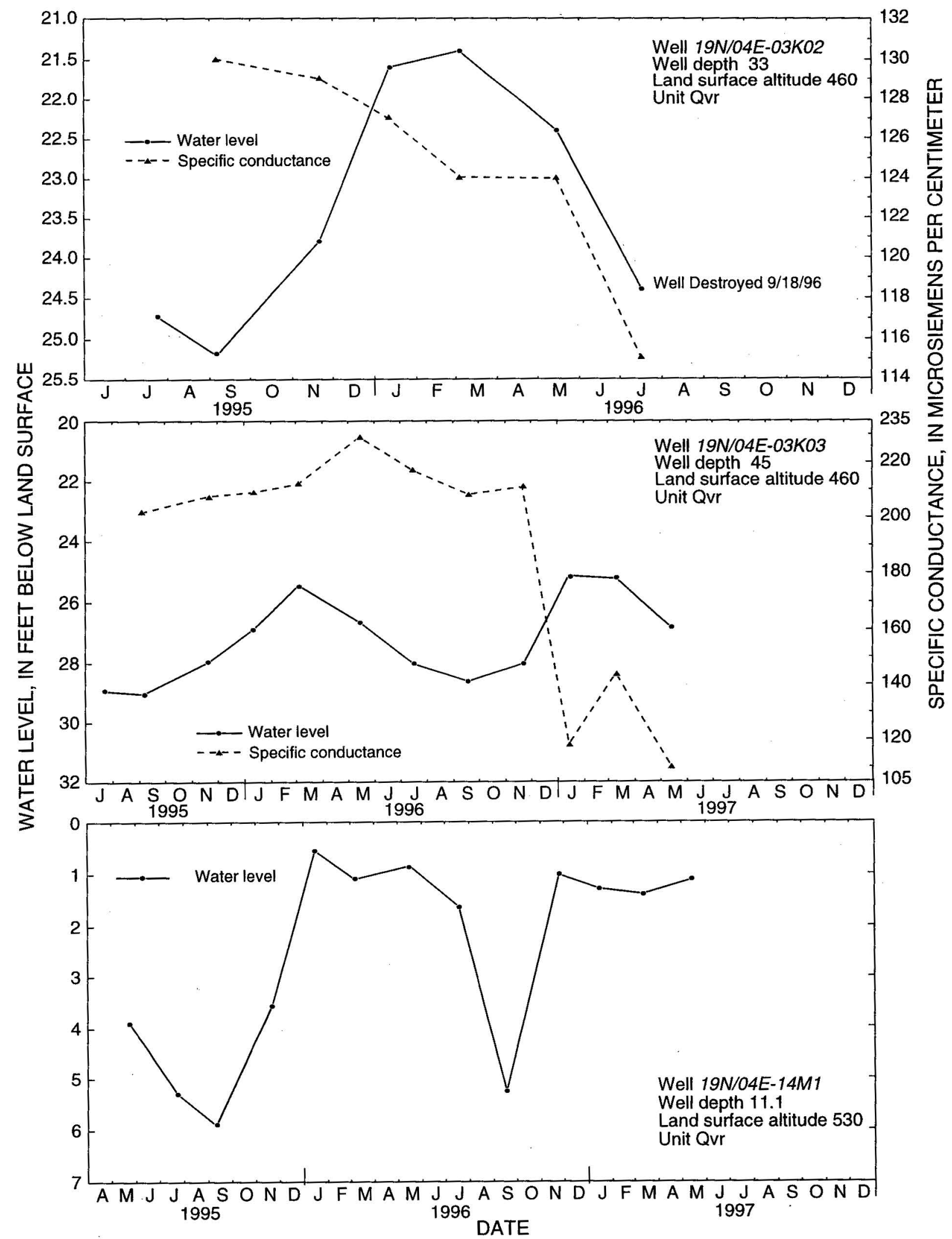

Figure 17a. Water levels and where available, specific-conductance measurements for the bimonthly observation wells $0-100$ feet deep in the Tacoma-Puyallup area, Washington. See figure 16 for well locations. 


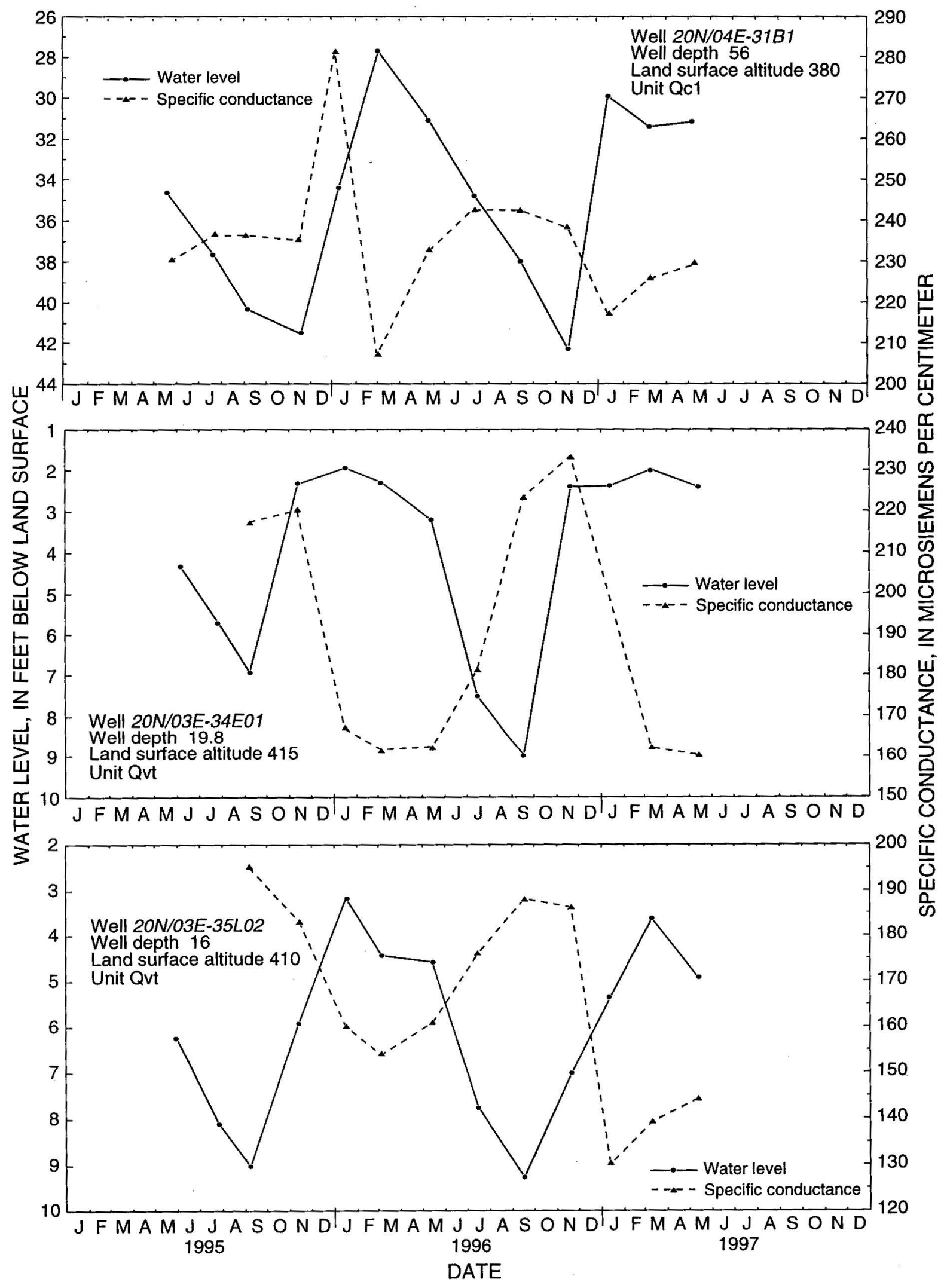

Figure 17a. Continued 


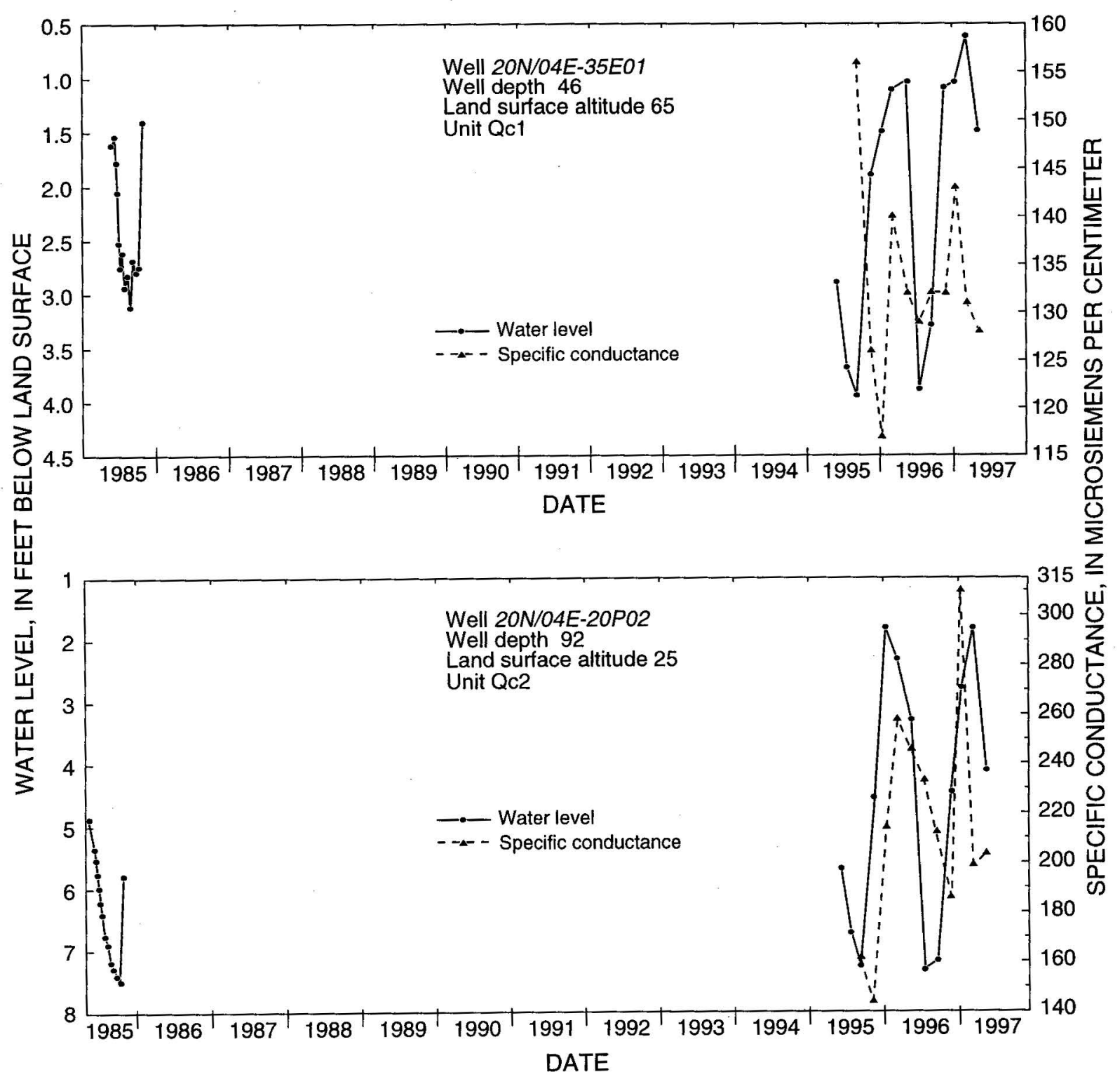

Figure 17a. Continued 


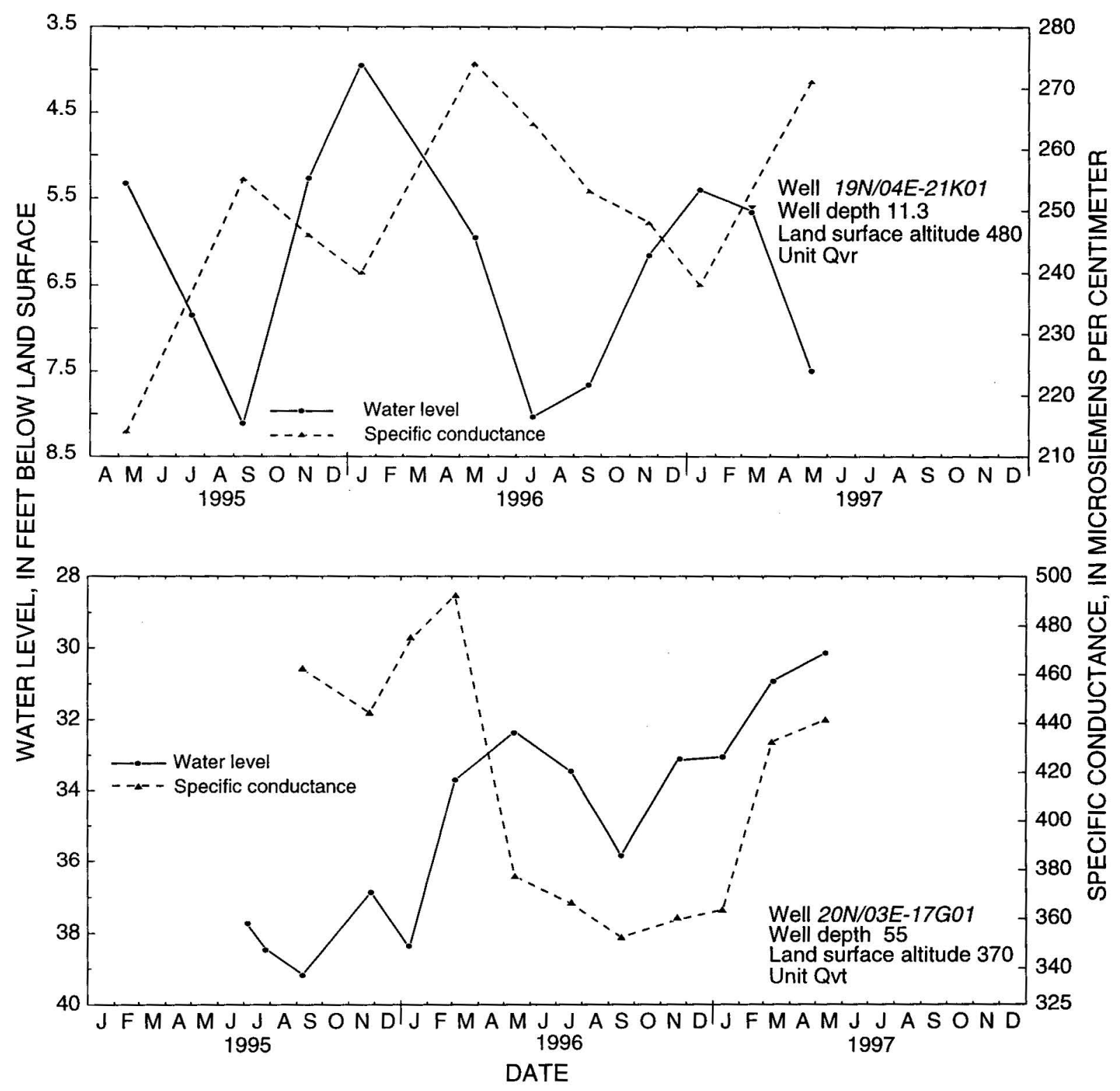

Figure 17a. Continued 


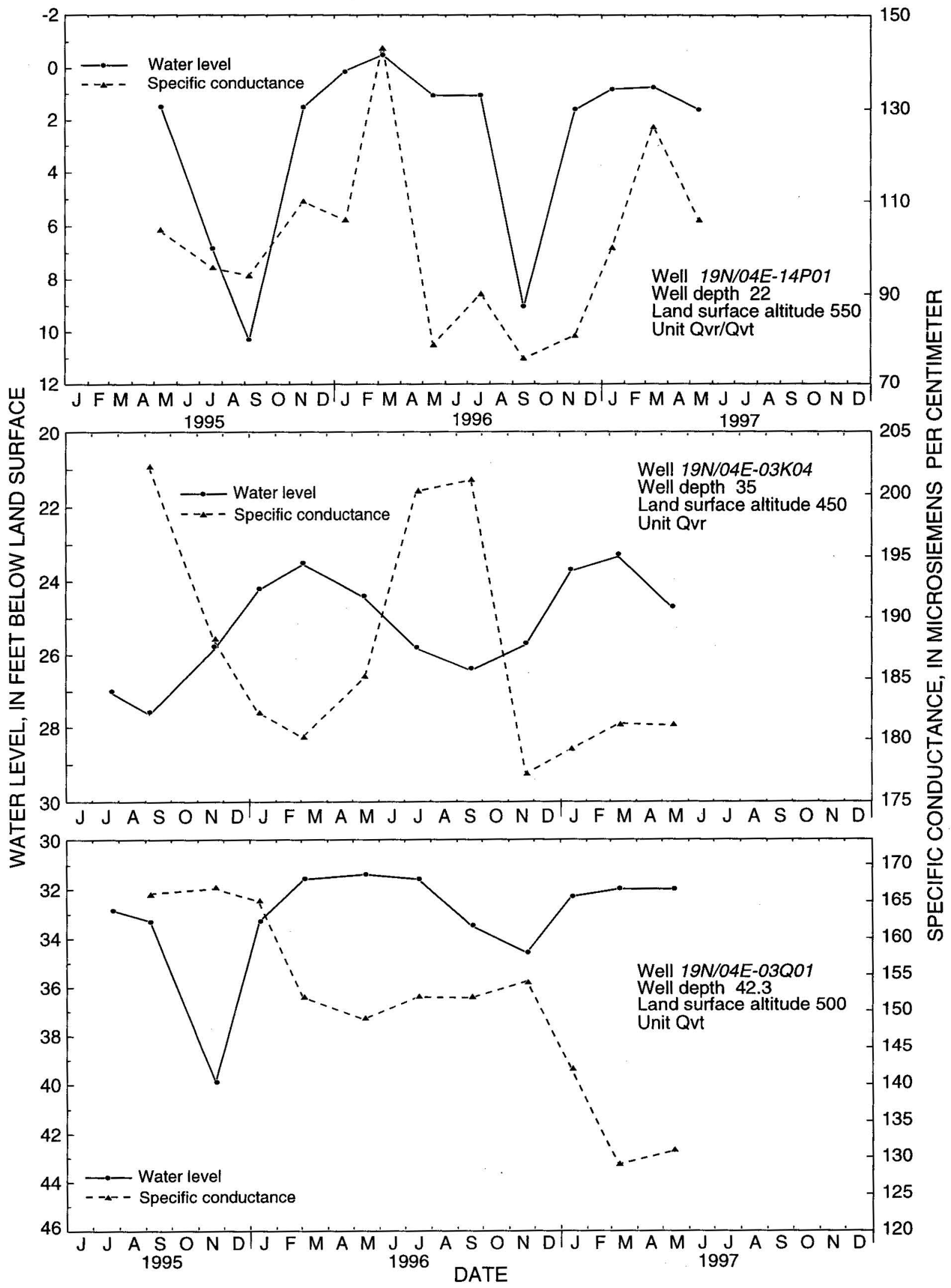

Figure 17a. Continued 


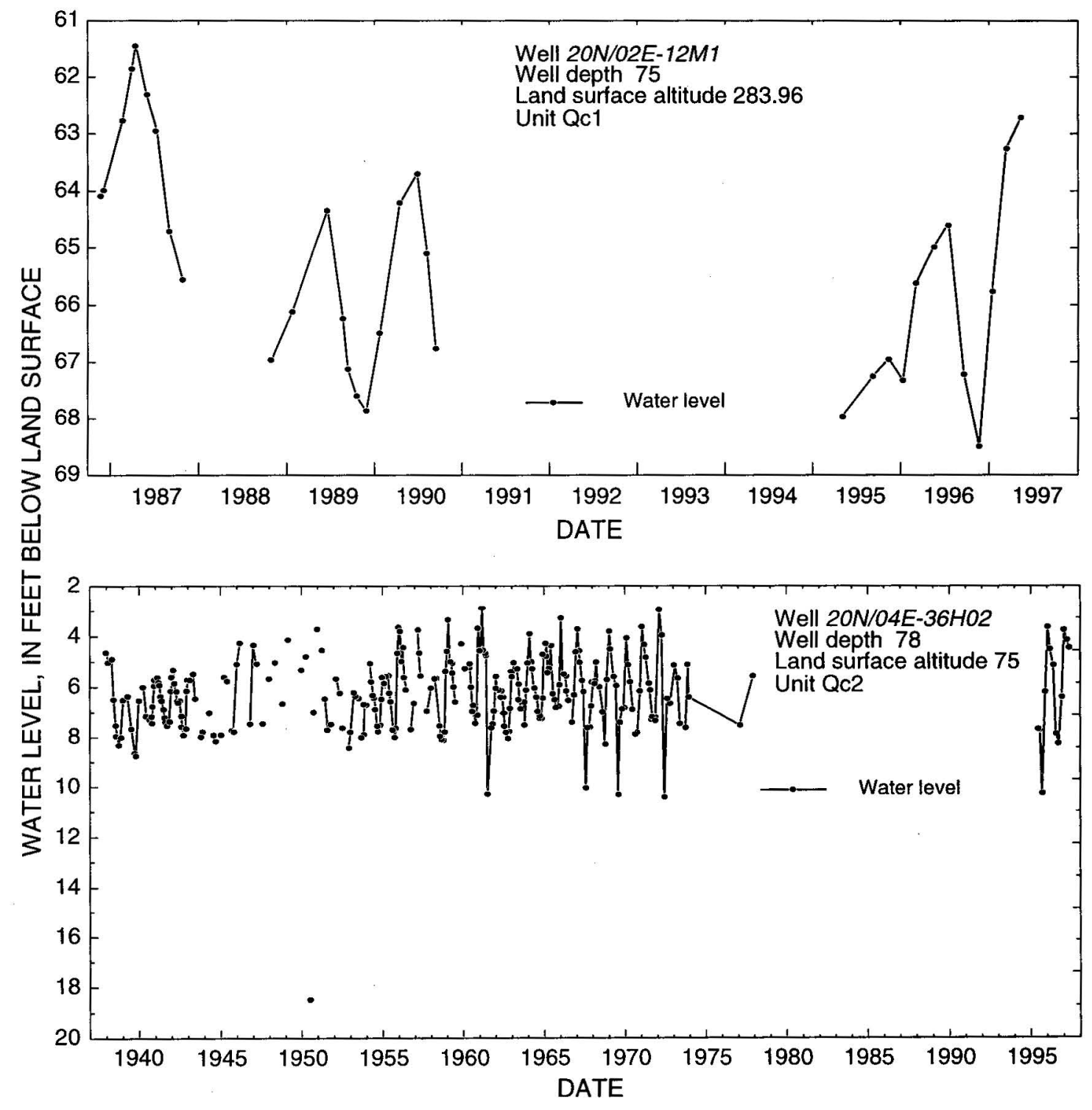

Figure 17a. Continued 


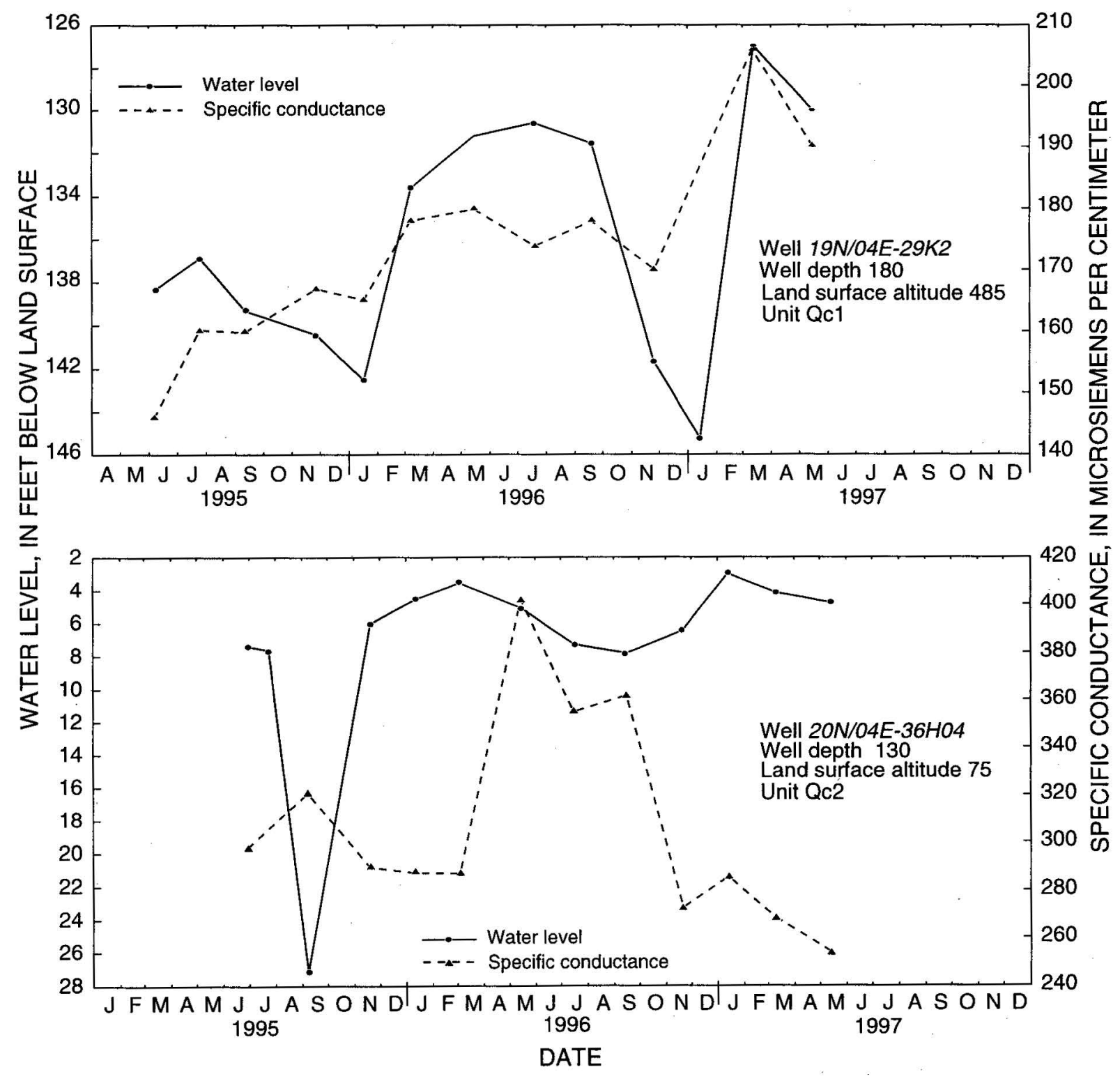

Figure 17b. Water-levels and where available, specific-conductance measurements for the bimonthly observation wells $101-200$ feet deep in the Tacoma-Puyallup area, Washington. See figure 16 for well locations. 


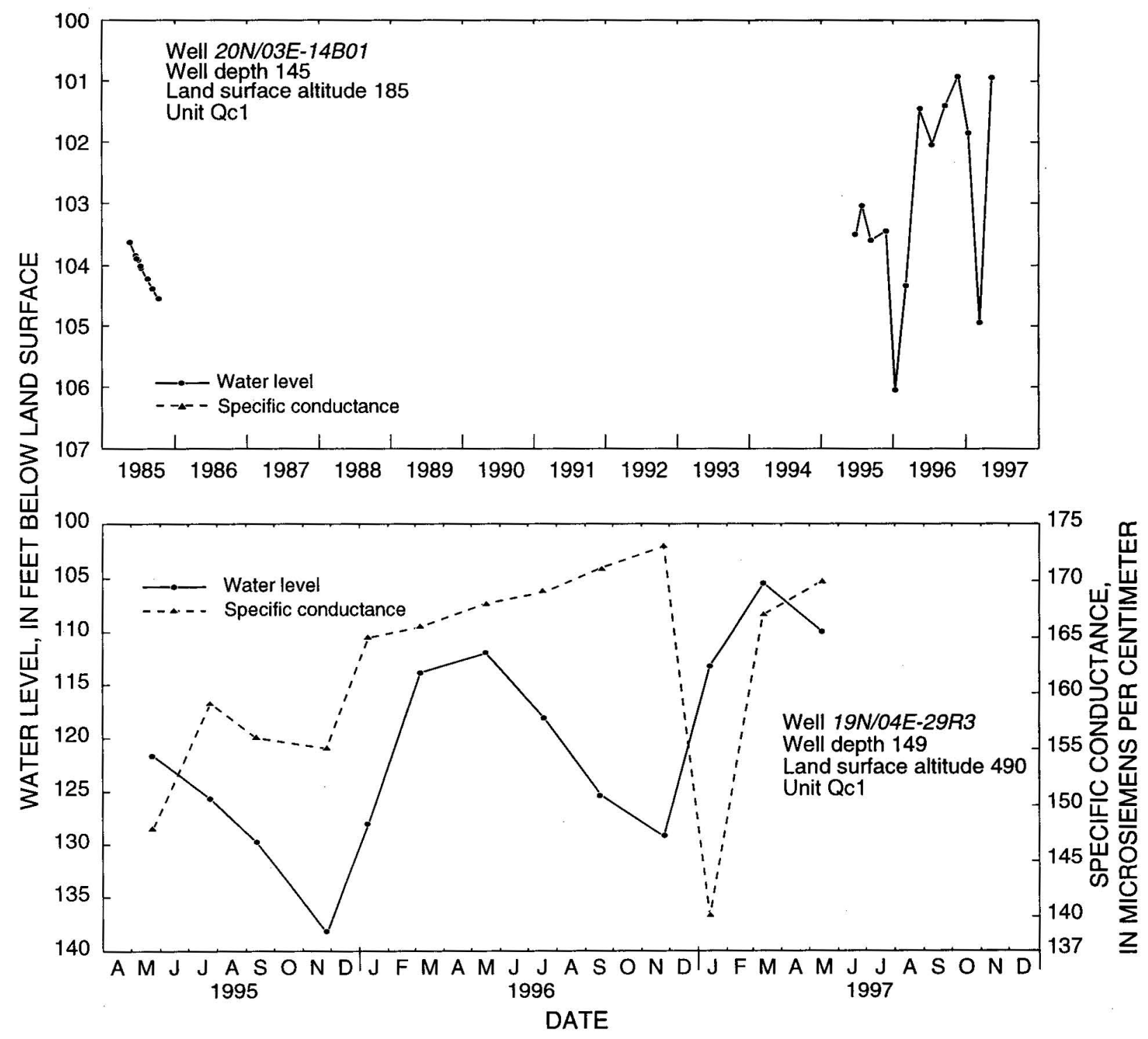

Figure 17b. Continued 


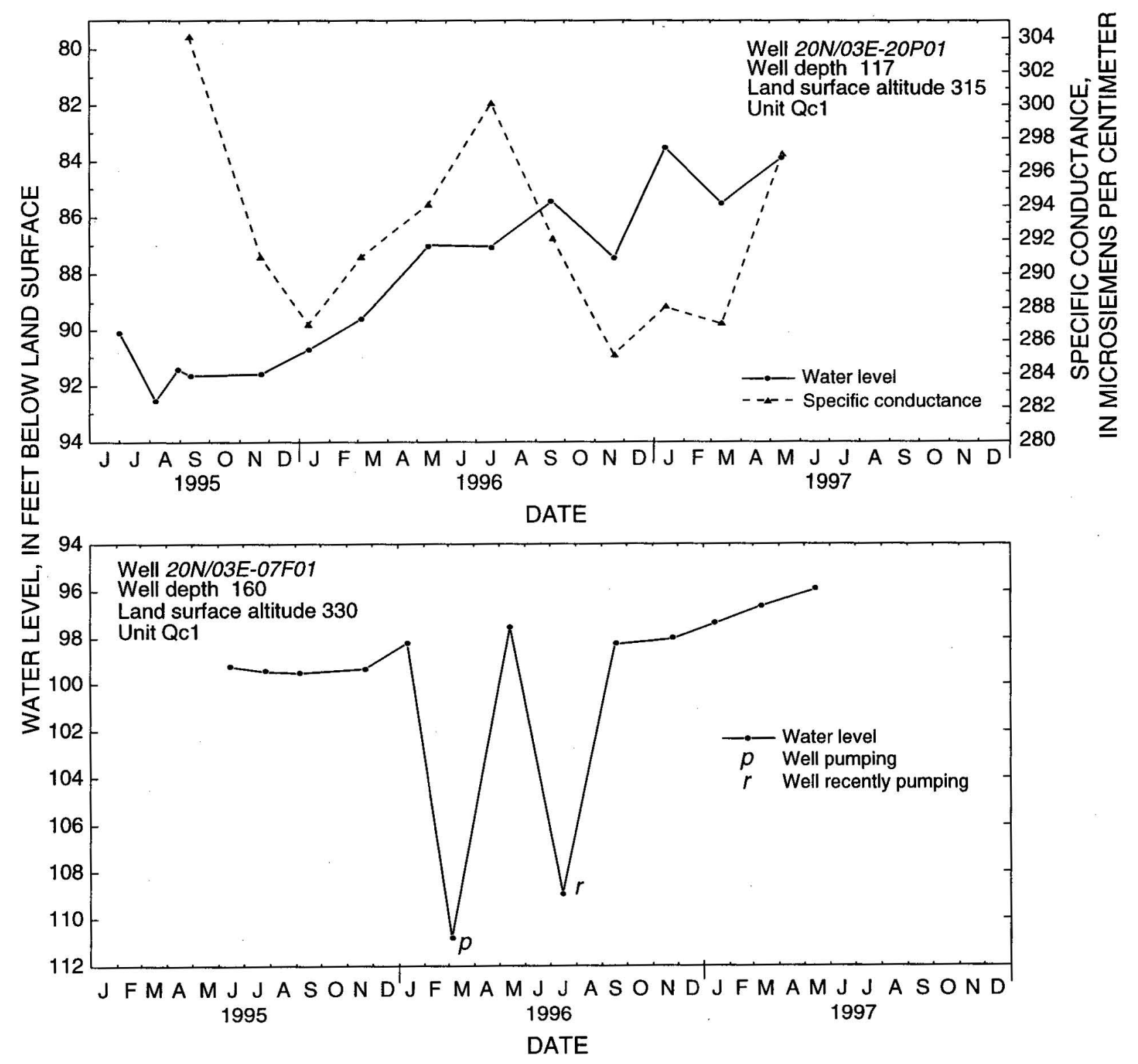

Figure 17b. Continued 


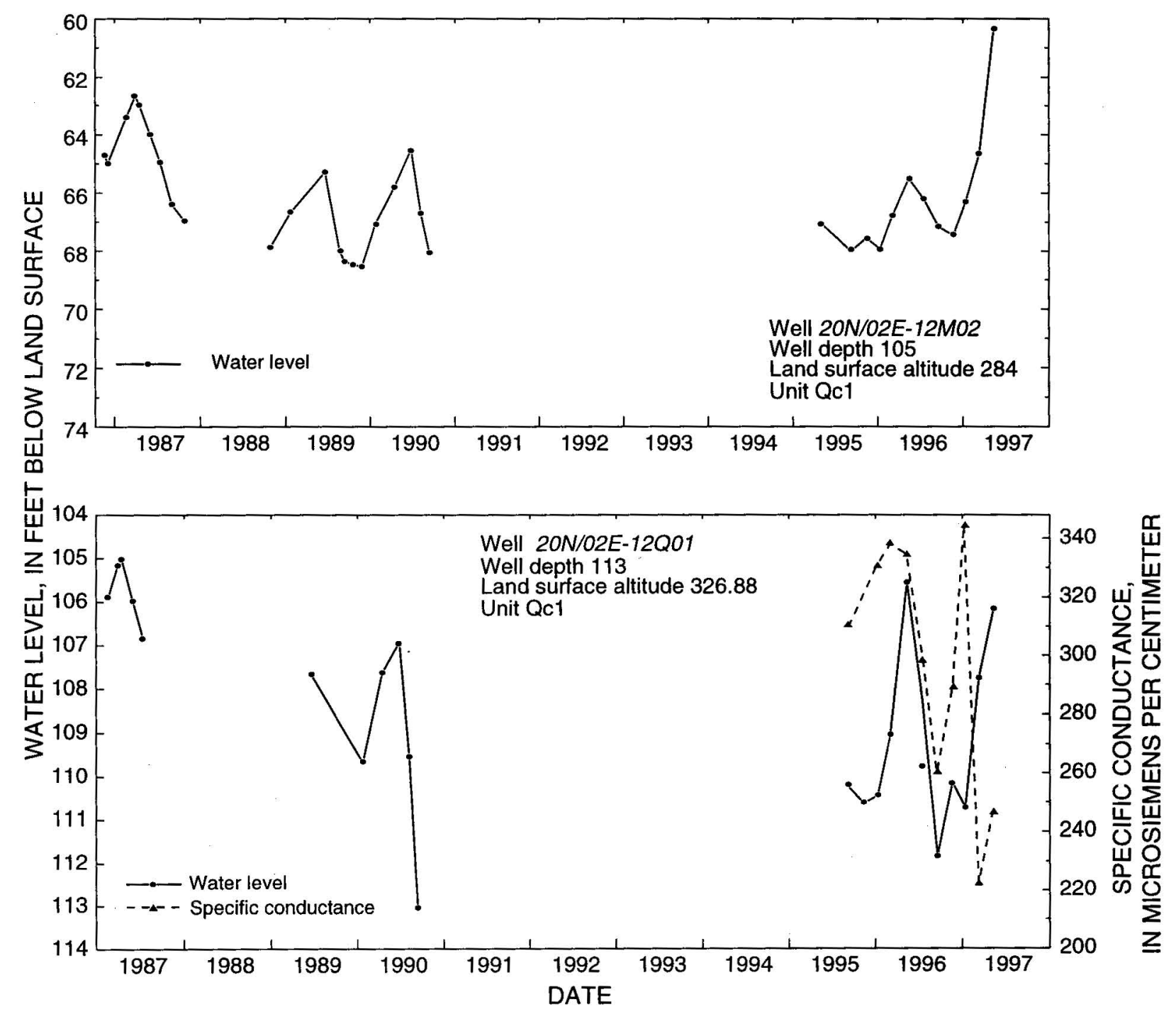

Figure 17b. Continued 


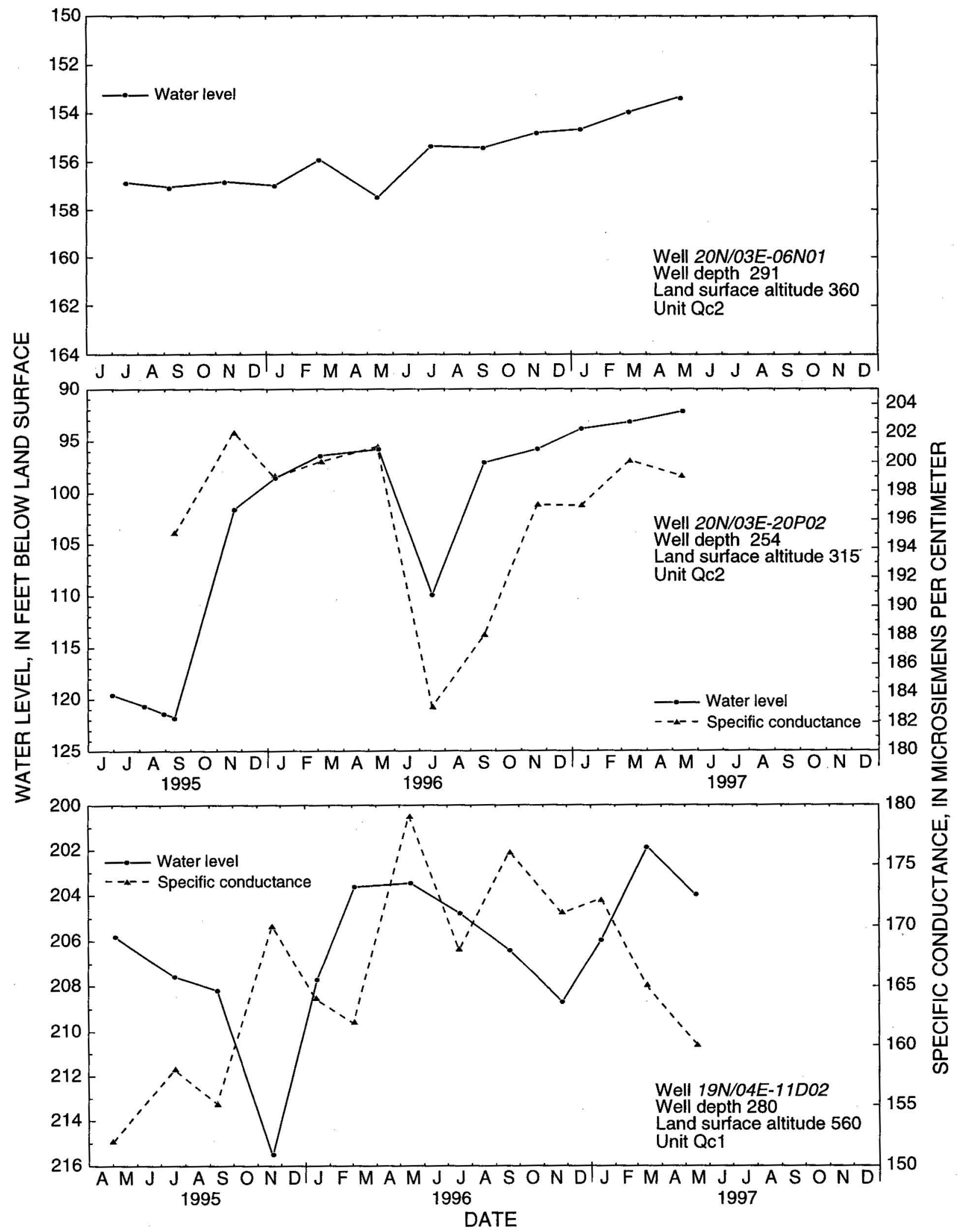

Figure 17c. Water levels and where available, specific-conductance measurements for the bimonthly observation wells 201 - 300 feet deep in the Tacoma-Puyallup area, Washington. See figure 16 for well locations. 


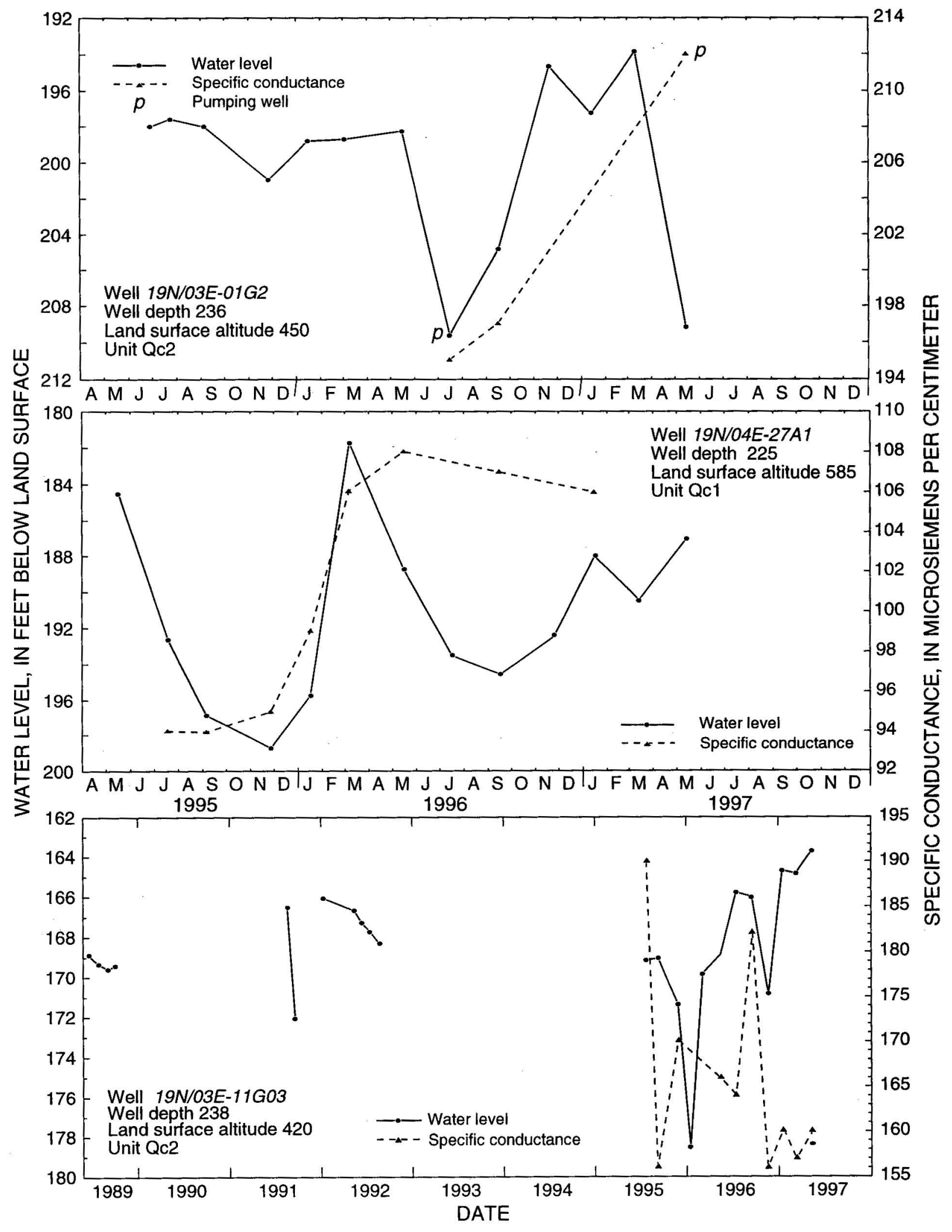

Figure 17c. Continued 


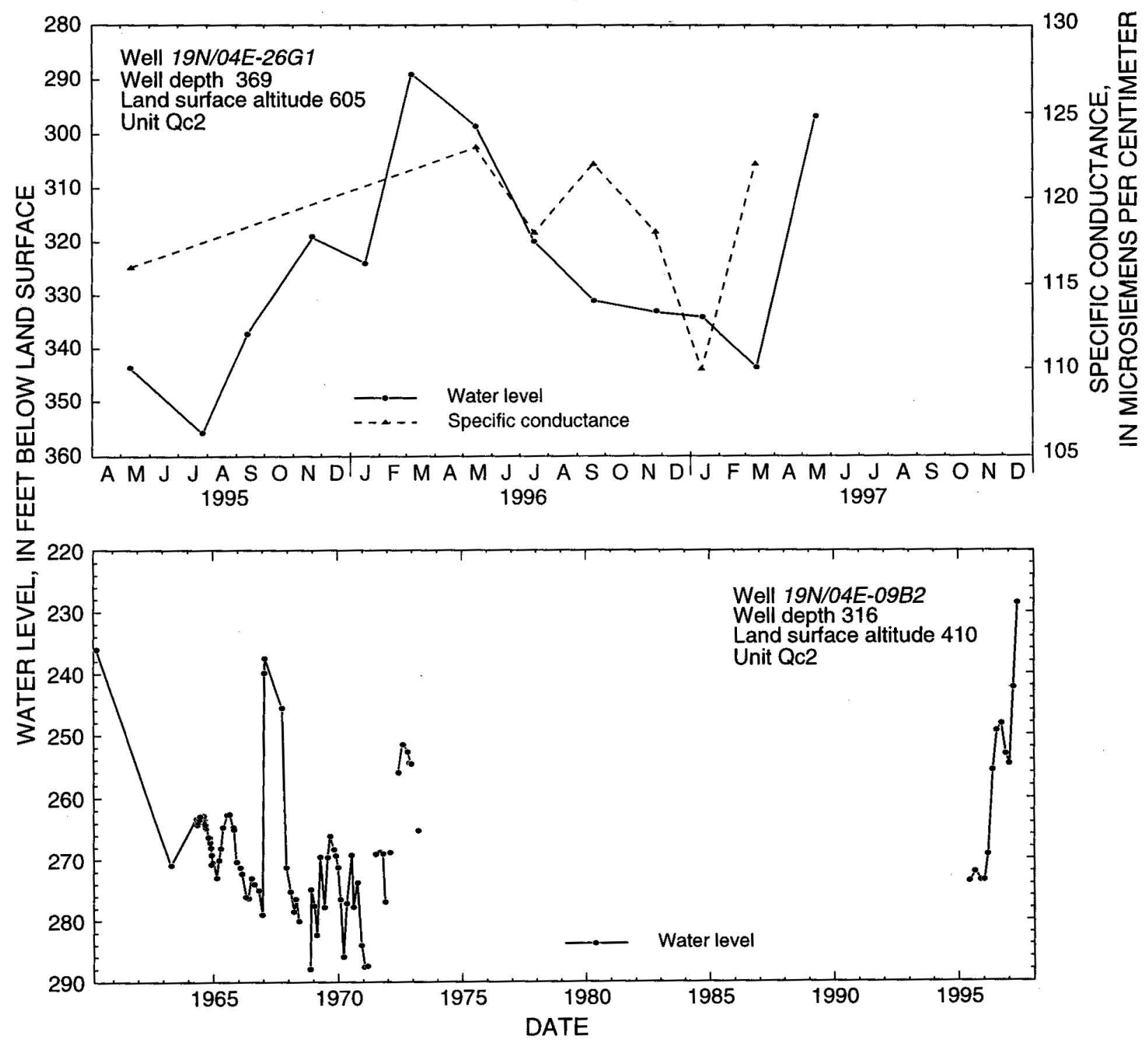

Figure 17d. Water levels and where available, specific-conductance measurements for the bimonthly observation wells 301 - 400 feet deep in the Tacoma-Puyallup area, Washington. See figure 16 for well locations. 


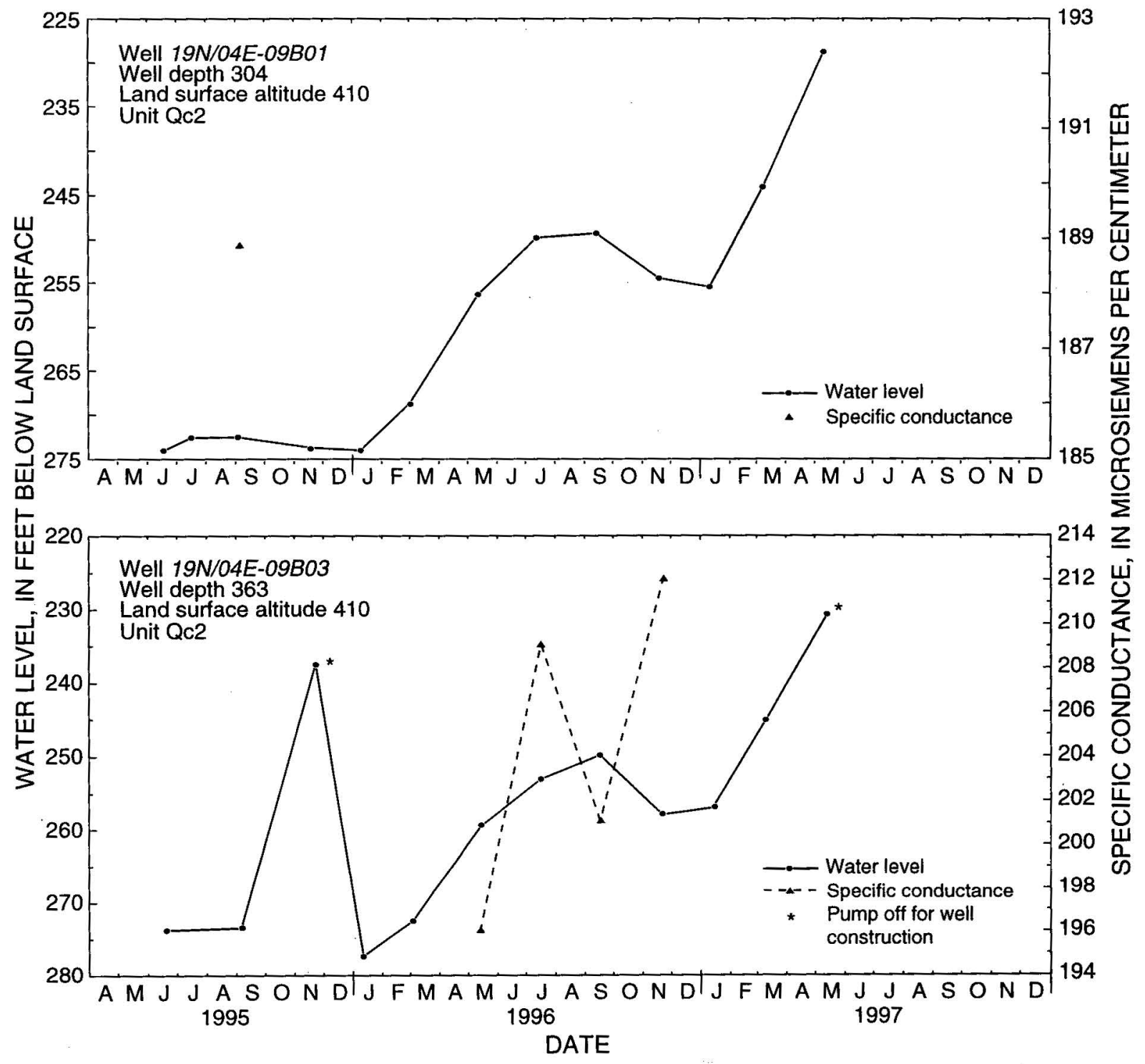

Figure 17d. Continued 


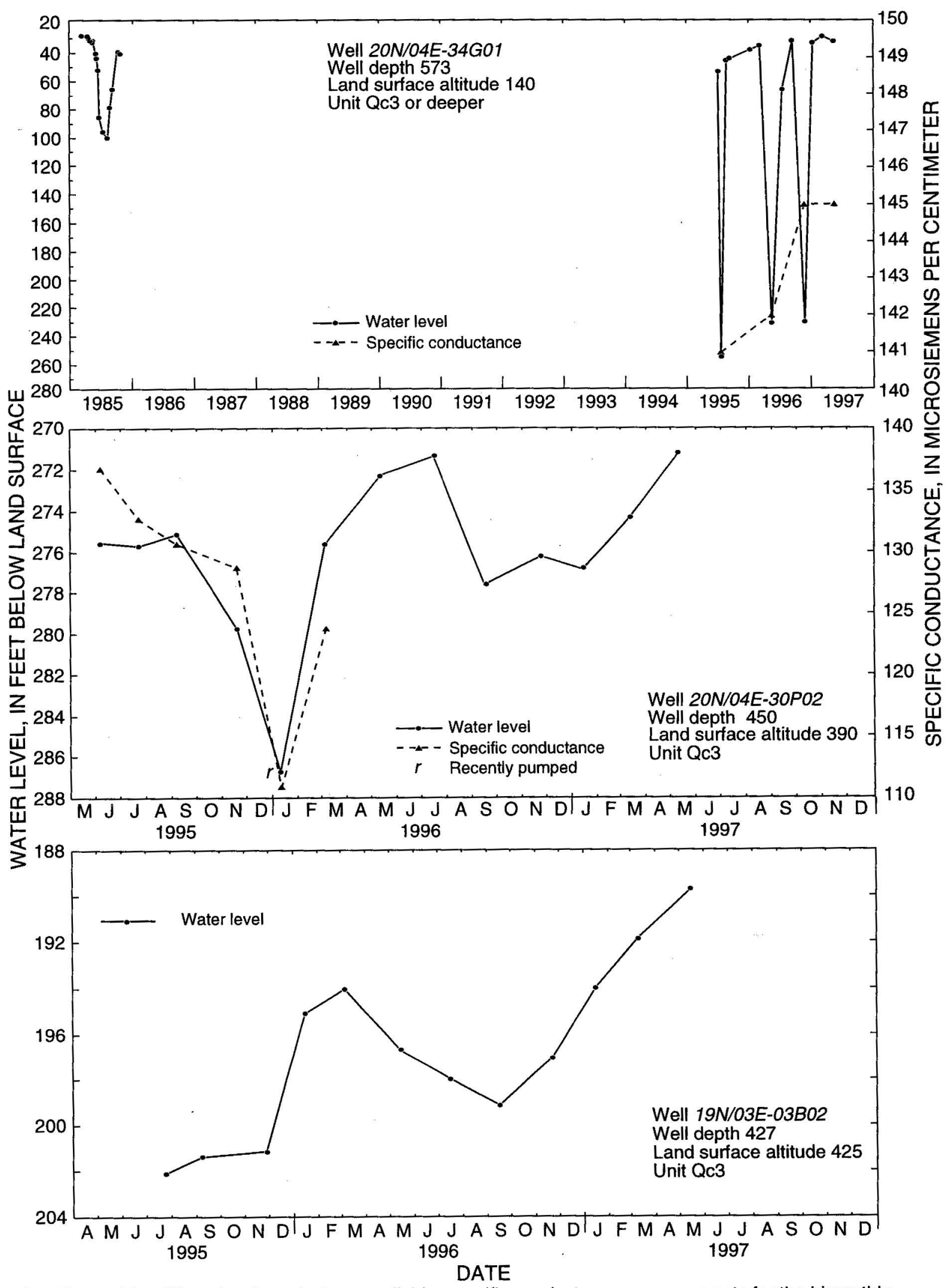

Figure 17e. Water levels and where available, specific-conductance measurements for the bimonthly observation wells 401 - 600 feet deep in the Tacoma-Puyallup area, Washington. See figure 16 for well locations. 
Table 5.--Summary of water-level and specific conductance data for the 1996 water year in the Tacoma-Puyallup area, Washington $[--$, no data; $\mu \mathrm{S} / \mathrm{cm}$, microsiemens per centimeter]

\begin{tabular}{|c|c|c|c|c|c|c|c|c|c|}
\hline \multirow{2}{*}{$\begin{array}{l}\text { Number } \\
\text { of wells }\end{array}$} & \multirow{2}{*}{$\begin{array}{l}\text { Range of } \\
\text { well depth } \\
\text { (feet) }\end{array}$} & \multicolumn{3}{|c|}{ Water-level change, in feet } & \multicolumn{3}{|c|}{ Specific conductance change, $\mu \mathrm{S} / \mathrm{cm}$} & \multirow{2}{*}{$\begin{array}{l}\text { Hydrogeologic } \\
\text { units }\end{array}$} & \multirow{2}{*}{$\begin{array}{l}\text { Figure } \\
\text { number }\end{array}$} \\
\hline & & Minimum & Median & Maximum & Minimum & Median & Maximum & & \\
\hline 15 & $11.1-92$ & 2.77 & 5.12 & 13.82 & 18 & 34 & 114 & Qvr, Qvt, Qc1, Qc2 & $17 \mathrm{a}$ \\
\hline 8 & $105-180$ & 2.41 & 6.23 & 26.32 & 13 & 16 & 115 & Qc1 and Qc2 & $17 \mathrm{~b}$ \\
\hline 6 & $225-291$ & 1.54 & 12.4 & 17.03 & 6 & 16 & 17 & Qc1 and Qc2 & $17 \mathrm{c}$ \\
\hline 4 & $304-369$ & 24.68 & 33.44 & 42.19 & 13 & -- & -- & Qc2 & $17 \mathrm{~d}$ \\
\hline 3 & $427-573$ & 7.12 & 15.38 & $199.61 p$ & 13 & -- & -- & Qc3 & $17 \mathrm{e}$ \\
\hline
\end{tabular}

p Water-level difference is based on a pumping water level. 
Seasonal changes in specific conductance values are generally greatest in the shallow wells and decrease with increasing well depth (table 5). Because the specific conductance of the newly recharging precipitation is less than that of the older ground water that has been in contact with minerals in the aquifer, as the precipitation increases and water levels in shallow wells rise, specific conductance values will decrease. In shallow wells the specific conductance value generally decreases at the same time as the water level increases (fig. 17a). As the depth of the wells increases, so does the time between the increase in the water-level and the decrease in the specific conductance (figs. 17b, c, d, and e).

Data from four wells, 20N/03E-17G01, 20N/03E06N01, 20N/03E-20P01, and 20N/03E-20P02 show a net increase in water levels from 1995 to 1996 (fig. 17a, b, and c). This may be due to an increase in precipitation from 1995 to 1996, or it could be a recovery of water levels following the 1995 aquifer tests in the Tacoma well field.

Ground-water levels may fluctuate over time due to long-term changes in recharge or discharge. These changes may be natural, such as a long-term drought, or due to changes in land-use practices or increased withdrawals from wells. Whatever the cause, over the long term the ground-water system will establish a new equilibrium by adjusting its water levels to balance the changes in the recharge and discharge. When USGS personnel inspected and compared the historical water levels with the water levels measured during this study, no long-term trends were evident in the ground-water system.

Historical data were available for 10 wells, 20N/04E20P2, 35E1, 36H2, and 20N/02E-12M1 (fig. 17a); 20N/03E-14B01, 20N/02E-12M02 and 12Q01 (17b); 19N/03E-11G03 (17c); 19N/04E-09B02 (17d); and 20N/04E-34G01 (17e). There appears to be no long-term trend in the water levels in wells 19N/04E-9B02, 20N/04E-36H2 or 20N/04E-20P2. However, two of these wells are located near surface-water bodies. Water levels in well 36H02, located in the Puyallup River Valley, are probably affected by the stage of the river, and water levels in well 20P2, located near Wapato Lake (fig. 16), may be influenced by changes in the lake stage. Insufficient data and the large variation in the data for wells 35E01, 11G03, and 34G01 make it difficult to determine if the data indicate any long-term trends. Wells $12 \mathrm{M} 1$, $12 \mathrm{M} 2$, and $12 \mathrm{Q} 1$ indicate a water-level decline of about $2 \mathrm{ft}$ between 1987 and 1989, but do not indicate any long-term trend in the ground-water levels.

\section{Ground-Water Discharge}

Ground water in the study area discharges naturally as seepage to streams, lakes, cliff faces, wetlands, and springs, and as ground-water movement out of the area. It is also discharged to man-made systems such as sanitary and stormwater systems and by withdrawal from water wells. Only a small part of discharge was quantified during this study. This includes estimates of the quantity of water discharged to streams and springs and the quantity of water withdrawn from wells.

\section{Natural Discharge}

Ground-water discharge sustains the late summer flow, baseflow, of creeks within the study area. Estimates of baseflow were made on three gaged creeks--Swan, Clear, and Clarks Creeks--whose basin boundaries are contained within the study area, and the estimated baseflows were $0.5,8$, and $45 \mathrm{ft}^{3} / \mathrm{s}$ (cubic feet per second), respectively. The baseflow values were estimated from hydrographs of the mean daily discharge data for the 1996 water year (U.S. Geological Survey, 1996) at each of the three continuous gaging stations (locations shown on fig. 1). The ground-water discharge from baseflow to each of the three creeks is considered a minimum discharge value, due to location of the gages and the limited ability to estimate baseflow determined solely on discharge hydrographs. Data were not collected nor were sufficient data available to make reasonable estimates of groundwater discharge to Clover and Chambers Creeks, the Puyallup River, or to ground-water inflow and outflow across the southwest study area boundaries.

Discharge and specific conductance were measured, generally during the spring and fall, at 18 springs (table 6). Discharge from many small- to moderate-size springs throughout the study area was not quantified, and the combined discharge from these springs is unknown. There were also no data available to quantify the groundwater discharge and evaporation from seepage faces along the steep cliff faces in the study area.

An attempt was made to measure discharge from all springs measured by Walters and Kimmel (1968). Some of these springs measured during this period have since been physically destroyed or could not be located, and some previously unmeasured springs were added. Spring discharge measured during this study, with the exception of Maplewood Spring, ranged from 4 to $280 \mathrm{gal} / \mathrm{min}$ 
(gallons per minute), with a median of $49 \mathrm{gal} / \mathrm{min}$ and a total discharge of $1,525 \mathrm{gal} / \mathrm{min}$ during the summer and fall of 1995 . During the spring of 1995 , discharge ranged from 12 to $1,800 \mathrm{gal} / \mathrm{min}$, with a median of $120 \mathrm{gal} / \mathrm{min}$ and a total discharge of $5,134 \mathrm{gal} / \mathrm{min}$ (table 6). Most of this discharge is assumed to be from the shallow groundwater system because the differences between specific conductance values measured in the spring and fall are small.

\section{Water Use}

In addition to natural discharge, water from surfaceand ground-water sources is withdrawn within the study area for drinking water and for commercial, industrial, agriculture, aquaculture, and irrigation uses. During the 1996 water year, 22,100 million gallons of water were withdrawn to supply the study area's needs. This quantity of water represents a gross withdrawal and does not take into account the quantity of water that is returned to the ground-water system through septic systems or deep percolation of irrigation water. It is unlikely that all water users within the study area were contacted, so all wateruse totals probably represent minimum values. Of the 22,100 million gallons, 69 percent $(15,200$ million gallons) was imported from surface-water sources outside the study area, and 31 percent (6,890 million gallons) was from ground water withdrawn within the study area (this includes wells and springs). Of the 6,890 million gallons used, 2.6 percent (179 million gallons) was imported from ground-water sources outside the study area. A summary of water used during the 1996 water year for the study area, compiled by water use, source of water (well, spring, or surface), and hydrogeologic units, is presented in table 7.

Commercial and industrial water use accounted for 42 percent (9,320 million gallons) of the water used in the study area, making it the largest water use. Water was supplied by public-supply systems as well as by commercial and industrial owners with private wells. Most water used for commercial and industrial purposes, 89.7 percent (8,360 million gallons), came from surface-water sources. Aquifer Qc1 supplied the largest amount of ground water, 6 percent (559 million gallons), for commercial and industrial purposes.

The second largest use of water during the 1996 water year within the study area was for public supply. Both metered and estimated system totals combined, including 8 group A water systems and 12 group B water systems, accounted for 37 percent $(8,160$ million gallons) of all the water used within the study area. Public-supply systems provided water to about 75 percent of the population $(172,000$ people) within the study area. The largest part of public-supply water was imported from a surfacewater source outside the study area, providing 63 percent $(5,160$ million gallons) of the total public supply. Groundwater sources provided the remaining 37 percent $(3,000$ million gallons), of which 98 percent ( 2,930 million gallons) was from ground-water sources within the study area, and 2 percent ( 66.0 million gallons) was from ground-water sources outside the study area. Aquifer Qc1 supplied 47 percent (1,410 million gallons) of the total water withdrawn from the ground-water sources.

Water withdrawn from privately owned wells or springs for domestic water use was estimated at 8.7 percent ( 1,920 million gallons) of the total water use. These sources supplied 25 percent of the water used by the population within the study area. Aquifer Qc2 supplied 43 percent (826 million gallons), and aquifer Qc1 supplied 34 percent (660 million gallons) of the water used for domestic purposes (table 7).

Public-supply loss includes water lost to pipe breakage, leaks, flushing of lines and water for municipal purposes, for example, fire department use. Water-loss estimates were available only from the public-supply systems. Water loss from both metered and estimated public-supply systems was estimated at 8 percent (1,690 million gallons) of the total water use.

Agricultural and aquacultural water use within the study area accounts for 2.8 percent ( 619 million gallons) of the total water used. Agricultural estimates were based on information from owners on the number and type of livestock maintained. Estimates were then calculated from this information by multiplying the number of animals by the average amount of water used per year for each animal type. Aquacultural estimates were calculated from the number of fish raised and the average amount of water needed to raise each fish. Although aquacultural water use is largely nonconsumptive, it is included as a withdrawal from the system because the quality and location of the water is altered. Ground-water withdrawals from aquifer Qc3 provided over 90 percent (562 million gallons) of the agricultural and aquacultural water used (table 7).

Water withdrawn for irrigation purposes accounted for less than 1 percent (104 million gallons) of the total water used in the study area during 1996 . Irrigation supplies were predominately withdrawn from aquifers Qc2, supplying 78 percent (81.4 million gallons), and 
Table 6.--Records of springs inventoried for this study during 1995 and 1996 in the Tacoma-Puyallup area, Washington [Altitude: interpolated from topographic maps; Use: H, domestic, U, unused, P, public supply; gpm, gallons per minute; $\mu \mathrm{S} / \mathrm{cm}$, microsiemens per centimeter; RR, railroad, gal/day, gallons per day; --, no data]

\begin{tabular}{|c|c|c|c|c|c|c|c|c|}
\hline Spring number & Owner & $\begin{array}{l}\text { Altitude } \\
\text { (feet) }\end{array}$ & $\begin{array}{l}\text { Discharge } \\
\text { (gpm) }\end{array}$ & $\begin{array}{l}\text { Date } \\
\text { inven- } \\
\text { toried }\end{array}$ & $\begin{array}{l}\text { Specific } \\
\text { conductance } \\
(\mu \mathrm{S} / \mathrm{cm})\end{array}$ & $\begin{array}{l}\text { Temperature } \\
\text { (degrees C) }\end{array}$ & Use & Remarks \\
\hline 19N/04E-01D01S & Ziemke, Pete & 320 & $\begin{array}{r}40 \\
105\end{array}$ & $\begin{array}{l}10 / 24 / 95 \\
03 / 19 / 96\end{array}$ & $\begin{array}{l}556 \\
318\end{array}$ & $\begin{array}{r}10.5 \\
9.0\end{array}$ & - & Near Crystal Ridge Drive \\
\hline $19 \mathrm{~N} / 04 \mathrm{E}-12 \mathrm{~N} 01 \mathrm{~S}$ & Valley Water District & 300 & $\begin{array}{r}136 \\
1,800\end{array}$ & $\begin{array}{l}10 / 23 / 95 \\
03 / 19 / 96\end{array}$ & $\begin{array}{l}345 \\
306\end{array}$ & $\begin{array}{l}9.5 \\
9.5\end{array}$ & $\mathrm{U}$ & $\begin{array}{l}\text { Shutdown by Department of Health due to high } \\
\text { fecal coliform. WSB }-22^{\mathrm{a}}\end{array}$ \\
\hline 19N/04E-13D01S & Valley Water District & 295 & - & $10 / 23 / 95$ & -- & -- & $\mathrm{U}$ & $\begin{array}{l}\text { Destroyed. Current owner has no knowledge } \\
\text { of spring. WSB- } 22^{\mathrm{a}}\end{array}$ \\
\hline 19N/04E-25K01S & Robinett, Roger & 400 & -- & $06 / 12 / 95$ & -- & - & $\mathrm{H}$ & Supplies 1 home \\
\hline 19N/04E-25Q01S & Koehler, Carl & 450 & 50 & $06 / 12 / 95$ & 100 & 9.0 & $\mathbf{H}$ & Supplies 2 homes \\
\hline 19N/04E-30H01S & Marcum Spring & 340 & -- & $10 / 31 / 95$ & -- & - & $\mathrm{U}$ & Destroyed in mid-1980's. WSB-22 ${ }^{\mathrm{a}}$ \\
\hline 19N/04E-35Q01S & Weyerhaeuser Timber & 545 & -- & $10 / 31 / 95$ & -- & - & $\mathrm{U}$ & Destroyed. Filled, leveled, and developed \\
\hline 19N/04E-36R01S & Mueler & -- & -- & $10 / 11 / 95$ & -. & -- & -- & Could not locate, assumed destroyed \\
\hline 20N/03E-08J01S & Northern Pacific RR & 180 & -- & $10 / 30 / 95$ & -- & -- & -- & Destroyed. Possibly filled in by $\mathrm{I}-5$. WSB $-22^{\mathrm{a}}$ \\
\hline 20N/03E-09M01S & Unknown & 180 & $\begin{array}{r}24 \\
120\end{array}$ & $\begin{array}{l}10 / 07 / 95 \\
03 / 19 / 96\end{array}$ & $\begin{array}{l}276 \\
289\end{array}$ & $\begin{array}{l}11.0 \\
11.5\end{array}$ & -- & In ravine below Hood Street Reservoir \\
\hline 20N/03E-09N01S & Northern Pacific RR & 175 & -- & $10 / 11 / 95$ & -- & - & -- & Destroyed. Valley was filled. WSB-22 $2^{\mathrm{a}}$ \\
\hline 20N/03E-09P01S & Northern Pacific RR & 165 & - & $10 / 11 / 95$ & -- & -- & $\mathbf{U}$ & Destroyed. Canyon filled in 1970 's. WSB-22a \\
\hline 20N/03E-09Q01S & Northern Pacific RR & 225 & $\begin{array}{ll}139 & b \\
268 & b\end{array}$ & $\begin{array}{l}10 / 07 / 95 \\
03 / 18 / 96\end{array}$ & $\begin{array}{l}277 \\
433\end{array}$ & $\begin{array}{l}11.5 \\
11.2\end{array}$ & -- & $\begin{array}{l}\text { Spring flows from gravel above a till deposit } \\
\text { WSB-22 }\end{array}$ \\
\hline 20N/03E-14H01S & Cullen, Fred & 90 & $\begin{array}{l}48 \\
60\end{array}$ & $\begin{array}{l}10 / 30 / 95 \\
03 / 19 / 96\end{array}$ & $\begin{array}{l}215 \\
219\end{array}$ & $\begin{array}{l}10.2 \\
10.2\end{array}$ & $\mathrm{H}$ & Supplies 4 homes \\
\hline 20N/03E-23D01S & Northern Pacific RR & 225 & - & $10 / 30 / 95$ & $\sim$ & -- & - & Destroyed. Area filled and leveled. WSB $-22^{\mathrm{a}}$ \\
\hline 20N/03E-24B01S & Barker & 170 & $\begin{array}{c}10 \\
--\end{array}$ & $\begin{array}{l}10 / 12 / 95 \\
03 / 19 / 96\end{array}$ & $\begin{array}{l}232 \\
249\end{array}$ & $\begin{array}{l}15.0 \\
13.5\end{array}$ & $\mathbf{H}$ & $\begin{array}{l}\text { Supplies gas station and } 2 \text { homes. Flows from } \\
\text { recessional outwash deposits. Housing development } \\
\text { upgradient. WSB-22 } 2^{\mathrm{a}}\end{array}$ \\
\hline 20N/03E-24B03S & Unknown & 170 & -- & $10 / 11 / 95$ & -- & -- & $\mathrm{U}$ & $\begin{array}{l}\text { Housing development upgradient. Cliff face is } \\
\text { glacial outwash }\end{array}$ \\
\hline 20N/03E-24J01S & Hernall, HR & 160 & -- & $10 / 11 / 95$ & -- & -- & $\mathrm{U}$ & Destroyed. New construction on hillside \\
\hline 20N/03E-25A01S & Canyon Road Springs & 160 & $\begin{array}{l}208 \\
140^{c}\end{array}$ & $\begin{array}{l}10 / 12 / 95 \\
03 / 19 / 96\end{array}$ & $\begin{array}{l}302 \\
310\end{array}$ & $\begin{array}{l}12.0 \\
10.3\end{array}$ & $\sim$ & $\begin{array}{l}\text { Located at Miles Sand \& Gravel. Flows from } \\
\text { Vashon recessional outwash. WSB-22 }\end{array}$ \\
\hline
\end{tabular}


Table 6.--Records of springs inventoried for this study during 1995 and 1996 in the Tacoma-Puyallup area, Washington--Continued

\begin{tabular}{|c|c|c|c|c|c|c|c|c|}
\hline Spring number & Owner & $\begin{array}{l}\text { Altitude } \\
\text { (feet) }\end{array}$ & $\begin{array}{l}\text { Discharge } \\
\text { (gpm) }\end{array}$ & $\begin{array}{l}\text { Date } \\
\text { inven- } \\
\text { toried }\end{array}$ & $\begin{array}{l}\text { Specific } \\
\text { conductance } \\
(\mu \mathrm{S} / \mathrm{cm})\end{array}$ & $\begin{array}{l}\text { Temperature } \\
\text { (degrees C) }\end{array}$ & Use & Remarks \\
\hline 20N/04E-30L03S & Unknown & 230 & -- & $10 / 12 / 95$ & -- & - & $\mathrm{U}$ & Destroyed. Gravel pit occupies area. WSB- $22^{\mathrm{a}}$ \\
\hline 20N/04E-32J01S & Maplewood Springs & 50 & $3,040^{d}$ & $07 / 05 / 95$ & 190 & 9.5 & $P$ & $\begin{array}{l}\text { Estimated discharge is about } 5 \text { million gal/day. } \\
\text { Supplies approximately } 4 \text { million gal/day for } \\
\text { drinking water and } 1 \text { million gal/day to fish hatchery. } \\
\text { WSB-22 }\end{array}$ \\
\hline 20N/04E-34N02S & Cooper, Marie & 190 & -- & $06 / 01 / 95$ & -- & -- & $\mathrm{U}$ & \\
\hline 20N/04E-34Q01S & $\begin{array}{l}\text { City of Puyallup } \\
\text { Wildwood Park }\end{array}$ & 385 & $\begin{array}{l}42 \\
96\end{array}$ & $\begin{array}{l}10 / 30 / 95 \\
03 / 19 / 96\end{array}$ & $\begin{array}{l}162 \\
151\end{array}$ & $\begin{array}{l}10.0 \\
10.5\end{array}$ & $\mathrm{U}$ & $\begin{array}{l}\text { Located in Wildwood Park. Flows from recessional } \\
\text { outwash above Vashon till. WSB- } 22^{\mathrm{a}}\end{array}$ \\
\hline 20N/04E-36D03S & Unknown & 110 & $\begin{array}{r}4 \\
12\end{array}$ & $\begin{array}{l}10 / 23 / 95 \\
03 / 19 / 96\end{array}$ & $\begin{array}{l}212 \\
167\end{array}$ & $\begin{array}{r}12.0 \\
9.0\end{array}$ & -- & $\begin{array}{l}\text { Flows from sand \& gravel layer along Highway } 162 . \\
\text { WSB-22 }\end{array}$ \\
\hline $21 \mathrm{~N} / 02 \mathrm{E}-25 \mathrm{~B} 01 \mathrm{~S}$ & $\begin{array}{l}\text { City of Tacoma } \\
\text { (Public Utilities) }\end{array}$ & 120 & 1,194 & $03 / 18 / 96$ & 222 & 10.5 & -- & $\begin{array}{l}\text { Spring has multiple branches. Houses above stream } \\
\text { and sewer treatment plant down stream. WSB- } 22^{\mathrm{a}}\end{array}$ \\
\hline 21N/02E-34E01S & Northern Pacific RR & 20 & $\begin{array}{l}15 \\
19\end{array}$ & $\begin{array}{l}10 / 11 / 95 \\
03 / 18 / 96\end{array}$ & $\begin{array}{l}193 \\
232\end{array}$ & $\begin{array}{l}12.0 \\
10.0\end{array}$ & - & $\begin{array}{l}\text { Near Memorial Park. Flows from beneath Vashon } \\
\text { till in the Vashon advance and proglacial deposits }\end{array}$ \\
\hline $21 \mathrm{~N} / 02 \mathrm{E}-34 \mathrm{~F} 01 \mathrm{~S}$ & Unknown & 175 & $\begin{array}{l}40 \\
17\end{array}$ & $\begin{array}{l}10 / 11 / 95 \\
03 / 18 / 96\end{array}$ & $\begin{array}{l}156 \\
182\end{array}$ & $\begin{array}{r}11.0 \\
9.5\end{array}$ & $-\cdot$ & $\begin{array}{l}\text { Near Memorial Park. Flows from beneath Vashon } \\
\text { till in the Vashon advance and proglacial deposits. } \\
\text { Landslide in winter } 95 \text { has changed spring and spring } \\
\text { discharge. WSB-22 }\end{array}$ \\
\hline $21 \mathrm{~N} / 02 \mathrm{E}-34 \mathrm{~F} 02 \mathrm{~S}$ & Unknown & 175 & $\begin{array}{l}217 \\
240\end{array}$ & $\begin{array}{l}10 / 11 / 95 \\
03 / 18 / 96\end{array}$ & $\begin{array}{l}208 \\
212\end{array}$ & $\begin{array}{l}11.0 \\
11: 0\end{array}$ & -- & $\begin{array}{l}\text { Near Memorial Park. Flows out base of recessional } \\
\text { outwash over top of till. WSB }-22^{\mathrm{a}}\end{array}$ \\
\hline $21 \mathrm{~N} / 02 \mathrm{E}-34 \mathrm{~F} 03 \mathrm{~S}$ & Unknown & 175 & $\begin{array}{l}280 \\
100\end{array}$ & $\begin{array}{l}10 / 11 / 95 \\
03 / 18 / 96\end{array}$ & $\begin{array}{l}214 \\
156\end{array}$ & $\begin{array}{l}11.0 \\
11.0\end{array}$ & -- & $\begin{array}{l}\text { Near Memorial Park. Flows out base of recessional } \\
\text { outwash over top of till. WSB- } 22^{\mathrm{a}}\end{array}$ \\
\hline $21 \mathrm{~N} / 03 \mathrm{E}-30 \mathrm{M} 01 \mathrm{~S}$ & $\begin{array}{l}\text { Metropolitan } \\
\text { Park District of Tacoma }\end{array}$ & 45 & $\begin{array}{l}120 \\
240\end{array}$ & $\begin{array}{l}10 / 31 / 95 \\
03 / 18 / 96\end{array}$ & $\begin{array}{l}250 \\
248\end{array}$ & $\begin{array}{l}10.5 \\
11.0\end{array}$ & $\begin{array}{l}-- \\
--\end{array}$ & $\begin{array}{l}\text { Spring located in Puget Gardens Park. Confined by } \\
\text { clay with gravel on top. Puyallup Tribal Fisheries } \\
\text { Report provides some information. WSB- } 22^{\mathrm{a}}\end{array}$ \\
\hline $21 \mathrm{~N} / 03 \mathrm{E}-30 \mathrm{M} 02 \mathrm{~S}$ & $\begin{array}{l}\text { Metropolitan } \\
\text { Park District of Tacoma }\end{array}$ & 30 & $\begin{array}{ll}152 & b \\
723 & b\end{array}$ & $\begin{array}{l}10 / 31 / 95 \\
03 / 18 / 96\end{array}$ & $\begin{array}{l}395 \\
255\end{array}$ & $\begin{array}{l}11.2 \\
11.3\end{array}$ & $\begin{array}{l}-- \\
--\end{array}$ & $\begin{array}{l}\text { Springs located in Puget Gardens Park. Confined by } \\
\text { clay with gravel on top. Puyallup Tribal Fisheries } \\
\text { Report provides information }\end{array}$ \\
\hline
\end{tabular}

a Springs were previously inventoried. Information available in Water Supply Bulletin No. 22, Walters and Kimmel (1968).

b The specific conductance and temperature are averaged measurements of the spring--at several locations along the cliff face.
c Landslide diverted part of the spring discharge from the main spring discharge point--part of the diverted spring discharge in new spring location--not able to get all of spring discharge. The specific conductance and temperature are the average of two measurements taken from the old and new spring location.

d Discharge is average for the year; $a$ fraction of spring discharge is withdrawn for public supply. 
Table 7.--Summary of estimated water use during 1996 by water-use category, source, and hydrogeologic unit in the Tacoma-Puyallup area, Washington

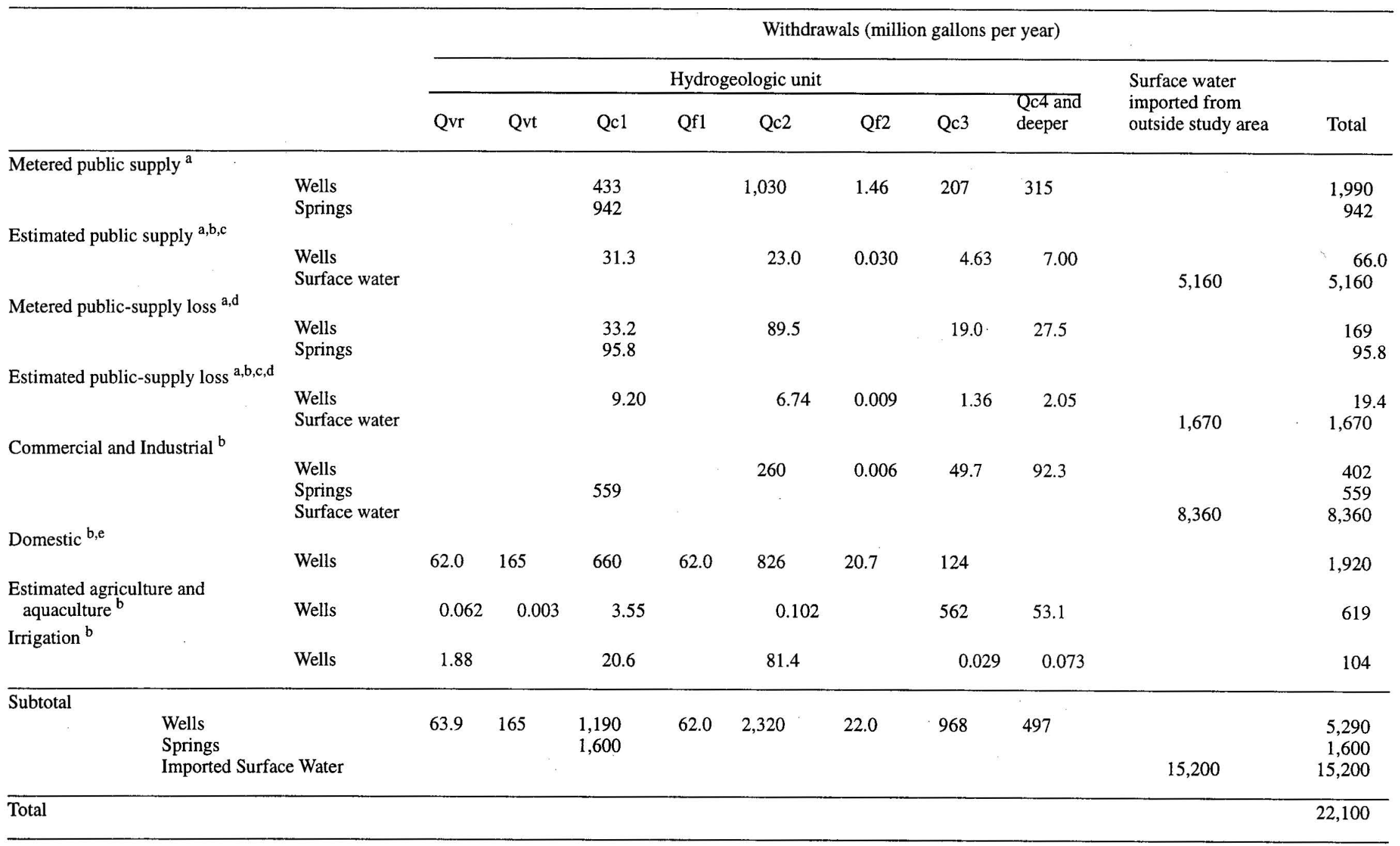

\footnotetext{
a Includes Class A and Class B water systems.

b Amount of water withdrawn is based on suppliers' estimate or area population and represents a minimum value.

c Distribution of water withdrawn from specific units based on distribution of water withdrawn from metered public supply and from well logs of wells which supply the area.

d Loss includes water loss in leakage in suppliers' distribution system and water used for public uses such as fire hydrants, public parks, street cleaning, etc.

e Distribution of water used for specific hydrogeologic units based on domestic wells that were inventoried during the study.
} 
Qc1, supplying 20 percent (20.6 million gallons). Irrigators contacted included golf courses, berry farms, tree farms, nurseries, pastures, daffodil farms, and vegetable farms. Water used for residential purposes such as lawn watering is accounted for under the public-supply category.

\section{Ground-Water Budget}

The ground-water budget for the study area was calculated from the information reported in the previous sections. Although it is an estimate based on incomplete data, the ground-water budget gives some insight into the present dynamics of the ground-water system and may indicate where more information is needed to improve the budget estimate.

Water flows into the study area's ground water from recharge from the surface and from ground water moving in across the south and southwest boundary. Recharge to the study area's ground-water system comes from precipitation, septic tank leachate, public water-supply losses, river, creek, and lake infiltration, and irrigation. Discharge from the ground-water system moves to the creeks, the Puyallup River, Puget Sound, springs, seepage faces, ground-water outflow, and is pumped from wells. The components of the ground-water budget equation can be expressed as

$$
\begin{aligned}
& G W_{i n}+R_{p t}+R_{i r r}+R_{i m p}+R_{i n f}= \\
& D_{c r}+D_{s p r}+D_{p}+D_{r i v}+D_{p s}+G W_{o u t}+\Delta S
\end{aligned}
$$

$$
\begin{aligned}
\text { where } & \\
G W_{i n} & =\text { ground-water movement into the study area; } \\
R_{p t} & =\text { recharge from precipitation and septic systems; } \\
R_{i r r} & =\text { recharge from irrigation; } \\
R_{i m p} & =\text { recharge from public water-supply systems; } \\
R_{i n f} & =\text { recharge from river, creek and lake infiltration; } \\
D_{c r} & =\text { discharge to creeks; } \\
D_{s p r} & =\text { discharge to the springs and seepage faces; } \\
D_{p} & =\text { discharge from pumping wells; } \\
D_{r i v} & =\text { discharge to the Puyallup River; } \\
D_{p s} & =\text { discharge to Puget Sound; } \\
G W_{\text {out }} & =\text { ground-water movement out of the study area; } \\
\Delta S & =\text { and }
\end{aligned}
$$

In the shallower ground-water system, hydrogeologic units Qc1 and above, ground-water movement across the south and southwest boundary is in both directions, inflow to the north and outflow to the southwest through the Clover Creek Channel and potentially through the Kirby and South Tacoma Channels. The ground-water inflow and outflow across the south and southwest boundary of the study area were not quantified due to the complex configuration of the study-area boundary and a lack of available data. Ground-water inflow to the deeper ground-water system was also not quantified due to a lack of data.

Ground-water recharge was estimated at $92 \mathrm{ft}^{3} / \mathrm{s}$, which is about 37 percent of the annual precipitation over the study area. This value includes the estimates from precipitation, irrigation, and imported water (see section on Ground-Water Recharge), but estimates for ground-water infiltration from lakes, creeks, and the Puyallup River were not available.

The total of the components of ground-water discharge from the study area that could be estimated was $96 \mathrm{ft}^{3} / \mathrm{s}$. This value is the sum of estimated baseflow from the creeks of $59 \mathrm{ft}^{3} / \mathrm{s}$, and the estimated discharge from pumping wells of $22 \mathrm{ft}^{3} / \mathrm{s}$, plus the average of the total spring and fall discharge values, $7 \mathrm{ft}^{3} / \mathrm{s}$, added to the average annual discharge for Maplewood Spring, $7 \mathrm{ft}^{3} / \mathrm{s}$. Discharge estimates for the remaining components, $D_{\text {riv }}$ and $D_{p s}$, and for the rate of change of ground-water storage, $\Delta S$, were not quantified. Assuming the ground-water system is in equilibrium and there is no change in storage and substituting the values back into the equation, the ground-water budget is

$$
\begin{aligned}
& G W_{\text {in }}+92+R_{\text {inf }}= \\
& 59+14+23+D_{\text {riv }}+D_{p s}+G W_{\text {out }}+\Delta S
\end{aligned}
$$

Of the unquantified inflow and outflow components in the equation, ground-water inflow $\left(G W_{\text {in }}\right)$ and groundwater outflow $\left(G W_{o u t}\right)$ are probably the most significant. Data collected to estimate these components would be valuable in obtaining a better estimate of the total ground-water budget. 
Based on the configuration of the study area and its general location in the regional ground-water system, the recharge to the ground-water system within the study area moves through the shallow ground-water system along relatively short flowpaths before being discharged to cliff faces as seeps and springs or to creeks. Assuming minimal ground-water inflow occurs from outside the study area to these upper units, a local ground-water budget was approximated for the shallow ground-water system, units Qc1 and above. The budget for the shallow ground-water system differs from the overall budget by (1) including a term for discharge to deeper units and (2) including only the pumpage from the shallow system $\left(6 \mathrm{ft}^{3} / \mathrm{s}\right)$. This local water budget, expressed in equation 8 , shows that at least 86 percent of the quantified recharge within the study area discharges through the shallow ground-water system. The remaining 14 percent or less is discharged to unmeasured springs, seeps, stormwater discharge, or recharge to the deeper ground-water system. Thus, units in the shallow ground-water system constitute a local ground-water movement system, and the hydrogeologic units below Qc1 are part of a more regional ground-water system. Since most of the public-supply wells are completed in the deeper units (table 7), information on the regional ground-water movement system is necessary to determine the ground-water budget for the deeper units. This would include more information and data collected on the ground-water inflow and outflow and discharge to the Puyallup River and Puget Sound.

$$
\begin{aligned}
& G W_{i n}+92+R_{\text {inf }}= \\
& 59+D_{\text {riv }}+14+6+D_{p s}+G W_{\text {out }}+D_{g w}
\end{aligned}
$$

where

$D_{g w}=$ flow to the deeper units.

\section{GROUND-WATER QUALITY}

Water from 33 of the wells and springs (fig. 18) was sampled and analyzed to determine the quality of ground water in the study area. All 33 samples were analyzed for nitrite plus nitrate, major ions, arsenic, iron, manganese, and bacteria. A subset of samples was analyzed for trace elements, MBAS, boron, radon, pesticides, TOC, and VOCs (table 8). Temperature, $\mathrm{pH}$, specific conductance, alkalinity, and dissolved-oxygen content were also determined for all 33 samples.
The overall quality of ground water in the study area is good; only four constituents were found at concentrations above maximum levels specified in drinking water standards or guidelines. Two of the four constituents, the pesticide dieldrin in water from one well and total coliform bacteria in water from four wells and springs, did not meet standards or guidelines related to human health (table 9). Concentrations of iron or manganese in water from eight wells and springs were above maximum concentrations specified by secondary drinking water standards, which are not health related. The occurrence of iron and manganese in ground water at concentrations not meeting secondary drinking water standards is fairly typical in the Puget Sound Region (Turney, 1986). Concentrations of other trace elements met drinking water standards or guidelines.

Dissolved solids in water are made up mostly of the dissolved ions calcium, sodium, potassium, bicarbonate, sulfate, and chloride. In some instances, other substances, like silica, or other ions, like nitrate, make up a significant part of the dissolved-solids content. Large concentrations of dissolved solids reduce the desirability of the water for drinking, but this is not a problem in the study area, where the maximum observed concentration was $261 \mathrm{mg} / \mathrm{L}$, which is well below the secondary drinking water standard of $500 \mathrm{mg} / \mathrm{L}$ (table 9).

Ground water in the study area is predominately of the bicarbonate type, but percentages of sodium plus potassium vary with location and depth (fig. 19). Higher percentages of sodium plus potassium in shallow ground water probably indicate effects of land-use activities. Higher percentages in deep ground water are generally indicative of natural sources. Because ions compose a large part of the dissolved-solids content in water, specific conductance (a measure of electrical conductivity) is also shown in figure 19 as a good indicator of dissolved-solids concentrations.

Radon activities in ground-water samples ranged from $260 \pm 25$ to $810 \pm 28 \mathrm{pCi} / \mathrm{L}$ (picocuries per liter); the median activity was $450 \pm 28 \mathrm{pCi} / \mathrm{L}$ (table 9 ). The source of radon in ground water is the radioactive decay of uranium, and higher radon levels are found in areas underlain by granites or similar rocks that usually contain more uranium. Compared with other parts of the United States, the geologic radon potential of the Puget Sound Region is low (Schumann, 1993), and radon activities in ground water in the study area are indicative of that low potential. 


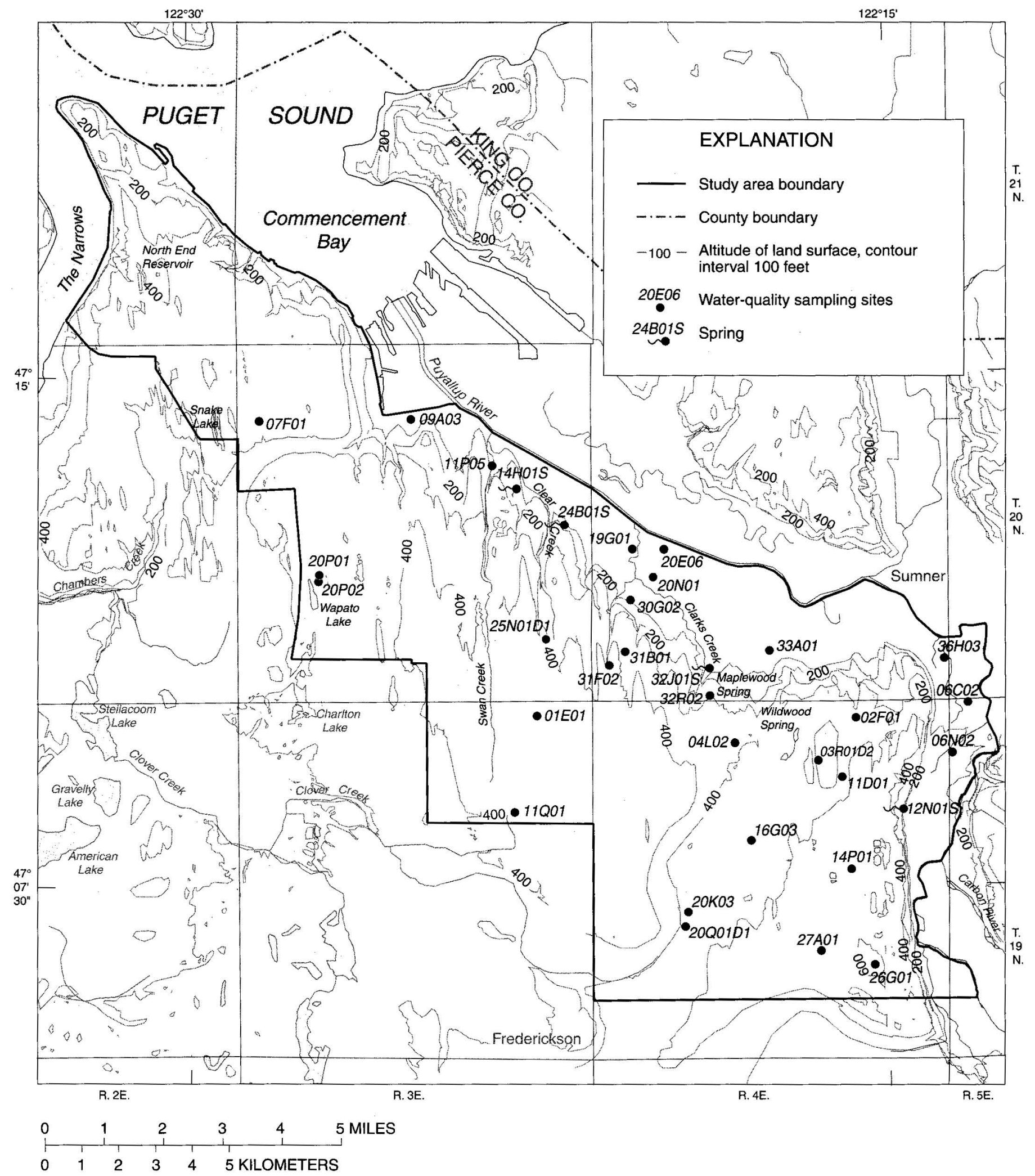

Figure 18. Locations of wells and springs sampled for water quality in 1996 in the Tacoma-Puyallup area, Washington. 
Table 8.--Matrix indicating analyses performed on sample from well or spring and hydrogeologic unit tapped by well or spring in the Tacoma-Puyallup area, Washington

[Hydrogeologic unit: Qvr, surficial aquifer; Qvt, upper semiconfining unit; Qcl, upper confined aquifer; Qfl, semiconfining unit below Qcl; Qc2, second confined aquifer; Qc3, third confined aquifer; Qc4, fourth confined aquifer; $x$, analysis performed; --, analysis not performed]

\begin{tabular}{|c|c|c|c|c|c|c|c|c|c|c|c|}
\hline $\begin{array}{l}\text { Local well } \\
\text { number }\end{array}$ & $\begin{array}{l}\text { Well located } \\
\text { in valley }(v) \\
\text { or upland }(\mathrm{u})\end{array}$ & $\begin{array}{l}\text { Depth to } \\
\text { top of first } \\
\text { opening }\end{array}$ & $\begin{array}{l}\text { Hydrogeo- } \\
\text { logic unit }\end{array}$ & $\begin{array}{l}\text { Nitrate, major } \\
\text { ions, and field mea- } \\
\text { surements (alkalinity, } \\
\text { dissolved oxygen, } \\
\text { temperature, pH, and } \\
\text { specific conductance) }\end{array}$ & $\begin{array}{l}\text { Boron } \\
\text { and MBAS } \\
\text { (methylene } \\
\text { blue active } \\
\text { substances) }\end{array}$ & Arsenic & $\begin{array}{l}\text { Other } \\
\text { trace } \\
\text { elements }\end{array}$ & $\begin{array}{l}\text { Volatile } \\
\text { organic } \\
\text { compounds }\end{array}$ & Pesticides & Radon & $\begin{array}{l}\text { Total } \\
\text { organic } \\
\text { carbon }\end{array}$ \\
\hline $19 \mathrm{~N} / 05 \mathrm{E}-06 \mathrm{C} 02$ & $\mathrm{v}$ & 212.75 & $\mathrm{Qc2}^{\mathrm{a}}$ & $\mathrm{x}$ & $\mathrm{x}$ & $\mathrm{x}$ & -. & -- & -- & $\mathrm{x}$ & $\mathrm{x}$ \\
\hline $19 \mathrm{~N} / 05 \mathrm{E}-06 \mathrm{~N} 02$ & $\mathrm{v}$ & 99 & Qc2 & $\mathrm{x}$ & $\mathrm{x}$ & $\mathrm{x}$ & -- & -- & -- & -- & -- \\
\hline 20N/03E-09A03 & $\mathrm{v}$ & 199 & Qc3 & $\mathrm{x}$ & -. & $\mathrm{x}$ & -- & -- & -- & $\mathrm{x}$ & $\mathrm{x}$ \\
\hline 20N/03E-11P05 & $\mathrm{v}$ & 25 & Qc1 & $\mathrm{x}$ & $\mathrm{x}$ & $\mathrm{x}$ & $\mathrm{x}$ & $\mathrm{x}$ & $\mathrm{x}$ & -. & -- \\
\hline 20N/04E-19G01 & $\mathrm{v}$ & 53 & Qc1 & $\mathrm{x}$ & $\mathrm{x}$ & $\mathrm{x}$ & $\mathrm{x}$ & $\mathrm{x}$ & $\mathrm{x}$ & -- & -. \\
\hline 20N/04E-20E06 & $\mathrm{v}$ & 105 & Qc2 & $\mathrm{x}$ & $\mathrm{x}$ & $\mathrm{x}$ & -- & $\mathrm{x}$ & -- & -. & - \\
\hline 20N/04E-20N01 & $\mathrm{v}$ & 90 & $\mathrm{Qc}^{\mathrm{a}}$ & $\mathrm{x}$ & $\mathrm{x}$ & $\mathrm{x}$ & -- & -- & -- & -. & -- \\
\hline $20 \mathrm{~N} / 04 \mathrm{E}-33 \mathrm{~A} 01$ & $\mathrm{v}$ & 321 & $\mathrm{Qc}^{\mathrm{a}}$ & $\mathrm{x}$ & $\mathrm{x}$ & $\mathrm{x}$ & -- & - & -- & -- & -- \\
\hline $20 \mathrm{~N} / 04 \mathrm{E}-36 \mathrm{H} 03$ & $\mathrm{v}$ & 86.5 & Qc2 & $\mathrm{x}$ & $\mathrm{x}$ & $\mathrm{x}$ & $\mathrm{x}$ & $\mathrm{x}$ & $\mathrm{x}$ & -. & $\mathrm{x}$ \\
\hline 19N/03E-01E01 & $\mathbf{u}$ & 256 & Qc2 & $\mathrm{x}$ & -- & $\mathrm{x}$ & -. & -- & -- & $\mathrm{x}$ & $\mathrm{x}$ \\
\hline 19N/03E-11Q01 & $\mathbf{u}$ & 237 & Qc2 & $\mathrm{x}$ & -- & $\mathrm{x}$ & - & -- & -. & $x$ & $\mathrm{x}$ \\
\hline 19N/04E-02F01 & $\mathrm{u}$ & 550 & Qc3 & $\mathrm{x}$ & -- & $\mathrm{x}$ & -- & -- & -- & $\mathrm{x}$ & $\mathrm{x}$ \\
\hline 19N/04E-03R01D2 & $\mathrm{u}$ & 552 & $\mathrm{Qc}^{\mathrm{a}}$ & $\mathrm{x}$ & $\mathrm{x}$ & $\mathrm{x}$ & $\mathrm{x}$ & -- & -. & $\mathrm{x}$ & $\mathrm{x}$ \\
\hline 19N/04E-04L02 & u & 254 & Qc2 & $\mathrm{x}$ & -. & $\mathrm{x}$ & -- & -- & -- & -- & -- \\
\hline 19N/04E-11D01 & $\mathrm{u}$ & 119.5 & QcI & $\mathrm{x}$ & $\mathrm{x}$ & $\mathrm{x}$ & -- & -- & $\mathrm{x}$ & -- & -- \\
\hline 19N/04E-12N01S & u & spring & Qvr & $\mathrm{x}$ & $\mathrm{x}$ & $\mathrm{x}$ & $\mathrm{x}$ & $\mathrm{x}$ & $\mathrm{x}$ & -- & -- \\
\hline 19N/04E-14P01 & $\mathrm{u}$ & 22 & Qvr/Qvt & $\mathrm{x}$ & $\mathrm{x}$ & $\mathrm{x}$ & $\mathrm{x}$ & $\mathrm{x}$ & $\mathrm{x}$ & -- & -. \\
\hline 19N/04E-16G03 & u & 375 & Qc2 & $\mathrm{x}$ & -- & $\mathrm{x}$ & -- & -- & -- & $\mathrm{x}$ & $\mathrm{x}$ \\
\hline 19N/04E-20K03 & u & 193 & Qc1 & $\mathrm{x}$ & $\mathrm{x}$ & $\mathrm{x}$ & .. & -- & -- & -- & -- \\
\hline 19N/04E-20Q01D1 & $\mathrm{u}$ & 315 & $\mathrm{Qc}^{\mathrm{a}}$ & $\mathrm{x}$ & $\mathrm{x}$ & $\mathrm{x}$ & -- & -- & -- & -. & -- \\
\hline 19N/04E-26G01 & u & 369 & Qc2 & $\mathrm{x}$ & -- & $\mathrm{x}$ & -- & -- & -. & $\mathrm{x}$ & $\mathrm{x}$ \\
\hline $19 \mathrm{~N} / 04 \mathrm{E}-27 \mathrm{~A} 01$ & u & 206 & Qc1 & $\mathrm{x}$ & -- & $\mathrm{x}$ & -- & - & -- & -- & -- \\
\hline 20N/03E-07F01 & u & 87 & Qc1 & $\mathrm{x}$ & $\mathrm{x}$ & $\mathrm{x}$ & $\mathrm{x}$ & $\mathrm{x}$ & $\mathrm{x}$ & -- & -- \\
\hline $20 \mathrm{~N} / 03 \mathrm{E}-14 \mathrm{H} 01 \mathrm{~S}$ & u & spring & Qc1 & $\mathrm{x}$ & $\mathrm{x}$ & $\mathrm{x}$ & $\mathrm{x}$ & $\mathrm{x}$ & $\mathrm{x}$ & -- & -- \\
\hline 20N/03E-20P01 & $\mathbf{u}$ & 103 & Qc1 & $\mathrm{x}$ & $\mathrm{x}$ & $\mathrm{x}$ & $\mathrm{x}$ & $\mathrm{x}$ & $\mathrm{x}$ & $\mathrm{x}$ & $\mathrm{x}$ \\
\hline 20N/03E-20P02 & $\mathbf{u}$ & 239 & Qc2 some Qf & Qf1 & -. & $\mathrm{x}$ & -- & -- & - & $\mathrm{x}$ & $x$ \\
\hline 20N/03E-24B01S & u & spring & Qc1 & $\mathrm{x}$ & $\mathrm{x}$ & $\mathrm{x}$ & $\mathrm{x}$ & $\mathrm{x}$ & $\mathrm{x}$ & -- & -. \\
\hline 20N/03E-25N01D1 & $\mathbf{u}$ & 258 & Qc2 & $\mathrm{x}$ & -- & $\mathrm{x}$ & -- & -- & - & -- & -- \\
\hline 20N/04E-30G02 & $\mathrm{u}$ & 78.5 & Qc1 & $\mathrm{x}$ & $\mathrm{x}$ & $\mathrm{x}$ & $\mathrm{x}$ & $\mathrm{x}$ & $\mathrm{x}$ & -- & -- \\
\hline 20N/04E-31B01 & $\mathbf{u}$ & $56^{\mathrm{b}}$ & Qvt & $\mathrm{x}$ & $\mathrm{x}$ & $\mathrm{x}$ & -- & $\ldots$ & - & -- & -- \\
\hline 20N/04E-31F02 & $\mathbf{u}$ & 180 & $\begin{array}{l}\text { lens of } \\
\text { gravel in Qf1 }\end{array}$ & $\mathrm{f} 1$ & $\mathrm{x}$ & $\mathrm{x}$ & -- & -- & -- & -- & - \\
\hline $20 \mathrm{~N} / 04 \mathrm{E}-32 \mathrm{~J} 01 \mathrm{~S}$ & $\mathbf{u}$ & spring & Qc1 & $\mathrm{x}$ & $\mathrm{x}$ & $\mathrm{x}$ & $\mathrm{x}$ & $\mathrm{x}$ & $\mathrm{x}$ & $\mathrm{x}$ & $\mathrm{x}$ \\
\hline 20N/04E-32R02 & $\mathbf{u}$ & 271 & Qc2 & $\mathrm{x}$ & $-\cdot$ & $\mathrm{x}$ & -- & - & -. & -- & -- \\
\hline
\end{tabular}

${ }^{\text {a }}$ Hydrogeologic unit of well is questionable.

b Approximate depth to first opening. 
Table 9.--Summary of concentrations of inorganic constituents, trace elements, and bacteria, values of other properties, concentrations of pesticides and volatile organic compounds detected, and associated drinking water standards or guidelines, in the Tacoma-Puyallup area, Washington

[Concentrations of constituents, standards, and guidelines are in milligrams per liter unless otherwise noted; <, less than; cols./100 mL, colonies per $100 \mathrm{milliliters;}$ $\mathrm{mg} / \mathrm{L}$, milligrams per liter; $\mu \mathrm{g} / \mathrm{L}$, micrograms per liter; $\mathrm{pCi} / \mathrm{L}$, picocuries per liter; $\mu \mathrm{S} / \mathrm{cm}$, microsiemens per centimeter at $25^{\circ}$ Celsius; $\mathrm{E}$, estimated value; $\mathrm{MCL}$, maximum contaminant level (USEPA, 1996); SMCL, secondary maximum contaminant level (USEPA, 1991); RSD, USEPA risk-specific dose health advisory associated with a cancer risk of one in a million (Nowell and Resek, 1994); HA, USEPA lifetime health advisory for a 70-kilogram adult (USEPA, 1996); AL, USEPA action level, which requires treatment if concentrations exceed action level (USEPA, 1995); na, not applicable]

\begin{tabular}{|c|c|c|c|c|c|c|c|}
\hline \multirow[b]{2}{*}{ Constituent or property } & \multirow{2}{*}{$\begin{array}{l}\text { Number of } \\
\text { samples }\end{array}$} & \multicolumn{3}{|c|}{ Concentration or value } & \multirow{2}{*}{$\begin{array}{l}\text { Standard or } \\
\text { guideline }\end{array}$} & \multirow{2}{*}{$\begin{array}{l}\text { Number of samples } \\
\text { exceeding standard } \\
\text { or guideline }\end{array}$} & \multirow{2}{*}{$\begin{array}{l}\text { Type of } \\
\text { standard or } \\
\text { guideline }\end{array}$} \\
\hline & & Minimum & Median & Maximum & & & \\
\hline
\end{tabular}

Alkalinity $\left(\mathrm{mg} / \mathrm{L}\right.$ as $\left.\mathrm{CaCO}_{3}\right)$

Calcium

Chloride

Fluoride

Magnesium

Nitrite plus nitrate (as nitrogen)

Potassium

Sodium

Sulfate

Major Inorganic Constituents

33

22
7.4
1.6
$<0.1$
2.4
$<0.05$
0.5
4.4
0.3

75
16
5.4
$<0.1$
7.7
1.1
2
7
5.2

210
39
10
0.5
21
6.4
6.8
20
23

none
none
250
4
none
10
none
none
500

na
na
0
0
na
0
na
na
0

none

Arsenic $(\mu \mathrm{g} / \mathrm{L})$

Barium $(\mu \mathrm{g} / \mathrm{L})$

Boron $(\mu \mathrm{g} / \mathrm{L})$

Cadmium $(\mu \mathrm{g} / \mathrm{L})$

Chromium $(\mu \mathrm{g} / \mathrm{L})$

Copper $(\mu \mathrm{g} / \mathrm{L})$ (at tap)

Iron $(\mu \mathrm{g} / \mathrm{L})$

Lead $(\mu \mathrm{g} / \mathrm{L})$ (at tap)

Manganese $(\mu \mathrm{g} / \mathrm{L})$

Mercury $(\mu \mathrm{g} / \mathrm{L}$ )

Selenium $(\mu \mathrm{g} / \mathrm{L})$

Silver $(\mu \mathrm{g} / \mathrm{L})$

Zinc $(\mu \mathrm{g} / \mathrm{L})$

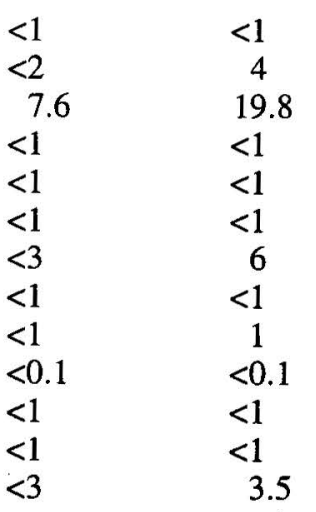

Trace Elements

$\begin{array}{ccc}<1 & 10 & 50 \\ 4 & 24 & 2,000 \\ 19.8 & 68.2 & 600 \\ <1 & <1 & 5 \\ <1 & <1 & 100 \\ <1 & 3 & 1,300 \\ 6 & 12,000 & 300 \\ <1 & <1 & 15 \\ 1 & 1,100 & 50 \\ <0.1 & 0.1 & 2 \\ <1 & <1 & 50 \\ <1 & <1 & 100 \\ 3.5 & 88 & 5,000\end{array}$

none

SMCL

MCL

none

$\mathrm{MCL}$

none

none

MCL

MCL

MCL

$\mathrm{HA}$

MCL

MCL

AL

SMCL

$\mathrm{AL}$

SMCL

MCL

MCL

SMCL

SMCL 
Table 9.--Summary of concentrations of inorganic constituents, trace elements, and bacteria, values of other properties, concentrations of pesticides and volatile organic compounds detected, and associated drinking water standards or guidelines, in the Tacoma-Puyallup area, Washington--Continued

\begin{tabular}{|c|c|c|c|c|c|c|c|}
\hline \multirow[b]{2}{*}{ Constituent or property } & \multirow{2}{*}{$\begin{array}{l}\text { Number of } \\
\text { samples }\end{array}$} & \multicolumn{3}{|c|}{ Concentration or value } & \multirow{2}{*}{$\begin{array}{l}\text { Standard or } \\
\text { guideline }\end{array}$} & \multirow{2}{*}{$\begin{array}{l}\text { Number of samples } \\
\text { exceeding standard } \\
\text { or guideline }\end{array}$} & \multirow{2}{*}{$\begin{array}{l}\text { Type of } \\
\text { standard or } \\
\text { guideline }\end{array}$} \\
\hline & & Minimum & Median & Maximum & & & \\
\hline \multicolumn{8}{|c|}{ Bacteria } \\
\hline Coliform, Total (cols./100 mL) & 33 & $<1$ & $<1$ & 90 & $*$ & 4 & MCL \\
\hline Escherichia coli (cols./100 mL) & 7 & $<1$ & 2 & 43 & none & na & none \\
\hline Streptococci, Fecal (cols./100 mL) & 33 & $<1$ & $<1$ & 3 & none & na & none \\
\hline \multicolumn{8}{|c|}{ Other Properties and Constituents } \\
\hline Dissolved oxygen & 33 & $<0.1$ & 3.9 & 10.7 & none & na & none \\
\hline Dissolved solids & 33 & 61 & 132 & 261 & 500 & 0 & SMCL \\
\hline MBAS detergents & 22 & $<0.02$ & $<0.02$ & 0.02 & none & na & none \\
\hline $\mathrm{pH}$ (standard units) & 33 & 6.1 & 7 & 8 & $6.5-8.5$ & 0 & SMCL \\
\hline Radon $(\mathrm{pCi} / \mathrm{L})$ & 11 & 260 & 450 & 810 & none & na & none \\
\hline Silica & 33 & 16 & 35 & 62 & none & na & none \\
\hline Specific conductance $(\mu \mathrm{S} / \mathrm{cm})$ & 33 & 90 & 184 & 376 & none & na & none \\
\hline Total organic carbon & 12 & 0.1 & 0.35 & 2.8 & none & na & none \\
\hline \multicolumn{8}{|c|}{ Pesticides and Volatile Organic Compounds } \\
\hline Atrazine $(\mu \mathrm{g} / \mathrm{L})$ & 12 & $<0.001$ & $<0.001$ & $0.009 \mathrm{E}$ & 3 & 0 & MCL \\
\hline Desethylatrazine $(\mu \mathrm{g} / \mathrm{L})$ & 12 & $<0.002$ & $<0.002$ & $0.009 \mathrm{E}$ & none & na & none \\
\hline Dieldrin $(\mu \mathrm{g} / \mathrm{L})$ & 12 & $<0.001$ & $<0.001$ & 0.045 & 0.002 & 1 & RSD \\
\hline Diuron $(\mu \mathrm{g} / \mathrm{L})$ & 12 & $<0.02$ & $<0.02$ & 0.04 & 10 & 0 & $\mathrm{HA}$ \\
\hline Metribuzin $(\mu \mathrm{g} / \mathrm{L})$ & 12 & $<0.004$ & $<0.004$ & 0.024 & 100 & 0 & $\mathrm{HA}$ \\
\hline Pebulate $(\mu \mathrm{g} / \mathrm{L})$ & 12 & $<0.004$ & $<0.004$ & 0.075 & none & na & none \\
\hline Tebuthiuron $(\mu \mathrm{g} / \mathrm{L})$ & 12 & $<0.01$ & $<0.01$ & 0.078 & 500 & 0 & $\mathrm{HA}$ \\
\hline $1,1,1$-Trichloroethane $(\mu \mathrm{g} / \mathrm{L})$ & 12 & $<0.2$ & $<0.2$ & 0.17 & 200 & 0 & $\mathrm{MCL}$ \\
\hline
\end{tabular}

* MCL is based on presence/absence of total coliforms in a sample. If sample is total coliform positive, the culture must be analyzed to determine if fecal coliforms or Escherichia coli are present. If fecal coliform or Escherichia coli are detected, violation of MCL for total coliform has occurred (U.S. Environmental Protection Agency, 1996, Maximum contaminant levels (subpart G of 141 section 141.63 for microbiological contaminants, National primary drinking water regulations): U.S. Code of Federal Regulations Title 40, chap. I. There were a total of seven samples having total coliform colonies, four of which tested positive
for Escherichia coli. 

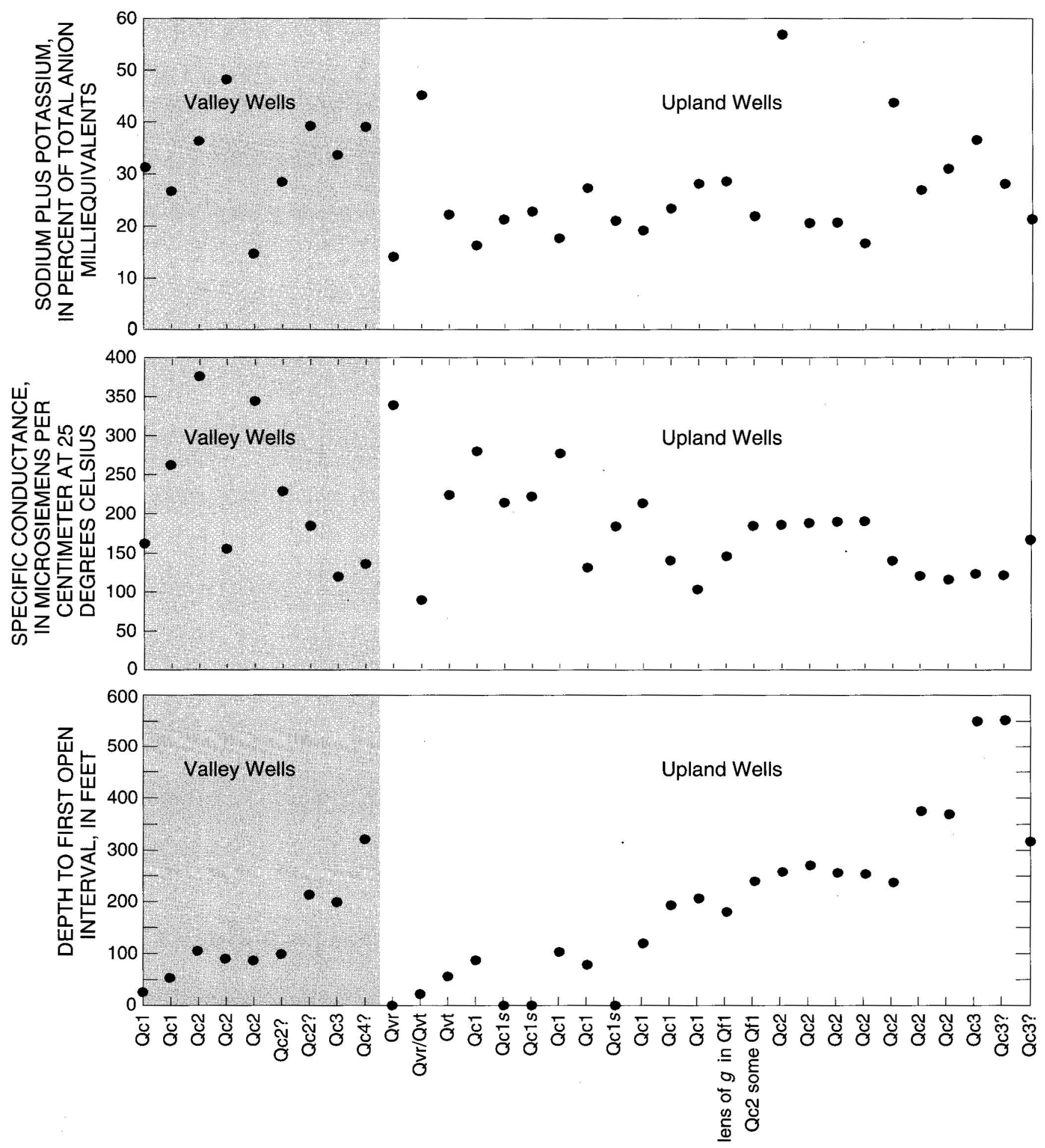

Water samples from wells completed in defined hydrogeologic units

Qvr Shallow aquifer; s designates spring

Qvt Upper semiconfined unit

Qc1 Upper confined aquifer; $s$ designates spring

Qf1 Semiconfined unit below Qc1; $g$ designates gravel

Qc2 Second confined aquifer

Qc3 Third confined aquifer

Qc4 Fourth confined aquifer

Figure 19. Relation between hydrogeologic unit and depth to first opening, specific conductance, and percent sodium plus potassium in the Tacoma-Puyallup area, Washington. 
In comparison, radon activities in ground waters collected by the USGS National Water Quality Assessment Program in 20 study units located throughout the United States ranged from 7 to $40,000 \mathrm{pCi} / \mathrm{L}$; the median was $508 \mathrm{pCi} / \mathrm{L}$ (Sarah Ryker, U.S. Geological Survey, written commun., 1997). In 1991, EPA proposed a maximum contaminant level of $300 \mathrm{pCi} / \mathrm{L}$ for radon in drinking water, but this rule has not been put into effect (U.S. Environmental Protection Agency, 1996).

Even though the overall quality of ground water is good, land-use activities have affected quality. These effects, as well as other factors influencing water quality, are discussed in the following sections.

\section{Conceptual Model of Factors Affecting Water Quality}

Variations in the quality of ground water in the study area relate to the complex interaction between land-use activities and natural factors. An analysis of the vulnerability of ground water in the Puget Sound Basin to contamination by nitrate (Tesoriero and Voss, 1997) illustrates this interaction. The authors found that ground water most vulnerable to nitrate contamination is shallow, in coarsegrained glacial sediments, and underlies areas with high percentages of agricultural or urban land uses. Deep ground water underlying fine-grained sediments is more isolated from the effects of land-use activities than shallow ground water underlying coarse-grained sediments.

The decrease in specific conductance values with depth (fig. 19) is another indication that deep ground water is more isolated from the effects of land-use activities. Valley and upland wells are grouped in figure 19 because, as will be discussed later, different factors affect nitrate concentrations in valley and upland ground waters.

Other natural factors that can alter the quality of ground water are chemical and biological mechanisms that transform, and in some instances remove, contaminants or constituents present in the water. An example is denitrification, which is a process whereby nitrate in ground water is converted to nitrous oxide and nitrogen gas (Korm, 1992). A conceptual model of how land use and other factors affect ground-water quality in the study area is illustrated in figure 20 .

\section{Effects of Land-Use Activities on Water Quality}

One objective of this study was to characterize the quality of ground water in the aquifers of the study area. As a result; the data collected were not sufficient to determine local areas of contamination or to make a detailed analysis of the spatial relation between land use and underlying ground-water quality in the study area. For example, boron, TOC, and MBAS samples, which were collected as potential indicators of contamination by septic systems, did not prove useful because the number of samples in shallow ground water were too few. The effects of land-use activities on ground-water quality are indicated, however, by elevated concentrations of nitrate in shallow ground water, increasing concentrations of nitrate and chloride over time in water discharged from Maplewood Spring, and the presence of pesticides, VOCs, and bacteria in some wells and springs.

\section{Nitrate}

Samples collected during this study were analyzed for nitrite plus nitrate, and this designation is used to identify data listed in tables and shown on figures. In most natural waters, nitrite is a short-lived intermediate species produced during the oxidation of ammonia to nitrate, and it is not usually present in significant quantities (Ebbert and others, 1995). For simplicity, the term nitrate, instead of nitrite plus nitrate, is used in the text of this report, and all concentrations are reported in units of milligrams per liter (mg/L) as nitrogen.

Concentrations of nitrate in the study area ranged from less than 0.05 to $6.4 \mathrm{mg} / \mathrm{L}$ (table 9 , fig. 21). The median concentration was $1.1 \mathrm{mg} / \mathrm{L}$, which is well below the primary maximum contaminant level for drinking water of $10 \mathrm{mg} / \mathrm{L}$. The highest concentrations of nitrate were found in shallow ground water. However, concentrations of nitrate in shallow ground water in the Puyallup River Valley were low. Denitrification (the conversion of nitrate to nitrous oxide and nitrogen gas) is probably the primary cause of low nitrate concentrations in ground water sampled in the Puyallup River Valley, although this was not confirmed by this study. A more detailed discussion of denitrification, the relation between depth to ground water and nitrate concentrations, and differences between valley and upland wells is presented later in the section Other Factors Affecting Water Quality. 


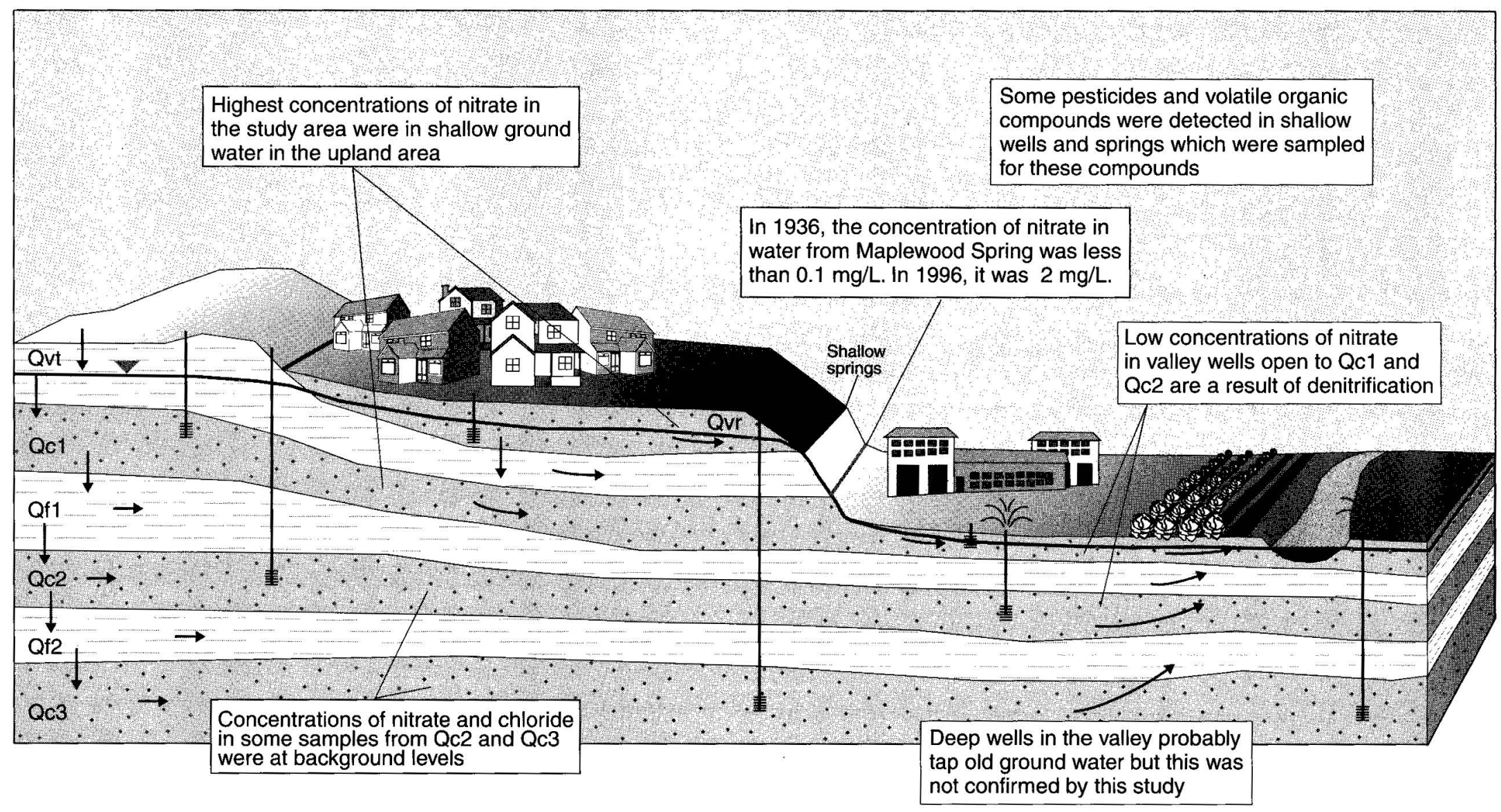

Figure 20. Overview of ground-water quality and factors affecting it. 


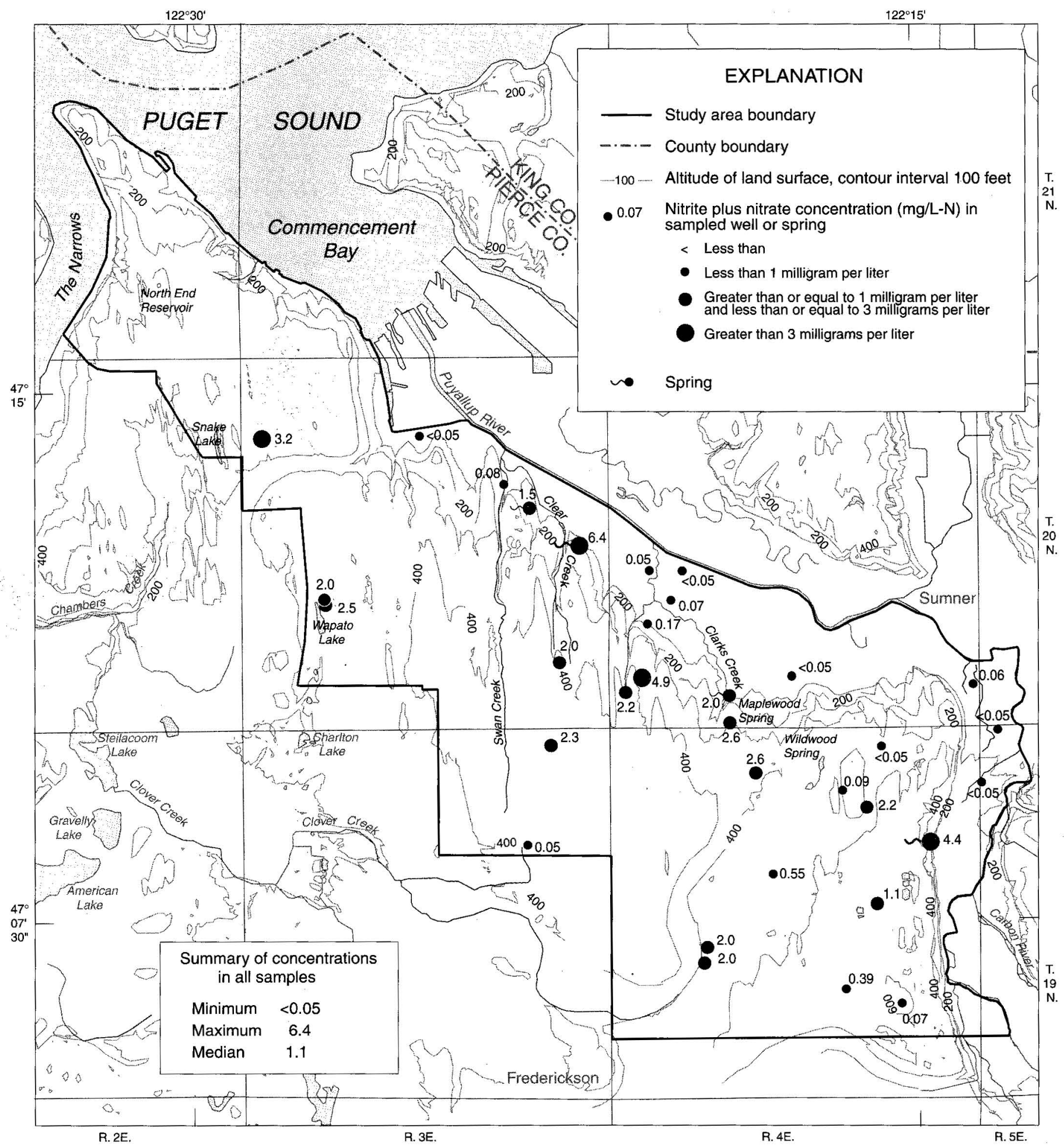

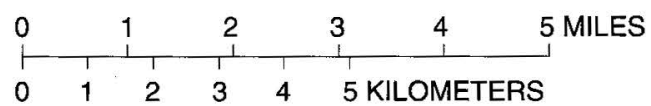

Figure 21. Concentrations of nitrite plus nitrate in water sampled from wells and springs, 1996 in the Tacoma-Puyallup area, Washington. 
An increase over time in concentrations of nitrate and chloride in water discharged from Maplewood Spring (fig. 22) is an indication that land-use activities have affected ground-water quality in the study area. In 1936, the concentrations of nitrate and chloride in the spring water were $0.09 \mathrm{mg} / \mathrm{L}$ and $2.0 \mathrm{mg} / \mathrm{L}$, respectively (table 10). When the USGS sampled the spring in 1996, the concentration of nitrate was $2 \mathrm{mg} / \mathrm{L}$, and the concentration of chloride was $5.4 \mathrm{mg} / \mathrm{L}$.

The years 1988-1994 were selected for a statistical test to determine if there is a trend in concentrations of nitrate in water from Maplewood Spring during recent years. These years were selected because they bracket the period over which samples were collected frequently by the City of Puyallup (Doug Maclean, City of Puyallup, written commun., 1996).

A distribution-free test, Kendall's Tau (Kendall, 1995), was used for trend testing. The null hypothesis for this test is that the random variable (concentration) is independent of time. In this test, all possible pairs of data values are compared; if the later value (in time) is higher, a plus is scored; if the later value is lower, a minus is scored. If there is no trend in the data, the odds are 50-50 that a value is higher (or lower) than one of its predecessors. In the absence of a trend, the number of pluses should be about the same as the number of minuses. Tau, the test statistic, is equal to zero if the number of pluses equals the number of minuses. If, however, there are many more pluses than minuses, the values later in the series are more frequently higher than those earlier in the series, and so an uptrend is likely. Similarly, if there are many more minuses than pluses, a downtrend is likely. If all the differences are positive, tau $=1$; if they are all negative, tau $=-1$.
In addition, the magnitude of the trend was estimated as the median of the differences (expressed as slopes) of the ordered pairs of data values compared using Kendall's Tau test. Although the magnitude of the trend is expressed as a slope (value per unit time), it does not imply a linear trend (Hirsch and others, 1982).

Results (fig. 23) indicate an increasing trend in the concentration of nitrate in water from Maplewood Spring, with a median slope of +0.05 milligrams per liter per year. Two questionable concentrations of less than $0.2 \mathrm{mg} / \mathrm{L}$ (table 10) were not included in the trend test.

Two additional Kendall's Tau tests were performed: one for the period 1988-1994, including the two questionable concentrations; and one for the period 1975-1997, also including the two questionable concentrations. Results shown below indicate a significant upward trend for all tests.

\section{Pesticides and Volatile Organic Compounds}

Pesticides were detected in 5 of 12 ground-water samples (fig. 24). The five samples with detections represent shallow ground waters collected from a spring and from four wells with depths to first openings ranging from 22 to 86 feet below land surface. This study targeted shallow ground water for pesticide determinations. Available data suggest that deep ground water in the study area is unlikely to contain pesticides. No pesticides were detected in samples from three deeper wells in the study area that were collected during a 1994 study of pesticides in public-supply wells (Ryker and Williamson, 1996). Depths to first openings in those wells ranged from 216 to 552 feet below land surface.

\begin{tabular}{lcrll}
\hline & & & \multicolumn{3}{c}{$\begin{array}{l}\text { Median slope } \mathrm{NO}_{3}-\mathrm{N} \\
\text { (milligrams per liter } \\
\text { Test period }\end{array}$} & Tau & p-value & per year) & \multicolumn{1}{c}{ Remarks } \\
\hline $1988-94$ & 0.86 & 0.01 & 0.05 & Without questionable concentrations \\
$1988-94$ & 0.86 & 0.01 & 0.07 & With questionable concentrations \\
$1975-97$ & 0.88 & $<0.01$ & 0.06 & With questionable concentrations \\
\hline
\end{tabular}




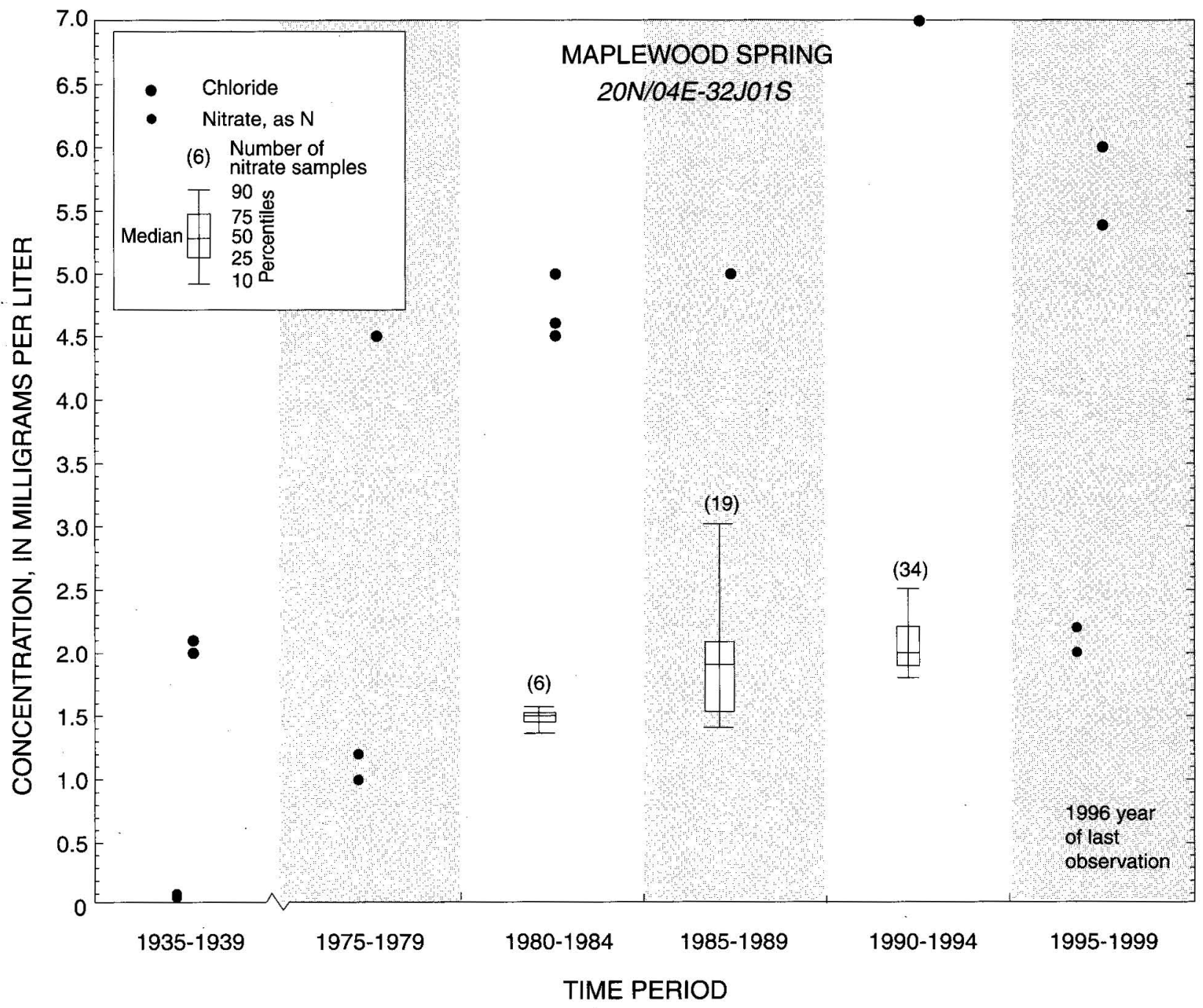

Figure 22. Trends in concentrations of nitrate and chloride in water from Maplewood Spring, 1936-96 in the Tacoma-Puyallup area, Washington. 
Table 10.--Concentrations of nitrate and chloride in water from Maplewood Spring, in the Tacoma-Puyallup area, Washington

[U, unknown; B, before treatment; A, after treatment; <, less than; USGS, U.S. Geological Survey Laboratory; DOH, Washington State Department of Health Laboratory; LTL, Laucks Testing Laboratories, Seattle Washington; WML, Water Management Laboratories, Tacoma, Washington; Analytical methods for nitrate: I-2545-78 cadmium reduction (Skougstad and others, 1979); $418 \mathrm{C}$ cadmium reduction (American Public Health Association, 1981, 1985); 418 F cadmium reduction (American Public Health Association, 1985); 4110 B ion chromatography (American Public Health Association, 1992); I-2545-85 cadmium reduction (Fishman and Friedman, 1989); Analytical methods for chloride: 407 A argentometric method (American Public Health Association, 1971, 1981, 1985); 407 B mercuric nitrate method (American Public Health Association, 1985); I-2187-78 ferric thiocyanate automated (Skougstad and others, 1979); I-2057-85 ion chromatography (Fishman and Friedman, 1989); 4110B ionchromatography (American Public Health Association, 1992)]

\begin{tabular}{|c|c|c|c|c|c|c|}
\hline $\begin{array}{l}\text { Sample } \\
\text { collection } \\
\text { date }\end{array}$ & $\begin{array}{l}\text { Collection } \\
\text { location }\end{array}$ & Laboratory & $\begin{array}{l}\text { Nitrate } \\
(\mathrm{mg} / \mathrm{L} \text { as } \mathrm{N})\end{array}$ & $\begin{array}{l}\text { Analytical } \\
\text { method for } \\
\text { nitrate }\end{array}$ & $\begin{array}{l}\text { Chloride } \\
(\mathrm{mg} / \mathrm{L})\end{array}$ & $\begin{array}{l}\text { Analytical } \\
\text { method for } \\
\text { chloride }\end{array}$ \\
\hline $10 / 20 / 36$ & $\mathrm{U}$ & USGS & 0.09 & unknown & 2.0 & unknown \\
\hline $1 / 11 / 38$ & $\mathrm{U}$ & USGS & 0.07 & unknown & 2.1 & unknown \\
\hline $4 / 29 / 75$ & B & $\mathrm{DOH}$ & 1.0 & unknown & 4.5 & $407 \mathrm{~A}$ \\
\hline $4 / 3 / 78$ & B & LTL & 1.2 & unknown & no sample & -. \\
\hline $9 / 2 / 81$ & B & DOH & 1.3 & $418 \mathrm{C}$ & no sample & -- \\
\hline $2 / 15 / 84$ & B & USGS & 1.5 & I-2545-78 & 4.6 & I-2187-78 \\
\hline $5 / 29 / 84$ & B & USGS & 1.6 & I- $2545-78$ & 4.5 & I-2187-78 \\
\hline $6 / 25 / 84$ & B & $\mathrm{DOH}$ & 2.0 & $418 \mathrm{C}$ & 5.0 & $407 \mathrm{~A}$ \\
\hline $8 / 27 / 84$ & B & USGS & 1.6 & I- $2545-78$ & no sample & -- \\
\hline $3 / 9 / 87$ & B & $\mathrm{DOH}$ & 1.6 & $418 \mathrm{~F}$ & 5.0 & $407 \mathrm{~A}$ \\
\hline $4 / 12 / 88$ & B & WML & 1.9 & $418 \mathrm{C}$ & no sample & -- \\
\hline $5 / 12 / 88$ & B & WML & $<0.2$ & $418 \mathrm{C}$ & no sample & -- \\
\hline $6 / 13 / 88$ & A & WML & 1.5 & $418 \mathrm{C}$ & no sample & -- \\
\hline $7 / 25 / 88$ & B & WML & 2.0 & $418 \mathrm{C}$ & no sample & -- \\
\hline $8 / 24 / 88$ & A & WML & 1.9 & $418 \mathrm{C}$ & no sample & -- \\
\hline $9 / 19 / 88$ & B & WML & 2.4 & $418 \mathrm{C}$ & no sample & -- \\
\hline $10 / 17 / 88$ & B & WML & 1.6 & $418 \mathrm{C}$ & no sample & -- \\
\hline $11 / 14 / 88$ & B & WML & 1.9 & $418 \mathrm{C}$ & no sample & -- \\
\hline $12 / 19 / 88$ & B & WML & 1.6 & $418 \mathrm{C}$ & no sample & - \\
\hline $1 / 23 / 89$ & B & WML & $<0.2$ & $418 \mathrm{C}$ & no sample & -- \\
\hline $2 / 21 / 89$ & B & WML & 1.8 & $418 \mathrm{C}$ & no sample & -- \\
\hline $3 / 21 / 89$ & B & WML & 4.4 & $418 \mathrm{C}$ & no sample & -- \\
\hline $4 / 17 / 89$ & B & WML & 3.5 & $418 \mathrm{C}$ & no sample & -- \\
\hline $5 / 23 / 89$ & B & WML & 2.1 & $418 \mathrm{C}$ & no sample & -- \\
\hline $6 / 19 / 89$ & B & WML & 2.8 & $418 \mathrm{C}$ & no sample & - \\
\hline $7 / 17 / 89$ & B & WML & 2.0 & $418 \mathrm{C}$ & no sample & -- \\
\hline $8 / 22 / 89$ & B & WML & 1.4 & $418 \mathrm{C}$ & no sample & -- \\
\hline $9 / 18 / 89$ & B & WML & 1.5 & $418 \mathrm{C}$ & no sample & -- \\
\hline $10 / 16 / 89$ & B & WML & 1.4 & $418 \mathrm{C}$ & no sample & -- \\
\hline $11 / 21 / 89$ & B & WML & 1.9 & $418 \mathrm{C}$ & no sample & -- \\
\hline
\end{tabular}


Table 10.--Concentrations of nitrate and chloride in water from Maplewood Spring, in the Tacoma-Puyallup area, Washington--Continued

\begin{tabular}{|c|c|c|c|c|c|c|}
\hline $\begin{array}{l}\text { Sample } \\
\text { collection } \\
\text { date }\end{array}$ & $\begin{array}{l}\text { Collection } \\
\text { location }\end{array}$ & Laboratory & $\begin{array}{l}\text { Nitrate } \\
(\mathrm{mg} / \mathrm{L} \text { as } \mathrm{N})\end{array}$ & $\begin{array}{l}\text { Analytical } \\
\text { method for } \\
\text { nitrate }\end{array}$ & $\begin{array}{l}\text { Chloride } \\
\text { (mg/L) }\end{array}$ & $\begin{array}{l}\text { Analytical } \\
\text { method for } \\
\text { chloride }\end{array}$ \\
\hline $12 / 18 / 89$ & B & WML & 1.1 & $418 \mathrm{C}$ & no sample & -- \\
\hline $1 / 16 / 90$ & B & WML & 1.9 & $418 \mathrm{C}$ & no sample & -- \\
\hline $1 / 22 / 90$ & B & WML & 2.0 & $418 \mathrm{C}$ & no sample & -- \\
\hline $2 / 20 / 90$ & B & WML & 1.8 & $418 \mathrm{C}$ & no sample & -- \\
\hline $3 / 19 / 90$ & B & WML & 1.8 & $418 \mathrm{C}$ & no sample & -- \\
\hline $4 / 16 / 90$ & B & WML & 1.9 & $418 \mathrm{C}$ & no sample & -- \\
\hline $5 / 21 / 90$ & B & WML & 2.1 & $418 \mathrm{C}$ & no sample & -- \\
\hline $6 / 18 / 90$ & B & WML & 2.0 & $418 \mathrm{C}$ & no sample & -- \\
\hline $7 / 23 / 90$ & B & WML & 1.9 & $418 \mathrm{C}$ & no sample & -- \\
\hline $8 / 20 / 90$ & B & WML & 2.6 & $418 \mathrm{C}$ & no sample & -- \\
\hline $9 / 24 / 90$ & B & WML & 2.0 & $418 \mathrm{C}$ & no sample & -- \\
\hline $11 / 20 / 90$ & B & WML & 0.6 & $418 \mathrm{C}$ & no sample & -- \\
\hline $12 / 18 / 90$ & B & WML & 2.0 & $418 \mathrm{C}$ & no sample & -- \\
\hline 1/21/91 & B & WML & 2.8 & $418 \mathrm{C}$ & no sample & -- \\
\hline $2 / 19 / 91$ & $\mathrm{U}$ & WML & 2.2 & $418 \mathrm{C}$ & no sample & -- \\
\hline $3 / 18 / 91$ & B & WML & 2.1 & $418 \mathrm{C}$ & no sample & -- \\
\hline $4 / 22 / 91$ & B & WML & 1.9 & $418 \mathrm{C}$ & no sample & -- \\
\hline $5 / 20 / 91$ & B & WML & 2.2 & $418 \mathrm{C}$ & no sample & -- \\
\hline $6 / 17 / 91$ & B & WML & 1.6 & $418 \mathrm{C}$ & no sample & -- \\
\hline $7 / 22 / 91$ & B & WML & 2.5 & $418 \mathrm{C}$ & no sample & -- \\
\hline $8 / 26 / 91$ & B & WML & 1.9 & $418 \mathrm{C}$ & no sample & -- \\
\hline $9 / 24 / 91$ & $\mathrm{~B}$ & WML & 0.8 & $418 \mathrm{C}$ & no sample & -- \\
\hline $10 / 28 / 91$ & B & WML & 2.4 & $418 \mathrm{C}$ & no sample & -- \\
\hline $12 / 16 / 91$ & B & WML & 2.0 & $418 \mathrm{C}$ & no sample & -- \\
\hline $2 / 18 / 92$ & B & WML & 2.1 & $418 \mathrm{C}$ & no sample & -- \\
\hline $4 / 20 / 92$ & $\mathrm{~B}$ & WML & 1.2 & $418 \mathrm{C}$ & no sample & -- \\
\hline $7 / 6 / 92$ & B & WML & 2.4 & $418 \mathrm{C}$ & no sample & -- \\
\hline $10 / 12 / 92$ & B & WML & 2.6 & $418 \mathrm{C}$ & no sample & -- \\
\hline $1 / 18 / 93$ & B & WML & 1.8 & $418 \mathrm{C}$ & no sample & -- \\
\hline $4 / 5 / 93$ & B & WML & 2.1 & $418 \mathrm{C}$ & no sample & -- \\
\hline $7 / 14 / 93$ & B & WML & 2.2 & $418 \mathrm{C}$ & 7.0 & $407 \mathrm{~B}$ \\
\hline $11 / 9 / 93$ & B & WML & 2.4 & $418 \mathrm{C}$ & no sample & -- \\
\hline $3 / 21 / 94$ & B & WML & 1.9 & $418 \mathrm{C}$ & no sample & - \\
\hline $6 / 27 / 94$ & B & WML & 2.2 & $418 \mathrm{C}$ & no sample & -- \\
\hline $9 / 11 / 95$ & B & WML & 2.2 & $4110 \mathrm{~B}$ & no sample & -- \\
\hline $6 / 18 / 96$ & B & USGS & 2.0 & I- $2545-85$ & 5.4 & I-2057-85 \\
\hline $8 / 15 / 96$ & B & WML & 2.5 & $4110 \mathrm{~B}$ & 6.0 & $4110 \mathrm{~B}$ \\
\hline $10 / 10 / 97$ & B & WML & 2.7 & $4110 \mathrm{~B}$ & no sample & -- \\
\hline
\end{tabular}




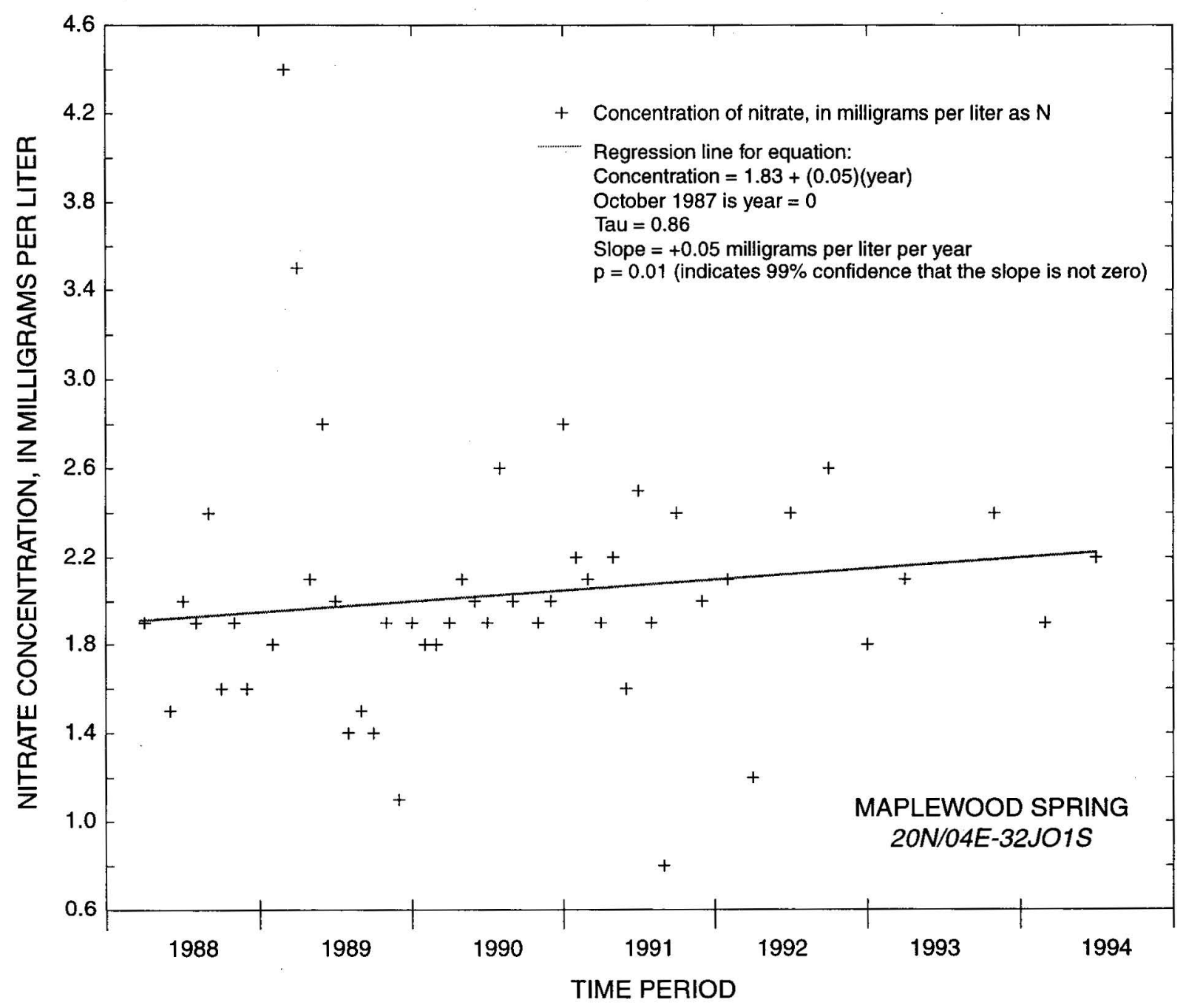

Figure 23. Trend in concentration of nitrate in water from Maplewood Spring 1988-94 in the Tacoma-Puyallup area, Washington. Sources of data are listed in table 10. 

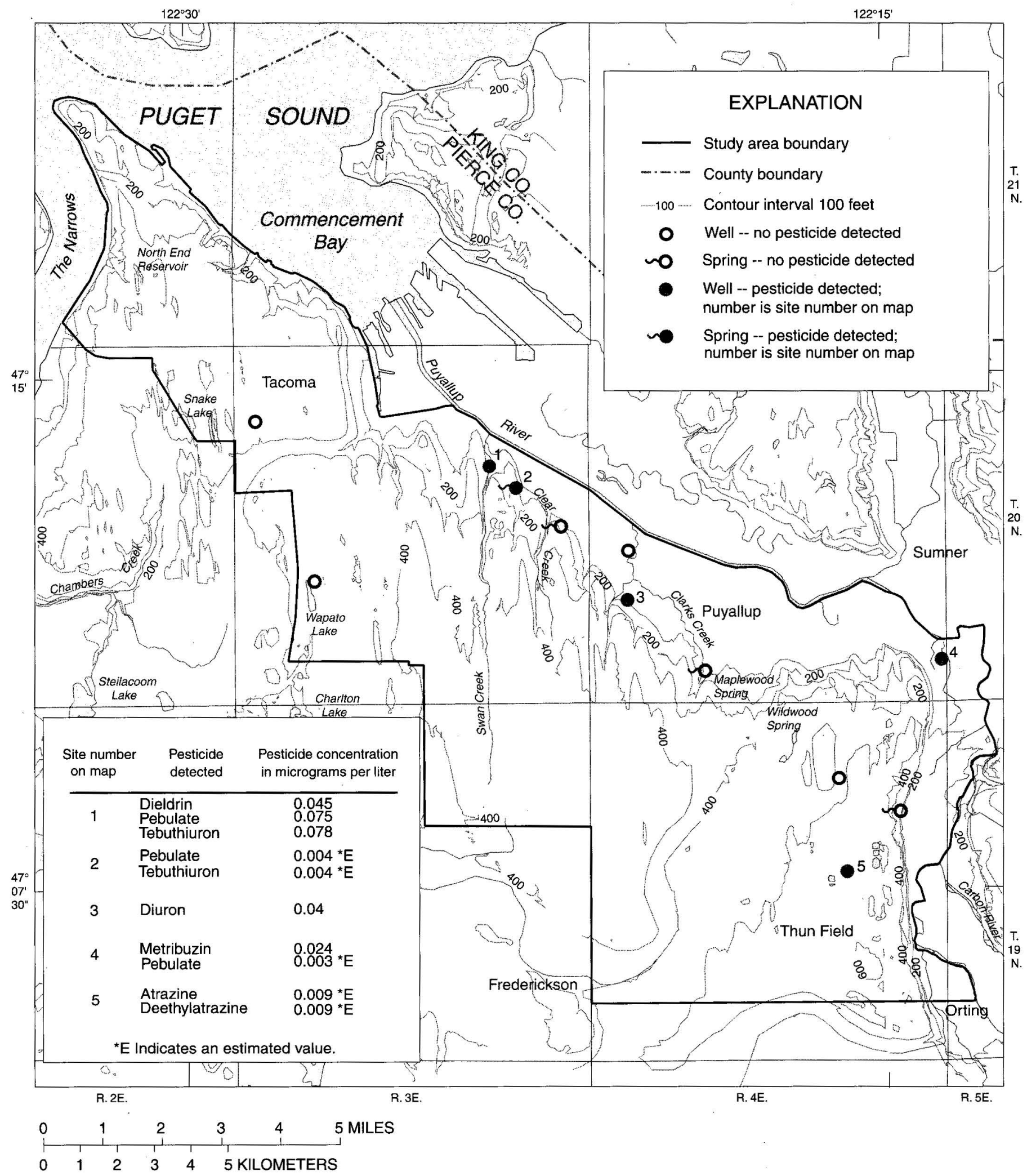

Figure 24. Locations of wells and springs sampled for pesticides and where pesticides were detected, 1996 in the TacomaPuyallup area, Washington. 
Dieldrin, an organochlorine insecticide, was detected in one sample at a concentration of $0.045 \mu \mathrm{g} / \mathrm{L}$ (micrograms per liter), which violated the drinking water guideline (table 9). In addition to its direct use as an insecticide, dieldrin is also a break-down product of the insecticide aldrin. The EPA suspended nearly all uses of aldrin and dieldrin in 1974, so the detection of dieldrin in the study area most likely reflects historic rather than current application patterns. Organochlorine compounds, like dieldrin, have a strong affinity for natural organic matter in soils, and it has traditionally been assumed that they are unlikely to migrate to ground waters. However, frequent detections of these compounds in well waters in other areas indicate that affinity for organic matter is an unreliable indicator of whether an individual pesticide will reach ground waters (Barbash and Resek, 1996). Dieldrin was the only pesticide detected that violated drinking water guidelines (table 9).

Pebulate, a thiocarbamate herbicide, was detected at concentrations ranging from 0.003 to $0.075 \mu \mathrm{g} / \mathrm{L}$ in water from two wells and one spring. It is a preplant herbicide effective on grassy and broadleaf weeds. Because pebulate is not one of the most heavily used herbicides in the Puget Sound region (Bortleson and Davis, 1997), its detection in three samples may reflect local usage patterns.

Tebuthiuron, detected at a concentration of $0.078 \mu \mathrm{g} / \mathrm{L}$ in water from one well and at a concentration of $0.004 \mu \mathrm{g} / \mathrm{L}$ in water from one spring, is a broad spectrum urea herbicide used to control weeds on noncropland areas, rangelands, rights-of way, and industrial sites (Meister Publishing Company, 1994). Tebuthiuron has all the characteristics of a material with a high potential for ground-water contamination. It is highly soluble, absorbs only weakly to soil particles, and is highly persistent in soils. It has, in fact, been detected frequently in ground waters of the United States; it was the fourth most detected pesticide in ground-water samples collected by the USGS in 10 urban areas during 1993-1995 (Kolpin and others, 1998). It is one of the most heavily used herbicides in the Puget Sound region (Bortleson and Davis, 1997).

The herbicides atrazine, diuron, and metribuzin were each detected once, and desethylatrazine, a break-down product of atrazine, was also detected once (fig. 24). Atrazine and metribuzin are triazine herbicides, which are often found in ground water, especially in the agricultural areas where corn is grown (Barbash and Resek, 1996). Neither is used heavily in the Puget Sound region. Diuron, a urea herbicide used to control weeds on both crop and noncrop areas, is heavily used in the Puget Sound region and has been detected in surface waters of the region (Bortleson and Davis, 1997).
The same 12 wells and springs that were sampled for pesticides were sampled for VOCs. The only compound detected was 1,1,1-trichloroethane, and it was detected at low concentrations in water from one well and one spring (fig. 25). Trichloroethane, a cleaning solvent, is ubiquitous in the environment and is often one of the more frequently detected VOCs in ground water underlying urban areas (Daly and Lindsey, 1996; Fenelon and Moore, 1996).

\section{Bacteria}

Samples from 33 wells and springs were analyzed to determine the presence of total-coliform, Escherichia coli (E. coli), and fecal-streptococci bacteria. Although some strains of $E$. coli are pathogenic, these bacteria are not typically disease-causing and are used as indicators of water-borne pathogens. Although all three groups of bacteria are found in the intestinal tract of humans and warm-blooded animals, total-coliform and fecalstreptococci bacteria are not restricted to this habitat. The presence of $E$. coli in water, however, is direct evidence of fecal contamination from warm-blooded animals.

Bacteria were detected in water from 9 of 33 sampled wells and springs, and $E$. coli were found in four samples (fig. 26). Most, but not all, of the detections were in samples from wells and springs tapping shallow ground water underlying coarse-grained surficial deposits. Figure 7 shows the distribution of coarse-grained surficial deposits in the study area. One would expect more detections in this environment because pathways for bacteria to enter ground water are shorter and more conductive than those to deep ground water underlying fine-grained surficial deposits.

\section{Other Factors Affecting Water Quality}

Because nitrate in ground water is usually derived from sources at or near the land surface, nitrate concentrations in ground water underlying developed areas usually decrease with depth and distance down flowpaths (Mueller and others, 1995). This relation was observed in the upland part of the study area, where highest concentrations of nitrate were in shallow ground water, and low concentrations (less than $1 \mathrm{mg} / \mathrm{L}$ ) were mostly in the deepest sampled ground water (fig. 27). In contrast, nitrate concentrations were low (ranging from less than 0.05 to $0.08 \mathrm{mg} / \mathrm{L}$ ) in both shallow and deep ground waters sampled in the Puyallup River Valley (fig. 21). 


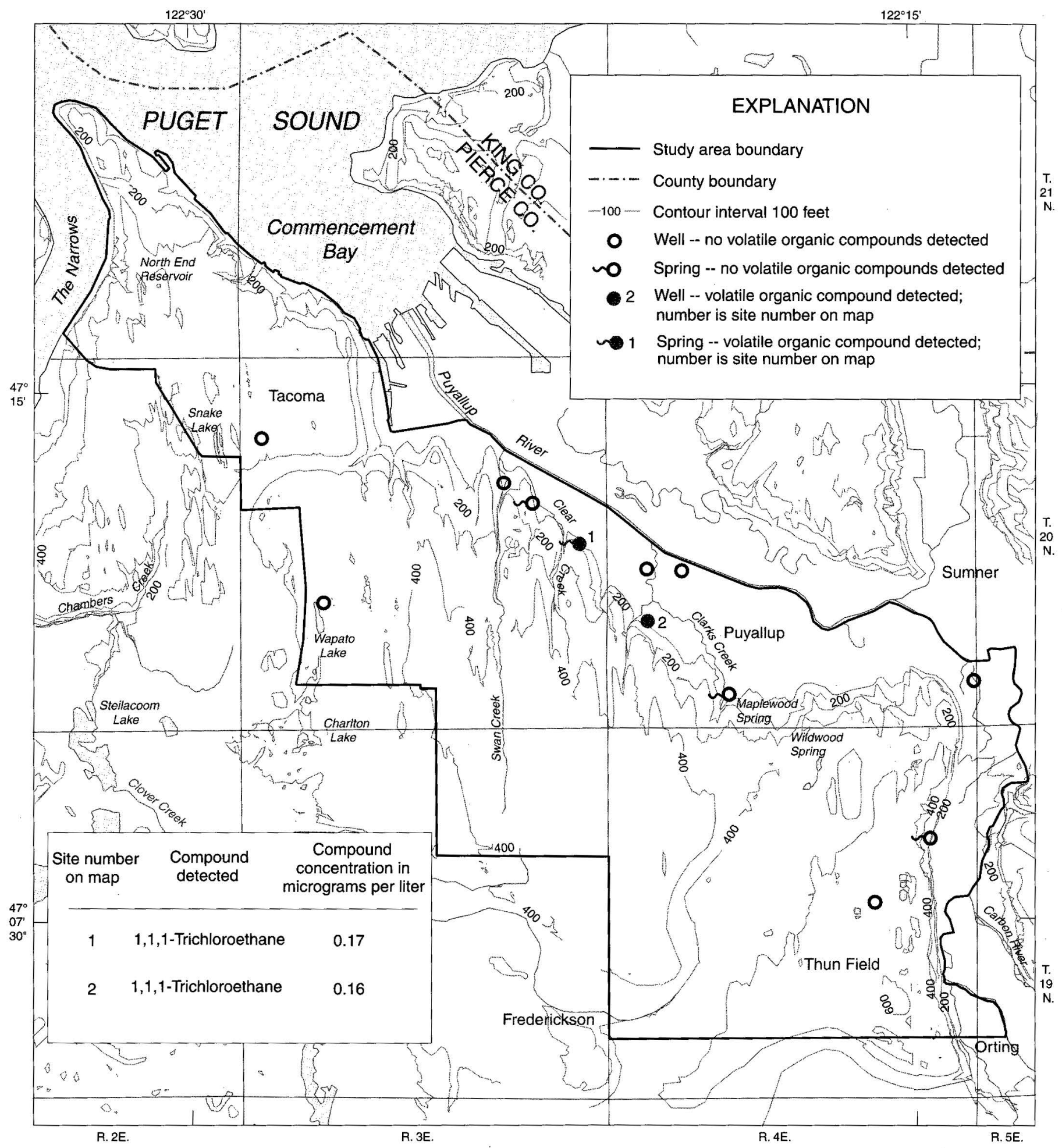

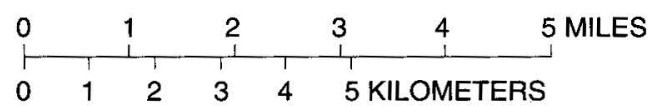

Figure 25. Locations of wells and springs sampled for volatile organic compounds (VOCs) and where VOCs were detected, 1996 in the Tacoma-Puyallup area, Washington. 


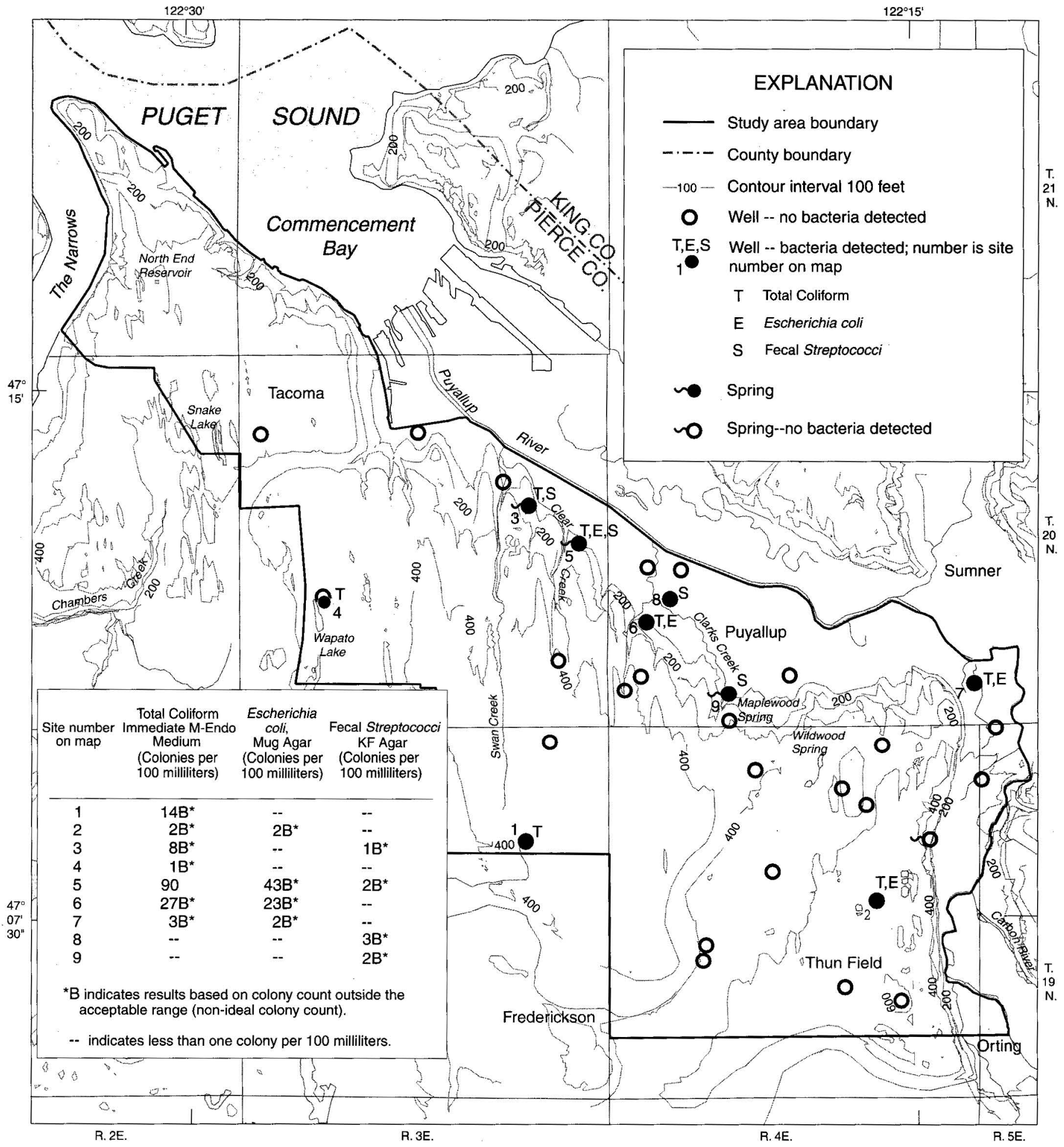

$\begin{array}{lllllll}0 & & 1 & 2 & 3 & 4 & 1 \\ 0 & 1 & 2 & 3 & 4 & 5 \text { KILOMETERS }\end{array}$

Figure 26. Locations of wells and springs sampled for bacteria and where bacteria were detected, 1996 in the TacomaPuyallup area, Washington. 

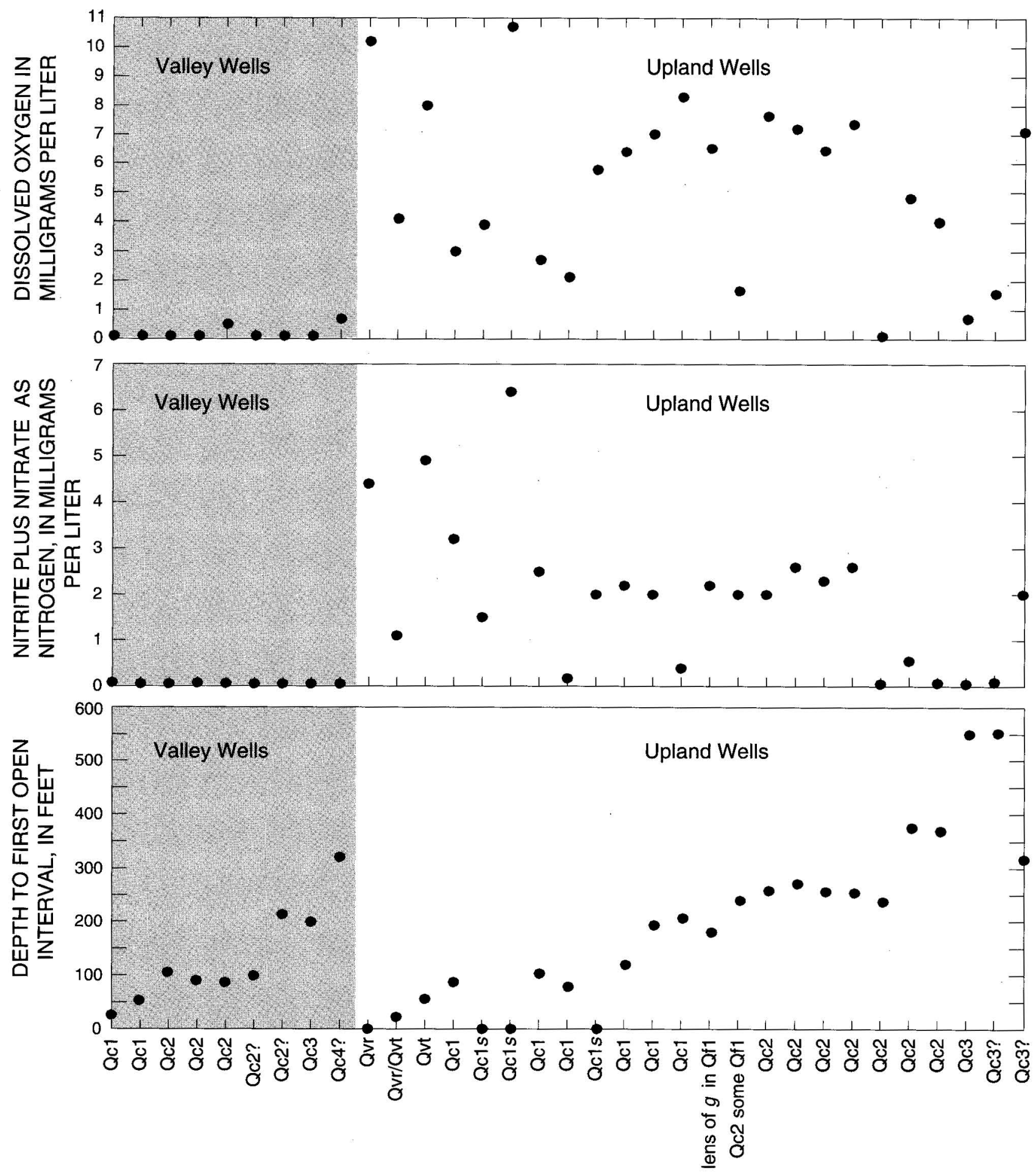

Water samples from wells completed in defined hydrogeologic units

Qvr Shallow aquifer; $s$ designates spring

Qvt Upper semiconfined unit

Qc1 Upper confined aquifer; $s$ designates spring

Qf1 Semiconfined unit below Qc1; $g$ designates gravel
Qc2 Second confined aquifer

Qc3 Third confined aquifer

Qc4 Fourth confined aquifer

Figure 27. Relation between hydrogeologic unit and depth to the first opening, concentrations of nitrate, and dissolved oxygen in the Tacoma-Puyallup area, Washington. 
Low concentrations of nitrate in shallow Puyallup River Valley ground water, particularly in water from wells open at less than $150 \mathrm{ft}$ below land surface, do not imply the lack of nitrogen sources or the lack of nitrogen compounds in ground water, but instead result from the absence of dissolved oxygen in the ground water (fig. 27)--a condition that is unfavorable for the presence of nitrate. The absence of dissolved oxygen in the shallow ground water is most likely because of the oxidation by bacteria of carbon present in the valley sediments. If enough carbon is available, all of the oxygen is depleted, and in the absence of oxygen, reduced nitrogen compounds like ammonia are not converted to nitrate, and nitrate can be removed by denitrification or reduction (Korm, 1992). This study did not investigate the occurrence of carbon in valley sediments, but accumulations of decomposed vegetal material resembling peat or muck are known to occur locally in the alluvial sediments of larger streams in central Pierce County (Walters and Kimmel, 1968). The drillers' logs for two of nine valley wells sampled during this study (20N/04E-33A01 and 20N/04E20E06) indicated the presence of layers of peat or wood in the sediments.

Alhajjar (1985) found that if oxygen was present in and downgradient from septic-system drain fields, ammonia produced by the decomposition of organic nitrogen was rapidly oxidized to nitrate. In the absence of oxygen, no conversion took place, and ammonia migrated from the drain fields to the underlying ground water. In a previous study of the lower Puyallup River Valley and adjacent uplands, Ebbert and others (1987) reported the presence of ammonia in some ground-water samples containing low concentrations of oxygen and nitrate. Concentrations of ammonia ranged from less than 0.01 to $19 \mathrm{mg} / \mathrm{L}$ as nitrogen; many of the detections were in the range of 1 to $3 \mathrm{mg} / \mathrm{L}$. Although that study did not determine if the ammonia was derived from septic systems, from the decomposition of nitrogenous organic matter deposited with the valley sediments, or from some other source, the finding was consistent with the hypothesis that low concentrations of dissolved oxygen in valley ground water retard the conversion of ammonia to nitrate.

Concentrations of nitrate in deep ground water in the Puyallup River Valley may be low because this is old ground water that has followed long flowpaths from the upland areas (see fig. 20). It is not known if any of the valley wells sampled intercept old ground water, but one would expect this water to contain little or no nitrate, like the deepest wells sampled in the upland areas. Old ground water was recharged at a time that predates development and probably never had high concentrations of nitrate.

\section{QUALITY ASSURANCE OF WATER-QUALITY DATA}

The quality-assurance plan for this study (M. A. Jones, U.S. Geological Survey, written commun., 1995) calls for quality-control procedures at all levels of data collection and analysis. Whereas many of the procedures address only methodology, some require the collection and analysis of quality-control samples. The resulting data are reviewed to determine the quality of the project data.

The water-quality data in this study was good, with some exceptions. Errors associated with most standard and duplicate samples were within project criteria for most constituents. Exceptions were large percentage errors from constituent concentrations near detection limits with otherwise small absolute errors. Concentrations in blanks, various internal sample checks, and comparisons of field and laboratory determinations were within acceptable limits for most constituents and samples. The results of the quality-assurance analyses did not affect any interpretations of ground-water-quality data.

In the following sections, data from standard reference samples, sample duplicates, blanks, cation-anion balance, and checks on field values are discussed.

\section{Standard Reference Samples}

Standard reference samples of various concentrations for selected inorganic constituents are routinely inserted as blind samples into the laboratory sample runs at the USGS NWQL, in Arvada, Colo. Each standard sample is submitted several times to obtain enough data to be statistically meaningful. Results are summarized and are available through computer programs maintained by the USGS's Branch of Quality Assurance (BQA) (Ludtke and Woodworth, 1997). The summary provides the mean concentration determined by the NWQL for each standard during a given period, along with the standard deviation of the laboratory concentrations, coefficient of variation, and number of times the standard was submitted and analyzed. These data for standards submitted from June 1 through July 31,1996 , were used to assess the error in the analytical accuracy of samples collected during that period from wells and springs in the study area. The standards used in the assessment were selected to bracket the range of concentrations in samples. In cases where that was not possible, those standards that best represented the sample concentrations were used. 
First, the standard deviation of the concentration of a standard reference sample from the true concentration was determined for each standard reference sample using the following equation:

$$
s_{i}=\sqrt{s_{s}^{2}+\left(\bar{u}_{s}-M P V_{s}\right)^{2}},
$$

where

$s_{i}=$ the standard deviation of the concentration of the standard reference sample from the true concentration;

$s_{s}=$ the standard deviation from the mean concentration determined by the NWQL;

$u_{s}=$ the mean concentration of the standard reference sample as determined by the NWQL; and

$M P V_{s}=$ the most probable value of the standard reference sample. This is an estimate of the true concentration of the standard reference sample based on the average result from as many as 150 independent laboratories.

Then equation 10 was used to determine the coefficient of variation $\left(C V_{i}\right)$ for the analysis of each standard:

$$
C V_{i}=\frac{s_{i}}{M P V_{s}}
$$

Then the overall coefficient of variation for a particular constituent was determined by averaging the squares of the coefficients of variation for all the standards that were in the range of concentrations found in the study area. This average was weighted by the number of times each standard was analyzed in the period as follows:

$$
C V_{o}=\sqrt{\frac{\sum_{i=1}^{m}\left(n_{i}-1\right) C V_{i}^{2}}{\sum_{i=1}^{m}\left(n_{i}-1\right)}},
$$

$$
\begin{aligned}
& \text { where } \\
& \begin{aligned}
& C V_{o}= \text { overall coefficient of variation of all standards } \\
& \text { for a constituent; }
\end{aligned} \\
& n_{i}=\begin{array}{c}
\text { number of times the standard was submitted and } \\
\text { analyzed; and }
\end{array} \\
& m=\text { number of standards. }
\end{aligned}
$$

The overall coefficient of variation was used to estimate the overall error of analysis of the standard reference samples for the constituent at the 95-percent confidence level. The following equation was used:

$$
E=\left(1.96 \times C V_{o}\right)^{100}
$$

where $E=$ overall error of analysis, in percent.

This error represents the average percent error in analytical accuracy of the samples from the study area and is shown in table 11 for each constituent. It also includes a degree of analytical precision. However, the accuracy and precision are difficult to separate in the given data, and in the interest of conservation, the error is considered to be entirely in the accuracy.

The average absolute standard deviation $\left(s_{0}\right)$ for each constituent, in units based on concentration, was calculated using equation 13 and is also shown in table 11.

$$
s_{o}=\sqrt{\frac{\sum_{i=1}^{m}\left(n_{i}-1\right) s_{i}^{2}}{\sum_{i=1}^{m}\left(n_{i}-1\right)}},
$$

The estimated errors for the common ions, silica, and nitrate determined in this study were generally reasonable. Quality-assurance goals for this study called for an error of 10 percent or less for these constituents. The average percent errors for calcium, magnesium, sodium, sulfate, and chloride met this goal (table 11). The average error for potassium of 40 percent was elevated because a value of $0.1 \mathrm{mg} / \mathrm{L}$ was reported for a standard with a $M P V$ of $5.72 \mathrm{mg} / \mathrm{L}$. If that one value is dropped from the error computation, then the average error of the analysis is 13 percent instead of 40 percent. The average error for fluoride of 52 percent was elevated in part because a value of $0.1 \mathrm{mg} / \mathrm{L}$ was reported for a standard with a $M P V$ of $0.41 \mathrm{mg} / \mathrm{L}$. If that one value is deleted from the error computation, then the average error of the analysis is 38 percent, which is the largest error (after adjustments) for the common ions, silica, and nitrate. The larger error for fluoride was a result of errors in the analysis of standards with concentrations close to the detection limit. The errors for silica and nitrate were 14 and 19 percent, respectively, and are probably representative. At these low concentrations, acceptable small absolute errors, as represented by 
Table 11.--Estimated error in analysis of inorganic constituents

[Concentrations in milligrams per liter unless otherwise noted. All are dissolved concentrations; $\mu \mathrm{g} / \mathrm{L}$, micrograms per liter]

\begin{tabular}{|c|c|c|c|c|c|c|c|c|c|c|}
\hline \multirow{2}{*}{$\begin{array}{l}\text { Constituent } \\
\text { Calcium }\end{array}$} & \multirow{2}{*}{$\begin{array}{c}\begin{array}{l}\text { Num- } \\
\text { ber of } \\
\text { stan- } \\
\text { dards }\end{array} \\
11\end{array}$} & \multirow{2}{*}{$\begin{array}{l}\text { Num- } \\
\text { ber of } \\
\text { times } \\
\text { stan- } \\
\text { dards } \\
\text { sub- } \\
\text { mitted }\end{array}$} & \multirow{2}{*}{$\begin{array}{l}\text { Median } \\
\text { concen- } \\
\text { tration in } \\
\text { ground- } \\
\text { water } \\
\text { samples } \\
16\end{array}$} & \multicolumn{3}{|c|}{$\begin{array}{l}\text { Range of } \\
\text { concen- } \\
\text { trations } \\
\text { in ground- } \\
\text { water samples }\end{array}$} & \multicolumn{2}{|c|}{$\begin{array}{l}\text { Range of } \\
\text { concen- } \\
\text { tration of } \\
\text { standards }\end{array}$} & $\begin{array}{l}\text { Average } \\
\text { absolute } \\
\text { standard } \\
\text { deviation } \\
\text { of } \\
\text { standards }\end{array}$ & \multirow{2}{*}{$\begin{array}{l}\begin{array}{l}\text { Average }^{\mathrm{a}} \\
\text { percent } \\
\text { error in } \\
\text { analysis }\end{array} \\
8.2\end{array}$} \\
\hline & & & & 7.4 & - & 39 & 6.60 & $-\quad 39.5$ & 0.56 & \\
\hline Magnesium & 9 & 38 & 7.7 & 2.4 & - & 21 & 2.00 & -14.5 & 0.26 & 8.3 \\
\hline Sodium & 3 & 12 & 7.0 & 4.4 & - & 20 & 11.8 & - 23.1 & 0.79 & 8.7 \\
\hline Potassium & 9 & 35 & 2.0 & 0.5 & - & 6.8 & 0.66 & - $\quad 7.83$ & 1.4 & 40 \\
\hline Sulfate & 2 & 7 & 5.2 & 0.3 & - & 23 & 19.1 & - $\quad 19.8$ & 0.53 & 10 \\
\hline Chloride & 3 & 11 & 5.4 & 1.6 & - & 10 & 7.06 & $-\quad 18.4$ & 0.48 & 10 \\
\hline Fluoride & 6 & 23 & $<0.1$ & $<0.1$ & - & 0.5 & 0.16 & $\begin{array}{ll}- & 0.59\end{array}$ & 0.14 & 52 \\
\hline Silica & 4 & 20 & 35 & 16 & - & 62 & 6.63 & $-\quad 10.4$ & 0.69 & 14 \\
\hline Nitrate & 2 & 32 & 1.1 & $<0.05$ & - & 6.4 & 0.24 & $\begin{array}{l}-\quad 0.78 \\
\end{array}$ & 0.04 & 19 \\
\hline Iron $(\mu \mathrm{g} / \mathrm{L})$ & 8 & 41 & 6 & $<3$ & - & 12,000 & 65.6 & -171 & 4.9 & 8.6 \\
\hline Manganese $(\mu \mathrm{g} / \mathrm{L})$ & 8 & 40 & 1 & $<1$ & - & 1,100 & 3.64 & -317 & 4.0 & 16 \\
\hline Arsenic $(\mu \mathrm{g} / \mathrm{L})$ & 3 & 11 & $<1$ & $<1$ & - & 10 & 2.95 & $\begin{array}{ll}- & 10.1\end{array}$ & 0.87 & 31 \\
\hline Barium $(\mu \mathrm{g} / \mathrm{L})$ & 3 & 17 & 4 & $<2$ & - & 24 & 15.5 & $-\quad 42.4$ & 1.3 & 14 \\
\hline Boron $(\mu \mathrm{g} / \mathrm{L})$ & 4 & 20 & 20 & 7.6 & - & 68 & 8.78 & - 28.7 & 2.4 & 47 \\
\hline Cadmium $(\mu \mathrm{g} / \mathrm{L})$ & 3 & 11 & $<1$ & $<1$ & - & $<1$ & 5.59 & - $\quad 33.8$ & 2.3 & 15 \\
\hline Chromium $(\mu \mathrm{g} / \mathrm{L})$ & 3 & 10 & $<1$ & $<1$ & - & $<1$ & 7.71 & $-\quad 18.1$ & 0.23 & 14 \\
\hline Copper $(\mu g / L)$ & 2 & 9 & $<1$ & $<1$ & - & 3 & 28.1 & -41.5 & 3.3 & 17 \\
\hline Lead $(\mu \mathrm{g} / \mathrm{L})$ & 2 & 5 & $<1$ & $<1$ & - & $<1$ & 2.18 & 9.39 & 0.41 & 16 \\
\hline Mercury $(\mu \mathrm{g} / \mathrm{L})$ & 3 & 12 & $<0.1$ & $<0.1$ & - & 0.1 & 0.35 & 1.16 & 0.15 & 29 \\
\hline Selenium $(\mu \mathrm{g} / \mathrm{L})$ & 4 & 13 & $<1$ & $<1$ & - & $<1$ & 4.95 & -15.6 & 0.93 & 31 \\
\hline Silver $(\mu \mathrm{g} / \mathrm{L})$ & 3 & 12 & $<1$ & $<1$ & - & $<1$ & 2.03 & $\begin{array}{l}-\quad 5.88 \\
\end{array}$ & 0.0 & 3.9 \\
\hline $\operatorname{Zinc}(\mu \mathrm{g} / \mathrm{L})$ & 4 & 19 & 3.5 & $<3$ & - & 88 & 26.2 & - $\quad 37.9$ & 4.2 & 34 \\
\hline
\end{tabular}

\footnotetext{
${ }^{\text {a }}$ At 95-percent confidence level. Computed using equations described in the text and data supplied by the U.S. Geological Survey's Branch of Quality Assurance. Error criterion is 10 percent for cations, anions, silica, dissolved solids, and nutrients. Error criterion is 20 percent for metals and trace elements.
} 
the absolute standard deviation, produce large percent errors. For example, an absolute error of $0.2 \mathrm{mg} / \mathrm{L}$ is a 20 -percent error for a concentration of $1.0 \mathrm{mg} / \mathrm{L}$, but is only a 2-percent error for a concentration of $10 \mathrm{mg} / \mathrm{L}$.

Errors for trace elements ranged from 3.9 to 47 percent (table 11). For 8 of 13 trace elements, the error was within the goal of 20 percent. Even though the average percent error was above 20 percent for five metals, the absolute error, as represented by the average absolute standard deviation, was generally reasonable. For some of the trace elements, copper and cadmium for example, the average absolute standard deviation was large relative to the range of concentrations in ground-water samples, but was acceptable relative to the range of concentrations in standards. Because concentrations of trace elements in standards were usually larger than concentrations in ground-water samples, the absolute standard deviation resulting from multiple analyses of actual samples probably would be smaller than those reported from analysis of standards.

Internal surrogate standards were injected into each sample to be analyzed for concentrations of VOCs or pesticides, and samples prepared with known concentrations of analytes (spiked samples) were analyzed during sample runs. The surrogate and spiked samples were used to determine percent recoveries, and those that were not detected within a certain percentage of the known concentrations (variable, dependent upon the compound) were identified by the NWQL. No samples were reported to have substandard VOC recoveries; however, recoveries of some pesticides were considered not acceptable. Pesticide compounds with poor recoveries or with other problems associated with their analysis are footnoted in tables 2 and 3 in the Water-Quality Methods section of this report.

\section{Duplicate and Replicate Samples}

Duplicate samples were analyzed for boron, nitrate, radon, and MBAS (table 12), and replicate samples were analyzed for bacteria (table 13). Overall the results were very good; however, one of the boron duplicate pairs did not meet the precision criteria of 10 percent outlined in the quality-assurance plan for this study (M. A. Jones, U.S. Geological Survey, written commun., 1995). Although no precision criteria were set for bacteria determinations, results of replicate analyses indicate generally good precision.

\section{Blanks}

Blanks of deionized water or specially prepared blank water were processed in the same manner as water samples and sent to the NWQL for analysis. Although no criteria were set for constituent concentrations in blanks, the significance of any constituent present in a blank was based on how close the constituent concentration was to the detection limit and how small it was compared with the median sample concentration. Also important was the number of times the constituent was detected in blank samples. These data are presented in table 14, and, when compared with these criteria, concentrations in blanks were insignificant for all constituents, but of possible concern for potassium, boron, and fecal-streptococci bacteria. Potassium was detected in only one of four blanks, but the reported concentration of $1.9 \mathrm{mg} / \mathrm{L}$ was large relative to the range of concentrations in groundwater samples of 0.5 to $6.8 \mathrm{mg} / \mathrm{L}$. Boron was detected at a concentration of $6.7 \mu \mathrm{g} / \mathrm{L}$ in one of the three blank samples. Six colonies of fecal-streptococci bacteria were detected in 100 milliliters in 1 of 18 blanks.

\section{Cation-Anion Balance}

Various sums, differences, and ratios based on the principles of aquatic chemistry were computed for each sample. These computations check the consistency between constituent concentrations in a sample and provide a gross check in the accuracy and completeness of the analysis. One of the most useful computations is the cation-anion balance, which is discussed in the following paragraphs.

The cation-anion balance was calculated as a percent difference, using the following equation:

$$
\frac{\sum \text { cations }-\sum \text { anions }}{\sum \text { cations }+\sum \text { anions }} \times 100 \text { percent }
$$

where

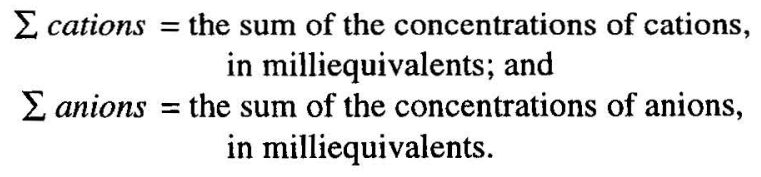


Table 12.--Constituent concentrations in duplicate samples

[Concentrations in milligrams per liter unless otherwise noted; $\mu \mathrm{g} / \mathrm{L}$, micrograms per liter; $\mathrm{pCi} / \mathrm{L}$, picocuries per liter; MBAS, methylene blue active substances; ,-- no data; $<$, less than]

\begin{tabular}{|c|c|c|c|c|c|c|c|c|}
\hline \multirow{2}{*}{$\begin{array}{l}\text { Well at which duplicate } \\
\text { was collected }\end{array}$} & \multicolumn{2}{|c|}{ Boron $(\mu \mathrm{g} / \mathrm{L})$} & \multicolumn{2}{|c|}{ Nitrate } & \multicolumn{2}{|c|}{ Radon $(\mathrm{pCi} / \mathrm{L})$} & \multicolumn{2}{|c|}{ MBAS } \\
\hline & Reported & Duplicate & Reported & Duplicate & Reported & Duplicate & Reported & Duplicate \\
\hline 19N/03E-11Q01 & -- & -- & . -- & -- & 460 & 450 & -- & - \\
\hline $19 \mathrm{~N} / 04 \mathrm{E}-02 \mathrm{~F} 01$ & -- & -- & -- & -- & 470 & 510 & -- & -- \\
\hline $19 \mathrm{~N} / 04 \mathrm{E}-20 \mathrm{~K} 03$ & 12.3 & 12.7 & 2 & 2 & -- & -- & $<0.02$ & $<0.02$ \\
\hline 20N/03E-07F01 & -- & -- & 3.2 & 3.2 & -- & -- & $<0.02$ & $<0.02$ \\
\hline $20 \mathrm{~N} / 04 \mathrm{E}-20 \mathrm{~N} 01$ & 22.8 & 18.7 & -- & -- & -- & -- & $<0.02$ & $<0.02$ \\
\hline 20N/04E-31F02 & 16.5 & 9.5 & -- & -- & -- & -- & -- & -- \\
\hline
\end{tabular}


Table 13.--Replicate sample results for bacteria determinations

$[--$, no data]

\begin{tabular}{|c|c|c|c|c|c|}
\hline \multirow[b]{2}{*}{$\begin{array}{l}\text { Local well } \\
\text { number }\end{array}$} & \multirow[b]{2}{*}{$\begin{array}{l}\text { Milliliters } \\
\text { filtered }\end{array}$} & \multirow[b]{2}{*}{$\begin{array}{l}\text { Replicate } \\
\text { number }\end{array}$} & \multicolumn{3}{|c|}{ Colony counts per plate } \\
\hline & & & $\begin{array}{l}\text { Fecal } \\
\text { Streptococci }\end{array}$ & $\begin{array}{l}\text { Total } \\
\text { coliform }\end{array}$ & $\begin{array}{l}\text { Escherichia } \\
\text { coli }\end{array}$ \\
\hline 19N/03E-11Q01 & 100 & $\begin{array}{l}1 \\
2 \\
3\end{array}$ & $\begin{array}{l}0 \\
0 \\
0\end{array}$ & $\begin{array}{r}2 \\
27 \\
12\end{array}$ & $\begin{array}{l}0 \\
0 \\
0\end{array}$ \\
\hline 19N/04E-12N01S & 100 & $\begin{array}{l}1 \\
2 \\
3 \\
1 \\
2 \\
3\end{array}$ & $\begin{array}{l}0 \\
0 \\
0 \\
0 \\
0 \\
0\end{array}$ & $\begin{array}{l}0 \\
0 \\
0 \\
0 \\
0 \\
0\end{array}$ & $\begin{array}{l}-- \\
-- \\
-- \\
-- \\
-- \\
--\end{array}$ \\
\hline 19N/04E-14P01 & 100 & $\begin{array}{l}1 \\
2 \\
3 \\
1 \\
2 \\
3\end{array}$ & $\begin{array}{l}2 \\
0 \\
0 \\
0 \\
0 \\
0\end{array}$ & $\begin{array}{l}0 \\
0 \\
2 \\
2 \\
4 \\
1\end{array}$ & $\begin{array}{c}-- \\
-- \\
2 \\
2 \\
4 \\
1\end{array}$ \\
\hline 19N/04E-20K03 & 100 & $\begin{array}{l}1 \\
2 \\
3\end{array}$ & $\begin{array}{l}0 \\
0 \\
0\end{array}$ & $\begin{array}{l}0 \\
0 \\
0\end{array}$ & $\begin{array}{l}-- \\
-- \\
--\end{array}$ \\
\hline 20N/03E-14H01S & 100 & $\begin{array}{l}1 \\
2 \\
3 \\
1 \\
2 \\
3\end{array}$ & $\begin{array}{l}1 \\
1 \\
0 \\
0 \\
2 \\
1\end{array}$ & $\begin{array}{r}3 \\
0 \\
1 \\
8 \\
8 \\
12\end{array}$ & $\begin{array}{c}0 \\
- \\
0 \\
0 \\
0 \\
0\end{array}$ \\
\hline 20N/04E-19G01 & 100 & $\begin{array}{l}1 \\
2 \\
3 \\
1 \\
2 \\
3\end{array}$ & $\begin{array}{l}0 \\
0 \\
0 \\
0 \\
0 \\
0\end{array}$ & $\begin{array}{l}0 \\
0 \\
0 \\
0 \\
0 \\
0\end{array}$ & $\begin{array}{l}-- \\
-- \\
-- \\
-- \\
-- \\
--\end{array}$ \\
\hline 20N/04E-20E06 & 100 & $\begin{array}{l}1 \\
2 \\
3\end{array}$ & $\begin{array}{l}0 \\
0 \\
--\end{array}$ & $\begin{array}{l}0 \\
0 \\
0\end{array}$ & $\begin{array}{l}-- \\
-- \\
--\end{array}$ \\
\hline 20N/04E-36H03 & 100 & $\begin{array}{l}1 \\
2 \\
3 \\
1 \\
2 \\
3\end{array}$ & $\begin{array}{l}0 \\
0 \\
1 \\
0 \\
0 \\
0\end{array}$ & $\begin{array}{l}1 \\
1 \\
3 \\
2 \\
1 \\
3\end{array}$ & $\begin{array}{l}1 \\
0 \\
2 \\
2 \\
0 \\
3\end{array}$ \\
\hline
\end{tabular}


Table 14.--Summary of constituent concentrations reported for blank samples

[Concentrations in milligrams per liter unless otherwise noted; $\mu \mathrm{g} / \mathrm{L}$, micrograms per liter; $\mathrm{pCi} / \mathrm{L}$, picocuries per liter; cols. per $100 \mathrm{~mL}$, colonies per 100 milliliters; ND, not detected]

\begin{tabular}{|c|c|c|c|c|}
\hline Constituent & $\begin{array}{l}\text { Number } \\
\text { of field } \\
\text { blanks }\end{array}$ & $\begin{array}{l}\text { Number of } \\
\text { equipment } \\
\text { blanks }\end{array}$ & $\begin{array}{l}\text { Number of } \\
\text { detections }\end{array}$ & $\begin{array}{l}\text { Maximum } \\
\text { concentration } \\
\text { in blank }\end{array}$ \\
\hline Calcium & 3 & 1 & 0 & ND \\
\hline Magnesium & 3 & 1 & 0 & ND \\
\hline Sodium & 3 & 1 & 0 & ND \\
\hline Potassium & 3 & 1 & 1 & 1.9 \\
\hline Alkalinity & 3 & 1 & 4 & 1.5 \\
\hline Sulfate & 3 & 1 & 0 & ND \\
\hline Chloride & 3 & 1 & 0 & ND \\
\hline Fluoride & 3 & 1 & 0 & ND \\
\hline Silica & 3 & 1 & 1 & 0.2 \\
\hline Nitrate & 3 & 1 & 1 & 0.06 \\
\hline Iron $(\mu \mathrm{g} / \mathrm{L})$ & 3 & 1 & 0 & ND \\
\hline Manganese $(\mu \mathrm{g} / \mathrm{L})$ & 3 & 1 & 0 & ND \\
\hline Arsenic $(\mu \mathrm{g} / \mathrm{L})$ & 1 & 1 & 0 & ND \\
\hline Barium $(\mu \mathrm{g} / \mathrm{L})$ & 1 & 1 & 0 & ND \\
\hline Boron $(\mu \mathrm{g} / \mathrm{L})$ & 2 & 1 & 1 & 6.7 \\
\hline Cadmium $(\mu \mathrm{g} / \mathrm{L})$ & 1 & 1 & 0 & ND \\
\hline Chromium $(\mu \mathrm{g} / \mathrm{L})$ & 1 & 1 & 0 & ND \\
\hline Copper $(\mu \mathrm{g} / \mathrm{L})$ & 1 & 1 & 0 & ND \\
\hline Lead $(\mu \mathrm{g} / \mathrm{L})$ & 1 & 1 & 0 & ND \\
\hline Mercury $(\mu \mathrm{g} / \mathrm{L})$ & 1 & 1 & 0 & ND \\
\hline Selenium $(\mu \mathrm{g} / \mathrm{L})$ & 1 & 1 & 0 & ND \\
\hline Silver $(\mu \mathrm{g} / \mathrm{L})$ & 1 & 1 & 0 & ND \\
\hline Zinc $(\mu \mathrm{g} / \mathrm{L})$ & 1 & 1 & 0 & ND \\
\hline Total organic carbon & 1 & 1 & 0 & ND \\
\hline Methylene Blue active substances & 1 & 1 & 0 & ND \\
\hline \multicolumn{5}{|l|}{ All other organic compounds } \\
\hline Volatiles $(\mu \mathrm{g} / \mathrm{L})$ & 1 & 1 & 0 & ND \\
\hline Pesticides $(\mu \mathrm{g} / \mathrm{L})$ & 1 & 0 & 0 & ND \\
\hline Total coliform (cols. per $100 \mathrm{~mL}$ ) & 10 & 10 & 1 & 1 \\
\hline Fecal Streptococci (cols. per $100 \mathrm{~mL}$ ) & 8 & 10 & 1 & 6 \\
\hline
\end{tabular}


Ideally, this value is zero, but nonzero values are common and may be large when a cation or anion concentration is in error or when an ion present in large concentrations (often a metal) is not analyzed for. The acceptable percent difference varies with the total sum of cations and anions, as shown in figure 28 . The cation-anion balance was acceptable for all of the samples collected in the study area.

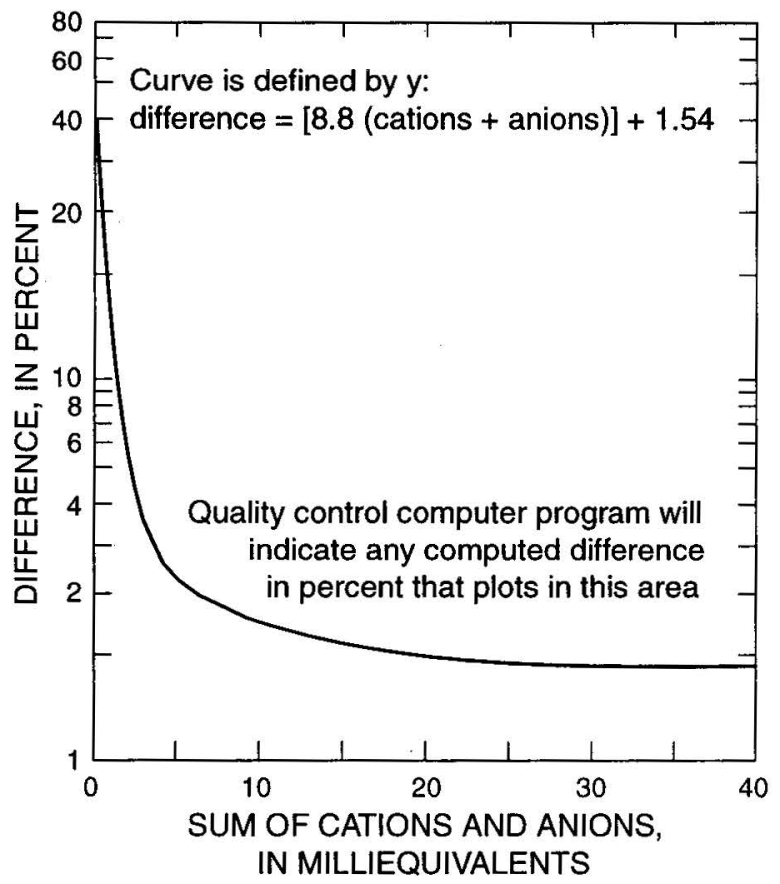

Figure 28. Cation and anion percent difference (Friedman and Erdmann, 1982).

\section{Checks on Field Values}

The primary controls on the determinations of field values of $\mathrm{pH}$, specific conductance, dissolved oxygen, and temperature are proper instrument calibration and field procedures. Specific conductance and $\mathrm{pH}$ are also determined in the laboratory. Laboratory determinations of $\mathrm{pH}$ values are made to evaluate samples that may require special processing and are not considered indicative of field values. Specific conductance is more stable, and laboratory values provide a good check of field values. Based on a paired t-test, there was no significant difference at the 95-percent confidence level between laboratory and field specific conductance values.

Alkalinity, which is part of the anion-cation balance, was also measured in the field. The acceptable balance for all determinations provides a check on this determination.

\section{SUMMARY AND CONCLUSIONS}

The study area, which encompasses $88 \mathrm{mi}^{2}$ of the northwestern portion of Pierce County, is a product of the last glaciation and more recent alluvial processes of the Quaternary Period. It consists of an upland drift plain that ranges in altitude from 200 to $600 \mathrm{ft}$ above sea level and has been transected by outwash channels and the Puyallup River Valley.

Subsurface stratigraphy of the unconsolidated deposits was correlated using lithologic information from published surficial geology maps, from the interpretation of 255 drillers' logs, and from 17 generalized hydrogeologic sections oriented north-south and east-west across the study area. Ten hydrogeologic units were delineated. They include five aquifers--Qvr, Qc1, Qc2, Qc3, and Qc4--consisting predominantly of coarse-grained glacial outwash and alluvium deposits. These units are separated by semiconfining units Qvt, Qf1, Qf2, Qf3, and Qf4, consisting predominantly of fine-grained till, clay, and silt deposits. These 10 units are underlain by an undifferentiated unconsolidated unit, Qdu, of unknown hydrologic characteristics more than $1,000 \mathrm{ft}$ thick. Maps were prepared depicting the configuration of the tops of the five uppermost hydrogeologic units, showing their general extent and geometry.

Unit Qvr is present at the land surface and generally represents the recessional outwash deposits of the Fraser Glaciation. It is considered an aquifer where saturated. The median thickness of this aquifer is $22 \mathrm{ft}$. Aquifer Qc1 generally lies beneath unit Qvt throughout the study area. Its median altitude and thickness within the study area are $238 \mathrm{ft}$ and $41 \mathrm{ft}$, respectively, with a median hydraulic conductivity of $110 \mathrm{ft} / \mathrm{d}$. Aquifer Qc2, the most widely used aquifer by public-supply purveyors, lies beneath semiconfining unit Qf1. Its median altitude and thickness are $55 \mathrm{ft}$ and $27 \mathrm{ft}$, respectively, with a median hydraulic conductivity of $170 \mathrm{ft} / \mathrm{d}$. Aquifer Qc3 lies beneath semiconfining unit Qf2. The top of this unit is generally below sea level, with a median altitude of $-128 \mathrm{ft}$. Few wells penetrate to this depth; from the available data, the thickness of this unit is estimated at $55 \mathrm{ft}$, and the hydraulic conductivity is estimated at $100 \mathrm{ft} / \mathrm{d}$. Some information was available for delineating hydrogeologic units Qf3, Qc4, and Qf4, but this information is sparse. In general all remaining undifferentiated deposits are grouped into a hydrogeologic unit designated Qdu. This unit also includes part of the other 10 units in areas at depth where there is no information available to delineate them. 
Maps of the water-level altitudes of aquifers Qc1 and Qc2 reflect the local and regional horizontal movement of the ground-water system, respectively. The pattern of ground-water movement in both aquifers is similar, with flow toward the east and northeast into the Puyallup River and north to Commencement Bay, The Narrows, and Puget Sound. Ground-water movement in aquifer Qc1 is also to the southwest through the Clover Creek Channel. Horizontal ground-water gradients in the southeast corner of the study area for Qc1 are about $100 \mathrm{ft} / \mathrm{mi}$. In this same area ground-water gradients for aquifer Qc2 are $150 \mathrm{ft} / \mathrm{mi}$ due to the steep topography in this area. Overall groundwater gradients for aquifer $\mathrm{Qc} 2$ are about $70 \mathrm{ft} / \mathrm{mi}$ throughout the study area. Vertical ground-water movement is downward in the upland part of the study area and upward in the lower reach of the Puyallup River Valley.

Most of the recharge to the local ground-water system is derived from the infiltration of precipitation and at depth from ground-water inflow from outside the studyarea boundaries. Recharge was estimated at $14 \mathrm{in} / \mathrm{yr}$ for the study area, based on the distribution of the annual precipitation, surficial geology, land use, and sanitary and stormwater systems. Ground-water movement across the study area boundaries was not quantified due to a lack of available data.

Spring-flow and baseflow from the creeks whose drainage basins are contained within the study area and from the water-wells was assessed to quantify some of the ground-water discharge in the area. The estimated average annual spring discharge totaled $14 \mathrm{ft}^{3} / \mathrm{s}$. This value is only considered a minimum estimate of the actual discharge from spring flow. The sum of baseflows in three creeks in the study area, Clarks, Clear, and Swan Creeks, was estimated at $59 \mathrm{ft}^{3} / \mathrm{s}$, based on the available hydrograph data from three continuous gaging stations.

Approximately 6,890 Mgal of ground water was withdrawn from the study area in 1996. About 97 percent of that total was for residential, commercial, and industrial purposes, with smaller amounts, about 3 percent, used for agriculture, aquaculture, irrigation, and system losses. Aquifer Qc1 supplied most $(2,790 \mathrm{Mgal})$ of the water, followed by Qc2 (2,320 Mgal), Qc3 (968 Mgal), Qc4 (497 Mgal), and from all remaining units (313 Mgal).

Based on the configuration of the study area and its general location in the regional ground-water system, the recharge to the ground-water system within the study area moves through the shallow ground-water system along relatively short flowpaths before being discharged to cliff faces as seeps and springs or to creeks. Assuming minimal ground-water inflow from outside the study area to these upper units, a local ground-water budget was approximated for the shallow ground-water system, units Qc1 and above. This local water budget indicates that 86 percent of the quantified recharge within the study area discharges through the shallow ground-water system. Thus, units in the shallow ground-water system constitute a local ground-water-movement system, and the hydrogeologic units below Qc1 are part of a more regional ground-water system.

Water from 33 sites, which include 29 wells and 4 springs, was sampled and analyzed to determine the quality of ground water in the study area. All 33 samples were analyzed for nitrite plus nitrate, major ions, arsenic, iron, manganese, and bacteria, but only some of the samples were analyzed for trace elements, MBAS, boron, radon, pesticides, TOC, and VOCs. Other properties of the water ( $\mathrm{pH}$, temperature, specific conductance, alkalinity, and dissolved-oxygen content) were determined for all 33 samples.

The overall quality of ground water in the study area was good; only four constituents were found at concentrations above those allowed by drinking water standards or guidelines. Two of the four constituents, the pesticide dieldrin in water from one well and total-coliform bacteria in water from four wells or springs, were at levels exceeding standards or guidelines related to human health. Concentrations of iron or manganese in water from eight wells and springs exceeded the amount allowed by secondary drinking water standards, which are not health related. Concentrations of iron and manganese in ground water above secondary drinking water standards is fairly typical for the Puget Sound region. Concentrations of other trace elements met drinking water standards or guidelines.

\section{SELECTED REFERENCES}

AGI Technologies, 1998, Volume I, Report of 1995 ground water studies south Tacoma aquifer system: WHERE, AGI Technologies, Water Resources Group, 15,685.109, unpaginated.

Alhajjar, B.J., 1985, Groundwater contamination from septic systems receiving detergents of two types of formulation: Madison, Wisconsin, University of Wisconsin, Ph.D. thesis, 372 p.

American Public Health Association, 1971, Standard methods for the examination of water and wastewater (13th ed.): Washington, D.C., American Public Health Association, p. 303-304. 
1981, Standard methods for the examination of water and wastewater (15th ed.): Washington, D.C., American Public Health Association, p. 370-373.

1985, Standard methods for the examination of water and wastewater (16th ed.): Washington, D.C., American Public Health Association, p. 287-290, 394-396, and 400-402.

American Public Health Association, American Water Works Association, and Water Environment Federation, 1992, Standard methods for the examination of water and wastewater (18th ed.): Washington, D.C., American Public Health Association, p. 4.1-4.5.

Barbash, J.E., and Resek, E.A., 1996, Pesticides in ground water--distribution, trends, and governing factors: Chelsea, Michigan, Ann Arbor Press, Inc., 588 p.

Bauer, H.H., and Mastin, M.C., 1997, Recharge from precipitation in three small glacial-till-mantled catchments in the Puget Sound Lowland, Washington: U.S. Geological Survey WaterResources Investigations Report 96-4219, 119 p.

Bauer, H.H., and Vaccaro, J.J., 1987, Documentation of a model for estimating ground-water recharge: U.S. Geological Survey Open-File Report 86-536, 180 p.

Bear, Jacob, 1979, Hydraulics of ground water: New York, New York, McGraw-Hill, 569 p.

B.I. Larsen and Associates, 1963, Investigation of groundwater geology and pollution potential, vicinity of proposed Orchard Street sanitary landfill site extension: Seattle, Wash., B.I. Larsen and Associates, $10 \mathrm{p}$.

Black and Veatch, 1983, Preliminary field investigation, south Tacoma swamp, Tacoma, Washington: Tacoma, Wash., Black and Veatch, unpaginated.

1987a, Remedial investigation report, Tacoma landfill, Tacoma, Washington, volume 1: Tacoma, Wash., Black and Veatch, unpaginated.

1987b, Remedial investigation report, Tacoma landfill, Tacoma, Washington, volume 2: Tacoma, Wash., Black and Veatch, unpaginated.
Booth, D.B., 1987, Timing and processes of deglaciation along the southern margin of the Cordilleran ice sheet, in Ruddiman, W.F., and Wright, H.E., Jr., eds., The geology of North America: Geological Society of America, v. K-3, p. 71-90.

Bortleson, G.C., and Davis, D.A., 1997, Pesticides in selected small streams in the Puget Sound Basin, 1987-1995: U.S. Geological Survey Fact Sheet 067-97, 4 p.

Bretz, J.H., 1910, Glacial lakes of Puget Sound: Journal of Geology, v. 18 , no. 5 , p. $448-458$.

1911, The terminal moraine of the Puget Sound glacier: Journal of Geology, no. 19, p. 161-174.

1913, Glaciation of the Puget Sound region: Washington Geological Survey Bulletin no. 8, 244 p.

Brown and Caldwell, 1985, Clover/Chambers Creek geohydrologic study for Tacoma-Pierce County Health Department: Seattle, Wash., Brown and Caldwell, unpaginated.

Buchanan-Banks, J.M., and Collins, D.S., 1994, Map showing depth to bedrock of the Tacoma and part of the Centralia 30 ' by 60 ' quadrangles, Washington: U.S. Geological Survey Miscellaneous Field Studies Map MF-2265, 2 sheets, scale 1:100,000.

Carnahan, B., Luther, H.A., and Wilkes, J.O., 1969, Applied numerical methods: New York, N.Y., John Wiley and Sons, Inc., 604 p.

Carr and Associates, 1988, Report on the 1987-88 test drilling program: Gig Harbor, Wash., Carr and Associates, unpaginated.

CH2M Hill, 1984, Field investigation feasibility study, south Tacoma Channel, Washington (south Tacoma public well 12A): Seattle, Wash., CH2M Hill, unpaginated.

1991, South Tacoma aquifer recharge feasibility study: Seattle, Wash., CH2M Hill, unpaginated. 
Crandell, D.R., 1965, The glacial history of western Washington and Oregon, in Wright, H.E. Jr., and Frey, D.G., eds., The Quaternary of the United States: Princeton, N.J., Princeton University Press, p. 341-353.

Crandell, D.R., and Mullineaux, D.R., 1965, Age and origin of the Puget Sound trough in western Washington: U.S. Geological Survey Professional Paper 525-B, p. B132-B136.

Crandell, D.R., Mullineaux, D.R., and Waldron, H.H., 1958 , Pleistocene sequence in southeastern part of the Puget Sound Lowland, Washington: American Journal of Science, v. 256, p. 384-397.

Daly, C., Neilson, R.P., and Phillips, D.L., 1994, A statistical-topographic model for mapping climatological precipitation over mountainous terrain: Journal of Applied Meteorology, v. 33, p. 140-158.

Daly, M.H., and Lindsey, B.D., 1996, Occurrence and concentrations of volatile organic compounds in shallow ground water in the Lower Susquehanna River Basin, Pennsylvania and Maryland: U.S. Geological Survey Water-Resources Investigations Report 96-4141, 8 p.

Dinicola, R.S., 1990, Characterization and simulation of rainfall-runoff relations for headwater basins in western King and Snohomish Counties, Washington: U.S. Geological Survey Water-Resources Investigations Report 89-4052, 52 p.

Dion, N.P., and Lum, W.E., II, 1977, Municipal, industrial, and irrigation water use in Washington, 1975: U.S Geological Survey Open-File Report 77-308, 34 p.

Dion, N.P., and Sumioka, S.S., 1984, Seawater intrusion into coastal aquifers in Washington, 1978: U.S. Geological Survey Water-Supply Bulletin 56,13 p.

Dion, N.P., Turney, G.L., and Jones, M.A., 1994, Hydrology and quality of ground water in northern Thurston County, Washington: U.S. Geological Survey Water-Resources Investigations Report 92-4109, $188 \mathrm{p}$.
Dragovich, J.D., Pringle, P.T., and Walsh, T.J., 1994, Extent and geometry of the Mid-Holocene Osceola Mudflow in the Puget Lowland--implications for Holocene sedimentation and paleogeography: Washington State Department of Natural Resources, Washington Geology, v. 22, no. 3, p. 3-26.

Drewry, David, 1986, Glacial geologic processes: Baltimore, Maryland, Edward Arnold Publishers, $276 \mathrm{p}$.

Ebbert, J.C., Bortleson, G.C., Fuste, L.A., and Prych, E.A., 1987, Water quality in the lower Puyallup River Valley and adjacent uplands, Pierce, County, Washington: U.S. Geological Survey WaterResources Investigations Report 86-4154, 199 p.

Ebbert, J.C., Cox, S.E., Drost, B.W., and Schurr, K.M., 1995, Distribution and sources of nitrate, and presence of pesticides, in parts of the Pasco Basin, Washington, 1986-88: U.S. Geological Survey Water-Resources Investigations Report 93-4197, $173 \mathrm{p}$.

EMCON and Tacoma-Pierce County Health Department Staff, 1995, Clover-Chambers Creek Basin ground water management program implementation project--final report: Bothell, Wash., EMCON, unpaginated.

Emigh, Frank, 1963, Report on Mason Gulch: Tacoma Wash., Frank Emigh, 5 p. [Prepared for the city of Tacoma, contains information on the potable water capability of springs in Mason Gulch].

Environmental Services, 1995, Chambers-Clover Creek watershed management committee, preliminary draft, watershed action plan (phase 2): Tacoma, Wash., Environmental Services, 133 p.

Fenelon, J.M., and Moore, R.C., 1996, Occurrence of volatile organic compounds in ground water in the White River Basin, Indiana, 1994-95: U.S. Geological Survey Fact Sheet 138-96, 4 p.

Ferris, J.G., Knowles, D.B., Brown, R.H., and Stallman, R.W., 1962, Theory of aquifer tests: U.S. Geological Survey Water-Supply Paper 1536-E, 174 p. 
Fishman, M.J., and Friedman, L.C., eds., 1989, Methods for determination of inorganic substances in water and fluvial sediments: U.S. Geological Survey Techniques of Water-Resources Investigations, Book 5, chap. A1, 545 p.

Flint, R.F., 1971, Glacial and Quaternary geology: New York, N.Y., John Wiley and Sons, 892 p.

Foxworthy, B.L., and Richardson, Donald, 1973, Climatic factors related to land-use planning in the Puget Sound Basin, Washington: U.S. Geological Survey Miscellaneous Geologic Investigations Map I-851 A, 1 sheet, scale 1:1,000,000.

Freeze, R.A., and Cherry, J.A., 1979, Groundwater: Englewood Cliffs, N.J., Prentice-Hall, Inc., 604 p.

Geological Consulting Services, 1987, Puyallup hatchery water supply study: Bainbridge Island, Wash., Geological Consulting Services, 141 p.

Golder Associates Inc., 1990, Installation and development of well no. 2 for the proposed Clarks Creek fish hatchery, Puyallup, Washington: Redmond Wash., Golder Associates Inc., 14 p.

Gower, H.D., 1978, Tectonic map of the Puget Sound region, Washington, showing locations of faults, principal folds and large-scale Quaternary deformation: U.S. Geological Survey Open-File Report 78-426, 21 p.

Gower, H.D., Yount, J.C., and Crosson, R.S., 1985, Seismotectonic map of the Puget Sound region, Washington: U.S. Geological Survey Miscellaneous Investigations Series, Map I-1613, scale 1:250,000.

Griffin, W.C., Sceva, J.E., Swenson, H.A., and Mundorff, M.J., 1962, Water resources of the Tacoma area, Washington: U.S. Geological Survey Water-Supply Paper 1499-B, p. B1-B101.

Hall, J.B., and Othberg, K.L., 1974, Thickness of unconsolidated sediments, Puget Lowland, Washington: Washington Department of Natural Resources, Geologic Map GM-12, 1 plate, 3 p., scale $1: 250,000$.
Hansen, B.S., and Easterbrook, D.J., 1974, Stratigraphy and palynology of late Quaternary sediments in the Puget Lowland, Washington: Geological Society of America Bulletin, v. 85, no. 4, p. 587-602.

Hart Crowser and Associates Inc., 1986, Groundwater resource evaluation existing and new supply area, Tacoma, Washington: Seattle, Wash., Hart Crowser and Associates, Inc., J-1462-02, unpaginated.

Heath, R.C., 1983, Basic ground-water hydrology: U.S. Geological Survey Water-Supply Paper 2220, 84 p.

Hem, J.D., 1985, Study and interpretation of the chemical characteristics of natural water (3rd ed.): U.S. Geological Survey Water-Supply Paper 2254, 263 p.

Hirsch, R.M., Slack, J.R., and Smith, R.A., 1982, Techniques of trend analysis for monthly water quality data: Water Resources Research, v. 18, no. 1, p. 107-121.

Hitt, K.J., 1994, Refining 1970's land-use data with 1990 population data to indicate new residential development: U.S. Geological Survey WaterResources Investigations Report 94-4250, 17 p.

Hong West, 1995, Pierce County coordinated water system plan update: Lynnwood, Wash., Hong West, unpaginated.

Horowitz, A.J., Demas, C.R., Fitzgerald, K.F., Miller, T.L., and Rickert, D.A., 1994, U.S. Geological Survey protocol for the collection and processing of surface-water samples for the subsequent determination of inorganic constituents in filtered water: U.S. Geological Survey Open-File Report 94-539, $57 \mathrm{p}$.

Hubbert, M.K., 1940, The theory of ground-water motion: Journal of Geology, v. 48, no. 8, pt. 1, p. 785-944.

James, L.G., Erpenbeck, J.M., Bassett, D.L., and Middleton, J.E., 1988, Irrigation requirements for Washington estimates and methodology: Washington State University, Bulletin EB 1513, 37 p. 
Johnson, S.Y., Dadisman, S.V., Childs, J.R., Stanley, W.D., Buckman, R.C., and Haugerud, R.A., 1996, The Seattle fault is offset by two active dextral strike-slip faults in Puget Sound, Washington--implications for earthquake hazards: Geological Society of America, Abstracts with Programs, v. 28, p. A-416.

Jones, M.A., 1996, Thickness of unconsolidated deposits in the Puget Sound Lowland, Washington and British Columbia: U.S. Geological Survey WaterResources Investigations Report 94-4133, 1 pl., scale 1:500,000.

Kendall, Maurice, 1975, Rank correlation methods: London, Charles Griffin and Co., Ltd., 202 p.

Kolpin, D.W., Barbash, J.E., and Gilliom, R.J., 1998, Occurrence of pesticides in shallow groundwater of the United States--initial results from the National Water-Quality Assessment Program: Environmental Science and Technology, v. 32, no. 5, p. 558-566.

Korm, S.F., 1992, Natural denitrification in the saturated zone--a review: Water Resources Research, v. 28, no. 6, p. $1,657-1,668$.

LaRocque, G.A., Jr., and Piper, A.M., 1938, Ground water in the Tacoma area, Washington--progress report no. 2: U.S. Geological Survey Open-File Report, 70 p.

Lerner, D.N., 1990, Groundwater recharge in urban areas, in Hydrological processes and water management in urban areas, Proceedings of the Duisberg Symposium, April 1988: International Association of Hydrological Sciences pub. no. 198, p. 59-65.

Lindley, C.E., Stewart, J.T., and Sandstrom, M.W., 1996, Determination of low concentrations of acetochlor in water by automated solid-phase extraction and gas chromatography with mass-selective determination: Journal of Association of Official Analytical Chemists International, v. 79, p. 962-966.

Ludtke, A., and Woodworth, M., 1997, UGSG blind sample project--monitoring and evaluating laboratory analytical quality: U.S. Geological Survey Fact Sheet 136-97, 2 p.
Lum, W.E., and Turney, G.L., 1985, A preliminary evaluation of hydrology and water quality near the Tacoma landfill, Pierce County, Washington: U.S. Geological Survey Water-Resources Investigations Report 84-4351, 35 p.

Mastin, M.C., 1996, Surface-water hydrology and runoff simulations for three basins in Pierce County, Washington: U.S. Geological Survey WaterResources Investigations Report 95-4068, 148 p.

McConnell, J.B., Bortleson, G.C., and Innes, J.K., 1976, Reconnaissance data on lakes in Washington-volume 4: Washington Department of Ecology Water-Supply Bulletin 42, v. 4, 141 p.

Meister Publishing Company, 1994, Farm chemicals handbook '94: Willoughby, Phio, Meister Publishing, unpaginated.

Mueller, D.K., Hamilton, P.A., Helsel, D.R., Hitt, K.J., and Ruddy, B.C., 1995, Nutrients in ground water and surface water of the United States--an analysis of data through 1992: U.S. Geological Survey WaterResources Investigations Report 95-4031, 74 p.

Myers, D.N., and Wilde, F.D., 1997, National field manual for the collection of water-quality data: U.S. Geological Survey Techniques of Water-Resources Investigations, Book 9, unpaginated.

National Oceanic and Atmospheric Administration, 1982, Monthly normals of temperature, precipitation, and heating and cooling degree days, 1951-80: Climatography of the United States, no. 81 (Washington), $17 \mathrm{p}$.

1995, Climatological data, annual summary, Washington, 1995: Asheville, North Carolina, National Climatic Data Center, v. 99, no. 13, 25 p.

1996, Climatological data, annual summary, Washington, 1996: Asheville, North Carolina, National Climatic Data Center, v. 100, no. 13, 25 p.

Noble, J.B., 1990, Proposed revision of nomenclature for the stratigraphy of coastal Pierce County, Washington: Washington State Department of Natural Resources Open-File Report 90-4, 54 p. 
Nowel1, L.H., and Resek, E.A., 1994, Summary of national standards and guidelines for pesticides in water, bed sediment, and aquatic organisms and their application to water-quality assessments: U.S. Geological Survey Open-File Report 94-44, 115 p.

Phillips, E.L., 1960, Climate of Washington: U.S. Department of Commerce, Climatology of the United States, no. $60-45,27$ p.

Pierce County Public Works and Utilities Water Resources Division, 1996a, Chambers-Clover Creek Watershed Management Committee watershed action plan--final draft: Pierce County Public Works and Utilities Water Resources Division, unpaginated.

1996b, Chambers-Clover Creek Watershed Management Committee watershed characterization--final draft: Pierce County Public Works and Utilities Water Resources Division, unpaginated.

Piper, A.M., and LaRocque, G.A., Jr., 1938, Ground water in the Tacoma area, Washington--progress report no. 1: U.S. Geological Survey Open-File Report, 105 p.

Pringle, P.T., 1988, New data for large, Late Holocene debris flows in the Puyallup Basin, west of Mount Rainier, Washington: Northwest Science, v. 62, no. 2 , p. 83 , abstract.

Puget Sound Regional Council, 1997, 1996 population and households estimates by census tract: Seattle, Wash., Puget Sound Regional Council, from URL http://www.psrc.org/dwnld.htm, accessed June 16, 1997, Microsoft Excel version 5.0 format.

Radtke, D.B., and Wilde, F.D., eds., 1997, National field manual for the collection of water-quality data: U.S. Geological Survey, Book 9, chap. 6.6, 215 p.

Robinson and Noble, Inc., 1992a, 96th street test well for the city of Puyallup: Tacoma, Wash., Robinson and Noble, Inc., 14 p.

1992b, Firgrove Mutual, Inc., hydrogeologic study and well assessment: Tacoma, Wash., Robinson and Noble, Inc., $78 \mathrm{p}$.

1995, Water rights investigation for water cooperative of Pierce County: Tacoma, Wash., Robinson and Noble, Inc., $50 \mathrm{p}$.
Robinson, Roberts, and Associates, Inc., 1964, Hydrogeologic report, Mason Gulch, city of Tacoma: Tacoma, Wash., Robinson, Roberts, and Associates, $14 \mathrm{p}$.

Rogers, W.P., 1970, A geological and geophysical study of the central Puget Lowland: Seattle, Wash., University of Washington, Ph.D. thesis, $123 \mathrm{p}$.

Ryker, S.J., and Williamson, A.K., 1996, Pesticides in public supply wells of Washington State: U.S. Geological Survey Fact Sheet 122-96, 2 p.

Sapik, D.B., Bortleson, G.C., Drost, B.W., Jones, M.A., and Prych, E.A., 1988, Ground-water resources and simulation of flow in aquifers containing freshwater and seawater, Island County, Washington: U.S. Geological Survey Water-Resources Investigations Report $87-4182,67 \mathrm{p}$.

Sceva, J.E., Wegner, D.E., and others, 1955, Records of wells and springs, water levels, and quality of ground water in central Pierce County, Washington: U.S. Geological Survey Open-File Report, 261 p.

Schumann, R.R., 1993, Geologic radon potential of EPA Region 10: U.S. Geological Survey Open-File Report 93-292-J, 149 p.

Shamir, Uri, 1981, The south Tacoma aquifer as a supplementary water source: Vancouver, British Columbia, Shamir, 27 p.

Skougstad, M.W., Fishman, J.J., Friedman, L.C., Erdmann, D.E., and Duncan, S.S., eds., 1979, Methods for determination of inorganic substances in water and fluvial sediments: U.S. Geological Survey Techniques of Water-Resources Investigations, Book 5, chap. A1, 626 p.

Sugden, D.E., and John, B.S., 1976, Glaciers and landscape--a geomorphological approach: New York, N.Y., John Wiley and Sons, 376 p.

Sweet, Edwards, and Associates, Inc., 1986, Evaluation of recharge potential and existing facilities and sites--supplement to groundwater recharge proposal, south Tacoma channel: Seattle, Wash., Sweet, Edwards, and Associates, Inc., unpaginated. 
Tesoriero, A.J., and Voss, F.D., 1997, Predicting the probability of elevated nitrate concentrations in the Puget Sound Basin--implications for aquifer susceptibility and vulnerability: Ground Water, v. 35 , no. 6 , p. $1,029-1,039$.

Theis, C.V., 1963, Estimating the transmissivity of a water-table aquifer from the specific capacity of a well, in Bentall, Ray, compiler, Methods of determining permeability, transmissivity, and drawdown: U.S. Geological Survey Water-Supply Paper 1536-I, p. 332-336.

Thomas, B.E., Wilkinson, J.M., Embrey, S.S., 1997, The ground-water system and ground-water quality in western Snohomish County, Washington: U.S. Geological Survey Water-Resources Investigations Report 96-4312, 218 p.

Thornbury, W.D., 1969, Principles of geomorphology (2nd ed.): New York, N.Y., John Wiley and Sons, $594 \mathrm{p}$.

Thorson, R.M., 1980, Ice-sheet glaciation of the Puget lowland, Washington, during the Vashon stade (late Pleistocene): Quaternary Research, v. 13, p. 303-321.

1989, Glacio-isostatic response of the Puget Sound area, Washington: Geological Society of America Bulletin, v. 101, p. 1,163-1,174.

Todd, D.K., 1963, Ground-water hydrology: New York, N.Y., John Wiley and Sons, 336 p.

Turney, G.L., 1986, Quality of ground water in the Puget Sound region, Washington, 1981: U.S. Geological Survey Water-Resources Investigations Report 84-4258, 170 p.

Turney, G.L., Kahle, S.C., and Dion, N.P., 1995, Geohydrology and ground-water quality of east King County, Washington: U.S. Geological Survey Water-Resources Investigations Report 94-4082, $123 \mathrm{p}$.

U.S. Department of Agriculture, 1979, Soil survey of Pierce County area, Washington: U.S. Department of Agriculture, Soil Conservation Service, 131 p.
U.S. Environmental Protection Agency, 1975, Ground water monitoring, fiscal year 1975 , south TacomaLakewood area, Washington: Seattle, Wash., U.S. Environmental Protection Agency Region X, 16 .

1982, Commencement Bay remedial response fact sheet: Seattle, Wash., U.S. Environmental Protection Agency Region X, 41 p.

1984, Hydrological simulation program-FORTRAN (HSPF)--users manual for release 8.0: Environmental Research, EPA-600/3-84-066, 767 p.

1991, Test methods for Escherichia coli in drinking water: Cincinnati, Ohio, U.S. Environmental Protection Agency, Office of Water, EPA/600/491/016, about 12 p.

1993, Support document for sole source aquifer designation of the central Pierce County aquifer system: U.S. Environmental Protection Agency, Water Division, EPA-910/R93-001, 12 p.

1995, Lead and copper rule fact sheet: U.S. Environmental Protection Agency, Office of Water, EPA 570/9-91-400, January 1995, 2 p.

1996, Drinking water regulation and health advisories: Washington, D.C., U.S. Environmental Protection Agency, Office of Water, EPA 822-R-96-001, about 12 p.

U.S. Geological Survey, 1979, Land use and land cover, 1975, Tacoma, Washington: U.S. Geological Survey Land Use Series Map L-1, 1 sheet.

1983, Use of flumes in measuring discharge: U.S. Geological Survey Techniques of Water-Resources Investigations, Book 3, chap. A14, 46 p.

1985, Streamflow statistics and drainage basin characteristics for the Puget Sound region, Washington, v. I, for the Puget Sound region, Washington: U.S. Geological Survey Open-File Report 84-144-A, 330 p.

1996, Water resources data, Washington, water year 1996: U.S. Geological Survey Water-Data Report WA-96-1, 494 p. 
U.S. Soil Conservation Service, 1975, Livestock water use: U.S. Soil Conservation Service, $41 \mathrm{p}$.

U.S. Weather Bureau, 1965, Mean annual precipitation, 1930-1957, State of Washington: U.S. Department of Agriculture, Soil Conservation Service, Map M-4430, single sheet.

Veatch, F.M., Kimmel, G.E., and Johnston, E.A., 1966, Surface- and ground-water conditions during 1959-61 in a part of the Flett Creek Basin, Tacoma, Washington: U.S. Geological Survey Open-File Report, $42 \mathrm{p}$.

Walsh, T.J., compiler, 1987, Geologic map of the south half of the Tacoma quadrangle, Washington: Washington Division of Geology and Earth Resources Open-File Report 87-3, 10 p., 1 plt., scale 1:100,000.

Walsh, T.J., Korosec, M.A., Phillips, W.M., Logan, R.L., and Schasse, H.W., 1987, Geologic map of Washington--southwest quadrant: Washington Division of Geology and Earth Resources Geologic Map GM-34, 28 p., 2 sheets, scale 1:125,000.

Walters, K.L., 1971, Reconnaissance of sea-water intrusion along coastal Washington, 1966-1968: U.S. Geological Survey Water-Supply Bulletin no. 32,208 p.

Walters, K.L., and Kimmel, G.E., 1968, Ground-water occurrence and stratigraphy of unconsolidated deposits, central Pierce County, Washington: Washington State Department of Water Resources Water-Supply Bulletin no. 22, 428 p.

Washington Department of Ecology, 1979, Coastal zone atlas of Washington, v. 7, Pierce County: Washington Department of Ecology, DOE77-21-7, 8 p.

1990a, Minimum standards for construction and maintenance of water wells: Olympia, Wash., Washington Department of Ecology, chap. 173-160 WAC, October 19, 1991, p. 4.

$1990 \mathrm{~b}$, Streamflow and ground water level records for southwest Washington 1976 to 1989: Washington Department of Ecology, Open-File Report 90-57, $463 \mathrm{p}$.
1994, Guidelines and requirements for public water systems regarding water use reporting, demand forecasting methodology, and conservation programs: Washington Department of Ecology, Open-File Report 94-24, 26 p.

1995a, Draft initial watershed assessment water resources inventory, area 10, Puyallup-White watershed: Washington Department of Ecology, Open-File Report 95-08, 69 p.

1995b, Draft initial watershed assessment water resources inventory, area 12 , Chambers-Clover Creek watershed: Washington Department of Ecology, Open-File Report 95-09, 63 p.

Washington State Department of Social and Health Services, 1978: Rules and regulations of the State Board of Health regarding public water systems: Olympia, Wash., Health Services Division, Water Supply and Waste Section, 48 p.

1981, Survey of groundwater and surface water quality for the Chambers Creek/Clover Creek drainage basin, Pierce County: Olympia, Wash., Health Services Division, Water Supply and Waste Section, $102 \mathrm{p}$.

Werner, S.L., Burkhart, M.R., and DeRusseau, S.N., 1996, Methods of analysis by the U.S. Geological Survey National Water Quality Laboratory--determination of pesticides in water by Carbopack-B solid-phase extraction and high-performance liquid chromatography: U.S. Geological Survey Open-File Report 96-216, 42 p.

Wershaw, R.L, Fishman, M.J., Grabbe, R.R., and Lowe, L.E., eds., 1987, Methods for the determination of organic substances in water and fluvial sediments: U.S. Geological Survey Techniques of WaterResources Investigations, Book 5, chap. A3, 80 p.

White, A.F., Peterson, M.L., and Solbau, R.D., 1990, Measurement and interpretation of low levels of dissolved oxygen in ground water: Ground Water, v. 28 , no. 4 , p. $584-590$.

Wood, W.W., 1981, Guidelines for collection and field analysis of ground-water samples for selected unstable constituents: U.S. Geological Survey Techniques of Water-Resources Investigations, Book 1, chap. D2, 24 p. 
Woodward, D.G., Packard, F.A., Dion, N.P., and Sumioka, S.S., 1995, Occurrence and quality of ground water in southwestern King County, Washington: U.S. Geological Survey Water-Resources Investigations Report 92-4098, 69 p.

Zaugg, S.D., Sandstrom, M.W., Smith, S.G., and Fehlberg, K.M., 1995, Methods of analysis by the U.S. Geological Survey National Water Quality Laboratory--determination of pesticides in water by $\mathrm{C}-18$ solid phase extraction and capillary-column gas chromatography/mass spectrometry with selected-ion monitoring: U.S. Geological Survey Open-File Report 95-181, 60 p. 
Table 15.--Altitude of top of hydrogeologic units in wells in the Tacoma-Puyallup area, Washington

\section{EXPLANATION}

[NP, unit not present; --, well does not penetrate to stratigraphic position where unit may or may not be present; 0, sea level (NGVD of 1929); ?, log incomplete at surface]

Latitude and Longitude:

$\overline{8}$

Land surface altitude:

Hole depth:
Most well locations are believed to be accurate to within 1 second of latitude and longitude. The least accurate locations are probably within 10 seconds of latitude and longitude.

Most altitudes were assigned from topographic maps (1:24,000 with 10- or 20-foot contour intervals) and are generally accurate to within 10 feet. In steep terrain, or where the precise location of the well is in doubt, the error may be as great as 50 feet. Some wells ( $<10$ percent) have been surveyed and are accurate to within 1 foot.

Total depth penetrated during drilling; does not necessarily equal finished depth of well. 
Table 15.--Altitude of top of hydrogeologic units in wells in the Tacoma-Puyallup area, Washington--Continued

\begin{tabular}{|c|c|c|c|c|c|c|c|c|c|c|c|c|c|c|}
\hline \multirow{2}{*}{$\begin{array}{l}\text { Local well } \\
\text { number }\end{array}$} & \multirow[b]{2}{*}{ Latitude } & \multirow[b]{2}{*}{ Longitude } & \multirow{2}{*}{$\begin{array}{l}\text { Land } \\
\text { surface } \\
\text { altitude } \\
\text { (feet) }\end{array}$} & \multirow{2}{*}{$\begin{array}{l}\text { Hole } \\
\text { depth } \\
\text { (feet) }\end{array}$} & \multicolumn{10}{|c|}{ Altitude of top of hydrogeologic unit, in feet } \\
\hline & & & & & Qvr & Qvt & Qcl & Qfl & Qc2 & Qf2 & Qc3 & Qf3 & Qc4 & Qf4 \\
\hline 19N/03E-01A01 & 471007 & 1222136 & 460 & 303 & NP & 460 & 423 & 270 & 245 & -- & -- & -- & -- & -- \\
\hline 19N/03E-01C01 & 471009 & 1222201 & 430 & 190 & $\mathrm{NP}$ & 430 & 401 & 270 & 255 & -- & -- & -- & -- & -- \\
\hline $19 \mathrm{~N} / 03 \mathrm{E}-01 \mathrm{C} 02$ & 470959 & 1222200 & 445 & 195 & NP & 445 & 384 & 286 & 264 & -- & -- & -- & -- & -- \\
\hline 19N/03E-01E01 & 470958 & 1222230 & 473.8 & 285 & NP & 474 & 311 & 297 & 218 & -- & -- & -- & -- & -. \\
\hline $19 \mathrm{~N} / 03 \mathrm{E}-01 \mathrm{G} 02$ & 470944 & 1222146 & 450 & 619 & NP & 450 & 310 & 286 & 233 & 215 & NP & 100 & -- & -- \\
\hline 19N/03E-01J01 & 470941 & 1222137 & 475 & 407 & $\mathrm{NP}$ & 475 & 311 & 308 & 274 & 247 & 125 & 113 & -- & -- \\
\hline 19N/03E-03B01 & 471000 & 1222420 & 430 & 316 & NP & 430 & 239 & 209 & 182 & 131 & - & -- & -- & -- \\
\hline 19N/03E-03B02 & 471010 & 1222421 & 425 & 839 & NP & 425 & 229 & 172 & 148 & 122 & 85 & 7 & -192 & \\
\hline $19 \mathrm{~N} / 03 \mathrm{E}-03 \mathrm{~F} 02$ & 470949 & 1222445 & 405 & 387 & NP & 405 & 249 & 211 & NP & 160 & 91 & 31 & -- & -- \\
\hline $19 \mathrm{~N} / 03 \mathrm{E}-03 \mathrm{~F} 04$ & 470951 & 1222447 & 405 & 371 & NP & 405 & 235 & 205 & NP & 160 & 85 & -- & -- & - \\
\hline 19N/03E-03G01 & 470959 & 1222420 & 430 & 415 & $\mathrm{NP}$ & 430 & 235 & 210 & 144 & 140 & 118 & -- & -- & -- \\
\hline $19 \mathrm{~N} / 03 \mathrm{E}-03 \mathrm{G} 02$ & 470955 & 1222423 & 430 & 422 & NP & 430 & 245 & 227 & 169 & 154 & 70 & 11 & -- & -- \\
\hline 19N/03E-11G03 & 470852 & 1222306 & 420 & 254 & NP & 420 & 247 & 245 & 202 & -- & -- & -- & -- & -- \\
\hline 19N/03E-11Q01 & 470833 & 1222302 & 415 & 242 & NP & 415 & 355 & 265 & 178 & -- & - & -- & -- & -- \\
\hline 19N/03E-13R01 & 470733 & 1222127 & 455 & 161 & NP & 455 & 297 & -- & -- & -- & -- & -- & -- & -- \\
\hline $19 \mathrm{~N} / 03 \mathrm{E}-25 \mathrm{C} 01$ & 470629 & 1222212 & 350 & 51 & 350 & 348 & -- & -- & -- & -- & -- & -- & -- & -- \\
\hline 19N/04E-01A01 & 471006 & 1221344 & 90 & 96 & NP & NP & 90 & NP & 0 & -- & -- & -- & -- & -- \\
\hline 19N/04E-01H01 & 470949 & 1221344 & 95 & 197 & NP & NP & NP & 95 & 25 & -- & -- & -- & - & -- \\
\hline 19N/04E-01Q01 & 470925 & 1221403 & 110 & 104 & NP & NP & NP & 110 & 16 & -- & -- & -- & -- & -- \\
\hline 19N/04E-02F01 & 470955 & 1221542 & 410 & 624 & 410 & 342 & 227 & 174 & 31 & 1 & -125 & -- & -- & -- \\
\hline 19N/04E-02J01 & 470931 & 1221500 & 500 & 425 & NP & 500 & NP & 279 & 77 & -- & -- & -- & -- & -- \\
\hline 19N/04E-03A01D1 & 471008 & 1221628 & 445 & 847 & 445 & 428 & 265 & 263 & 104 & 35 & -20 & -95 & -275 & -311 \\
\hline 19N/04E-03K02 & 470938 & 1221650 & 460 & 34 & 460 & -- & -- & -- & -- & -- & -- & -- & -- & -- \\
\hline 19N/04E-03K03 & 470937 & 1221648 & 460 & 45 & 460 & -- & -- & -- & -- & -- & -- & -- & -- & -- \\
\hline 19N/04E-03K04 & 470939 & 1221651 & 450 & 37 & 450 & -- & -- & - & -- & -- & -- & -- & -- & -- \\
\hline 19N/04E-03Q01 & 470930 & 1221637 & 500 & 44.5 & NP & 500 & -- & -- & -- & -- & -- & -- & -- & -- \\
\hline 19N/04E-03R01D2 & 470919 & 1221632 & 530 & 810 & NP & 530 & 403 & 288 & 114 & 94 & -22 & -82 & -192 & -221 \\
\hline 19N/04E-04L01 & 470935 & 1221819 & 355 & 240 & 355 & 313 & 175 & 169 & 149 & & -- & -- & -- & -- \\
\hline 19N/04E-04L02 & 470934 & 1221819 & 355 & 264 & 355 & 313 & 206 & 190 & 135 & 91 & - & -- & - & -- \\
\hline 19N/04E-04Q01 & 470928 & 1221805 & 410 & 327 & 410 & 393 & NP & 250 & 146 & -. & -- & -- & -- & -- \\
\hline 19N/04E-05P02 & 470922 & 1221945 & 435 & 258 & NP & 435 & 299 & 273 & 240 & -- & -- & -- & -- & -- \\
\hline 19N/04E-06J02 & 470934 & 1222011 & 440 & 207 & NP & 440 & 370 & 340 & 257 & -- & -- & -- & -- & -- \\
\hline 19N/04E-07A01 & 470911 & 1222010 & 415 & 36.6 & NP & 415 & -- & -- & -- & -- & -- & -- & - & -- \\
\hline 19N/04E-07D01 & 470912 & 1222105 & 450 & 326 & NP & 450 & NP & 325 & 259 & 184 & -- & -- & - & -- \\
\hline
\end{tabular}


Table 15.--Altitude of top of hydrogeologic units in wells in the Tacoma-Puyallup area, Washington--Continued

\begin{tabular}{|c|c|c|c|c|c|c|c|c|c|c|c|c|c|c|}
\hline \multirow{2}{*}{$\begin{array}{l}\text { Local well } \\
\text { number }\end{array}$} & \multirow[b]{2}{*}{ Latitude } & \multirow[b]{2}{*}{ Longitude } & \multirow{2}{*}{$\begin{array}{l}\text { Land } \\
\text { surface } \\
\text { altitude } \\
\text { (feet) }\end{array}$} & \multirow{2}{*}{$\begin{array}{l}\text { Hole } \\
\text { depth } \\
\text { (feet) }\end{array}$} & \multicolumn{10}{|c|}{ Altitude of top of hydrogeologic unit, in feet } \\
\hline & & & & & Qvr & Qvt & Qcl & Qfl & Qc2 & Qf2 & Qc3 & Qf3 & Qc4 & Qf4 \\
\hline 19N/04E-07D02 & 470912 & 1222103 & 450 & 275 & NP & 450 & NP & 319 & 249 & 229 & -- & -- & -- & -- \\
\hline 19N/04E-07F01D1 & 470901 & 1222057 & 460 & 604 & NP & 460 & 233 & 217 & 181 & 156 & 2 & -71 & -131 & -- \\
\hline 19N/04E-07F02 & 470900 & 1222100 & 455 & 257 & NP & 455 & 233 & 216 & -- & -- & -- & -- & -- & -. \\
\hline 19N/04E-07N01 & 470826 & 1222118 & 475 & 12.9 & NP & 475 & -- & -- & - & - & -- & -- & -- & -- \\
\hline 19N/04E-08A01 & 470911 & 1221859 & 346.29 & 304 & 346 & 300 & 290 & 146 & 118 & -. & -- & -- & -- & -- \\
\hline 19N/04E-08A06 & 470909 & 1221851 & 366.5 & 353.3 & 366.5 & 299.5 & 291.5 & 126.5 & 91.5 & 15.5 & -- & -- & -- & -- \\
\hline 19N/04E-08D01 & 470913 & 1221958 & 420 & 258 & NP & 420 & 241 & 232 & 184 & -- & -. & -- & -- & -- \\
\hline 19N/04E-08K01 & 470849 & 1221915 & 440 & 341.5 & NP & 440 & NP & 340 & 155 & 105 & -- & -- & -- & -. \\
\hline 19N/04E-09B01 & 470914 & 1221808 & 410 & 324 & $?$ & $?$ & $?$ & $?$ & 72 & -- & -- & -- & - & -. \\
\hline 19N/04E-09B02 & 470914 & 1221807 & 410 & 316 & $?$ & $?$ & $?$ & $?$ & 80 & -- & -- & -- & -- & -- \\
\hline 19N/04E-09B03 & 470914 & 1221808 & 410 & 363 & 410 & 386 & 378 & 129 & 123 & -- & -- & -- & -- & -. \\
\hline $19 \mathrm{~N} / 04 \mathrm{E}-10 \mathrm{~A} 01$ & 470905 & 1221619 & 570 & 271 & NP & 570 & 335 & -- & -- & -- & -- & $\ldots$ & -- & -- \\
\hline 19N/04E-11D01 & 470903 & 1221600 & 450 & 119.5 & 450 & 398 & 355 & -- & -- & -- & -. & -- & - & -- \\
\hline $19 \mathrm{~N} / 04 \mathrm{E}-11 \mathrm{D} 02$ & 470905 & 1221613 & 560 & 280 & NP & 560 & 302 & -- & -- & -- & -- & -- & -- & -- \\
\hline $19 \mathrm{~N} / 04 \mathrm{E}-12 \mathrm{~A} 02$ & 470911 & 1221342 & 110 & 76 & NP & $\mathrm{NP}$ & NP & 110 & 55 & -- & -- & -- & -. & -- \\
\hline 19N/04E-12B01 & 470906 & 1221404 & 110 & 54 & NP & NP & 110 & 84 & 58 & -- & -. & -- & -- & -- \\
\hline $19 \mathrm{~N} / 04 \mathrm{E}-12 \mathrm{H} 02$ & 470902 & 1221358 & 110 & 140.5 & NP & NP & NP & 110 & 34 & -. & -- & -- & -. & -- \\
\hline $19 \mathrm{~N} / 04 \mathrm{E}-12 \mathrm{H} 03$ & 470859 & 1221355 & 110 & 124 & NP & NP & NP & 110 & 30 & -- & -- & -- & -- & -- \\
\hline 19N/04E-12J02 & 470845 & 1221353 & 110 & 125 & NP & NP & NP & 110 & -13 & -- & -- & -- & -. & -. \\
\hline 19N/04E-12R02 & 470825 & 1221345 & 120 & 77 & NP & NP & NP & 120 & 47 & -- & -- & -- & -. & -- \\
\hline 19N/04E-13B01 & 470818 & 1221412 & 120 & 117 & NP & NP & NP & 120 & 38 & -- & -- & -- & -- & -- \\
\hline 19N/04E-13G01 & 470802 & 1221401 & 115 & 80 & NP & NP & 115 & 65 & 45 & -- & -- & -- & -- & -. \\
\hline 19N/04E-13K02 & 470755 & 1221406 & 120 & 14 & NP & $\mathrm{NP}$ & 120 & -- & -- & -- & -- & -- & -- & -- \\
\hline 19N/04E-14P01 & 470742 & 1221550 & 550 & 22 & 550 & 530 & - & -- & -- & -- & -- & -- & -- & -- \\
\hline 19N/04E-15F01 & 470801 & 1221700 & 510 & 71 & $\mathrm{NP}$ & 510 & 443 & -- & -- & -- & -- & -. & -- & -. \\
\hline $19 \mathrm{~N} / 04 \mathrm{E}-16 \mathrm{E} 01$ & 470800 & 1221842 & 450 & 305 & NP & 450 & NP & 413 & 165 & -- & -- & -- & -. & -- \\
\hline $19 \mathrm{~N} / 04 \mathrm{E}-16 \mathrm{E} 02 \mathrm{D} 2$ & 470805 & 1221843 & 450 & 440 & NP & 450 & NP & 371 & 169 & 119 & 65 & -- & -- & $\therefore$ \\
\hline $19 \mathrm{~N} / 04 \mathrm{E}-16 \mathrm{G} 03$ & 470806 & 1221757 & 460 & 400 & NP & 460 & 432 & 135 & 125 & -- & -- & -- & -- & -- \\
\hline 19N/04E-17K01 & 470752 & 1221910 & 480 & 374 & NP & 480 & NP & 398 & 212 & 197 & 135 & -- & -- & - \\
\hline 19N/04E-17N01 & 470737 & 1222001 & 355 & 170 & NP & 355 & 283 & 193 & -- & -- & -- & -- & -- & -- \\
\hline 19N/04E-19A01D1 & 470731 & 1222017 & 485 & 210 & NP & 485 & -- & -- & -- & -- & -- & -- & -- & -- \\
\hline 19N/04E-19D01 & 470730 & 1222120 & 445 & 9.7 & NP & 445 & -- & -- & -- & -- & -- & - & -- & -- \\
\hline 19N/04E-19N01 & 470642 & 1222115 & 410 & 90 & 410 & 403 & -- & -- & - & - & -- & -- & -- & -- \\
\hline $19 \mathrm{~N} / 04 \mathrm{E}-20 \mathrm{~F} 02$ & 470719 & 1221932 & 395 & 139.5 & 395 & 316 & 276 & -- & -- & -. & -- & -- & -- & - \\
\hline
\end{tabular}


Table 15.--Altitude of top of hydrogeologic units in wells in the Tacoma-Puyallup area, Washington--Continued

\begin{tabular}{|c|c|c|c|c|c|c|c|c|c|c|c|c|c|c|}
\hline \multirow{2}{*}{$\begin{array}{l}\text { Local well } \\
\text { number }\end{array}$} & \multirow[b]{2}{*}{ Latitude } & \multirow[b]{2}{*}{ Longitude } & \multirow{2}{*}{$\begin{array}{l}\text { Land } \\
\text { surface } \\
\text { altitude } \\
\text { (feet) }\end{array}$} & \multirow{2}{*}{$\begin{array}{l}\text { Hole } \\
\text { depth } \\
\text { (feet) }\end{array}$} & \multicolumn{10}{|c|}{ Altitude of top of hydrogeologic unit, in feet } \\
\hline & & & & & Qvr & Qvt & Qcl & Qfl & $\mathrm{Qc2}$ & Qf2 & Qc3 & Qf3 & Qc4 & Qf4 \\
\hline 19N/04E-20K03 & 470705 & 1221921 & 465 & 195.5 & NP & 465 & 275 & -- & -- & -- & -- & -- & -- & -- \\
\hline 19N/04E-20M01 & 470705 & 1221957 & 355 & 124 & 355 & 339 & 276 & -- & -- & -- & $\cdots$ & -- & -- & -- \\
\hline 19N/04E-20Q01D1 & 470651 & 1221925 & 400 & 325 & NP & 400 & 300 & 253 & 158 & 153 & 85 & - & - & - \\
\hline 19N/04E-20R04 & 470646 & 1221905 & 460 & 246 & NP & 460 & 312 & 296 & 222 & -- & - & -- & -- & -- \\
\hline 19N/04E-20R05 & 470646 & 1221905 & 465 & 261 & NP & 465 & 309 & 298 & 260 & -- & -- & -- & -- & -- \\
\hline 19N/04E-21D01 & 470730 & 1221835 & 450 & 231 & $\mathrm{NP}$ & 450 & NP & 335 & 243 & -- & -- & - & -- & -- \\
\hline 19N/04E-21K01 & 470705 & 1221752 & 480 & 11.3 & 480 & -- & -- & -- & -- & - & - & -- & -- & -- \\
\hline 19N/04E-22D01 & 470732 & 1221722 & 465 & 243 & 465 & NP & 405 & 285 & 235 & -- & -- & -- & -- & -- \\
\hline 19N/04E-22D02 & 470731 & 1221722 & 465 & 463 & 465 & 411 & 386 & 268 & 217 & 169 & -- & -- & -- & -- \\
\hline $19 \mathrm{~N} / 04 \mathrm{E}-25 \mathrm{~K} 02$ & 470610 & 1221408 & 155 & 97 & NP & NP & $\mathrm{NP}$ & 155 & 81 & - & -- & -- &.- & -- \\
\hline $19 \mathrm{~N} / 04 \mathrm{E}-26 \mathrm{C} 01$ & 470627 & 1221555 & 585 & 350 & 585 & 551 & 386 & 371 & 345 & 269 & -- & - & -- & -- \\
\hline 19N/04E-26G01 & 470617 & 1221520 & 605 & 370 & 605 & 597 & 415 & 405 & 328 & 236 & -- & -- & -- & -- \\
\hline 19N/04E-27A01 & 470629 & 1221630 & 585 & 225 & 585 & 555 & 387 & 363 & -- & -- & -- & -- & -- & -- \\
\hline 19N/04E-27B01 & 470634 & 1221647 & 570 & 9 & 570 & 562 & -- & -- & -- & -- & -- & -- & -- & -- \\
\hline 19N/04E-27N01 & 470556 & 1221725 & 530 & 354 & NP & 530 & 509 & 412 & 230 & -- & -- & -- & -- & -- \\
\hline 19N/04E-28B01 & 470638 & 1221752 & 510 & 697 & 510 & 501 & 415 & 351 & 205 & 98 & -79 & -171 & -- & -- \\
\hline 19N/04E-29D02 & 470629 & 1221949 & 360 & 91 & 360 & 346 & 287 & -- & -- & -- & -- & -- & -- & -- \\
\hline 19N/04E-29D06 & 470638 & 1221949 & 340 & 152 & 340 & NP & 270 & 201 & -- & - & -- & -- & -- & -- \\
\hline 19N/04E-29E02 & 470622 & 1221958 & 350 & 76 & 350 & 348 & 283 & - & -- & -- & -- & - & -- & -- \\
\hline 19N/04E-29E10D1 & 470619 & 1221956 & 400 & 79 & 400 & 398 & 346 & 326 & -- & -- & -- & -- & -- & -- \\
\hline 19N/04E-29J01 & 470609 & 1221855 & 510 & 199 & 510 & 492 & 380 & - & -- & -- & -- & -- & -- & $\sim$ \\
\hline $19 \mathrm{~N} / 04 \mathrm{E}-29 \mathrm{~K} 02$ & 470612 & 1221918 & 485 & 180 & NP & 485 & 342 & -- & -- & -- & -- & -- & -- & -- \\
\hline 19N/04E-29L03 & 470609 & 1221940 & 490 & 202 & 490 & 481 & 332 & -- & - & -- & - &.- & - & -- \\
\hline 19N/04E-29M02 & 470606 & 1221957 & 470 & 160 & 470 & 456 & 435 & -- & -- & -- & -- & -- & -- & -- \\
\hline 19N/04E-29R03 & 470551 & 1221905 & 490 & 149 & NP & 490 & 350 & -- & -- & -- & -- & -- & -- & -- \\
\hline 19N/04E-30A02 & 470626 & 1222017 & 380 & 80 & 380 & 377 & 310 & -- & -- & -- & -- & - & -- & -- \\
\hline 19N/04E-30A03 & 470628 & 1222009 & 355 & 40 & 355 & 354 & 325 & -- & -- & -- & -- & -- & -- & -- \\
\hline 19N/04E-30D03 & 470633 & 1222119 & 385 & 83 & 385 & 378 & 309 & -- & -- & -- & -- & -- & - & -- \\
\hline 19N/04E-30F03 & 470616 & 1222046 & 340 & 118 & 340 & 313 & 250 & -- & -- & -- & - & -- & -- & -. \\
\hline 19N/04E-30Q03 & 470552 & 1222030 & 465 & 160 & NP & 465 & 347 & -- & -- & -- & - & -- & -- & - \\
\hline $19 \mathrm{~N} / 04 \mathrm{E}-31 \mathrm{C} 03$ & 470545 & 1222100 & 460 & 140 & NP & 460 & 323 & -- & -- & -- & -- & -- & -- & -- \\
\hline 19N/05E-06A01 & 470958 & 1221232 & 90 & 97 & NP & NP & NP & 90 & -1 & -- & -- & -- & - & -. \\
\hline $19 \mathrm{~N} / 05 \mathrm{E}-06 \mathrm{C} 02$ & 471010 & 1221317 & 85 & 300 & NP & NP & NP & 85 & 5 & -92 & -161 & -- & -- & -- \\
\hline $19 \mathrm{~N} / 05 \mathrm{E}-06 \mathrm{E} 01$ & 470950 & 1221329 & 95 & 143 & NP & NP & NP & 95 & 27 & -- & -- & -- & -- & -- \\
\hline
\end{tabular}


Table 15.--Altitude of top of hydrogeologic units in wells in the Tacoma-Puyallup area, Washington--Continued

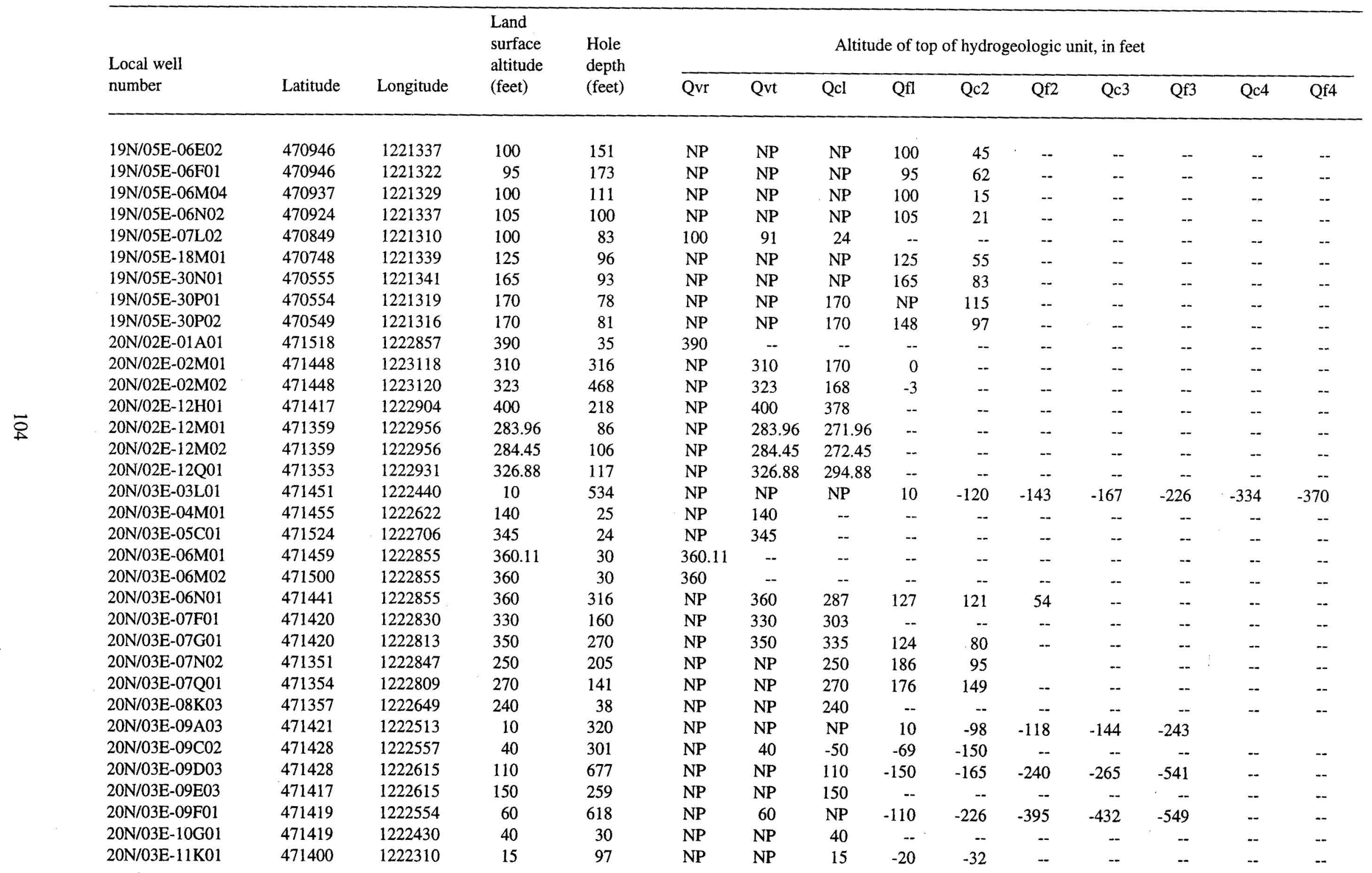


Table 15.--Altitude of top of hydrogeologic units in wells in the Tacoma-Puyallup area, Washington--Continued

\begin{tabular}{|c|c|c|c|c|c|c|c|c|c|c|c|c|c|c|}
\hline \multirow{2}{*}{$\begin{array}{l}\text { Local well } \\
\text { number }\end{array}$} & \multirow[b]{2}{*}{ Latitude } & \multirow[b]{2}{*}{ Longitude } & \multirow{2}{*}{$\begin{array}{l}\text { Land } \\
\text { surface } \\
\text { altitude } \\
\text { (feet) }\end{array}$} & \multirow{2}{*}{$\begin{array}{l}\text { Hole } \\
\text { depth } \\
\text { (feet) }\end{array}$} & \multicolumn{10}{|c|}{ Altitude of top of hydrogeologic unit, in feet } \\
\hline & & & & & Qvr & Qvt & Qcl & Qfl & Qc2 & Qf2 & Qc3 & Qf3 & Qc4 & Qf4 \\
\hline 20N/03E-11P02 & 471343 & 1222327 & 25 & 41 & NP & NP & NP & 25 & -13 & -- & -- & -- & -- & -- \\
\hline 20N/03E-11P04 & 471341 & 1222322 & 25 & 90 & NP & NP & NP & 25 & -20 & -- & -- & -- & -- & -- \\
\hline 20N/03E-11P05 & 471343 & 1222329 & 35 & 25 & NP & NP & 35 & -- & -- & -- & -- & -- & - & -- \\
\hline 20N/03E-11Q02 & 471351 & 1222309 & 10 & 316 & NP & NP & NP & 10 & -17 & -51 & -132 & -287 & -304 & -- \\
\hline $20 \mathrm{~N} / 03 \mathrm{E}-11 \mathrm{Q} 03$ & 471349 & 1222305 & 30 & 491 & NP & NP & NP & 30 & 0 & -69 & -147 & -242 & -282 & -- \\
\hline $20 \mathrm{~N} / 03 \mathrm{E}-13 \mathrm{C} 02$ & 471337 & 1222215 & 12 & 154 & NP & NP & 12 & -11 & -61 & -- & -- & -- & -- & -- \\
\hline $20 \mathrm{~N} / 03 \mathrm{E}-13 \mathrm{D} 02$ & 471329 & $1222219^{\circ}$ & 10 & 105 & NP & NP & NP & 10 & -50 & -- & -- & -- & -- & -- \\
\hline 20N/03E-13H05 & 471321 & 1222137 & 20 & 78 & NP & NP & 20 & 7 & -51 & -- & -- & -- & -- & -- \\
\hline $20 \mathrm{~N} / 03 \mathrm{E}-14 \mathrm{~A} 02$ & 471339 & 1222248 & 18 & 24.4 & NP & $\mathrm{NP}$ & NP & 18 & -4 & -- & -- & -- & -- & -- \\
\hline 20N/03E-14B01 & 471330 & 1222303 & 185 & 145 & NP & 185 & 122 & 51 & -- & -- & -- & -- & -- & -- \\
\hline $20 \mathrm{~N} / 03 \mathrm{E}-14 \mathrm{C} 02$ & 471340 & 1222329 & 20 & 38 & NP & $\mathrm{NP}$ & $\mathrm{NP}$ & 20 & -14 & -- & -- & -- & -- & -- \\
\hline 20N/03E-14F01 & 471322 & 1222328 & 200 & 133 & 200 & 195 & 75 & -- & -- & -- & $\ldots$ & -- & -- & -- \\
\hline $20 \mathrm{~N} / 03 \mathrm{E}-14 \mathrm{G} 01$ & 471325 & 1222255 & 100 & 77 & NP & 100 & 32 & -- & -- & -- & -- & -- & -- & -- \\
\hline 20N/03E-14R01 & 471258 & 1222239 & 250 & 231 & 250 & 222 & 192 & 150 & 74 & 24 & -- & -. & -- & -- \\
\hline 20N/03E-15F01 & 471326 & 1222434 & 247.5 & 698 & 247.5 & 189.5 & NP & 42.5 & -192.5 & -264.5 & -293.5 & -344.5 & -370.5 & -397.5 \\
\hline $20 \mathrm{~N} / 03 \mathrm{E}-17 \mathrm{G} 01$ & 471325 & 1222656 & 370 & 55 & NP & 370 & -- & -- & -- & -- & -- & -- & -- & -- \\
\hline 20N/03E-20K01 & 471222 & 1222702 & 350 & 17.5 & NP & 350 & -- & -- & -- & -- & -- & -- & -- & -- \\
\hline $20 \mathrm{~N} / 03 \mathrm{E}-20 \mathrm{P01}$ & 471159 & 1222714 & 315 & 299.4 & NP & 315 & 224 & -- & -- & -- & -- & -- & -- & -- \\
\hline 20N/03E-20P02 & 471159 & 1222714 & 315 & 299.4 & NP & 315 & 224 & 111 & 71 & -- & -- & -- & -- & -- \\
\hline $20 \mathrm{~N} / 03 \mathrm{E}-21 \mathrm{C} 01$ & 471241 & 1222553 & 355 & 238 & NP & 355 & 253 & 178 & 137 & -- & -- & -- & -- & - \\
\hline 20N/03E-22B01 & 471238 & 1222421 & 320 & -- & -- & -- & -- & -- & -- & -- & -- & -- & -- & -- \\
\hline 20N/03E-23H01 & 471227 & 1222251 & 380 & 256 & NP & 380 & 206 & 157 & 147 & -- & -- & -- & -- & -- \\
\hline 20N/03E-24A01 & 471238 & 1222135 & 25 & 70 & NP & $\mathrm{NP}$ & 25 & -35 & -- & -- & - & -- & -- & -- \\
\hline $20 \mathrm{~N} / 03 \mathrm{E}-25 \mathrm{C} 01$ & 471144 & 1222218 & 360 & 227 & NP & 360 & 202 & 195 & 173 & -- & -- &.- & -- & -- \\
\hline $20 \mathrm{~N} / 03 \mathrm{E}-25 \mathrm{CO} 2$ & 471145 & 1222218 & 360 & 305 & NP & 360 & 230 & 200 & 172 & 107 & 74 & -- & -- & -- \\
\hline 20N/03E-26K01 & 471128 & 1222315 & 410 & 27.5 & NP & 410 & -- & -- & - & -- & -- & -- & -- & -- \\
\hline 20N/03E-28F02 & 471131 & 1222556 & 400 & 36.5 & NP & 400 & -- & -- & -- & -- & -- & - & -- & -- \\
\hline $20 \mathrm{~N} / 03 \mathrm{E}-28 \mathrm{~J} 01$ & 471133 & 1222508 & 420 & 35 & NP & 420 & -- & -- & -- & -- & -- & -- & -- & -- \\
\hline 20N/03E-30R01 & 471107 & 1222802 & 300 & 30 & 300 & 280 & -- & -- & -- & -- & -- & -- & -- & -- \\
\hline 20N/03E-31A01 & 471055 & 1222756 & 300 & 18 & 300 & 286 & -- & -- & -- & -- & -- & -- & -- & -- \\
\hline 20N/03E-32D01 & 471053 & 1222738 & 300 & 15.7 & 300 & 287 & -. & -- & -- & -- & -- & -- & -- & -- \\
\hline 20N/03E-32D04 & 471103 & 1222738 & 300 & 114 & NP & 300 & 260 & - & -- & -- & -- & - & -- & -- \\
\hline 20N/03E-34E01 & 471049 & 1222453 & 415 & 19.8 & NP & 415 & -- & -- & -- & -- & -- & -- & -- & -- \\
\hline 20N/03E-34L01 & 471034 & 1222447 & 415 & 505 & NP & 415 & 275 & 185 & 148 & 146 & 95 & 19 & -- & -- \\
\hline
\end{tabular}


Table 15.--Altitude of top of hydrogeologic units in wells in the Tacoma-Puyallup area, Washington--Continued

\begin{tabular}{|c|c|c|c|c|c|c|c|c|c|c|c|c|c|c|}
\hline \multirow{2}{*}{$\begin{array}{l}\text { Local well } \\
\text { number }\end{array}$} & \multirow[b]{2}{*}{ Latitude } & \multirow[b]{2}{*}{ Longitude } & \multirow{2}{*}{$\begin{array}{l}\text { Land } \\
\text { surface } \\
\text { altitude } \\
\text { (feet) }\end{array}$} & \multirow{2}{*}{$\begin{array}{l}\text { Hole } \\
\text { depth } \\
\text { (feet) }\end{array}$} & \multicolumn{10}{|c|}{ Altitude of top of hydrogeologic unit, in feet } \\
\hline & & & & & $\mathrm{Qvr}$ & Qvt & Qcl & Qfl & Qc2 & Qf2 & Qc3 & Qf3 & Qc4 & Qf4 \\
\hline 20N/03E-34L02 & 471034 & 1222449 & 415 & 223 & NP & 415 & 305 & -- & -- & -- & -- & -- & -- & -- \\
\hline 20N/03E-34N01 & 471022 & 1222509 & 385 & 223 & NP & 385 & 334 & 225 & 167 & -- & -- & -- & -- & -- \\
\hline 20N/03E-35C01 & 471102 & 1222331 & 410 & 315.6 & NP & 410 & 282 & 212 & 187 & 156 & -- & -- & -- & -- \\
\hline $20 \mathrm{~N} / 03 \mathrm{E}-35 \mathrm{~F} 01$ & 471050 & 1222333 & 405 & 18 & NP & 405 & -- & -- & -- & -- & -- & -- & -- & -- \\
\hline 20N/03E-35L01 & 471027 & 1222324 & 420 & 187 & NP & 420 & 243 & -- & -- & -- & -- & -- & -- & -- \\
\hline 20N/03E-35R01 & 471013 & 1222242 & 450 & 315 & NP & 450 & 277 & 219 & 194 & 154 & -- & -- & -- & -- \\
\hline 20N/03E-36D01 & 471103 & 1222236 & 415 & 34.2 & NP & 415 & -- & -- & -- & -- & -- & -- & -- & -- \\
\hline 20N/03E-36F01 & 471050 & 1222202 & 390 & 372 & NP & 390 & 326 & 270 & 183 & 124 & 82 & -- & - & -- \\
\hline 20N/03E-36P01 & 471021 & 1222206 & 428 & 597 & NP & 428 & 313 & 248 & 233 & 168 & $83 ?$ & -54 & -- & -- \\
\hline 20N/04E-18M03 & 471303 & 1222114 & 15 & 203 & NP & NP & NP & 15 & -109 & -149 & -- & -- & -- & -- \\
\hline 20N/04E-18Q01D2 & 471250 & 1222034 & 20 & 336 & NP & $\mathrm{NP}$ & NP & 20 & -96 & -210 & -280 & -- & -- & -- \\
\hline 20N/04E-19G01 & 471225 & 1222030 & 25 & 70 & NP & NP & 25 & -40 & -- & -. & -- & -- & -- & -- \\
\hline 20N/04E-19Q01 & 471202 & 1222043 & 25 & 118 & $\mathrm{NP}$ & NP & 25 & NP & -43 & -- & -- & -- & -- & -- \\
\hline 20N/04E-20D04D1 & 471236 & 1222009 & 30 & 390 & -- & -- & -- & -- & -- & -- & -266 & -- & -- & -- \\
\hline 20N/04E-20D06 & 471237 & 1222009 & 30 & 298 & NP & NP & 30 & -32 & -88 & -110 & -246 & -- & -- & -. \\
\hline 20N/04E-20E04 & 471234 & 1221954 & 30 & 56 & NP & NP & 30 & 5 & -- & -- & -- & -- & -- & -- \\
\hline $20 \mathrm{~N} / 04 \mathrm{E}-20 \mathrm{E} 06$ & 471225 & 1221948 & 25 & 121 & NP & NP & NP & 25 & -70 & -90 & -- & -. & -- & -. \\
\hline 20N/04E-20K01 & 471211 & 1221925 & 25 & 267 & NP & NP & NP & 25 & 13 & -67 & -80 & -- & -- & -- \\
\hline $20 \mathrm{~N} / 04 \mathrm{E}-20 \mathrm{~N} 05$ & 471203 & 1221956 & 30 & 193 & NP & NP & NP & 30 & -50 & -97 & -- & -- & -- & -- \\
\hline 20N/04E-20P02 & 471204 & 1221929 & 25 & 103 & NP & NP & NP & 25 & -17 & -72 & -- & -- & -- & -- \\
\hline 20N/04E-21A01 & 471244 & 1221739 & 40 & 40 & NP & NP & 40 & -- & -- & -- & -- & -- & -- & -- \\
\hline 20N/04E-21P01 & 471204 & 1221821 & 30 & 230 & NP & NP & 30 & -32 & NP & -80 & -160 & -- & -- & -- \\
\hline 20N/04E-25N01 & 471107 & 1221454 & 70 & 113 & NP & NP & NP & 70 & -10 & -- & -- & -- & -- & -- \\
\hline $\begin{array}{l}\text { 20N/04E-25P01 } \\
20 \mathrm{~N} / 04 \mathrm{E}-25 \mathrm{O} 01\end{array}$ & 471106 & 1221429 & 70 & 92 & NP & NP & NP & 70 & -20 & - & -- & -- & -- & - \\
\hline $\begin{array}{l}20 \mathrm{~N} / 04 \mathrm{E}-25 \mathrm{Q} 01 \\
20 \mathrm{~N} / 04 \mathrm{E}-26 \mathrm{E} 01\end{array}$ & 471112 & 1221417 & 60 & 105 & NP & NP & NP & 60 & -35 & -- & -- & -- & -- & -- \\
\hline $\begin{array}{l}\text { 20N/04E-26E01 } \\
\text { 20N/04E-26M01 }\end{array}$ & 471133 & 1221605 & 45 & 169 & NP & NP & 45 & 5 & -105 & -- & -- & -- & -- & -- \\
\hline $\begin{array}{l}20 \mathrm{~N} / 04 \mathrm{E}-26 \mathrm{M} 01 \\
20 \mathrm{~N} / 04 \mathrm{E}-26 \mathrm{M} 02\end{array}$ & 471130 & 1221604 & 40 & 20.5 & NP & NP & 40 & -- & -- & -- & -- & -- & - & - \\
\hline $\begin{array}{l}\text { 20N/04E-26M02 } \\
20 \mathrm{~N} / 04 \mathrm{E}-26 \mathrm{Q} 01\end{array}$ & 471130 & 1221605 & 40 & 21.5 & NP & NP & 40 & -- & -- & -- & -- & -- & -- & -- \\
\hline $\begin{array}{l}\text { 20N/04E-26Q01 } \\
\text { 20N/04E-27H01 }\end{array}$ & 471116 & 1221526 & $\begin{array}{l}65 \\
40\end{array}$ & 122 & NP & NP & 65 & 39 & -48 & -- & -- & -- & -- & - \\
\hline $\begin{array}{l}20 \mathrm{~N} / 04 \mathrm{E}-27 \mathrm{H} 01 \\
20 \mathrm{~N} / 04 \mathrm{E}-27 \mathrm{~J} 01\end{array}$ & $\begin{array}{l}471133 \\
471124\end{array}$ & $\begin{array}{l}1221619 \\
1221623\end{array}$ & $\begin{array}{l}40 \\
55\end{array}$ & 190 & $\begin{array}{l}\mathrm{NP} \\
\mathrm{NP}\end{array}$ & $\begin{array}{l}\mathrm{NP} \\
\mathrm{NP}\end{array}$ & $\begin{array}{l}40 \\
55\end{array}$ & $\begin{array}{r}-5 \\
35\end{array}$ & $\begin{array}{r}-114 \\
-95\end{array}$ & $\begin{array}{l}-119 \\
-100\end{array}$ & $\begin{array}{l}-143 \\
-152\end{array}$ & $\begin{array}{l}-- \\
--\end{array}$ & -- & -- \\
\hline & $\begin{array}{l}471124 \\
471127\end{array}$ & $\begin{array}{l}1221623 \\
1221711\end{array}$ & $\begin{array}{l}55 \\
45\end{array}$ & $\begin{array}{l}233 \\
285\end{array}$ & $\begin{array}{l}\mathrm{NP} \\
\mathrm{NP}\end{array}$ & NP & $\mathrm{NP}$ & $\begin{array}{l}35 \\
45\end{array}$ & NP & $\begin{array}{r}-100 \\
-90\end{array}$ & $\begin{array}{l}-152 \\
-203\end{array}$ & - & - & -- \\
\hline $\begin{array}{l}\text { 20N/04E-27L01 } \\
20 \mathrm{~N} / 04 \mathrm{E}-28 \mathrm{E} 01\end{array}$ & 471137 & 1221833 & 40 & 82 & $\mathrm{NP}$ & NP & 40 & 17 & -- & -- & -. & -- & -- & - \\
\hline 20N/04E-28H04 & 471131 & 1221739 & 40 & 253 & NP & NP & 40 & -5 & NP & -85 & -208 & -- & -- & - \\
\hline
\end{tabular}


Table 15.--Altitude of top of hydrogeologic units in wells in the Tacoma-Puyallup area, Washington--Continued

\begin{tabular}{|c|c|c|c|c|c|c|c|c|c|c|c|c|c|c|}
\hline \multirow{2}{*}{$\begin{array}{l}\text { Local well } \\
\text { number }\end{array}$} & \multirow[b]{2}{*}{ Latitude } & \multirow[b]{2}{*}{ Longitude } & \multirow{2}{*}{$\begin{array}{l}\text { Land } \\
\text { surface } \\
\text { altitude } \\
\text { (feet) }\end{array}$} & \multirow{2}{*}{$\begin{array}{l}\text { Hole } \\
\text { depth } \\
\text { (feet) }\end{array}$} & \multicolumn{10}{|c|}{ Altitude of top of hydrogeologic unit, in feet } \\
\hline & & & & & Qvr & Qvt & Qcl & Qfl & Qc2 & Qf2 & Qc3 & Qf3 & Qc4 & Qf4 \\
\hline 20N/04E-28H05 & 471143 & 1221734 & 40 & 20 & NP & NP & 40 & -- & -- & -- & -- & -- & -- & -- \\
\hline 20N/04E-28H06 & 471131 & 1221741 & 40 & 252 & NP & NP & 40 & -45 & $\mathrm{NP}$ & -90 & -207 & -- & -- & -- \\
\hline 20N/04E-29D03 & 471148 & 1221949 & 30 & 362 & NP & NP & NP & 30 & -45 & -100 & -- & -- & -- & -- \\
\hline 20N/04E-29P03 & 471116 & 1221931 & 50 & 119 & 50 & NP & 23 & -3 & -47 & -- & -- & -- & -- & -- \\
\hline 20N/04E-30C02 & 471150 & 1222049 & 50 & 115 & NP & 50 & -2 & -44 & -54 & -- & -- & -- & -- & -- \\
\hline 20N/04E-30C03 & 471154 & 1222049 & 30 & 42 & NP & NP & 30 & -- & -- & -- & -- & -- & -- & -- \\
\hline 20N/04E-30F01 & 471135 & 1222046 & 230 & 195 & NP & NP & 230 & NP & 132 & -- & -- & -- & $\sim$ & -- \\
\hline 20N/04E-30G02 & 471141 & 1222032 & 60 & 80 & NP & 60 & 3 & -- & -- & -- & -- & -- & -- & -- \\
\hline $20 \mathrm{~N} / 04 \mathrm{E}-30 \mathrm{H} 01$ & 471132 & 1222009 & 40 & 332 & NP & NP & 40 & 34 & $\mathrm{NP}$ & -104 & -257 & -- & -- & -- \\
\hline 20N/04E-30L02 & 471128 & 1222046 & 320 & 270 & NP & 320 & 212 & 192 & 115 & 90 & 54 & -- & -- & -- \\
\hline 20N/04E-30P02 & 471104 & 1222048 & 390 & 450 & NP & 390 & 238 & 204 & 191 & 178 & 95 & -- & -- & -- \\
\hline 20N/04E-31F02 & 471042 & 1222057 & 400 & 190 & NP & 400 & 304 & 246 & -- & -- & -- & -- & -- & -- \\
\hline $20 \mathrm{~N} / 04 \mathrm{E}-31 \mathrm{G} 01$ & 471050 & 1222030 & 350 & 126 & NP & 350 & 238 & -- & -- & -- & -- & -- & -- & $-\cdot$ \\
\hline 20N/04E-31H05 & 471039 & 1222017 & 380 & 192 & 380 & 280 & 240 & -- & -- & - & -- & -- & -- & -- \\
\hline 20N/04E-32E01 & 471045 & 1221954 & 265 & 16.5 & 265 & -- & -- & -- & -- & -- & -- & -- & -- & -- \\
\hline 20N/04E-32E02 & 471043 & 1221955 & 270 & 295 & 270 & 236 & 212 & 164 & 117 & 54 & -14 & -- & -- & -- \\
\hline 20N/04E-32H01 & 471038 & 1221851 & 31.7 & 170 & NP & NP & 32 & -42 & -75 & -133 & -- & -- & -- & -- \\
\hline $20 \mathrm{~N} / 04 \mathrm{E}-32 \mathrm{H} 02$ & 471039 & 1221851 & 30 & 171.5 & NP & $\mathrm{NP}$ & 30 & -53 & -77 & -131 & -- & -- & -- & -- \\
\hline 20N/04E-32J02 & 471039 & 1221852 & 30 & 166 & NP & NP & 30 & -48 & -77 & -132 & -- & -- & -- & -- \\
\hline 20N/04E-32R02 & 471015 & 1221851 & 300 & 294 & 300 & 289 & 240 & 178 & 122 & 9 & -- & -- & -- & -- \\
\hline 20N/04E-33A01 & 471055 & 1221733 & 40 & 345 & NP & NP & 40 & -60 & -95 & -122 & -186 & -200 & -265 & -- \\
\hline 20N/04E-34B01 & 471053 & 1221640 & 55 & 42 & NP & NP & 55 & -- & -- & -- & -- & -- & -- & -- \\
\hline $20 \mathrm{~N} / 04 \mathrm{E}-34 \mathrm{C} 01$ & 471054 & 1221711 & 45 & 264 & NP & NP & 45 & -85 & -109 & -127 & -202 & -- & -- & -- \\
\hline 20N/04E-34E01 & 471048 & 1221731 & 50 & 43 & NP & NP & 50 & -- & -- & -- & -- & -- & -- & -- \\
\hline $20 \mathrm{~N} / 04 \mathrm{E}-34 \mathrm{G} 01$ & 471041 & 1221650 & 140 & 573.5 & NP & 140 & NP & 55 & -70 & -94 & -154 & -227 & -282 & -330 \\
\hline 20N/04E-34N01 & 471015 & 1221720 & 330 & 347 & 330 & 303 & NP & 75 & 40 & 15 & -- & -- & -- & -- \\
\hline $20 \mathrm{~N} / 04 \mathrm{E}-35 \mathrm{~A} 02$ & 471100 & 1221515 & 70 & 116 & NP & NP & 70 & 44 & -24 & -- & -- & -- & -- & -- \\
\hline 20N/04E-35B01 & 471053 & 1221521 & 80 & 22 & NP & NP & 80 & -. & -- & -- & -- & -- & -- & -- \\
\hline 20N/04E-35D01 & 471102 & 1221600 & 65 & 61 & NP & $\mathrm{NP}$ & 65 & -3 & -60 & -- & -- & -- & -- & -- \\
\hline 20N/04E-35E01 & 471049 & 1221603 & 65 & 46 & NP & NP & 65 & -- & -- & -- & -- & -- & -- & -- \\
\hline 20N/04E-35J06 & 471029 & 1221500 & 260 & 250 & NP & 260 & 185 & 170 & 15 & -- & -. & -- & -- & -- \\
\hline 20N/04E-35M01 & 471034 & 1221559 & 280 & 296.5 & 280 & 263 & 213 & 146 & 11 & -- & -- & -- & -- & -- \\
\hline 20N/04E-35M02 & 471034 & 1221559 & 280 & 341 & 280 & 263 & 198 & 146 & 10 & -- & -- & -- & -- & -- \\
\hline 20N/04E-35R02 & 471020 & 1221506 & 280 & 220 & NP & 280 & 213 & 173 & 75 & -- & & -- & -- & -- \\
\hline
\end{tabular}


Table 15.--Altitude of top of hydrogeologic units in wells in the Tacoma-Puyallup area, Washington--Continued

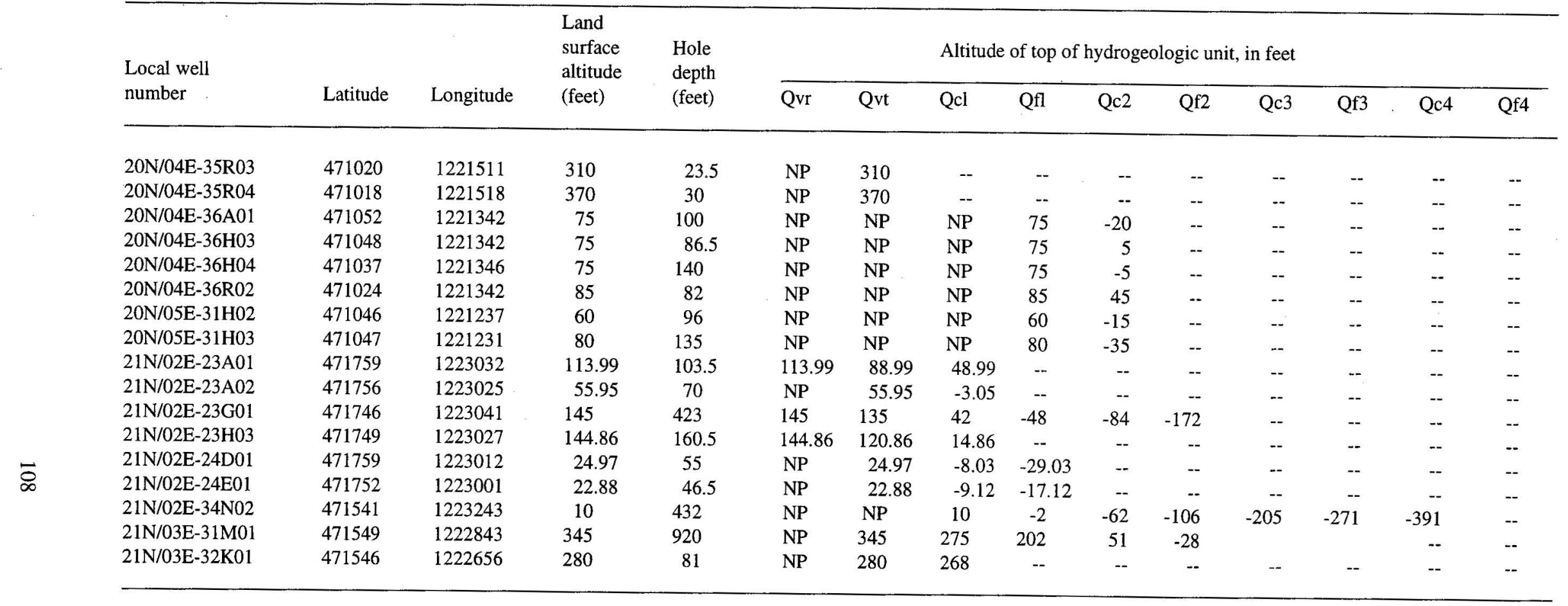




\section{Appendix 1.--Physical and hydrologic data for the wells and springs in the Tacoma-Puyallup area, Washington}

\section{EXPLANATION}

Land surface altitude:

Tag number:

Latitude and Longitude:

Well depth:

Water use:

Hydrogeologic unit:

Water level:

Date:

Hydraulic conductivity:

Remarks:
In feet above sea level. Most altitudes were determined from topographic maps (scale 1:24,000 with 10- or 20-foot contour intervals) and are generally accurate to within half of the contour interval, 5 or 10 feet, respectively. In steep terrain or where the precise location of the well is in doubt, the error may be as great as 50 feet. Some wells $(<10$ percent) have been surveyed and have land surface altitudes accurate to within 1 foot.

Washington Department of Ecology identification tag.

Most well locations are believed to be accurate to within 1 second of latitude and longitude. The least accurate locations are probably within 10 seconds of latitude and longitude.

Feet below land surface.

Primary water use: A, air conditioning; $\mathrm{B}$, bottling; $\mathrm{C}$, commercial; $\mathrm{D}$, de-water; $\mathrm{H}$, domestic; J, industrial cooling; I, irrigation; N, industrial; P, public supply; Q, aquaculture; S, stock; U, unused; Z, other; ,-- no data.

Hydrogeologic unit tapped by well: MLT, well taps multiple units; --, unit tapped not determined.

Feet below land surface. Minus sign indicates water level above land surface. Water levels measured with steel tape are accurate to nearest 0.01 foot; with electric tape accurate to nearest 0.1 foot; *, reported water levels; $\mathrm{D}$, dry; F, flowing; $P$, pumping; $R$, recently pumped; $S$, nearby well pumping; $T$, nearby well recently pumped; --, no data.

Date water level measured. In some cases, only incomplete dates are available.

Feet per day; ${ }^{a}$, duration of pumping unknown, assumed pumping time of 1 hour for calculation of hydraulic conductivity.

D, driller's log available; G, geologist's log available; $\mathrm{X}$, used in constructing hydrogeologic section; $\mathrm{W}$, project observation well for water level and where available specific conductance; I, sampled for major ions, bacteria, arsenic, and nitrate; $\mathrm{M}$, sampled for MBAS detergents and boron; $\mathrm{T}$, sampled for trace elements; $V$, sampled for volatile organic carbons; $P$, sampled for pesticides; R, sampled for radon; $\mathrm{C}$, sampled for organic carbon. 
Appendix 1.--Physical and hydrologic data for the wells and springs in the Tacoma-Puyallup area, Washington--Continued

\begin{tabular}{|c|c|c|c|c|c|c|c|c|c|c|c|}
\hline $\begin{array}{l}\text { Local well } \\
\text { number }\end{array}$ & $\begin{array}{l}\text { Tag } \\
\text { number }\end{array}$ & Latitude & Longitude & $\begin{array}{l}\text { Land } \\
\text { surface } \\
\text { altitude } \\
\text { (feet) }\end{array}$ & $\begin{array}{l}\text { Well } \\
\text { depth } \\
\text { (feet) }\end{array}$ & $\begin{array}{l}\text { Water } \\
\text { use }\end{array}$ & $\begin{array}{l}\text { Geo- } \\
\text { hydro- } \\
\text { logic } \\
\text { unit }\end{array}$ & $\begin{array}{l}\text { Water } \\
\text { level } \\
\text { (feet) }\end{array}$ & Date & $\begin{array}{l}\text { Hydraulic } \\
\text { conductivity } \\
\text { (feet per day) }\end{array}$ & Remarks \\
\hline $19 \mathrm{~N} / 03 \mathrm{E}-01 \mathrm{~A} 01$ & ACA 800 & 471007 & 1222136 & 460 & 291 & $\mathrm{P}$ & Qc2 & $\mathrm{P}$ & $06-26-95$ & 28 & $\mathrm{D}$ \\
\hline $19 \mathrm{~N} / 03 \mathrm{E}-01 \mathrm{C} 01$ & & 471009 & 1222201 & 430 & 184 & $\mathrm{H}$ & Qc2 & $173 * *$ & $09-10-53$ & 1,700 & $\mathrm{D}$ \\
\hline $19 \mathrm{~N} / 03 \mathrm{E}-01 \mathrm{C} 02$ & ACA601 & 470959 & 1222200 & 445 & 192 & $\mathbf{H}$ & Qc2 & 181.36 & $05-11-95$ & 1,900 & $\mathrm{D}$ \\
\hline $19 \mathrm{~N} / 03 \mathrm{E}-01 \mathrm{E} 01$ & ACA797 & 470958 & 1222230 & 473.8 & 282 & $\mathrm{P}$ & Qc2 & $210.5^{*}$ & $03-21-51$ & 25 & $\mathrm{D}, \mathrm{X}, \mathrm{I}, \mathrm{R}, \mathrm{C}$ \\
\hline 19N/03E-01G02 & ACA796 & 470944 & 1222146 & 450 & 236 & $\mathrm{P}$ & Qc2 & 198.10 & $06-29-95$ & 150 & $\mathrm{D}, \mathrm{X}, \mathrm{W}$ \\
\hline 19N/03E-01J01 & & 470941 & 1222137 & 475 & 230 & $\mathrm{U}$ & Qc2 & $193.1^{*}$ & $05-10-50$ & 96 & $\mathrm{D}, \mathrm{X}$ \\
\hline 19N/03E-03B01 & & 471000 & 1222420 & 430 & 294 & $\mathrm{P}$ & MLT & $181 .^{*}$ & $04-14-70$ & -- & $\mathrm{D}$ \\
\hline 19N/03E-03B02 & & 471010 & 1222421 & 425 & 427 & $\mathbf{U}$ & Qc3 & 202.22 & $07-25-95$ & 9.6 & $\mathrm{D}, \mathrm{W}$ \\
\hline $19 \mathrm{~N} / 03 \mathrm{E}-03 \mathrm{~F} 02$ & & 470949 & 1222445 & 405 & 383 & $\mathrm{P}$ & Qc3 & $158.65 *$ & $03-13-85$ & 99 & $\mathrm{D}, \mathrm{X}$ \\
\hline $19 \mathrm{~N} / 03 \mathrm{E}-03 \mathrm{~F} 04$ & & 470951 & 1222447 & 405 & 370 & $\mathrm{P}$ & Qc3 & $194.93 \mathrm{~S}$ & $05-15-95$ & 310 & $\mathrm{D}, \mathrm{X}$ \\
\hline 19N/03E-03G01 & & 470959 & 1222420 & 430 & 415 & $\mathrm{U}$ & MLT & $191.71 \mathrm{~S}$ & $05-15-95$ & -- & $\mathrm{D}$ \\
\hline 19N/03E-03G02 & & 470955 & 1222423 & 430 & 422 & $\mathrm{U}$ & $\mathrm{Qc2}$ & $183 *^{*}$ & $01-01-58$ & $33^{\mathrm{a}}$ & $\mathrm{D}, \mathrm{X}$ \\
\hline $19 \mathrm{~N} / 03 \mathrm{E}-10 \mathrm{P} 02$ & & 470838 & 1222444 & 380 & 13 & $\mathbf{U}$ & Qvt & 1.79 & $05-09-95$ & -- & \\
\hline $19 \mathrm{~N} / 03 \mathrm{E}-11 \mathrm{G} 03$ & ABS617 & 470852 & 1222306 & 420 & 238 & $\mathrm{P}$ & MLT & 169.05 & $07-29-95$ & -- & $\mathrm{D}, \mathrm{W}$ \\
\hline 19N/03E-11Q01 & ACA604 & 470833 & 1222302 & 415 & 237 & $\mathrm{H}$ & Qc2 & 157.31 & $05-09-95$ & -- & $\mathrm{D}, \mathrm{I}, \mathrm{R}, \mathrm{C}$ \\
\hline 19N/03E-13R01 & ACA851 & 470733 & 1222127 & 455 & 161 & $\mathrm{H}$ & Qc1 & 148.65 & $05-02-95$ & 306 & $\mathrm{D}$ \\
\hline $19 \mathrm{~N} / 03 \mathrm{E}-25 \mathrm{C} 01$ & ACA883 & 470629 & 1222212 & 350 & 51 & $\mathrm{H}$ & Qvt & $18.68 \mathrm{~S}$ & $06-08-95$ & 23 & $\mathrm{D}$ \\
\hline $19 \mathrm{~N} / 04 \mathrm{E}-01 \mathrm{~A} 01$ & & 471006 & 1221344 & 90 & 96 & $\mathrm{U}$ & Qc2 & -- & - & 260 & $\mathrm{D}$ \\
\hline 19N/04E-01D01S & & 471011 & 1221457 & 320 & - & $\mathrm{U}$ & Qvr & -- & -- & -- & \\
\hline 19N/04E-01H01 & ACA511 & 470949 & 1221344 & 95 & 197 & $\mathrm{H}$ & Qc2 & 13.90 & $05-09-95$ & -- & $\mathrm{D}$ \\
\hline 19N/04E-01J01 ${ }^{1}$ & & 470930 & 1221348 & 105 & 100 & I & Qc2 & $11 *$ & $06-10-51$ & 186 & \\
\hline 19N/04E-01Q01 & ACA509 & 470925 & 1221403 & 110 & 104 & I & Qc2 & 23.22 & $05-09-95$ & $420 .^{a}$ & $\mathrm{D}, \mathrm{X}$ \\
\hline 19N/04E-02F01 & ACA505 & 470955 & 1221542 & 410 & 623 & $\mathrm{P}$ & Qc3 & 322.5 & $07-05-95$ & 100 & $\mathrm{D}, \mathrm{I}, \mathrm{R}, \mathrm{C}$ \\
\hline 19N/04E-02J01 & & 470931 & 1221500 & 500 & 425 & $\mathrm{U}$ & Qc2 & $387 . *$ & $04-29-59$ & 41 & $\mathrm{D}, \mathrm{X}$ \\
\hline 19N/04E-03A01D1 & ACA528 & 471008 & 1221628 & 445 & 740 & $\mathrm{P}$ & MLT & 400.00 & $08-25-95$ & -- & $\mathrm{D}, \mathrm{X}$ \\
\hline $19 \mathrm{~N} / 04 \mathrm{E}-03 \mathrm{~K} 02$ & & 470938 & 1221650 & 460 & 33 & $\mathrm{U}$ & Qvr & 24.72 & $07-24-95$ & -- & G,W \\
\hline 19N/04E-03K03 & & 470937 & 1221648 & 460 & 45 & $\mathrm{U}$ & Qvr & 28.89 & $07-24-95$ & -- & $\mathrm{G}, \mathrm{W}$ \\
\hline $19 \mathrm{~N} / 04 \mathrm{E}-03 \mathrm{~K} 04$ & & 470939 & 1221651 & 450 & 35 & $\mathrm{U}$ & Qvr & 27.04 & $07-24-95$ & - & $\mathrm{G}, \mathrm{W}$ \\
\hline 19N/04E-03Q01 & & 470930 & 1221637 & 500 & 42.3 & $\mathrm{U}$ & Qvt & 32.85 & $07-24-95$ & -- & $\mathrm{G}, \mathrm{X}, \mathrm{W}$ \\
\hline 19N/04E-03R01D2 & & 470919 & 1221632 & 530 & 612 & $\mathrm{P}$ & Qc3 & $409 . *$ & $02-24-81$ & 120 & $\mathrm{D}, \mathrm{X}, \mathrm{I}, \mathrm{M}, \mathrm{T}, \mathrm{R}, \mathrm{C}$ \\
\hline 19N/04E-04L01 & ACA985 & 470935 & 1221819 & 355 & 240 & $\mathrm{U}$ & Qc2 & 238.40 & $06-04-85$ & 41 & $\mathrm{D}$ \\
\hline 19N/04E-04L02 & ACA895 & 470934 & 1221819 & 355 & 264 & $\mathrm{P}$ & Qc2 & $219 .^{*}$ & $10-15-64$ & 1,600 & $\mathrm{D}, \mathrm{I}$ \\
\hline 19N/04E-04Q01 & & 470928 & 1221805 & 410 & 327 & $\mathrm{U}$ & Qc2 & $264 . *$ & $11---58$ & 1,800 & $\mathrm{D}$ \\
\hline 19N/04E-05P02 & ABR143 & 470922 & 1221945 & 435 & 258 & $\mathrm{P}$ & Qc2 & 223.64 & $06-20-95$ & 12,000 & $\mathrm{D}, \mathrm{X}$ \\
\hline 19N/04E-06J02 & ACA512 & 470934 & 1222011 & 440 & 207 & $\mathrm{P}$ & Qc2 & 176.65 & $05-04-95$ & 53 & $\mathrm{D}$ \\
\hline
\end{tabular}


Appendix 1.--Physical and hydrologic data for the wells and springs in the Tacoma-Puyallup area, Washington--Continued

\begin{tabular}{|c|c|c|c|c|c|c|c|c|c|c|c|}
\hline $\begin{array}{l}\text { Local well } \\
\text { number }\end{array}$ & $\begin{array}{l}\text { Tag } \\
\text { number }\end{array}$ & Latitude & Longitude & $\begin{array}{l}\text { Land } \\
\text { surface } \\
\text { altitude } \\
\text { (feet) }\end{array}$ & $\begin{array}{l}\text { Well } \\
\text { depth } \\
\text { (feet) }\end{array}$ & $\begin{array}{l}\text { Water } \\
\text { use }\end{array}$ & $\begin{array}{l}\text { Geo- } \\
\text { hydro- } \\
\text { logic } \\
\text { unit }\end{array}$ & $\begin{array}{l}\text { Water } \\
\text { level } \\
\text { (feet) }\end{array}$ & Date & $\begin{array}{l}\text { Hydraulic } \\
\text { conductivity } \\
\text { (feet per day) }\end{array}$ & Remarks \\
\hline $19 \mathrm{~N} / 04 \mathrm{E}-06 \mathrm{~K} 01^{1}$ & & 470941 & 1222040 & 480 & 203 & $\mathrm{H}$ & Qc2 & $168 .^{*}$ & $04-30-63$ & 300 & \\
\hline 19N/04E-06N01 & & 470929 & 1222109 & 420 & 22.8 & $\mathrm{U}$ & Qvt & 1.48 & $02-28-40$ & -- & \\
\hline 19N/04E-07A01 & & 470911 & 1222010 & 415 & 36.6 & $\mathrm{U}$ & Qvt & 19.70 & $05-10-60$ & -- & $\mathrm{D}$ \\
\hline 19N/04E-07D01 & ACA798 & 470912 & 1222105 & 450 & 326 & $\mathrm{P}$ & Qc2 & $195 .^{*}$ & $04-29-55$ & -- & $\mathrm{D}$ \\
\hline $19 \mathrm{~N} / 04 \mathrm{E}-07 \mathrm{D} 02$ & ACA795 & 470912 & 1222103 & 450 & 220 & $P$ & Qc2 & $194.67^{*}$ & $08-22-66$ & -- & $\mathrm{D}$ \\
\hline 19N/04E-07F01D1 & ACA794 & 470901 & 1222057 & 460 & 602 & $\mathrm{P}$ & Qc4 & 271.15 & $06-30-95$ & -- & $\mathrm{D}$ \\
\hline $19 \mathrm{~N} / 04 \mathrm{E}-07 \mathrm{~F} 02$ & & 470900 & 1222100 & 455 & 239.58 & $\mathrm{U}$ & Qc1 & $210{ }^{*}$ & $02-01-88$ & 19 & $\mathrm{D}$ \\
\hline 19N/04E-07N01 & & 470826 & 1222118 & 475 & 12.9 & $\mathrm{U}$ & Qvt & $2.69 *$ & $02-29-40$ & -- & $\mathrm{D}$ \\
\hline 19N/04E-08A01 & & 470911 & 1221859 & 346.29 & 297 & $\mathrm{P}$ & Qc2 & $219 .^{*}$ & $07-20-95$ & $2,200 .^{\mathrm{a}}$ & $\mathrm{D}, \mathrm{X}$ \\
\hline $19 \mathrm{~N} / 04 \mathrm{E}-08 \mathrm{~A} 02^{1}$ & & 470912 & 1221858 & 349 & 315 & $\mathbf{U}$ & Qc2 & 222 & $03-07-63$ & 2,700 & \\
\hline $19 \mathrm{~N} / 04 \mathrm{E}-08 \mathrm{~A} 06$ & & 470909 & 1221851 & 366.5 & 353.3 & $\mathrm{P}$ & Qc2 & $225.5^{*}$ & $07-02-65$ & 300 & $\mathrm{D}, \mathrm{X}$ \\
\hline 19N/04E-08D01 & ACA506 & 470913 & 1221958 & 420 & 258 & $\mathrm{H}$ & Qc2 & $178 . *$ & $06-15-81$ & 24 & $\mathrm{D}, \mathrm{X}$ \\
\hline 19N/04E-08K01 & ACA894 & 470849 & 1221915 & 440 & 340 & $\mathrm{P}$ & Qc2 & 272.14 & $06-20-95$ & -- & $\mathrm{G}$ \\
\hline 19N/04E-08P01 & & 470837 & 1221937 & 460 & 17.7 & $\mathrm{U}$ & Qvt & $1.8^{*}$ & $05-09-60$ & -- & \\
\hline 19N/04E-09B01 & ABS168 & 470914 & 1221808 & 410 & 324 & $\mathrm{U}$ & Qc2 & 273.93 & $06-20-95$ & $8,500^{a}$ & $\mathrm{D}, \mathrm{W}$ \\
\hline 19N/04E-09B02 & ABS167 & 470914 & 1221807 & 410 & 316 & $P$ & Qc2 & $273.38 \mathrm{R}$ & $06-20-95$ & 8,700 & $\mathrm{D}, \mathrm{W}$ \\
\hline $19 \mathrm{~N} / 04 \mathrm{E}-09 \mathrm{~B} 03$ & AAT387 & 470914 & 1221808 & 410 & 350 & $P$ & Qc2 & 273.63 & $06-20-95$ & 8,100 & $\mathrm{D}, \mathrm{X}, \mathrm{W}$ \\
\hline 19N/04E-10A01 & & 470905 & 1221619 & 570 & 271 & $\mathrm{H}$ & Qc1 & $235 .^{*}$ & $05-16-77$ & 610 & $\mathrm{D}, \mathrm{X}$ \\
\hline $19 \mathrm{~N} / 04 \mathrm{E}-11 \mathrm{D} 01$ & ACA527 & 470903 & 1221600 & 450 & 119.5 & $\mathrm{H}$ & Qc1 & 88.28 & $05-12-95$ & -- & $\mathrm{D}, \mathrm{X}, \mathrm{I}, \mathrm{M}, \mathrm{P}$ \\
\hline $19 \mathrm{~N} / 04 \mathrm{E}-11 \mathrm{D} 02$ & ACA501 & 470905 & 1221613 & 560 & 280 & $\mathrm{H}$ & Qc1 & 205.81 & $05-03-95$ & -. & $\mathrm{D}, \mathrm{X}, \mathrm{W}$ \\
\hline $19 \mathrm{~N} / 04 \mathrm{E}-11 \mathrm{~K} 02$ & & 470850 & 1221529 & 515 & 46 & $\mathrm{U}$ & Qvt & 26.09 & $05-18-95$ & -- & \\
\hline $19 \mathrm{~N} / 04 \mathrm{E}-12 \mathrm{~A} 02$ & ACA502 & 470911 & 1221342 & 110 & 76 & I & Qc2 & $12 *^{*}$ & $06-24-74$ & $1,800^{\circ}$ & $\mathrm{D}$ \\
\hline $19 \mathrm{~N} / 04 \mathrm{E}-12 \mathrm{~B} 01$ & & 470906 & 1221404 & 110 & 54 & I & Qc2 & $18 .^{*}$ & $08-21-75$ & 152 & $\mathrm{D}$ \\
\hline $19 \mathrm{~N} / 04 \mathrm{E}-12 \mathrm{H} 02$ & ACA504 & 470902 & 1221358 & 110 & 140.5 & I & $Q c 2$ & $12 .^{*}$ & $05-12-88$ & -- & $\mathrm{D}$ \\
\hline $19 \mathrm{~N} / 04 \mathrm{E}-12 \mathrm{H} 03$ & & 470859 & 1221355 & 110 & 124 & I & Qc2 & $14 .^{*}$ & $12-27-51$ & 76 & $\mathrm{D}$ \\
\hline $19 \mathrm{~N} / 04 \mathrm{E}-12 \mathrm{J01} 1^{l}$ & & 470848 & 1221355 & 110 & 85 & I & Qc2 & 19.9 & $05-16-60$ & 1,500 & \\
\hline $19 \mathrm{~N} / 04 \mathrm{E}-12 \mathrm{~J} 02$ & & 470845 & 1221353 & 110 & 125 & I & $\mathrm{Qc2}$ & $18{ }^{*}$ & $05-16-60$ & -- & $\mathrm{D}$ \\
\hline $19 \mathrm{~N} / 04 \mathrm{E}-12 \mathrm{~N} 01 \mathrm{~S}$ & & 470834 & 1221442 & 300 & -- & $\mathbf{U}$ & Qvr & -- &.- & -- & $\mathrm{I}, \mathrm{M}, \mathrm{T}, \mathrm{V}, \mathrm{P}$ \\
\hline $19 \mathrm{~N} / 04 \mathrm{E}-12 \mathrm{Q} 01$ & & 470832 & 1221401 & 120 & -- & $\mathbf{H}$ & - & -- & - & .. & \\
\hline 19N/04E-12R02 & & 470825 & 1221345 & 120 & 77 & I & Qc2 & 17.65 & $05-08-95$ & -- & $\mathrm{D}$ \\
\hline $19 \mathrm{~N} / 04 \mathrm{E}-13 \mathrm{~B} 01$ & & 470818 & 1221412 & 120 & 117 & I & Qc2 & 21.11 & $05-09-95$ & 44 & $\mathrm{D}$ \\
\hline $19 \mathrm{~N} / 04 \mathrm{E}-13 \mathrm{D} 01 \mathrm{~S}$ & & 470820 & 1221443 & 295 & - & $\mathrm{U}$ & -- & -. & - & -- & \\
\hline 19N/04E-13G01 & ACA531 & 470802 & 1221401 & 115 & 80 & $\mathbf{H}$ & Qc2 & 11.15 & $05-18-95$ & 49 & $\mathrm{D}$ \\
\hline $19 \mathrm{~N} / 04 \mathrm{E}-13 \mathrm{~K} 02$ & & 470755 & 1221406 & 120 & 14 & $\mathbf{U}$ & Qc1 & 6.58 & $05-16-60$ & -- & $\mathrm{D}$ \\
\hline 19N/04E-14M01 & & 470749 & 1221612 & 530 & 11.1 & $\mathbf{U}$ & Qvr & 3.92 & $05-25-95$ &.- & W \\
\hline
\end{tabular}


Appendix 1.--Physical and hydrologic data for the wells and springs in the Tacoma-Puyallup area, Washington--Continued

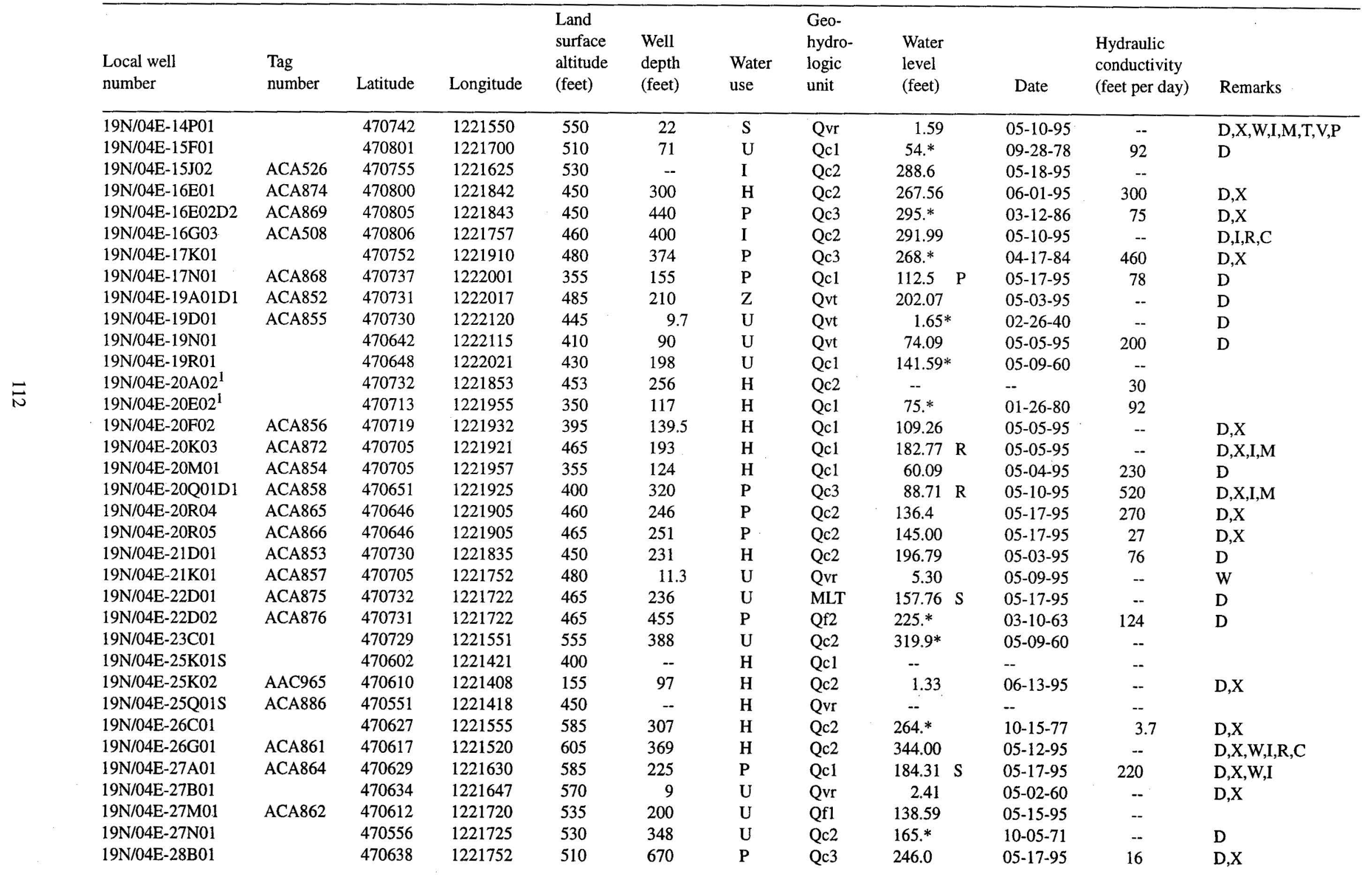


Appendix 1.--Physical and hydrologic data for the wells and springs in the Tacoma-Puyallup area, Washington--Continued

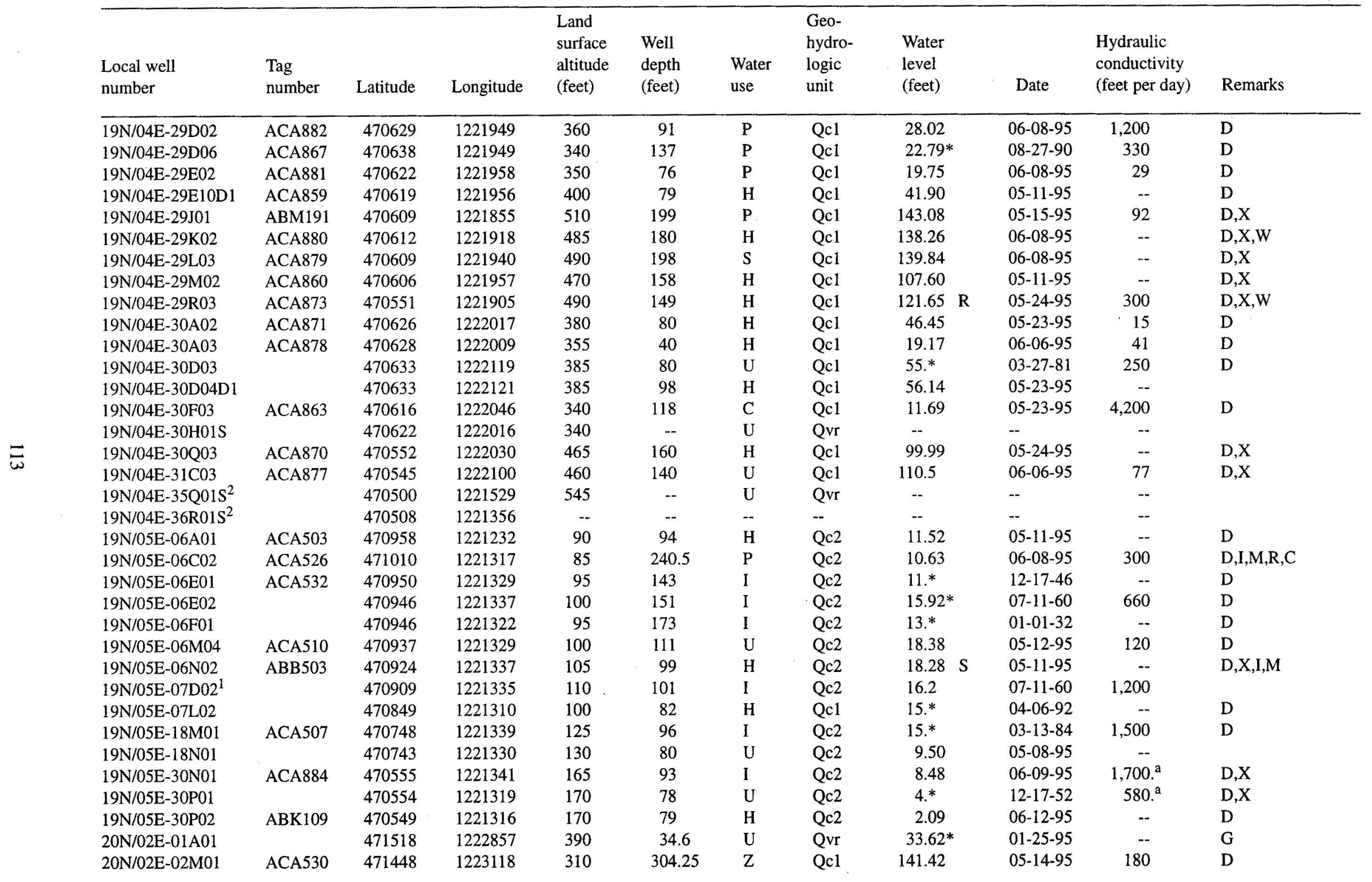


Appendix 1.--Physical and hydrologic data for the wells and springs in the Tacoma-Puyallup area, Washington--Continued

\begin{tabular}{|c|c|c|c|c|c|c|c|c|c|c|c|}
\hline $\begin{array}{l}\text { Local well } \\
\text { number }\end{array}$ & $\begin{array}{l}\text { Tag } \\
\text { number }\end{array}$ & Latitude & Longitude & $\begin{array}{l}\text { Land } \\
\text { surface } \\
\text { altitude } \\
\text { (feet) }\end{array}$ & $\begin{array}{l}\text { Well } \\
\text { depth } \\
\text { (feet) }\end{array}$ & $\begin{array}{l}\text { Water } \\
\text { use }\end{array}$ & $\begin{array}{l}\text { Geo- } \\
\text { hydro- } \\
\text { logic } \\
\text { unit }\end{array}$ & $\begin{array}{l}\text { Water } \\
\text { level } \\
\text { (feet) }\end{array}$ & Date & $\begin{array}{l}\text { Hydraulic } \\
\text { conductivity } \\
\text { (feet per day) }\end{array}$ & Remarks \\
\hline 20N/02E-02M02 & ACA529 & 471448 & 1223120 & 323 & 195.25 & $\mathrm{Z}$ & Qc1 & 115.1 & $06-14-95$ & -- & $\mathrm{D}$ \\
\hline $20 \mathrm{~N} / 02 \mathrm{E}-12 \mathrm{H} 01$ & & 471417 & 1222904 & 400 & 218 & $\mathrm{U}$ & Qc1 & $172 .^{*}$ & -----40 & -- & D \\
\hline 20N/02E-12M01 & & 471359 & 1222956 & 283.96 & 75 & $\mathrm{U}$ & Qcl & $67.94 *$ & $05-04-95$ & -- & $\mathrm{G}, \mathrm{W}$ \\
\hline 20N/02E-12M02 & & 471359 & 1222956 & 284.45 & 105 & $\mathrm{U}$ & Qc1 & $67.04 *$ & $05-04-95$ & -- & $\mathrm{G}, \mathrm{W}$ \\
\hline $20 \mathrm{~N} / 02 \mathrm{E}-12 \mathrm{Q} 01$ & & 471353 & 1222931 & 326.88 & 113 & $\mathrm{U}$ & Qc1 & 110.19 & $09-08-95$ & -- & $\mathrm{G}, \mathrm{W}$ \\
\hline 20N/03E-03L01 & & 471451 & 1222440 & 10 & 527 & $\mathbf{J}$ & Qc5 & $-11 . \quad F$ & $04-01-60$ & 680 & $\mathrm{D}$ \\
\hline 20N/03E-04M01 & & 471455 & 1222622 & 140 & 25 & $\mathrm{U}$ & Qvt & 8.* & $10-05-93$ & -- & $\mathrm{D}$ \\
\hline 20N/03E-04P01 & & 471434 & 1222558 & 15 & 385 & $\mathrm{U}$ & MLT & $\mathrm{F}$ & $06-09-60$ & -- & \\
\hline 20N/03E-05C01 & & 471524 & 1222706 & 345 & 24 & $\mathrm{U}$ & Qvt & -- & -- & -- & G \\
\hline 20N/03E-06M01 & & 471459 & 1222855 & 360.11 & 30 & $\mathrm{U}$ & Qvr & $21.76^{*}$ & $07-13-94$ & -- & G \\
\hline 20N/03E-06M02 & & 471500 & 1222855 & 360 & 30 & $\mathrm{U}$ & Qvr & D & $01-06-94$ & -- & G \\
\hline 20N/03E-06N01 & & 471441 & 1222855 & 360 & 291 & $\mathrm{U}$ & Qc2 & 156.84 & $07-18-95$ & 230 & $\mathrm{D}, \mathrm{W}$ \\
\hline 20N/03E-07F01 & ACA890 & 471420 & 1222830 & 330 & 160 & I & Qc1 & 99.38 & $06-15-95$ & 130 & $\mathrm{D}, \mathrm{W}, \mathrm{I}, \mathrm{M}, \mathrm{T}, \mathrm{V}, \mathrm{P}$ \\
\hline 20N/03E-07G01 & ACA899 & 471420 & 1222813 & 350 & 169 & I & Qc1 & 140.00 & $03-22-60$ & 670 & D \\
\hline 20N/03E-07NO2 & & 471351 & 1222847 & 250 & 200 & $\mathbf{U}$ & Qc2 & $17 . *$ & $01----.40$ & -- & D \\
\hline 20N/03E-07Q01 & & 471354 & 1222809 & 270 & 141 & $J$ & Qc2 & $100 *$ & $10-22-34$ & 87 & $\mathrm{D}$ \\
\hline $20 \mathrm{~N} / 03 \mathrm{E}-08 \mathrm{~J} 01 \mathrm{~S}$ & & 471359 & 1222630 & 180 & -- & $\mathrm{U}$ & Qc1 & -- & -- & -- & \\
\hline 20N/03E-08K03 & & 471357 & 1222649 & 240 & 38 & $\mathbf{U}$ & $\mathrm{Qcl}$ & $33 *^{*}$ & $09-26-92$ & -- & $\mathrm{G}$ \\
\hline 20N/03E-09A03 & ACA892 & 471421 & 1222513 & 10 & 248 & $\mathrm{~N}$ & Qc3 & 1.0 & $06-16-95$ & 250 & $\mathrm{D}, \mathrm{I}, \mathrm{R}, \mathrm{C}$ \\
\hline 20N/03E-09C02 & & 471428 & 1222557 & 40 & 301 & $\mathrm{U}$ & $\mathrm{Q} c 2$ & F & $04---59$ & $14 .^{\mathrm{a}}$ & $\mathrm{D}$ \\
\hline 20N/03E-09D03 & ACA893 & 471428 & 1222615 & 110 & 652 & $\mathrm{U}$ & Qc3 & $54 . *$ & $05-01-60$ & 31 & $\mathrm{D}$ \\
\hline 20N/03E-09D04 ${ }^{1}$ & & 471425 & 1222621 & 105.95 & 540 & B & Qc3 & $65 .^{*}$ & $03-15-60$ & 44 & \\
\hline 20N/03E-09E03 & & 471417 & 1222615 & 150 & 259 & $\mathbf{J}$ & Qc1 & 78.83 & $10-08-85$ & -. & $\mathrm{D}$ \\
\hline $20 \mathrm{~N} / 03 \mathrm{E}-09 \mathrm{E}^{1} 4^{1}$ & & 471413 & 1222610 & 125 & 710 & $\mathrm{~N}$ & Qc1 & 112 & $03-15-60$ & 68 & \\
\hline 20N/03E-09F01 & & 471419 & 1222554 & 60 & 618 & $\mathrm{U}$ & Qc3 & $\mathrm{F}$ & $05-30-85$ & 110 & $\mathrm{D}$ \\
\hline 20N/03E-09M01S & & 471358 & 1222624 & 180 & -- & $\mathrm{U}$ & Qcl & -- & -- & -- & \\
\hline 20N/03E-09N01S & & 471347 & 1222624 & 175 & -- & $\mathrm{U}$ & Qc1 & -- & -- & -- & \\
\hline 20N/03E-09P01S & & 471347 & 1222549 & 165 & -- & $\mathrm{U}$ & -- &.- & -- & -- & \\
\hline 20N/03E-09Q01S & & 471344 & 1222539 & 225 & -- & $\mathrm{U}$ & Qc1 & -- & -- & -- & \\
\hline 20N/03E-10G01 & & 471419 & 1222430 & 40 & 30 & $\mathrm{Z}$ & Qc1 & $12 .^{*}$ & $02-23-94$ & -- & G \\
\hline 20N/03E-11K01 & ACA 887 & 471400 & 1222310 & 15 & 97 & $\mathbf{P}$ & Qc2 & 7.68 & $06-14-95$ & 130 & $\mathrm{D}$ \\
\hline 20N/03E-11P02 & & 471343 & 1222327 & 25 & 41 & $\mathrm{U}$ & Qc2 & 4.70 & $05-22-85$ & 20 & $\mathrm{D}$ \\
\hline 20N/03E-11P04 & & 471341 & 1222322 & 25 & 88 & $\mathbf{H}$ & Qc2 & $\mathrm{F}$ & $05-22-85$ & 18 & D \\
\hline 20N/03E-11P05 & ACA 885 & 471343 & 1222329 & 35 & 25 & $\mathbf{H}$ & Qc1 & 9.47 & $06-13-95$ & -- & $\mathrm{I}, \mathrm{M}, \mathrm{T}, \mathrm{V}, \mathrm{P}$ \\
\hline 20N/03E-11Q02 & ACA792 & 471351 & 1222309 & 10 & 315 & $\mathbf{P}$ & Qc4 & $\mathrm{F}$ & $07-07-95$ & 61 & D \\
\hline
\end{tabular}


Appendix 1.--Physical and hydrologic data for the wells and springs in the Tacoma-Puyallup area, Washington--Continued

\begin{tabular}{|c|c|c|c|c|c|c|c|c|c|c|c|}
\hline $\begin{array}{l}\text { Local well } \\
\text { number }\end{array}$ & $\begin{array}{l}\text { Tag } \\
\text { number }\end{array}$ & Latitude & Longitude & $\begin{array}{l}\text { Land } \\
\text { surface } \\
\text { altitude } \\
\text { (feet) }\end{array}$ & $\begin{array}{l}\text { Well } \\
\text { depth } \\
\text { (feet) }\end{array}$ & $\begin{array}{l}\text { Water } \\
\text { use }\end{array}$ & $\begin{array}{l}\text { Geo- } \\
\text { hydro- } \\
\text { logic } \\
\text { unit }\end{array}$ & $\begin{array}{l}\text { Water } \\
\text { level } \\
\text { (feet) }\end{array}$ & Date & $\begin{array}{l}\text { Hydraulic } \\
\text { conductivity } \\
\text { (feet per day) }\end{array}$ & Remarks \\
\hline 20N/03E-11Q03 & ACA896 & 471349 & 1222305 & 30 & 491 & $\mathbf{P}$ & Qc4 & $3.29 \mathrm{R}$ & $06-27-95$ & 110 & D \\
\hline $20 \mathrm{~N} / 03 \mathrm{E}-13 \mathrm{C} 02$ & ACA891 & 471337 & 1222215 & 12 & 153 & $\mathrm{H}$ & Qc2 & 0.42 & $05-16-95$ & 38 & $\mathrm{D}$ \\
\hline 20N/03E-13D02 & & 471329 & 1222219 & 10 & 105 & $\mathbf{H}$ & Qc2 & 4.81 & $07-04-95$ & -- & D \\
\hline $20 \mathrm{~N} / 03 \mathrm{E}-13 \mathrm{H} 05$ & ACA888 & 471321 & 1222137 & 20 & 78 & $\mathbf{H}$ & Qc2 & 1.86 & $06-14-95$ & -- & D \\
\hline $20 \mathrm{~N} / 03 \mathrm{E}-13 \mathrm{M} 01^{1}$ & & 471307 & 1222222 & 30 & 275 & Q & Qc3 & -- & -- & 21 & \\
\hline 20N/03E-14A01 & & 471340 & 1222245 & 15 & 80 & $\mathrm{H}$ & -- & -- & -- & -- & \\
\hline 20N/03E-14A02 & & 471339 & 1222248 & 18 & 24.4 & $\mathrm{U}$ & Qc2 & 3.1 & $01-23-84$ & $-\sim$ & $\mathrm{D}$ \\
\hline 20N/03E-14B01 & ACA897 & 471330 & 1222303 & 185 & 145 & H & $\mathrm{Qc1}$ & 103.58 & $06-27-95$ & -- & $\mathrm{D}, \mathrm{W}$ \\
\hline $20 \mathrm{~N} / 03 \mathrm{E}-14 \mathrm{C} 02$ & & 471340 & 1222329 & 20 & 38 & $\mathrm{H}$ & Qc2 & -- & -- & -- & D \\
\hline 20N/03E-14F01 & ACH549 & 471322 & 1222328 & 200 & 133 & $\mathrm{U}$ & Qc1 & $117 .^{*}$ & $06-25-82$ & 77 & $\mathrm{D}$ \\
\hline 20N/03E-14G01 & & 471325 & 1222255 & 100 & 73 & $\mathrm{U}$ & Qc1 & 18.60 & $07-07-95$ & 10 & $\mathrm{D}$ \\
\hline $20 \mathrm{~N} / 03 \mathrm{E}-14 \mathrm{H} 01 \mathrm{~S}$ & & 471320 & 1222252 & 90 & -- & $\mathrm{P}$ & Qc1 & - & -- & -- & $\mathrm{I}, \mathrm{M}, \mathrm{T}, \mathrm{V}, \mathrm{P}$ \\
\hline 20N/03E-14R01 & & 471258 & 1222239 & 250 & 226 & $\mathrm{H}$ & Qc2 & 172.15 & $06-14-95$ & -- & D \\
\hline 20N/03E-15F01 & & 471326 & 1222434 & 247.5 & 653 & $\mathrm{P}$ & MLT & $183.0^{*}$ & $07-20-95$ & -- & D \\
\hline $20 \mathrm{~N} / 03 \mathrm{E}-17 \mathrm{G} 01$ & & 471325 & 1222656 & 370 & 55 & $\mathrm{U}$ & Qvt & 37.61 & $07-05-95$ & -- & $\mathrm{G}, \mathrm{W}$ \\
\hline 20N/03E-20K01 & & 471222 & 1222702 & 350 & 17.5 & $\mathrm{U}$ & Qvt & $\mathrm{D}$ & $06-29-88$ & -- & $\mathrm{G}$ \\
\hline 20N/03E-20P01 & ATT712 & 471159 & 1222714 & 315 & 117 & $\mathrm{U}$ & Qc1 & $89.98 *$ & $06-30-95$ & -- & $\mathrm{G}, \mathrm{W}, \mathrm{I}, \mathrm{M}, \mathrm{T}, \mathrm{V}, \mathrm{P}, \mathrm{R}, \mathrm{C}$ \\
\hline $20 \mathrm{~N} / 03 \mathrm{E}-20 \mathrm{P} 02$ & & 471159 & 1222714 & 315 & 254 & $U$ & Qc2 & $119.33 *$ & $06-30-95$ & -- & $\mathrm{G}, \mathrm{W}, \mathrm{I}, \mathrm{R}, \mathrm{C}$ \\
\hline $20 \mathrm{~N} / 03 \mathrm{E}-21 \mathrm{C} 01$ & & 471241 & 1222553 & 355 & 235 & I & Qc2 & $152.06 \mathrm{~T}$ & $06-02-95$ & 19 & $\mathrm{D}$ \\
\hline $20 \mathrm{~N} / 03 \mathrm{E}-22 \mathrm{~B} 01$ & & 471238 & 1222421 & 320 & 94 & $\mathrm{U}$ & Qvr & $100 .^{*}$ & $04-25-40$ & -- & \\
\hline 20N/03E-23D01S & & 471245 & 1222336 & 225 & -- & $\mathrm{U}$ & Qvr & -- & -- & -- & \\
\hline 20N/03E-23H01 & ACA613 & 471227 & 1222251 & 380 & 254 & $\mathrm{U}$ & Qc2 & 219.73 & $06-29-95$ & 7.1 & D \\
\hline 20N/03E-24A01 & & 471238 & 1222135 & 25 & 59 & $\mathrm{H}$ & Qc1 & $12.2^{*}$ & $04-24-92$ & - & $\mathrm{D}$ \\
\hline 20N/03E-24B01S & & 471246 & 1222157 & 170 & -- & $\mathrm{H}$ & Qc1 & -- & -- & -- & I,M,T,V,P \\
\hline $20 \mathrm{~N} / 03 \mathrm{E}-24 \mathrm{~B} 03 \mathrm{~S}$ & & 471247 & 1222156 & 170 & -- & $\mathrm{U}$ & Qc1 & -- & -- & -- & \\
\hline $20 \mathrm{~N} / 03 \mathrm{E}-24 \mathrm{~J} 01 \mathrm{~S}$ & & 471221 & 1222133 & 160 & -- & $\mathrm{U}$ & Qc1 & -- & -- & -- & \\
\hline $20 \mathrm{~N} / 03 \mathrm{E}-25 \mathrm{~A} 01 \mathrm{~S}$ & & 471153 & 1222128 & 160 & -- & $\mathrm{U}$ & Qc1 & -- & -- & -- & \\
\hline $20 \mathrm{~N} / 03 \mathrm{E}-25 \mathrm{CO} 1$ & ACA900 & 471144 & 1222218 & 360 & 214 & $\mathrm{P}$ & Qc2 & $162.96^{*}$ & $03-23-60$ & $8500^{a}$ & $\mathrm{D}$ \\
\hline $20 \mathrm{~N} / 03 \mathrm{E}-25 \mathrm{CO} 2$ & ACA799 & 471145 & 1222218 & 360 & 267 & $\mathrm{P}$ & Qc2 & $159.5^{*}$ & $09-26-60$ & 9.7 & $\mathrm{D}$ \\
\hline 20N/03E-25N01D1 & & 471106 & 1222222 & 430 & 258 & $\mathrm{H}$ & Qc2 & -- & -- & -- & I \\
\hline 20N/03E-26H01 & & 471134 & 1222249 & 425 & 188 & $S$ & Qc1 & $185 .^{*}$ & $-\cdots-40$ & -- & \\
\hline 20N/03E-26K01 & & 471128 & 1222315 & 410 & 28 & $\mathrm{U}$ & Qvt & 18.19 & $05-30-95$ & -- & $\mathrm{D}$ \\
\hline $20 \mathrm{~N} / 03 \mathrm{E}-28 \mathrm{~F} 02$ & & 471131 & 1222556 & 400 & 35 & $\mathrm{U}$ & Qvt & $24.18^{*}$ & $01-17-95$ & -- & $\mathrm{G}$ \\
\hline 20N/03E-28J01 & & 471133 & 1222508 & 420 & 35 & $\mathrm{U}$ & Qvt & 31.65 & $05-31-95$ & -- & G \\
\hline 20N/03E-30R01 & & 471107 & 1222802 & 300 & 30 & $\mathrm{U}$ & MLT & 22.80 & $06-02-95$ & -- & $\mathrm{G}, \mathrm{X}$ \\
\hline
\end{tabular}


Appendix 1.--Physical and hydrologic data for the wells and springs in the Tacoma-Puyallup area, Washington--Continued

\begin{tabular}{|c|c|c|c|c|c|c|c|c|c|c|c|c|}
\hline $\begin{array}{l}\text { Local well } \\
\text { number }\end{array}$ & $\begin{array}{l}\text { Tag } \\
\text { number }\end{array}$ & Latitude & Longitude & $\begin{array}{l}\text { Land } \\
\text { surface } \\
\text { altitude } \\
\text { (feet) }\end{array}$ & $\begin{array}{l}\text { Well } \\
\text { depth } \\
\text { (feet) }\end{array}$ & $\begin{array}{l}\text { Water } \\
\text { use }\end{array}$ & $\begin{array}{l}\text { Geo- } \\
\text { hydro- } \\
\text { logic } \\
\text { unit }\end{array}$ & $\begin{array}{l}\text { Water } \\
\text { level } \\
\text { (feet) }\end{array}$ & & Date & $\begin{array}{l}\text { Hydraulic } \\
\text { conductivity } \\
\text { (feet per day) }\end{array}$ & Remarks \\
\hline 20N/03E-31A01 & & 471055 & 1222756 & 300 & 18 & $\mathrm{H}$ & Qvr & $15.5^{*}$ & & $10-04-40$ & -- & $\mathrm{D}$ \\
\hline $20 \mathrm{~N} / 03 \mathrm{E}-32 \mathrm{D} 01$ & & 471053 & 1222738 & 300 & 15.7 & $\mathrm{U}$ & Qvr & $8.29 *$ & & $04-22-40$ & -- & $\mathrm{D}, \mathrm{X}$ \\
\hline $20 \mathrm{~N} / 03 \mathrm{E}-32 \mathrm{D} 02$ & & 471100 & 1222734 & 300 & 80 & $\mathrm{H}$ & Qc1 & $50.2 *$ & & $01-24-40$ & -- & \\
\hline 20N/03E-32D04 & & 471103 & 1222738 & 300 & 114 & $\mathrm{U}$ & Qc1 & $75 *^{*}$ & & $12-01-40$ & -- & $\mathrm{D}$ \\
\hline 20N/03E-34E01 & & 471049 & 1222453 & 415 & 19.8 & $\mathrm{U}$ & Qvt & 4.34 & & $06-06-95$ & -- & W \\
\hline $20 \mathrm{~N} / 03 \mathrm{E}-34 \mathrm{~L} 01$ & & 471034 & 1222447 & 415 & 396 & $\mathrm{P}$ & $\mathrm{Qc1}$ & $165 *^{*}$ & & $02-28-51$ & $3,600 .^{a}$ & $\mathrm{D}, \mathrm{X}$ \\
\hline 20N/03E-34L02 & & 471034 & 1222449 & 415 & 215 & $\mathrm{P}$ & Qc1 & 184.93 & $\mathrm{P}$ & $05-15-95$ & 2,500 & $\mathrm{D}, \mathrm{X}$ \\
\hline 20N/03E-34N01 & & 471022 & 1222509 & 385 & 223 & $\mathrm{H}$ & $\mathrm{Qc2}$ & 156.25 & $\mathrm{P}$ & $05-31-95$ & 23 & D \\
\hline $20 \mathrm{~N} / 03 \mathrm{E}-35 \mathrm{C} 01$ & & 471102 & 1222331 & 410 & 315.6 & $\mathrm{P}$ & Qc2 & -- & & -- & -- & $\mathrm{G}$ \\
\hline 20N/03E-35F01 & & 471050 & 1222333 & 405 & 18 & $\mathrm{U}$ & Qvt & 2.04 & & $05-30-95$ & -- & $\mathrm{D}, \mathrm{X}$ \\
\hline 20N/03E-35F02 & & 471049 & 1222329 & 410 & 288 & $\mathrm{H}$ & $\mathrm{Q} c 2$ & 206.21 & & $05-30-95$ & -- & \\
\hline 20N/03E-35L01 & & 471027 & 1222324 & 420 & 187 & $\mathrm{H}$ & Qc1 & $170 . *$ & & $09-01-53$ & -- & D \\
\hline 20N/03E-35L02 & & 471025 & 1222327 & 410 & 16 & $S$ & Qvt & 6.14 & & $05-30-95$ & -- & W \\
\hline 20N/03E-35R01 & & 471013 & 1222242 & 450 & 315 & $\mathrm{U}$ & MLT & $164 *$ & & $10-01-52$ & -- & $\mathrm{D}$ \\
\hline 20N/03E-36D01 & & 471103 & 1222236 & 415 & 34.2 & $\mathrm{U}$ & Qvt & 3.41 & & $03-11-60$ & -- & \\
\hline 20N/03E-36F01 & & 471050 & 1222202 & 390 & 372 & $U$ & Qc2 & -- & & -- & $4.8^{\mathrm{a}}$ & $\mathrm{D}, \mathrm{X}$ \\
\hline 20N/03E-36P01 & ABS 150 & 471021 & 1222206 & 428 & 210 & $\mathrm{P}$ & Qc2 & $\mathrm{P}$ & & $06-26-95$ & 2,400 & $\mathrm{D}$ \\
\hline 20N/04E-18M01 & & 471313 & 1222111 & 10 & 253 & $\mathrm{H}$ & -- & $5 . *$ & & $03-21-60$ & -- & \\
\hline 20N/04E-18M03 & & 471303 & 1222114 & 15 & 156 & $\mathrm{U}$ & Qc2 & $0 *^{*}$ & & $09-23-82$ & 11 & $\mathrm{D}$ \\
\hline 20N/04E-18Q01D2 & & 471250 & 1222034 & 20 & 328.33 & $\mathrm{U}$ & Qc3 & -2.42 & $\mathrm{~F}$ & $08-05-87$ & 550 & $\mathrm{D}$ \\
\hline 20N/04E-19B01 & & 471248 & 1222029 & 20 & 97 & $\mathrm{H}$ & Qc2 & 63.90 & $\mathrm{R}$ & $05-15-95$ & -- & \\
\hline 20N/04E-19G01 & ACA617 & 471225 & 1222030 & 25 & 58 & I & Qc1 & $5 . *$ & & $02-23-79$ & 14 & $\mathrm{D}, \mathrm{I}, \mathrm{M}, \mathrm{T}, \mathrm{V}, \mathrm{P}$ \\
\hline 20N/04E-19K01 & ACA610 & 471215 & 1222035 & 20 & 818 & $\mathrm{Z}$ & - & -5.08 & $\mathbf{F}$ & $09-09-88$ & 70 & D \\
\hline 20N/04E-19K02 & & 471216 & 1222036 & 20 & 915 & $\mathrm{U}$ & - & $\mathrm{F}$ & & $09-25-90$ & 34 & D \\
\hline 20N/04E-19Q01 & & 471202 & 1222043 & 25 & 118 & $\mathbf{H}$ & Qc2 & $\mathrm{F}$ & & $06-06-95$ & -- & D \\
\hline 20N/04E-20D04D1 & & 471236 & 1222009 & 30 & 390 & $\mathbf{P}$ & Qc3 & -0.88 & $\mathrm{~F}$ & $03-21-96$ & 24 & $\mathrm{D}$ \\
\hline 20N/04E-20D06 & & 471237 & 1222009 & 30 & 298 & $\mathbf{P}$ & Qc3 & -4.00 & $\mathbf{F}$ & $03-21-96$ & -- & $\mathrm{D}$ \\
\hline 20N/04E-20E04 & & 471234 & 1221954 & 30 & 56 & $\mathbf{P}$ & Qf1 & $15 .^{*}$ & & $05-19-83$ & -- & $\mathrm{D}, \mathrm{X}$ \\
\hline 20N/04E-20E06 & AAC 903 & 471225 & 1221948 & 25 & 115 & $S$ & Qc2 & 7.40 & & $05-18-95$ & -- & $\mathrm{D}, \mathrm{X}, \mathrm{I}, \mathrm{M}, \mathrm{V}$ \\
\hline 20N/04E-20K01 & & 471211 & 1221925 & 25 & 267 & -- & Qc3 & $\mathrm{F}$ & & $03-24-53$ & -- & D \\
\hline $20 \mathrm{~N} / 04 \mathrm{E}-20 \mathrm{~N} 01$ & ACA624 & 471201 & 1222003 & 30 & 90 & $\mathbf{H}$ & Qc2 & -0.8 & $\mathrm{~F}$ & $06-29-95$ & 540 & $\mathrm{I}, \mathrm{M}$ \\
\hline 20N/04E-20N05 & & 471203 & 1221956 & 30 & 184 & $\mathrm{P}$ & Qf2 & $\mathbf{F}$ & & $05-04-84$ & 58 & $\mathrm{D}, \mathrm{X}$ \\
\hline 20N/04E-20P02 & & 471204 & 1221929 & 25 & 92 & $\mathrm{U}$ & Qc2 & 5.70 & & $06-06-95$ & 18 & $\mathrm{D}, \mathrm{W}$ \\
\hline $20 \mathrm{~N} / 04 \mathrm{E}-21 \mathrm{~A} 01$ & & 471244 & 1221739 & 40 & 40 & $\mathrm{D}$ & - & -- & & - & -- & D \\
\hline 20N/04E-21P01 & & 471204 & 1221821 & 30 & 230 & $\mathbf{U}$ & Qc3 & $\mathrm{F}$ & & $04-12-60$ & -- & D \\
\hline
\end{tabular}


Appendix 1.--Physical and hydrologic data for the wells and springs in the Tacoma-Puyallup area, Washington--Continued

\begin{tabular}{|c|c|c|c|c|c|c|c|c|c|c|c|}
\hline $\begin{array}{l}\text { Local well } \\
\text { number }\end{array}$ & $\begin{array}{l}\text { Tag } \\
\text { number }\end{array}$ & Latitude & Longitude & $\begin{array}{l}\text { Land } \\
\text { surface } \\
\text { altitude } \\
\text { (feet) }\end{array}$ & $\begin{array}{l}\text { Well } \\
\text { depth } \\
\text { (feet) }\end{array}$ & $\begin{array}{l}\text { Water } \\
\text { use }\end{array}$ & $\begin{array}{l}\text { Geo- } \\
\text { hydro- } \\
\text { logic } \\
\text { unit }\end{array}$ & $\begin{array}{l}\text { Water } \\
\text { level } \\
\text { (feet) }\end{array}$ & Date & $\begin{array}{l}\text { Hydraulic } \\
\text { conductivity } \\
\text { (feet per day) }\end{array}$ & Remarks \\
\hline 20N/04E-25N01 & & 471107 & 1221454 & 70 & 113 & $\mathrm{H}$ & Qc2 & 7.69 & $06-08-95$ & 250 & $\mathrm{D}$ \\
\hline 20N/04E-25P01 & & 471106 & 1221429 & 70 & 92 & $\mathbf{U}$ & $\mathrm{Qc2}$ & $8 . *$ & $04-24-53$ & 170 & $\mathrm{D}, \mathrm{X}$ \\
\hline 20N/04E-25Q01 & ACA626 & 471112 & 1221417 & 60 & 105 & I & Qc2 & $\mathrm{F}$ & $07-01-95$ & 170 & $\mathrm{D}, \mathrm{X}$ \\
\hline $20 \mathrm{~N} / 04 \mathrm{E}-26 \mathrm{E} 01$ & & 471133 & 1221605 & 45 & 169 & I & $\mathrm{Qc2}$ & $\mathrm{F}$ & $05-16-85$ & 2,000 & $\mathrm{D}$ \\
\hline 20N/04E-26M01 & & 471130 & 1221604 & 40 & 20 & $\mathrm{U}$ & Qc1 & $6.97 *$ & $03-20-95$ & -- & G \\
\hline $20 \mathrm{~N} / 04 \mathrm{E}-26 \mathrm{M} 02$ & & 471130 & 1221605 & 40 & 20 & $\mathbf{U}$ & Qc1 & $7.35^{*}$ & $03-20-95$ & -- & G \\
\hline 20N/04E-26Q01 & $\mathrm{ACA} 609$ & 471116 & 1221526 & 65 & 118 & $\mathrm{H}$ & Qc2 & 4.53 & $06-17-95$ & 300 & $\mathrm{D}$ \\
\hline $20 \mathrm{~N} / 04 \mathrm{E}-27 \mathrm{H} 01$ & & 471133 & 1221619 & 40 & 190 & I & Qc3 & F & $06-07-95$ & 620 & $\mathrm{D}, \mathrm{X}$ \\
\hline 20N/04E-27J01 & & 471124 & 1221623 & 55 & 233 & $\mathrm{~N}$ & Qc3 & $\mathrm{F}$ & $06-07-95$ & 210 & $\mathrm{D}, \mathrm{X}$ \\
\hline $20 \mathrm{~N} / 04 \mathrm{E}-27 \mathrm{~L} 01$ & & 471127 & 1221711 & 45 & 285 & $\mathrm{U}$ & Qc3 & $F$ & $06-29-95$ & $64^{a}$ & $\mathrm{D}$ \\
\hline 20N/04E-27Q01 & & 471106 & 1221636 & 55 & 328 & $\mathrm{C}$ & Qc3 & -11.2 & $03-14-53$ & -- & \\
\hline $20 \mathrm{~N} / 04 \mathrm{E}-28 \mathrm{E} 01$ & & 471137 & 1221833 & 40 & 82 & $U$ & Qf1 & 9.* & $10-01-41$ & -- & $\mathrm{D}$ \\
\hline $20 \mathrm{~N} / 04 \mathrm{E}-28 \mathrm{H} 01$ & & 471137 & 1221749 & 40 & 200 & $\mathrm{U}$ & Qf2 & $\mathbf{F}$ & $04-11-60$ & -- & $\cdot$ \\
\hline 20N/04E-28H04 & & 471131 & 1221739 & 40 & 253 & $\mathrm{~N}$ & Qc3 & $\mathbf{F}$ & $04-08-60$ & - & $\mathrm{D}$ \\
\hline $20 \mathrm{~N} / 04 \mathrm{E}-28 \mathrm{H} 05$ & & 471143 & 1221734 & 40 & 20 & $\mathbf{U}$ & Qc1 & -- & -- & -- & G \\
\hline $20 \mathrm{~N} / 04 \mathrm{E}-28 \mathrm{H} 06$ & & 471131 & 1221741 & 40 & 252 & $\mathbf{U}$ & Qc3 & -- & -. & 350 & $\mathrm{D}$ \\
\hline 20N/04E-29D03 & & 471148 & 1221949 & 30 & 362 & $\mathbf{P}$ & -- & $\mathbf{F}$ & $06-09-95$ & 2,000 & $\mathrm{D}, \mathrm{X}$ \\
\hline $20 \mathrm{~N} / 04 \mathrm{E}-29 \mathrm{~F} 01$ & & 471140 & 1221930 & 30 & 265 & $\mathrm{U}$ & -- & F & $03-28-46$ & 130 & $\mathrm{D}$ \\
\hline 20N/04E-29P03 & ACA614 & 471116 & 1221931 & 50 & 119 & $\mathbf{H}$ & Qc2 & $-0.02 \mathrm{~F}$ & $06-09-95$ & 12 & $\mathrm{D}$ \\
\hline 20N/04E-30C02 & ACA605 & 471150 & 1222049 & 50 & 115 & $\mathbf{H}$ & Qc2 & 9.91 & $06-20-95$ & 55 & $\mathrm{D}$ \\
\hline $20 \mathrm{~N} / 04 \mathrm{E}-30 \mathrm{C} 03$ & & 471154 & 1222049 & 30 & 40 & $\mathrm{H}$ & Qc1 & 4.* & $07-30-82$ & -- & $\mathrm{D}$ \\
\hline $20 \mathrm{~N} / 04 \mathrm{E}-30 \mathrm{~F} 01$ & & 471135 & 1222046 & 230 & 195 & $\mathrm{H}$ & Qc2 & 145.69 & $06-13-95$ & -- & $\mathrm{D}$ \\
\hline 20N/04E-30G02 & & 471141 & 1222032 & 60 & 78.5 & $\mathrm{H}$ & Qc1 & 9.05 & $06-14-95$ & -- & $\mathrm{D}, \mathrm{I}, \mathrm{M}, \mathrm{T}, \mathrm{V}, \mathrm{P}$ \\
\hline 20N/04E-30H01 & & 471132 & 1222009 & 40 & 332 & $\mathrm{Q}$ & -- & F & $03-26-95$ & 57 & $\mathrm{D}$ \\
\hline $20 \mathrm{~N} / 04 \mathrm{E}-30 \mathrm{~J} 01^{1}$ & & 471125 & 1222017 & 160 & 95 & $\mathbf{H}$ & Qc1 & 62.6 & $03-23-60$ & 51 & \\
\hline $20 \mathrm{~N} / 04 \mathrm{E}-30 \mathrm{~L} 02$ & & 471128 & 1222046 & 320 & 270 & $\mathbf{U}$ & Qc3 & 228.32 & $10-08-85$ & 150 & $\mathrm{D}$ \\
\hline $20 \mathrm{~N} / 04 \mathrm{E}-30 \mathrm{~L} 03 \mathrm{~S}$ & & 471129 & 1222059 & 230 & -- & $\mathrm{H}$ & Qc1 & -- & -- & -- & \\
\hline $20 \mathrm{~N} / 04 \mathrm{E}-30 \mathrm{P02}$ & ACA618 & 471104 & 1222048 & 390 & 450 & $\mathbf{P}$ & Qc3 & $275.50 \mathrm{P}$ & $06-09-95$ & 7.3 & $\mathrm{D}, \mathrm{W}$ \\
\hline 20N/04E-31B01 & & 471054 & 1222038 & 380 & 56 & $\mathrm{H}$ & Qvt & 34.50 & $05-22-95$ & -- & W,I,M \\
\hline 20N/04E-31F02 & ACA608 & 471042 & 1222057 & 400 & 180 & $\mathbf{H}$ & Qf1 & 125.00 & $05-23-95$ & 10 & $\mathrm{D}, \mathrm{X}, \mathrm{I}, \mathrm{M}$ \\
\hline 20N/04E-31G01 & ACA 620 & 471050 & 1222030 & 350 & 126 & $\mathbf{H}$ & Qc1 & 69.29 & $04-07-60$ & $13 .^{a}$ & D \\
\hline 20N/04E-31H05 & ACA603 & 471039 & 1222017 & 380 & 192 & $\mathbf{H}$ & Qc1 & 139.56 & $06-17-95$ & 28 & $\mathrm{D}, \mathrm{X}$ \\
\hline $20 \mathrm{~N} / 04 \mathrm{E}-32 \mathrm{E} 01$ & & 471045 & 1221954 & 265 & 16.5 & $\mathbf{H}$ & Qvr & 5.29 & $04-08-60$ & -- & $\mathrm{D}$ \\
\hline 20N/04E-32E02 & & 471043 & 1221955 & 270 & 295 & $\mathbf{H}$ & Qc3 & 178.40 & $05-23-95$ & 4.1 & $\mathrm{D}, \mathrm{X}$ \\
\hline 20N/04E-32H01 & & 471038 & 1221851 & 31.7 & 170 & $\mathbf{U}$ & Qc2 & $\mathrm{F}$ & $12-20-56$ & 140 & $\mathrm{D}$ \\
\hline
\end{tabular}


Appendix 1.--Physical and hydrologic data for the wells and springs in the Tacoma-Puyallup area, Washington--Continued

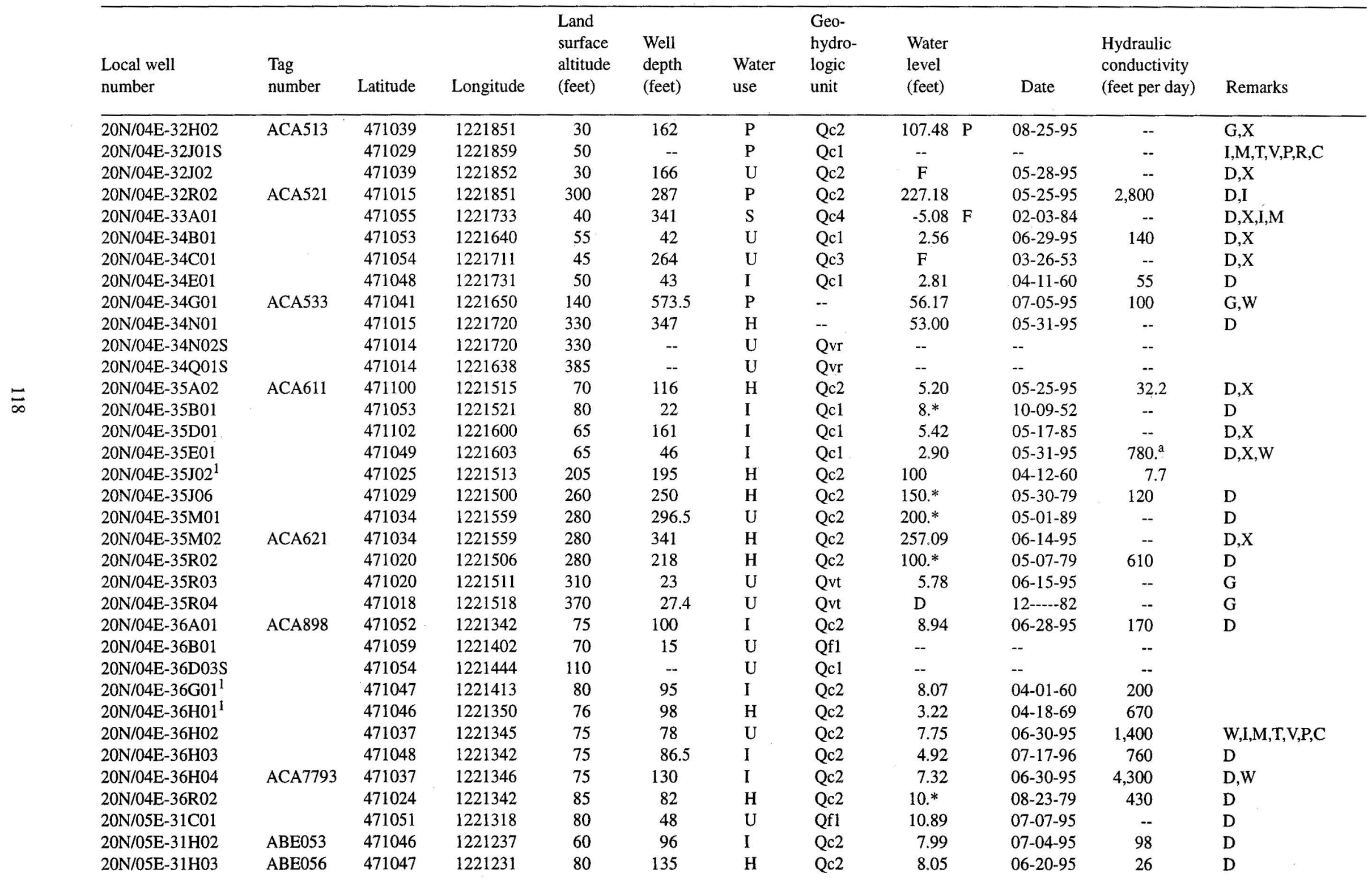


Appendix 1.--Physical and hydrologic data for the wells and springs in the Tacoma-Puyallup area, Washington--Continued

\begin{tabular}{|c|c|c|c|c|c|c|c|c|c|c|c|}
\hline $\begin{array}{l}\text { Local well } \\
\text { number }\end{array}$ & $\begin{array}{l}\text { Tag } \\
\text { number }\end{array}$ & Latitude & Longitude & $\begin{array}{l}\text { Land } \\
\text { surface } \\
\text { altitude } \\
\text { (feet) }\end{array}$ & $\begin{array}{l}\text { Well } \\
\text { depth } \\
\text { (feet) }\end{array}$ & $\begin{array}{l}\text { Water } \\
\text { use }\end{array}$ & $\begin{array}{l}\text { Geo- } \\
\text { hydro- } \\
\text { logic } \\
\text { unit }\end{array}$ & $\begin{array}{l}\text { Water } \\
\text { level } \\
\text { (feet) }\end{array}$ & Date & $\begin{array}{l}\text { Hydraulic } \\
\text { conductivity } \\
\text { (feet per day) }\end{array}$ & Remarks \\
\hline $21 \mathrm{~N} / 02 \mathrm{E}-23 \mathrm{~A} 01$ & & 471759 & 1223032 & 113.99 & 103.5 & $\mathrm{U}$ & Qc1 & $92.98 *$ & $09-16-94$ &.- & $\mathrm{G}$ \\
\hline $21 \mathrm{~N} / 02 \mathrm{E}-23 \mathrm{~A} 02$ & & 471756 & 1223025 & 55.95 & 69 & $\mathrm{U}$ & Qc1 & 31.39 & $06-05-91$ & -- & G \\
\hline $21 \mathrm{~N} / 02 \mathrm{E}-23 \mathrm{G} 01$ & & 471746 & 1223041 & 145 & 423 & $\mathrm{U}$ & -- & -- & -- & -- & $\mathrm{D}$ \\
\hline $21 \mathrm{~N} / 02 \mathrm{E}-23 \mathrm{H} 03$ & & 471749 & 1223027 & 144.86 & 158.5 & $\mathrm{U}$ & Qc1 & $121.56^{*}$ & $09-16-94$ & -- & G \\
\hline 21N/02E-24D01 & & 471759 & 1223012 & 24.97 & 45 & $\mathrm{U}$ & Qc1 & $13.21 *$ & $09-18-94$ & -- & $\mathrm{G}$ \\
\hline $21 \mathrm{~N} / 02 \mathrm{E}-25 \mathrm{~B} 01 \mathrm{~S}$ & & 471657 & 1222938 & 120 & -- & $\mathrm{U}$ & -- & -- & -- & -- & \\
\hline 21N/02E-24E01 & & 471752 & 1223001 & 22.88 & 40 & $\mathrm{U}$ & Qc1 & $8.86^{*}$ & $05-15-91$ & -- & $\mathrm{G}$ \\
\hline $21 \mathrm{~N} / 02 \mathrm{E}-34 \mathrm{E} 01 \mathrm{~S}$ & & 471556 & 1223230 & 20 & -- & $\mathrm{U}$ & Qc1 & -- & -- & $\cdots$ & \\
\hline $21 \mathrm{~N} / 02 \mathrm{E}-34 \mathrm{~F} 01 \mathrm{~S}$ & & 471600 & 1223218 & 175 & -- & $\mathrm{U}$ & Qc1 & -- & -- & -- & \\
\hline $21 \mathrm{~N} / 02 \mathrm{E}-34 \mathrm{~F} 02 \mathrm{~S}$ & & 471558 & 1223215 & 175 & -- & $\mathrm{U}$ & Qvr & -- &.- & -- & \\
\hline $21 \mathrm{~N} / 02 \mathrm{E}-34 \mathrm{~F} 03 \mathrm{~S}$ & & 471601 & 1223215 & 175 & -- & $\mathrm{U}$ & Qvr & -- & -- & $\ldots$ & \\
\hline $21 \mathrm{~N} / 02 \mathrm{E}-34 \mathrm{M} 01$ & & 471555 & 1223244 & 0 & 240 & $\mathrm{U}$ & -- & -- & -- & -- & $G$ \\
\hline $21 \mathrm{~N} / 02 \mathrm{E}-34 \mathrm{~N} 02$ & & 471541 & 1223243 & 10 & 428 & $\mathrm{H}$ & Qc4 & $4.1^{*}$ & $04-26-62$ & $9.7^{\mathrm{a}}$ & $\mathrm{D}$ \\
\hline $21 \mathrm{~N} / 03 \mathrm{E}-30 \mathrm{M} 01 \mathrm{~S}$ & & 471644 & 1222841 & 45 & -- & $\mathrm{U}$ & Qc1 & -- & $--\quad \quad$ & -- & \\
\hline $21 \mathrm{~N} / 03 \mathrm{E}-30 \mathrm{M} 02 \mathrm{~S}$ & & 471645 & 1222839 & 30 & -- & $\mathrm{U}$ & Qc1 & - & -- & -- & \\
\hline 21N/03E-31M01 & & 471549 & 1222843 & 345 & 925 & A & -- & $307 . *$ & $12-01-64$ & -- & $\mathrm{D}$ \\
\hline 21N/03E-32K01 & & 471546 & 1222656 & 280 & 80 & $\mathrm{U}$ & Qc1 & -. & -- & -- & $\mathrm{G}$ \\
\hline
\end{tabular}

1 Wells not inventoried during this project, used for hydraulic conductivity data only.

2 Spring located outside study area not on figure 3. 
Appendix 2.--Drillers' lithologic logs of wells used in construction of hydrogeologic sections, in the Tacoma-Puyallup area, Washington [swl, static water level in feet below land surface; dd, drawdown in feet; gpm, gallons per minute; ft, feet]

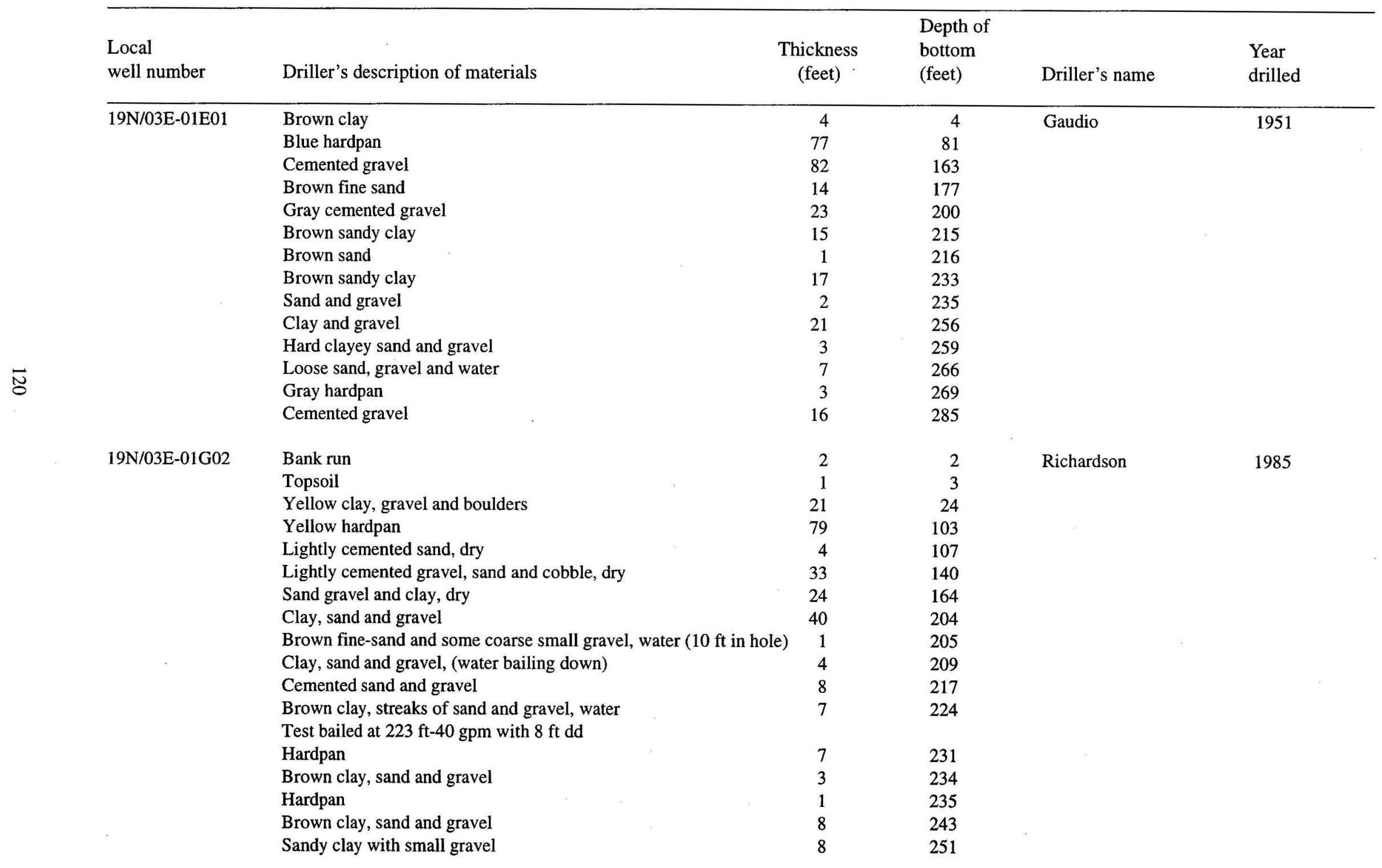


Appendix 2.--Drillers' lithologic logs of wells used in construction of hydrogeologic sections, in the Tacoma-Puyallup area, Washington--Continued

\begin{tabular}{|c|c|c|c|c|c|}
\hline $\begin{array}{l}\text { Local } \\
\text { well number }\end{array}$ & Driller's description of materials & $\begin{array}{l}\text { Thickness } \\
\text { (feet) }\end{array}$ & $\begin{array}{l}\text { Depth of } \\
\text { bottom } \\
\text { (feet) }\end{array}$ & Driller's name & $\begin{array}{l}\text { Year } \\
\text { drilled }\end{array}$ \\
\hline $\begin{array}{l}\text { 19N/03E-01G02-- } \\
\text { continued }\end{array}$ & $\begin{array}{l}\text { Clay, sand, gravel, yellow cobble } \\
\text { Yellow hardpan and boulders } \\
\text { Gray hardpan and boulders } \\
\text { Gray-green sticky clay } \\
\text { Gray hardpan } \\
\text { Clay, sand and gray gravel } \\
\text { Clay, sand, yellow gravel, } 412 \text { to } 416 \mathrm{ft} \text {, lots of boulders } \\
\text { Sandy yellow clay } \\
\text { Clay, sand, gravel and boulders } \\
\text { Clay, sand and yellow gravel } \\
\text { Hardpan } \\
\text { Hard clay, sand and brown gravel } \\
\text { Hardpan, boulder at } 549 \mathrm{ft} \\
\text { Blue clay with gravel } \\
\text { Blue clay, with sand and gravel } \\
\text { Clay sand and few small gravel with lenses of sticky blue clay } \\
\text { Gritty blue clay and lenses of multi-color clay }\end{array}$ & $\begin{array}{r}10 \\
21 \\
36 \\
12 \\
15 \\
10 \\
76 \\
18 \\
11 \\
9 \\
4 \\
20 \\
78 \\
9 \\
18 \\
3 \\
18\end{array}$ & $\begin{array}{l}261 \\
282 \\
318 \\
330 \\
345 \\
355 \\
431 \\
449 \\
460 \\
469 \\
473 \\
493 \\
571 \\
580 \\
598 \\
601 \\
619\end{array}$ & & \\
\hline $19 \mathrm{~N} / 03 \mathrm{E}-01 \mathrm{~J} 01$ & $\begin{array}{l}\text { Cemented blue gravel } \\
\text { Cemented yellow gravel } \\
\text { Cemented yellow gravel, streaks of sand } \\
\text { Sand } \\
\text { Cemented yellow gravel, streaks of sand } \\
\text { Sand and gravel } \\
\text { Cemented gravel } \\
\text { Hard sand and gravel } \\
\text { Gravel and clay } \\
\text { Yellow sandy clay } \\
\text { Yellow clay and coarse gravel } \\
\text { Yellow sandy clay } \\
\text { Yellow-blue cemented gravel } \\
\text { Blue-gray cemented gravel } \\
\text { Hard packed sand and gravel } \\
\text { Yellow cemented clay and gravel }\end{array}$ & $\begin{array}{r}56 \\
24 \\
84 \\
3 \\
34 \\
1 \\
9 \\
17 \\
20 \\
16 \\
21 \\
4 \\
17 \\
44 \\
12 \\
13\end{array}$ & $\begin{array}{r}56 \\
80 \\
164 \\
167 \\
201 \\
202 \\
211 \\
228 \\
248 \\
264 \\
285 \\
289 \\
306 \\
350 \\
362 \\
375\end{array}$ & Gaudio & 1950 \\
\hline
\end{tabular}


Appendix 2.--Drillers' lithologic logs of wells used in construction of hydrogeologic sections, in the Tacoma-Puyallup area, Washington--Continued

\begin{tabular}{|c|c|c|c|c|c|}
\hline $\begin{array}{l}\text { Local } \\
\text { well number }\end{array}$ & Driller's description of materials & $\begin{array}{l}\text { Thickness } \\
\text { (feet) }\end{array}$ & $\begin{array}{l}\text { Depth of } \\
\text { bottom } \\
\text { (feet) }\end{array}$ & Driller's name & $\begin{array}{l}\text { Year } \\
\text { drilled }\end{array}$ \\
\hline \multirow{2}{*}{$\begin{array}{l}\text { 19N/03E-01J01-- } \\
\text { continued }\end{array}$} & Yellow sandy clay & 12 & 387 & & \\
\hline & Cemented gravel & 20 & 407 & & \\
\hline \multirow[t]{19}{*}{ 19N/03E-03F02 } & Fill & 8 & 8 & Armstrong & 1985 \\
\hline & Brown claybound sand and gravel & 9 & 17 & & \\
\hline & Gray claybound sand and gravel & 20 & 37 & & \\
\hline & Blue-gray claybound sand and gravel & 59 & 96 & & \\
\hline & Brown claybound sand and gravel & 60 & 156 & & \\
\hline & Coarse sand and gravel, some water & 25 & 181 & & \\
\hline & Tighter sand and gravel, some water & 13 & 194 & & \\
\hline & Brown claybound sand and gravel & 10 & 204 & & \\
\hline & Gray to yellow-brown claybound sand and gravel & 20 & 224 & & \\
\hline & Sand, gravel and water & 5 & 229 & & \\
\hline & Brown claybound sand and gravel, some water $246-280 \mathrm{ft}$ & 53 & 282 & & \\
\hline & Sand, gravel and boulders & 2 & 284 & & \\
\hline & Gray claybound sand and gravel & 30 & 314 & & \\
\hline & Sand, gravel and water & 6 & 320 & & \\
\hline & Sand, gravel, boulders and water & 5 & 325 & & \\
\hline & Gray claybound sand and gravel, boulders at $350 \mathrm{ft}$ & 25 & 350 & & \\
\hline & Gray claybound sand and gravel & 6 & 356 & & \\
\hline & Sand, gravel, boulders and water & 18 & 374 & & \\
\hline & Gray claybound sand and gravel & 13 & 387 & & \\
\hline \multirow[t]{11}{*}{ 19N/03E-03F04 } & Gray clayey fill & 8 & 8 & Charon & 1993 \\
\hline & Gray clay, sand and gravel & 19 & 27 & & \\
\hline & Gravel, sand, silt, some clay & 16 & 43 & & \\
\hline & Silty sand and gravel in clay matrix & 127 & 170 & & \\
\hline & Brown sand, gravel, cobbles and water & 30 & 200 & & \\
\hline & Gray sand and gravel in clay matrix & 27 & 227 & & \\
\hline & Sand, gravel and water & 1 & 228 & & \\
\hline & Sand, gravel, gray-brown in silt matrix and minor water & 17 & 245 & & \\
\hline & Brown sandy clay & 7 & 252 & & \\
\hline & Brown sandy clay, gravel and some water & 5 & 257 & & \\
\hline & Brown sand and gravel with clay matrix & 63 & 320 & & \\
\hline
\end{tabular}


Appendix 2.--Drillers' lithologic logs of wells used in construction of hydrogeologic sections, in the Tacoma-Puyallup area, Washington--Continued

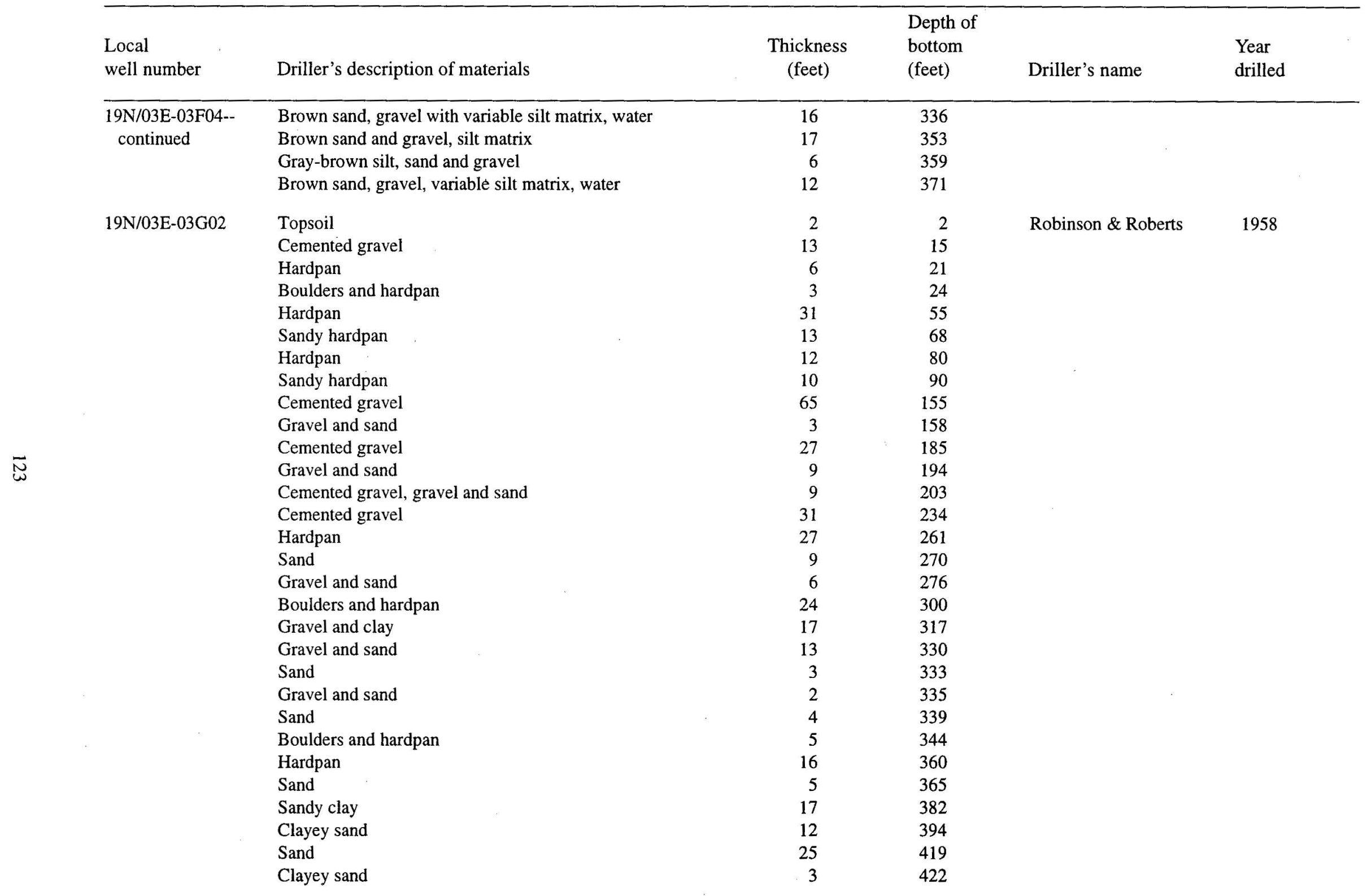


Appendix 2.--Drillers' lithologic logs of wells used in construction of hydrogeologic sections, in the Tacoma-Puyallup area, Washington--Continued

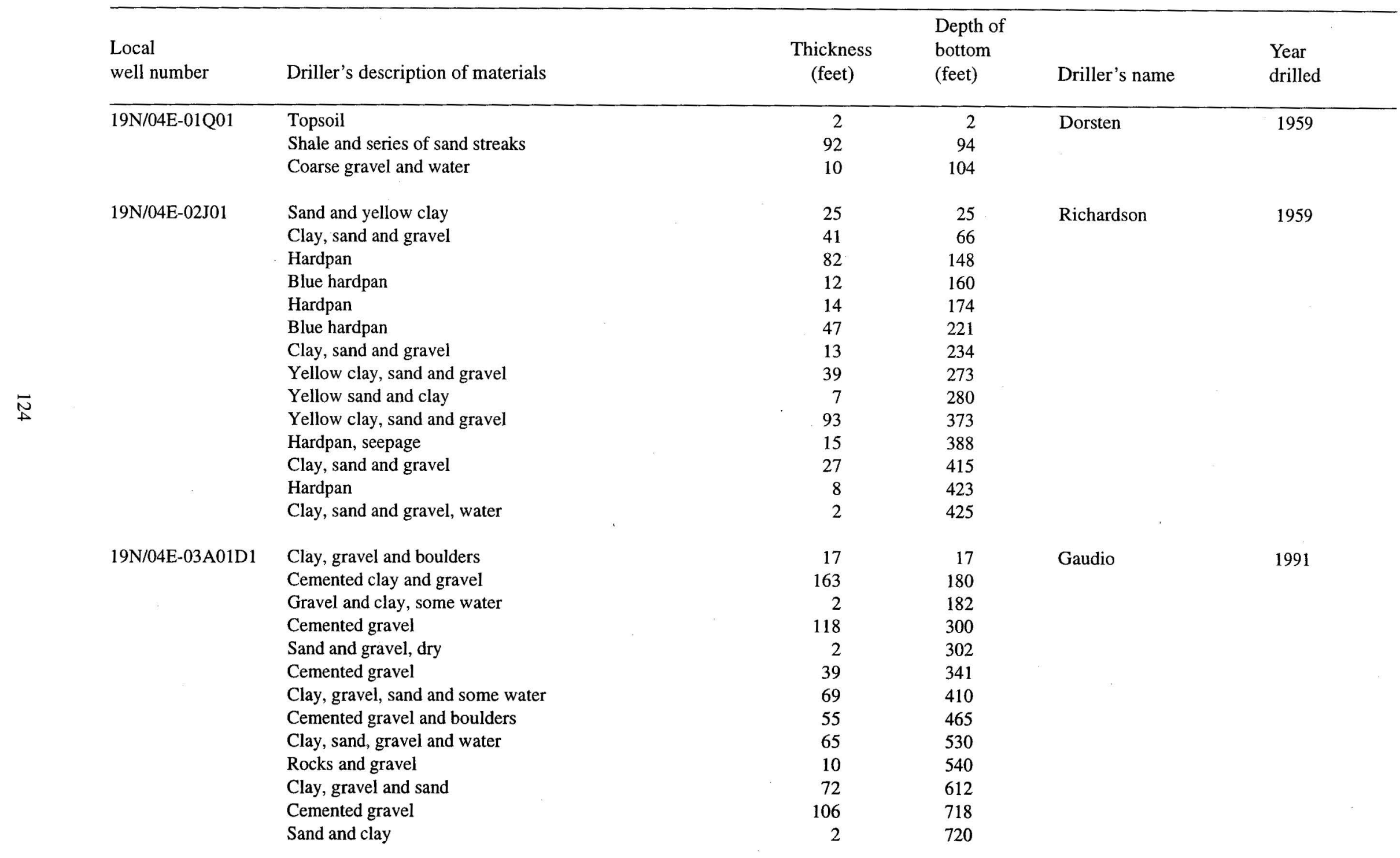


Appendix 2.--Drillers' lithologic logs of wells used in construction of hydrogeologic sections, in the Tacoma-Puyallup area, Washington--Continued

\begin{tabular}{|c|c|c|c|c|c|}
\hline $\begin{array}{l}\text { Local } \\
\text { well number }\end{array}$ & Driller's description of materials & $\begin{array}{l}\text { Thickness } \\
\text { (feet) }\end{array}$ & $\begin{array}{l}\text { Depth of } \\
\text { bottom } \\
\text { (feet) }\end{array}$ & Driller's name & $\begin{array}{l}\text { Year } \\
\text { drilled }\end{array}$ \\
\hline \multirow{9}{*}{$\begin{array}{l}\text { 19N/04E-03A01D1-- } \\
\text { continued }\end{array}$} & Sand and water & 14 & 734 & & \\
\hline & Sand, gravel and sandstone & 22 & 756 & & \\
\hline & Cemented gravel and water & 56 & 812 & & \\
\hline & Clay & 1 & 813 & & \\
\hline & Gravel, sand and water & 6 & 819 & & \\
\hline & Gravel and sand & 6 & 825 & & \\
\hline & Silt & 1 & 826 & & \\
\hline & Sand, gravel and clay & 1 & 827 & & \\
\hline & Clay & 20 & 847 & & \\
\hline \multirow[t]{5}{*}{ 19N/04E-03Q01 } & Brown fine to medium silty sand, little gravel, trace organics & 4 & 4 & Converse Consultants & 1982 \\
\hline & Gray-brown silty sand, little gravel, some cobbles to boulders & 15 & 19 & & \\
\hline & Gray-brown gravelly sand, little silt, trace of clay & 9 & 28 & & \\
\hline & $\begin{array}{l}\text { Gray-brown medium to coarse sand and gravel, some } \\
\text { weathered gravel }\end{array}$ & 10 & 38 & & \\
\hline & Brown fine to medium sand, trace coarse sand, gravel, trace silt & 6.5 & 44.5 & & \\
\hline \multirow[t]{17}{*}{ 19N/04E-03R01D2 } & Fill & 4 & 4 & Richardson & 1981 \\
\hline & Topsoil & 2 & 6 & & \\
\hline & Hardpan & 7 & 13 & & \\
\hline & Sandy Clay & 3 & 16 & & \\
\hline & Clay, sand and gravel, brown seepage & 4 & 20 & & \\
\hline & Brown sandy clay & 6 & 26 & & \\
\hline & Hardpan & 8 & 34 & & \\
\hline & Cemented gravel & 2 & 36 & & \\
\hline & Cemented sand and gravel & 21 & 57 & & \\
\hline & Sand and gravel, little clay & 9 & 66 & & \\
\hline & Cemented sand and gravel & 26 & 92 & & \\
\hline & Brown sand and gravel & 18 & 110 & & \\
\hline & Cemented sand and gravel & 17 & 127 & & \\
\hline & Brown sand and gravel & 94 & 221 & & \\
\hline & Sand, gravel, water bearing & 14 & 235 & & \\
\hline & Sand and gravel, little brown clay & 7 & 242 & & \\
\hline & Cemented sand and gravel & 32 & 274 & & \\
\hline
\end{tabular}


Appendix 2.--Drillers' lithologic logs of wells used in construction of hydrogeologic sections, in the Tacoma-Puyallup area, Washington--Continued

\begin{tabular}{|c|c|c|c|c|c|}
\hline $\begin{array}{l}\text { Local } \\
\text { well number }\end{array}$ & Driller's description of materials & $\begin{array}{l}\text { Thickness } \\
\text { (feet) }\end{array}$ & $\begin{array}{l}\text { Depth of } \\
\text { bottom } \\
\text { (feet) }\end{array}$ & Driller's name & $\begin{array}{l}\text { Year } \\
\text { drilled }\end{array}$ \\
\hline $\begin{array}{l}\text { 19N/04E-03R01D2-- } \\
\text { continued }\end{array}$ & $\begin{array}{l}\text { Brown cemented sand and gravel } \\
\text { Cemented sand and large dark rocks } \\
\text { Cemented sand and gravel } \\
\text { Sand and gravel, some brown clay } \\
\text { Cemented sand and gravel } \\
\text { Sandy clay some gravel } \\
\text { Sandy clay } \\
\text { Fine sand } \\
\text { Sand, gravel and water } \\
\text { Sand, gravel and brown clay } \\
\text { Brown sandy clay } \\
\text { Cemented sand and gravel } \\
\text { Sand, gravel and brown clay, water } \\
\text { Cemented sand and gravel } \\
\text { Gray sand, gravel and water } \\
\text { Sand, gravel and water } \\
\text { Sand, gravel and brown clay } \\
\text { Cemented sand and gravel, no water, bailing down } \\
\text { Cemented sand and gravel } \\
\text { Sand and gravel } \\
\text { Sand and gravel, } 90 \text { percent sand } \\
\text { Dirty sand and gravel } \\
\text { Light brown clay } \\
\text { Sand and gravel, water } \\
\text { Sand and gravel, large rocks, water } \\
\text { Dirty sand and gravel } \\
\text { Cemented sand and gravel } \\
\text { Brown clay some gravel } \\
\text { Sand, gravel and water } \\
\text { Sand and gravel, some cemented gravel } \\
\text { Sand and gravel, large rocks, water } \\
\text { Dirty sand and gravel, large rocks, water } \\
\text { Sand and gravel, brown clay } \\
\text { Brown clay, sand and gravel }\end{array}$ & $\begin{array}{r}26 \\
10 \\
16 \\
10 \\
54 \\
14 \\
12 \\
2 \\
7 \\
11 \\
5 \\
24 \\
5 \\
1 \\
8 \\
3 \\
2 \\
8 \\
15 \\
8 \\
14 \\
3 \\
20 \\
7 \\
16 \\
2 \\
1 \\
6 \\
9 \\
6 \\
4 \\
9 \\
7 \\
8\end{array}$ & $\begin{array}{l}300 \\
310 \\
326 \\
336 \\
390 \\
404 \\
416 \\
418 \\
425 \\
436 \\
441 \\
465 \\
470 \\
471 \\
479 \\
482 \\
484 \\
492 \\
507 \\
515 \\
529 \\
532 \\
552 \\
559 \\
575 \\
577 \\
578 \\
584 \\
593 \\
599 \\
603 \\
612 \\
619 \\
627\end{array}$ & 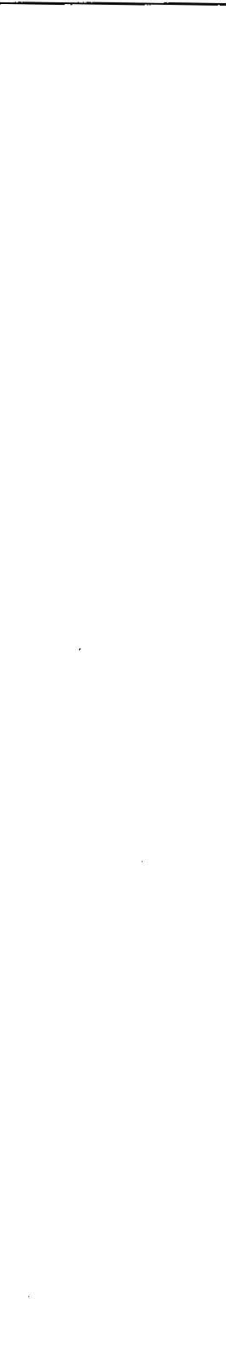 & . \\
\hline
\end{tabular}


Appendix 2.--Drillers' lithologic logs of wells used in construction of hydrogeologic sections, in the Tacoma-Puyallup area, Washington--Continued

\begin{tabular}{|c|c|c|c|c|c|}
\hline $\begin{array}{l}\text { Local } \\
\text { well number }\end{array}$ & Driller's description of materials & $\begin{array}{l}\text { Thickness } \\
\text { (feet) }\end{array}$ & $\begin{array}{l}\text { Depth of } \\
\text { bottom } \\
\text { (feet) }\end{array}$ & Driller's name & $\begin{array}{l}\text { Year } \\
\text { drilled }\end{array}$ \\
\hline $\begin{array}{l}\text { 19N/04E-03R01D2-- } \\
\text { continued }\end{array}$ & $\begin{array}{l}\text { Cemented sand and gravel } \\
\text { Sand and gravel, brown clay } \\
\text { Sand and gravel } \\
\text { Sand and gravel, gray clay } \\
\text { Gray silty sand, some gravel } \\
\text { Sand and clay } \\
\text { Dark gray silty sand } \\
\text { Sand and clay } \\
\text { Dark gray silty sand } \\
\text { Gray silty sand and clay } \\
\text { Sand, gravel and water } \\
\text { Gravel, sand and clay } \\
\text { Dirty sand and gravel, clay } \\
\text { Dirty sand and gravel } \\
\text { Dirty sand and gravel, clay }\end{array}$ & $\begin{array}{r}9 \\
4 \\
5 \\
1 \\
11 \\
18 \\
27 \\
20 \\
21 \\
1 \\
7 \\
12 \\
10 \\
12 \\
25\end{array}$ & $\begin{array}{l}636 \\
640 \\
645 \\
646 \\
657 \\
675 \\
702 \\
722 \\
743 \\
744 \\
751 \\
763 \\
773 \\
785 \\
810\end{array}$ & 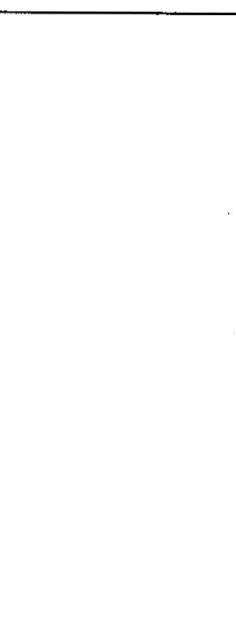 & 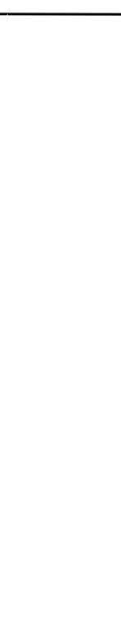 \\
\hline 19N/04E-05P02 & $\begin{array}{l}\text { Cemented gravel } \\
\text { Rocks and boulders } \\
\text { Cemented gravel } \\
\text { Sand layers and cemented gravel } \\
\text { Sand and gravel, water bearing }\end{array}$ & $\begin{array}{r}136 \\
26 \\
33 \\
10 \\
53\end{array}$ & $\begin{array}{l}136 \\
162 \\
195 \\
205 \\
258\end{array}$ & Gaudio & 1967 \\
\hline $19 \mathrm{~N} / 04 \mathrm{E}-08 \mathrm{~A} 01$ & $\begin{array}{l}\text { Gravel, sand and boulder } \\
\text { Yellow silt } \\
\text { Yellow silt, sand and gravel } \\
\text { Yellow silt } \\
\text { Silt, sand and gravel } \\
\text { Sand and gravel } \\
\text { Sand } \\
\text { Gravel } \\
\text { Gravel, up to 6" in diameter, coarse sand streaks of boulders } \\
\text { Sand }\end{array}$ & $\begin{array}{r}200 \\
5 \\
13 \\
6 \\
4 \\
10 \\
10 \\
11 \\
39 \\
6\end{array}$ & $\begin{array}{l}200 \\
205 \\
218 \\
224 \\
228 \\
238 \\
248 \\
259 \\
298 \\
304\end{array}$ & Gaudio & 1964 \\
\hline
\end{tabular}


Appendix 2.--Drillers' lithologic logs of wells used in construction of hydrogeologic sections, in the Tacoma-Puyallup area, Washington--Continued

\begin{tabular}{|c|c|c|c|c|c|}
\hline $\begin{array}{l}\text { Local } \\
\text { well number }\end{array}$ & Driller's description of materials & $\begin{array}{l}\text { Thickness } \\
\text { (feet) }\end{array}$ & $\begin{array}{l}\text { Depth of } \\
\text { bottom } \\
\text { (feet) }\end{array}$ & Driller's name & $\begin{array}{l}\text { Year } \\
\text { drilled }\end{array}$ \\
\hline \multirow[t]{33}{*}{ 19N/04E-08A06 } & Clay and boulders & 22 & 22 & Gaudio & 1965 \\
\hline & Gravel and boulders & 13 & 35 & & \\
\hline & Rock and gravel & 5 & 40 & & \\
\hline & Gravel and rock & 27 & 67 & & \\
\hline & Cemented gravel & 8 & 75 & & \\
\hline & Gravel and sand & 1 & 76 & & \\
\hline & Rocks, sand and gravel & 7 & 83 & & \\
\hline & Tight sand and gravel & 8 & 91 & & \\
\hline & Gravel and sand & 19 & 110 & & \\
\hline & $\begin{array}{l}\text { Tight sand and gravel } \\
\text { Gravel and sand }\end{array}$ & $\begin{array}{l}10 \\
10\end{array}$ & $\begin{array}{l}120 \\
130\end{array}$ & & \\
\hline & Tight gravel and sand & 18 & 148 & & \\
\hline & Sand and gravel (takes water) & 15 & 163 & & \\
\hline & Tight sand and gravel & 15 & 178 & & \\
\hline & Tight sand, gravel and rock & 6 & 184 & & \\
\hline & Streaks of sand and gravel & 16 & 200 & & \\
\hline & Rock and sand & 15 & 215 & & \\
\hline & Sand and gravel & 17 & 232 & & \\
\hline & Sand and gravel, some water & 8 & 240 & & \\
\hline & Blue silt & 15 & 255 & & \\
\hline & Silty sand & 4 & 259 & & \\
\hline & Sand, layer of clay & 13 & 272 & & \\
\hline & Tight yellow clay & 3 & 275 & & \\
\hline & Sand, layer of clay & 11 & 286 & & \\
\hline & Tight sand & 14 & 300 & & \\
\hline & Cemented gravel & 8 & 308 & & \\
\hline & Streaks & 6 & 314 & & \\
\hline & Fine sand, some gravel & 4 & 318 & & \\
\hline & Tight gravel and sand & 12 & 330 & & \\
\hline & Streaks of gravel and sand & 7 & 337 & & \\
\hline & Loose gravel & 4 & 341 & & \\
\hline & Tight gravel & 1 & 342 & & \\
\hline & Loose gravel & 9 & 351 & & \\
\hline & Hardpan & 2 & 353 & & \\
\hline
\end{tabular}


Appendix 2.--Drillers' lithologic logs of wells used in construction of hydrogeologic sections, in the Tacoma-Puyallup area, Washington--Continued

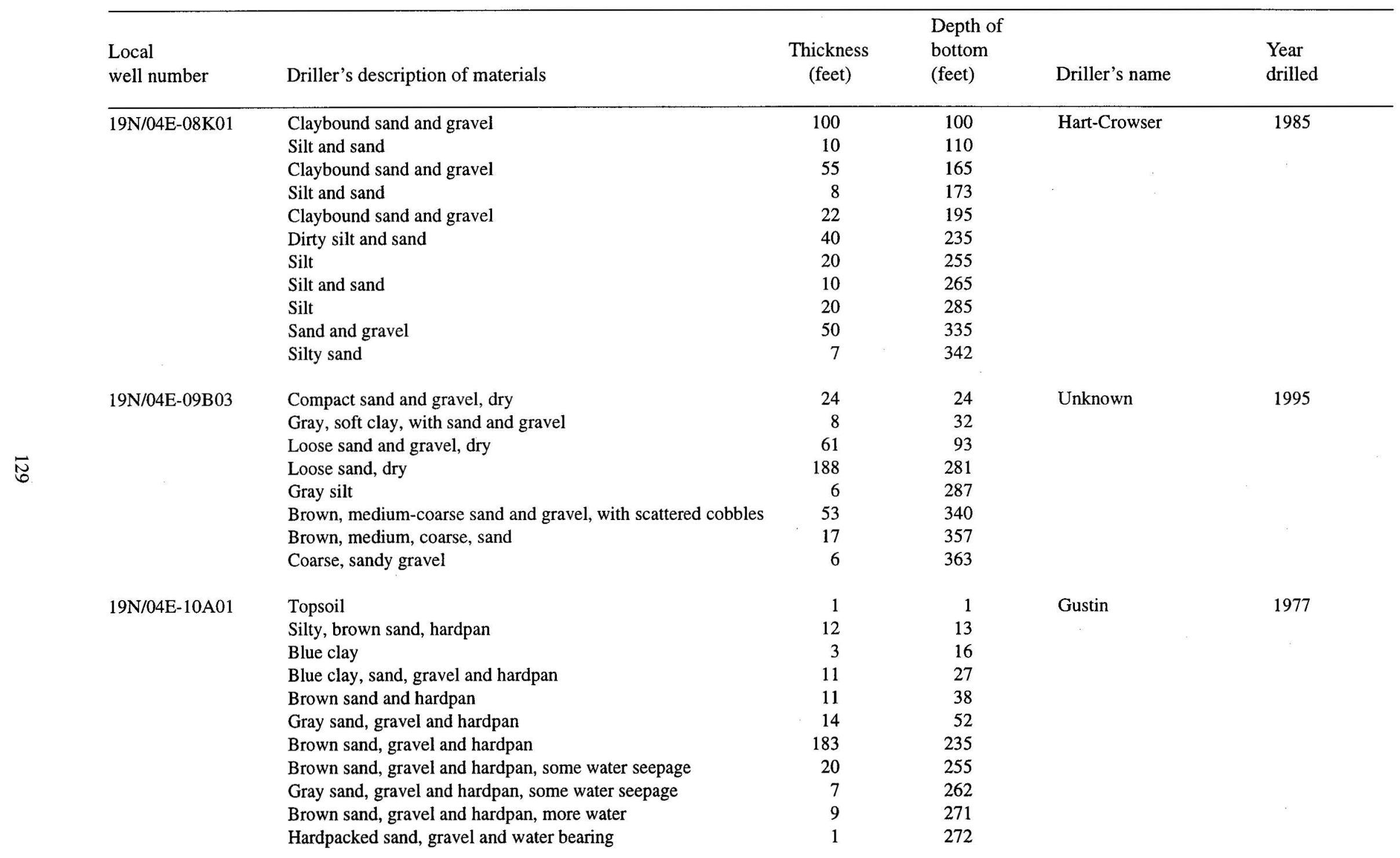


Appendix 2.--Drillers' lithologic logs of wells used in construction of hydrogeologic sections, in the Tacoma-Puyallup area, Washington--Continued

\begin{tabular}{|c|c|c|c|c|c|}
\hline $\begin{array}{l}\text { Local } \\
\text { well number }\end{array}$ & Driller's description of materials & $\begin{array}{l}\text { Thickness } \\
\text { (feet) }\end{array}$ & $\begin{array}{l}\text { Depth of } \\
\text { bottom } \\
\text { (feet) }\end{array}$ & Driller's name & $\begin{array}{l}\text { Year } \\
\text { drilled }\end{array}$ \\
\hline 19N/04E-11D01 & $\begin{array}{l}\text { Brown, silty, sandy gravel } \\
\text { Dark brown, silty gravel } \\
\text { Brown sand } \\
\text { Brown silty sandy gravel } \\
\text { Brown silty sandy gravel, wet } \\
\text { Clean gravel and water }\end{array}$ & $\begin{array}{r}29 \\
9 \\
14 \\
43 \\
14 \\
10\end{array}$ & $\begin{array}{r}29 \\
38 \\
52 \\
95 \\
109 \\
119\end{array}$ & Oelke & 1979 \\
\hline 19N/04E-11D02 & $\begin{array}{l}\text { Brown topsoil } \\
\text { Brown cemented sand and gravel } \\
\text { Blue glacial till } \\
\text { Brown cemented sand and gravel } \\
\text { Brown cemented sand and gravel } \\
\text { Coarse gravel with boulders } \\
\text { Brown glacial till } \\
\text { Brown cemented sand and gravel } \\
\text { Blue glacial till } \\
\text { Brown cemented sand and gravel, water bearing }\end{array}$ & $\begin{array}{r}2 \\
18 \\
15 \\
80 \\
35 \\
10 \\
65 \\
10 \\
23 \\
22\end{array}$ & $\begin{array}{r}2 \\
20 \\
35 \\
115 \\
150 \\
160 \\
225 \\
235 \\
258 \\
280\end{array}$ & Northwest Pump & 1991 \\
\hline 19N/04E-14P01 & $\begin{array}{l}\text { Topsoil } \\
\text { Sand } \\
\text { Gravel } \\
\text { Hardpan }\end{array}$ & $\begin{array}{r}2 \\
4 \\
14 \\
2\end{array}$ & $\begin{array}{r}2 \\
6 \\
20 \\
22\end{array}$ & Unknown & 1921 \\
\hline 19N/04E-16E01 & $\begin{array}{l}\text { Topsoil } \\
\text { Clay and gravel } \\
\text { Hardpan } \\
\text { Hardpan, seepage } \\
\text { Hardpan and boulders } \\
\text { Gravel, clay and boulders } \\
\text { Clay and gravel } \\
\text { Sand and clay } \\
\text { Gravel and clay } \\
\text { Hardpan } \\
\text { Gravel and clay }\end{array}$ & $\begin{array}{r}3 \\
7 \\
8 \\
1 \\
18 \\
80 \\
41 \\
5 \\
26 \\
47 \\
42\end{array}$ & $\begin{array}{r}3 \\
10 \\
18 \\
19 \\
37 \\
117 \\
158 \\
163 \\
189 \\
236 \\
278\end{array}$ & Richardson & 1975 \\
\hline
\end{tabular}


Appendix 2.--Drillers' lithologic logs of wells used in construction of hydrogeologic sections, in the Tacoma-Puyallup area, Washington--Continued

\begin{tabular}{|c|c|c|c|c|c|}
\hline $\begin{array}{l}\text { Local } \\
\text { well number }\end{array}$ & Driller's description of materials & $\begin{array}{l}\text { Thickness } \\
\text { (feet) }\end{array}$ & $\begin{array}{l}\text { Depth of } \\
\text { bottom } \\
\text { (feet) }\end{array}$ & Driller's name & $\begin{array}{l}\text { Year } \\
\text { drilled }\end{array}$ \\
\hline $\begin{array}{l}\text { 19N/04E-16E01-- } \\
\text { continued }\end{array}$ & $\begin{array}{l}\text { Clay and gravel } \\
\text { Clay and gravel, little water } \\
\text { Gravel and water }\end{array}$ & $\begin{array}{r}7 \\
12 \\
8\end{array}$ & $\begin{array}{l}285 \\
297 \\
305\end{array}$ & & \\
\hline 19N/04E-16E02D2 & $\begin{array}{l}\text { Topsoil } \\
\text { Blue clay } \\
\text { Sandy blue clay } \\
\text { Cemented gravel } \\
\text { Hardpan } \\
\text { Cemented gravel } \\
\text { Hardpan } \\
\text { Cemented gravel } \\
\text { Gravel, dry } \\
\text { Cemented gravel } \\
\text { Muddy sand, wet } \\
\text { Silt and sand, dry } \\
\text { Silt and sand, wet } \\
\text { Sand, little water } \\
\text { Cemented gravel } \\
\text { Hard-packed gravel and water } \\
\text { Gravel, some sand, water (good flow) } \\
\text { Gravel and water } \\
\text { Cemented gravel } \\
\text { Sand, gravel and brown clay } \\
\text { Brown silty sand and gravel, water } \\
\text { Brown clay sand and gravel } \\
\text { Brown silty sand and gravel, water } \\
\text { Brown clay sand and gravel } \\
\text { Red-brown silty sand and gravel, water } \\
\text { Loose sand and gravel, water } \\
\text { Gray sand and gravel, water } \\
\text { Gray clay sand and gravel } \\
\text { Gray silty sand and gravel, water } \\
\text { Gray medium sand, some gravel, heaves, water }\end{array}$ & $\begin{array}{r}1 \\
3 \\
12 \\
7 \\
6 \\
8 \\
42 \\
35 \\
23 \\
103 \\
4 \\
5 \\
23 \\
1 \\
8 \\
3 \\
12 \\
14 \\
1 \\
1 \\
19 \\
3 \\
1 \\
15 \\
9 \\
6 \\
8 \\
5 \\
7 \\
55\end{array}$ & $\begin{array}{r}1 \\
4 \\
16 \\
23 \\
29 \\
37 \\
79 \\
114 \\
137 \\
240 \\
244 \\
249 \\
272 \\
273 \\
281 \\
284 \\
296 \\
310 \\
311 \\
312 \\
331 \\
334 \\
335 \\
350 \\
359 \\
365 \\
373 \\
378 \\
385 \\
440\end{array}$ & Ramlo & 1986 \\
\hline
\end{tabular}


Appendix 2.--Drillers' lithologic logs of wells used in construction of hydrogeologic sections, in the Tacoma-Puyallup area, Washington--Continued

\begin{tabular}{|c|c|c|c|c|c|}
\hline $\begin{array}{l}\text { Local } \\
\text { well number }\end{array}$ & Driller's description of materials & $\begin{array}{l}\text { Thickness } \\
\text { (feet) }\end{array}$ & $\begin{array}{l}\text { Depth of } \\
\text { bottom } \\
\text { (feet) }\end{array}$ & Driller's name & $\begin{array}{l}\text { Year } \\
\text { drilled }\end{array}$ \\
\hline 19N/04E-17K01 & $\begin{array}{l}\text { Brown, silty topsoil } \\
\text { Gray sand, clay and gravel } \\
\text { Brown cemented gravel } \\
\text { Blue-gray till } \\
\text { Gray-brown cemented sand and gravel, large rocks } \\
\text { Brown clay and sand } \\
\text { Cemented gray sand and gravel } \\
\text { Brown sandy clay, some gravel } \\
\text { Light, fine medium sand with clay binder } \\
\text { Gray-brown sand and water } \\
\text { Gravel and water } \\
\text { Gray clay }\end{array}$ & $\begin{array}{r}3 \\
8 \\
8 \\
63 \\
159 \\
27 \\
15 \\
19 \\
43 \\
15 \\
13 \\
1\end{array}$ & $\begin{array}{r}3 \\
11 \\
19 \\
82 \\
241 \\
268 \\
283 \\
302 \\
345 \\
360 \\
373 \\
374\end{array}$ & Stoican & 1984 \\
\hline $19 \mathrm{~N} / 04 \mathrm{E}-20 \mathrm{~F} 02$ & $\begin{array}{l}\text { Brown silty sand and gravel } \\
\text { Medium, coarse, clean sand } \\
\text { Brown sand and gravel } \\
\text { Gray till } \\
\text { Brown silty sand and gravel } \\
\text { Clean, broken gravel and sand } \\
\text { Medium gravel and sand }\end{array}$ & $\begin{array}{r}6 \\
3 \\
70 \\
26 \\
14 \\
15 \\
6\end{array}$ & $\begin{array}{r}6 \\
9 \\
79 \\
105 \\
119 \\
134 \\
140\end{array}$ & Oelke & 1978 \\
\hline 19N/04E-20K03 & $\begin{array}{l}\text { Till } \\
\text { Cemented gravel } \\
\text { Gravel and sand }\end{array}$ & $\begin{array}{r}85 \\
105 \\
5\end{array}$ & $\begin{array}{r}85 \\
190 \\
195\end{array}$ & Denny & 1940 \\
\hline 19N/04E-20Q01D1 & $\begin{array}{l}\text { Hardpan and boulders } \\
\text { Hardpan } \\
\text { Gravel, water bearing } \\
\text { Sand, gravel, water bearing } \\
\text { Brown sandy clay } \\
\text { Brown fine sand, water bearing } \\
\text { Brown medium sand, water bearing } \\
\text { Gray-blue clay with gravel } \\
\text { Cemented gravel, water bearing }\end{array}$ & $\begin{array}{r}30 \\
70 \\
13 \\
7 \\
5 \\
12 \\
10 \\
11 \\
84\end{array}$ & $\begin{array}{r}30 \\
100 \\
113 \\
120 \\
125 \\
137 \\
147 \\
158 \\
242\end{array}$ & Ramlo & 1986 \\
\hline
\end{tabular}


Appendix 2.--Drillers' lithologic logs of wells used in construction of hydrogeologic sections, in the Tacoma-Puyallup area, Washington--Continued

\begin{tabular}{|c|c|c|c|c|c|}
\hline $\begin{array}{l}\text { Local } \\
\text { well number }\end{array}$ & Driller's description of materials & $\begin{array}{l}\text { Thickness } \\
\text { (feet) }\end{array}$ & $\begin{array}{l}\text { Depth of } \\
\text { bottom } \\
\text { (feet) }\end{array}$ & Driller's name & $\begin{array}{l}\text { Year } \\
\text { drilled }\end{array}$ \\
\hline \multirow{4}{*}{$\begin{array}{l}\text { 19N/04E-20Q01D1-- } \\
\text { continued }\end{array}$} & Silty loose sand and gravel, water bearing & 5 & 247 & & \\
\hline & Cemented gravel, water bearing & 68 & 315 & & \\
\hline & Sand and gravel, water bearing & 5 & 320 & & \\
\hline & Cemented gravel, water bearing & 5 & 325 & & \\
\hline \multirow[t]{18}{*}{ 19N/04E-20R04 } & Bankrun & 5 & 5 & Richardson & 1969 \\
\hline & Hardpan & 45 & 50 & & \\
\hline & Gravel and clay & 8 & 58 & & \\
\hline & Hardpan & 90 & 148 & & \\
\hline & Coarse sand and gravel, some water & 11 & 159 & & \\
\hline & Coarse sand and clay & 1 & 160 & & \\
\hline & Coarse sand and gravel, some water & 4 & 164 & & \\
\hline & Gray-blue clay & 10 & 174 & & \\
\hline & Sandy clay & 2 & 176 & & \\
\hline & Hardpan & 4 & 180 & & \\
\hline & Coarse sand and gravel, water & 6 & 186 & & \\
\hline & Gray-blue clay and gravel & 7 & 193 & & \\
\hline & Gray sandy clay & 10 & 203 & & \\
\hline & Blue clay & 1 & 204 & & \\
\hline & Blue-gray clay and gravel & 18 & 222 & & \\
\hline & Light brown sandy clay and gravel & 16 & 238 & & \\
\hline & Clay coated gravel & 7 & 245 & & \\
\hline & Coarse gravel & 1 & 246 & & \\
\hline \multirow[t]{8}{*}{ 19N/04E-20R05 } & Hardpan & 69 & 69 & Holt & 1989 \\
\hline & Sand and gravel, silt binder & 87 & 156 & & \\
\hline & Sand and gravel, water & 11 & 167 & & \\
\hline & Green-gray silt & 8 & 175 & & \\
\hline & Silty sand and gravel & 16 & 191 & & \\
\hline & Tight silty sand & 14 & 205 & & \\
\hline & Loose sand and gravel, some water & 15 & 220 & & \\
\hline & Tight sand and gravel, water & 41 & 261 & & \\
\hline
\end{tabular}


Appendix 2.--Drillers' lithologic logs of wells used in construction of hydrogeologic sections, in the Tacoma-Puyallup area, Washington--Continued

\begin{tabular}{|c|c|c|c|c|c|}
\hline $\begin{array}{l}\text { Local } \\
\text { well number }\end{array}$ & Driller's description of materials & $\begin{array}{c}\text { Thickness } \\
\text { (feet) }\end{array}$ & $\begin{array}{l}\text { Depth of } \\
\text { bottom } \\
\text { (feet) }\end{array}$ & Driller's name & $\begin{array}{l}\text { Year } \\
\text { drilled }\end{array}$ \\
\hline \multirow[t]{4}{*}{ 19N/04E-25K02 } & Brown silty sand and gravel & 8 & 8 & Oelke & 1993 \\
\hline & Brown-gray silty sand with clay & 14 & 22 & & \\
\hline & Gray silty sand with clay, some gravel & 52 & 74 & & \\
\hline & Coarse to medium sand, gravel, water bearing & 23 & 97 & & \\
\hline \multirow[t]{22}{*}{ 19N/04E-26C01 } & Topsoil & 3 & 3 & Indrebo & 1977 \\
\hline & Brown sand, clay and some rock & 21 & 24 & & \\
\hline & Cemented gravel and boulders & 4 & 28 & & \\
\hline & Blue hard clay and gravel & 4 & 32 & & \\
\hline & Brown clay and gravel, some water & 2 & 34 & & \\
\hline & Cemented gravel & 131 & 165 & & \\
\hline & Yellow-brown hard clay and gravel & 29 & 194 & & \\
\hline & Brown sandy clay, some gravel & 5 & 199 & & \\
\hline & Cemented gravel & 11 & 210 & & \\
\hline & Cemented gravel and water & 4 & 214 & & \\
\hline & Clay and gravel, some boulders, water shutoff & 16 & 230 & & \\
\hline & Blue hardpan & 10 & 240 & & \\
\hline & Brown clay and gravel, trace water & 10 & 250 & & \\
\hline & Blue hardpan & 3 & 253 & & \\
\hline & Brown clay and gravel, some water & 9 & 262 & & \\
\hline & Brown clay and gravel, water shutoff & 10 & 272 & & \\
\hline & Brown clay and gravel, water $2 \mathrm{gpm}$ & 3 & 275 & & \\
\hline & Brown clay and gravel, water shutoff & 25 & 300 & & \\
\hline & Brown clay and gravel, water & 7 & 307 & & \\
\hline & Brown silty clay & 2 & 309 & & \\
\hline & Brown silty clay, fine sand and gravel, some water & 7 & 316 & & \\
\hline & Brown clay and gravel & 34 & 350 & & \\
\hline \multirow[t]{6}{*}{ 19N/04E-26G01 } & Topsoil & 5 & 5 & Story/Armstrong & 1978 \\
\hline & Large boulders & 3 & 8 & & \\
\hline & Gray cemented till & 7 & 15 & & \\
\hline & Hard cemented till & 6 & 21 & & \\
\hline & Blue hard cemented till & 21 & 42 & & \\
\hline & Brown hard cemented till & 21 & 63 & & \\
\hline
\end{tabular}


Appendix 2.--Drillers' lithologic logs of wells used in construction of hydrogeologic sections, in the Tacoma-Puyallup area, Washington--Continued

\begin{tabular}{|c|c|c|c|c|c|}
\hline $\begin{array}{l}\text { Local } \\
\text { well number }\end{array}$ & Driller's description of materials & $\begin{array}{l}\text { Thickness } \\
\text { (feet) }\end{array}$ & $\begin{array}{l}\text { Depth of } \\
\text { bottom } \\
\text { (feet) }\end{array}$ & Driller's name & $\begin{array}{l}\text { Year } \\
\text { drilled }\end{array}$ \\
\hline $\begin{array}{l}\text { 19N/04E-26G01-- } \\
\text { continued }\end{array}$ & $\begin{array}{l}\text { Compact sand, with gravel } \\
\text { Dirty compact sand with gravel, no water } \\
\text { Brown sand } \\
\text { Gray cemented sand and gravel } \\
\text { Brown cemented sand and gravel } \\
\text { Gray, very tight cemented sand and gravel } \\
\text { Looser cemented sand and gravel } \\
\text { Brown sand, trace water } \\
\text { Light brown silty material, with gravel } \\
\text { Gray cemented sandy till } \\
\text { Blue cemented till } \\
\text { Blue cemented till, sand and gravel, trace water } \\
\text { Blue-green very tight till } \\
\text { Blue cemented sand and gravel } \\
\text { Gray cemented sand and gravel } \\
\text { Gray-brown cemented sandy till } \\
\text { Sand, trace of gravel } \\
\text { Brown-gray silty sand, trace water } \\
\text { Brown silty sand, with gravel } \\
\text { Hard cemented till, with large rocks } \\
\text { Fine sand, slight trace of water } \\
\text { Brown sand, with gravel, water bearing, getting coarser, } \\
\text { very fine gravel with sand } \\
\text { Sticky clay }\end{array}$ & $\begin{array}{r}11 \\
11 \\
3 \\
77 \\
15 \\
4 \\
6 \\
3 \\
7 \\
17 \\
35 \\
2 \\
1 \\
8 \\
5 \\
9 \\
3 \\
40 \\
26 \\
2 \\
10 \\
\\
11 \\
2\end{array}$ & $\begin{array}{r}74 \\
85 \\
88 \\
165 \\
180 \\
184 \\
190 \\
193 \\
200 \\
217 \\
252 \\
254 \\
255 \\
263 \\
268 \\
277 \\
280 \\
320 \\
346 \\
348 \\
358 \\
369 \\
371\end{array}$ & & \\
\hline 19N/04E-27A01 & $\begin{array}{l}\text { Blue silty claybound sand and gravel } \\
\text { Sand and gravel } \\
\text { Tight silty sand and gravel } \\
\text { Sand and gravel, water bearing } \\
\text { Silty claybound sand and gravel }\end{array}$ & $\begin{array}{r}198 \\
6 \\
1 \\
17 \\
3\end{array}$ & $\begin{array}{l}198 \\
204 \\
205 \\
222 \\
225\end{array}$ & Story/Armstrong & 1975 \\
\hline 19N/04E-27B01 & $\begin{array}{l}\text { Sand } \\
\text { Hardpan }\end{array}$ & $\begin{array}{l}8.5 \\
0.5\end{array}$ & $\begin{array}{l}8.5 \\
9\end{array}$ & Unknown & Unk \\
\hline
\end{tabular}


Appendix 2.--Drillers' lithologic logs of wells used in construction of hydrogeologic sections, in the Tacoma-Puyallup area, Washington--Continued

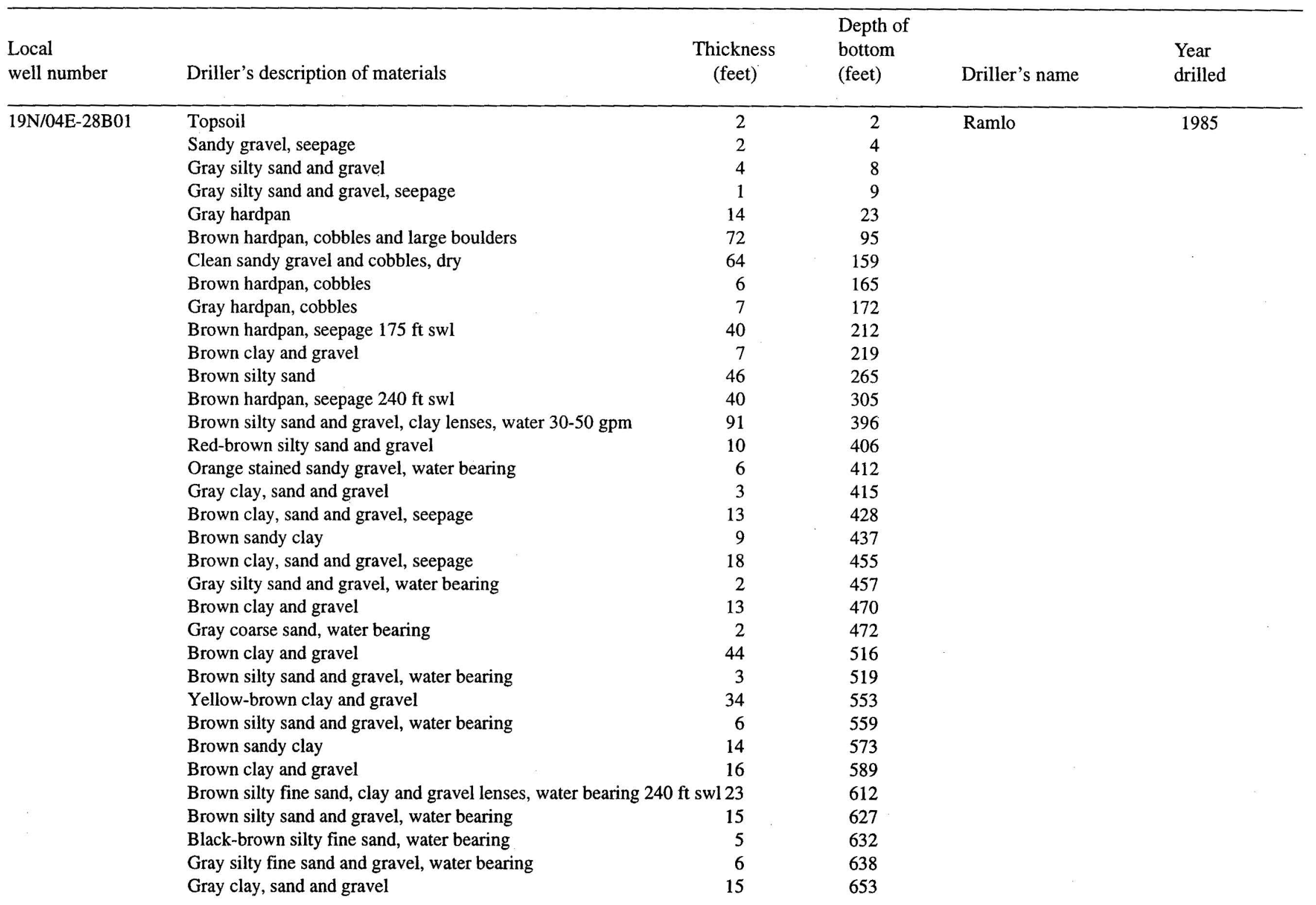


Appendix 2.--Drillers' lithologic logs of wells used in construction of hydrogeologic sections, in the Tacoma-Puyallup area, Washington--Continued

\begin{tabular}{|c|c|c|c|c|c|}
\hline $\begin{array}{l}\text { Local } \\
\text { well number }\end{array}$ & Driller's description of materials & $\begin{array}{l}\text { Thickness } \\
\text { (feet) }\end{array}$ & $\begin{array}{l}\text { Depth of } \\
\text { bottom } \\
\text { (feet) }\end{array}$ & Driller's name & $\begin{array}{l}\text { Year } \\
\text { drilled }\end{array}$ \\
\hline $\begin{array}{l}\text { 19N/04E-28B01-- } \\
\text { continued }\end{array}$ & $\begin{array}{l}\text { Gray loose sandy gravel, water bearing, } 230 \mathrm{ft} \mathrm{swl} \\
\text { Gray clay sand and gravel } \\
\text { Gray silty sand and gravel, water bearing } \\
\text { Gray clay sand and gravel } \\
\text { Gray sandy loose gravel, water bearing, } 230 \mathrm{ft} \mathrm{swl} \\
\text { Gray clay }\end{array}$ & $\begin{array}{r}5 \\
6 \\
2 \\
4 \\
11 \\
16\end{array}$ & $\begin{array}{l}658 \\
664 \\
666 \\
670 \\
681 \\
697\end{array}$ & & \\
\hline 19N/04E-29J01 & $\begin{array}{l}\text { Brown soil } \\
\text { Sand and gravel, little clay, water } 5 \mathrm{gpm} \\
\text { Hardpan and boulders } \\
\text { Sand, gravel and brown clay, water } 1.5 \mathrm{gpm} \\
\text { Sand, gravel and brown clay, wet } \\
\text { Sand and gravel, water } 25 \mathrm{gpm}\end{array}$ & $\begin{array}{r}2 \\
16 \\
112 \\
12 \\
28 \\
29\end{array}$ & $\begin{array}{r}2 \\
18 \\
130 \\
142 \\
170 \\
199\end{array}$ & Richardson & 1977 \\
\hline $19 \mathrm{~N} / 04 \mathrm{E}-29 \mathrm{~K} 02$ & $\begin{array}{l}\text { Brown silty sand and gravel } \\
\text { Gray hard till, damp } \\
\text { Brown silty sand and gravel, damp } \\
\text { Gray silty sand and gravel, damp } \\
\text { Brown silty sand and gravel, damp } \\
\text { Till } \\
\text { Brown silty sand and gravel, damp } \\
\text { Brown hard silty sand and gravel, wet }\end{array}$ & $\begin{array}{r}3 \\
35 \\
2 \\
13 \\
82 \\
2 \\
6 \\
37\end{array}$ & $\begin{array}{r}3 \\
38 \\
40 \\
53 \\
135 \\
137 \\
143 \\
180\end{array}$ & Oelke & 1982 \\
\hline 19N/04E-29L03 & $\begin{array}{l}\text { Sandy topsoil } \\
\text { Sand, clay and gravel } \\
\text { Gravel, clay and boulders } \\
\text { Gray hardpan } \\
\text { Yellow hardpan } \\
\text { Large boulder } \\
\text { Brownish hardpan } \\
\text { Yellow hardpan } \\
\text { Sand and gravel, trace water } \\
\text { Brown gravel and clay } \\
\text { Gravel and sand, water } \\
\text { Gravel and clay, water }\end{array}$ & $\begin{array}{r}2 \\
7 \\
13 \\
16 \\
29 \\
2 \\
2 \\
46 \\
43 \\
7 \\
26 \\
7 \\
7 \\
4\end{array}$ & $\begin{array}{r}2 \\
9 \\
22 \\
38 \\
67 \\
69 \\
115 \\
158 \\
165 \\
191 \\
198 \\
202\end{array}$ & Richardson & 1990 \\
\hline
\end{tabular}


Appendix 2.--Drillers' lithologic logs of wells used in construction of hydrogeologic sections, in the Tacoma-Puyallup area, Washington--Continued

\begin{tabular}{|c|c|c|c|c|c|}
\hline $\begin{array}{l}\text { Local } \\
\text { well number }\end{array}$ & Driller's description of materials & $\begin{array}{l}\text { Thickness } \\
\text { (feet) }\end{array}$ & $\begin{array}{l}\text { Depth of } \\
\text { bottom } \\
\text { (feet) }\end{array}$ & Driller's name & $\begin{array}{l}\text { Year } \\
\text { drilled }\end{array}$ \\
\hline 19N/04E-29M02 & $\begin{array}{l}\text { Sandy clay } \\
\text { Unconsolidated sand, gravel, and clay } \\
\text { Sandy clay } \\
\text { Consolidated sand, gravel, and clay } \\
\text { Gravel, some sand } \\
\text { Gravel and water }\end{array}$ & $\begin{array}{r}3 \\
11 \\
2 \\
19 \\
100 \\
25\end{array}$ & $\begin{array}{r}3 \\
14 \\
16 \\
35 \\
135 \\
160\end{array}$ & Kring & 1989 \\
\hline 19N/04E-29R03 & $\begin{array}{l}\text { Topsoil and gravel } \\
\text { Hardpan } \\
\text { Sand and gravel, water } \\
\text { Loose gravel, water }\end{array}$ & $\begin{array}{r}6 \\
134 \\
8 \\
1\end{array}$ & $\begin{array}{r}6 \\
140 \\
148 \\
149\end{array}$ & Tacoma Pump & 1975 \\
\hline 19N/04E-30Q03 & $\begin{array}{l}\text { Topsoil } \\
\text { Brown glacial till } \\
\text { Blue glacial till } \\
\text { Brown cemented sand and gravel } \\
\text { Sand and gravel, water bearing } \\
\text { Brown silty sand } \\
\text { Brown cemented sand and gravel } \\
\text { Sand and gravel, water bearing }\end{array}$ & $\begin{array}{r}3 \\
8 \\
19 \\
88 \\
5 \\
19 \\
11 \\
7\end{array}$ & $\begin{array}{r}3 \\
11 \\
30 \\
118 \\
123 \\
142 \\
153 \\
160\end{array}$ & Northwest Pump & 1989 \\
\hline $19 \mathrm{~N} / 04 \mathrm{E}-31 \mathrm{C} 03$ & $\begin{array}{l}\text { Brown clay, cobbles, and gravel } \\
\text { Brown clay, gravel, mild sand } \\
\text { Brown clay, sand, and gravel } \\
\text { Brown clay, sand, and gravel, mild } \\
\text { Brown clay and gravel } \\
\text { Gravel, sand and water } \\
\text { Clay, sand mild gravel }\end{array}$ & $\begin{array}{r}7 \\
105 \\
15 \\
8 \\
2 \\
3 \\
1\end{array}$ & $\begin{array}{r}7 \\
112 \\
127 \\
135 \\
137 \\
140 \\
141\end{array}$ & Northern Pump & 1986 \\
\hline $19 \mathrm{~N} / 05 \mathrm{E}-06 \mathrm{~N} 02$ & $\begin{array}{l}\text { Brown topsoil } \\
\text { Gray silty sand, damp } \\
\text { Gray silty sand, water bearing } \\
\text { Gray silty sand and gravel, water bearing } \\
\text { Coarse gravel and sand, water bearing }\end{array}$ & $\begin{array}{r}8 \\
27 \\
21 \\
28 \\
16\end{array}$ & $\begin{array}{r}8 \\
35 \\
56 \\
84 \\
100\end{array}$ & Oelke & 1994 \\
\hline
\end{tabular}


Appendix 2.--Drillers' lithologic logs of wells used in construction of hydrogeologic sections, in the Tacoma-Puyallup area, Washington--Continued

\begin{tabular}{|c|c|c|c|c|c|}
\hline $\begin{array}{l}\text { Local } \\
\text { well number }\end{array}$ & Driller's description of materials & $\begin{array}{l}\text { Thickness } \\
\text { (feet) }\end{array}$ & $\begin{array}{l}\text { Depth of } \\
\text { bottom } \\
\text { (feet) }\end{array}$ & Driller's name & $\begin{array}{l}\text { Year } \\
\text { drilled }\end{array}$ \\
\hline 19N/05E-30N01 & $\begin{array}{l}\text { Topsoil } \\
\text { Clay } \\
\text { Blue clay and sand, some water } \\
\text { Gray sand and clay } \\
\text { Hard sand and gravel, water bearing }\end{array}$ & $\begin{array}{r}2 \\
8 \\
12 \\
60 \\
11\end{array}$ & $\begin{array}{r}2 \\
10 \\
22 \\
82 \\
93\end{array}$ & Jas. L. Bell & 1957 \\
\hline 19N/05E-30P01 & $\begin{array}{l}\text { Topsoil } \\
\text { Gravel } \\
\text { Sand } \\
\text { Sand and gravel, water bearing }\end{array}$ & $\begin{array}{r}2 \\
18 \\
35 \\
23\end{array}$ & $\begin{array}{r}2 \\
20 \\
55 \\
78\end{array}$ & Shartion & 1952 \\
\hline 20N/03E-30R01 & $\begin{array}{l}\text { Cobbles and concrete } \\
\text { Silty sand } \\
\text { Gravel } \\
\text { Till and sand }\end{array}$ & $\begin{array}{r}3 \\
14 \\
3 \\
10\end{array}$ & $\begin{array}{r}3 \\
17 \\
20 \\
30\end{array}$ & Burns & 1993 \\
\hline 20N/03E-32D01 & $\begin{array}{l}\text { Gravel } \\
\text { Till }\end{array}$ & $\begin{array}{r}13 \\
3\end{array}$ & $\begin{array}{l}13 \\
16\end{array}$ & Unknown & 1932 \\
\hline 20N/03E-34L01 & $\begin{array}{l}\text { Soil } \\
\text { Cemented gravel } \\
\text { Blue hardpan } \\
\text { Cemented gravel } \\
\text { Sand and gravel, dry } \\
\text { Cemented gravel } \\
\text { Dirty sand and gravel, some water } \\
\text { Cemented gravel } \\
\text { Sand and small gravel, water } \\
\text { Gravel and water } \\
\text { Cemented gravel } \\
\text { Big gravel and water } \\
\text { Cemented gravel }\end{array}$ & $\begin{array}{r}4 \\
31 \\
40 \\
65 \\
20 \\
24 \\
7 \\
4 \\
4 \\
3 \\
1 \\
9 \\
2\end{array}$ & $\begin{array}{r}4 \\
35 \\
75 \\
140 \\
160 \\
184 \\
191 \\
195 \\
199 \\
202 \\
203 \\
212 \\
214\end{array}$ & Sylte & 1951 \\
\hline
\end{tabular}


Appendix 2.--Drillers' lithologic logs of wells used in construction of hydrogeologic sections, in the Tacoma-Puyallup area, Washington--Continued

\begin{tabular}{|c|c|c|c|c|c|}
\hline $\begin{array}{l}\text { Local } \\
\text { well number }\end{array}$ & Driller's description of materials & $\begin{array}{l}\text { Thickness } \\
\text { (feet) }\end{array}$ & $\begin{array}{l}\text { Depth of } \\
\text { bottom } \\
\text { (feet) }\end{array}$ & Driller's name & $\begin{array}{l}\text { Year } \\
\text { drilled }\end{array}$ \\
\hline $\begin{array}{l}\text { 20N/03E-34L01-- } \\
\text { continued }\end{array}$ & $\begin{array}{l}\text { Sand and gravel, water } \\
\text { Dirty sand, wet } \\
\text { Cemented gravel } \\
\text { Hardpan } \\
\text { Cemented gravel } \\
\text { Fine sand, wet } \\
\text { Hardpan } \\
\text { Dirty sand and gravel, wet } \\
\text { Silt, dry } \\
\text { Quick sand } \\
\text { Heavy sand } \\
\text { Sand and gravel, water } \\
\text { Hardpan } \\
\text { Sand and gravel } \\
\text { Hardpan } \\
\text { Silt and gravel, dry } \\
\text { Hardpan } \\
\text { Sand and blue clay } \\
\text { Hardpan } \\
\text { Green clay } \\
\text { Brown hardpan }\end{array}$ & $\begin{array}{r}2 \\
7 \\
7 \\
8 \\
29 \\
2 \\
51 \\
10 \\
24 \\
30 \\
10 \\
2 \\
33 \\
1 \\
20 \\
4 \\
5 \\
11 \\
11 \\
4 \\
20\end{array}$ & $\begin{array}{l}216 \\
223 \\
230 \\
238 \\
267 \\
269 \\
320 \\
330 \\
354 \\
384 \\
394 \\
396 \\
429 \\
430 \\
450 \\
454 \\
459 \\
470 \\
481 \\
485 \\
505\end{array}$ & & \\
\hline 20N/03E-34L02 & $\begin{array}{l}\text { Yellow clay and gravel } \\
\text { Blue clay, sand and gravel hard streaks } \\
\text { Hardpan } \\
\text { Cemented sand and gravel } \\
\text { Hardpan, some water } \\
\text { Cemented sand and gravel, water } \\
\text { Fine and coarse sand and gravel, with yellow clay } \\
\text { Cemented sand and gravel } \\
\text { Fine sand, yellow clay and gravel } \\
\text { Cemented sand and gravel } \\
\text { Fine and coarse sand, yellow clay and gravel } \\
\text { Cemented sand and gravel, } 12 \mathrm{ft} \text { water }\end{array}$ & $\begin{array}{r}16 \\
26 \\
23 \\
23 \\
22 \\
38 \\
12 \\
11 \\
4 \\
2 \\
7 \\
4\end{array}$ & $\begin{array}{r}16 \\
42 \\
65 \\
88 \\
110 \\
148 \\
160 \\
171 \\
175 \\
177 \\
184 \\
188\end{array}$ & Richardson & 1966 \\
\hline
\end{tabular}


Appendix 2.--Drillers' lithologic logs of wells used in construction of hydrogeologic sections, in the Tacoma-Puyallup area, Washington--Continued

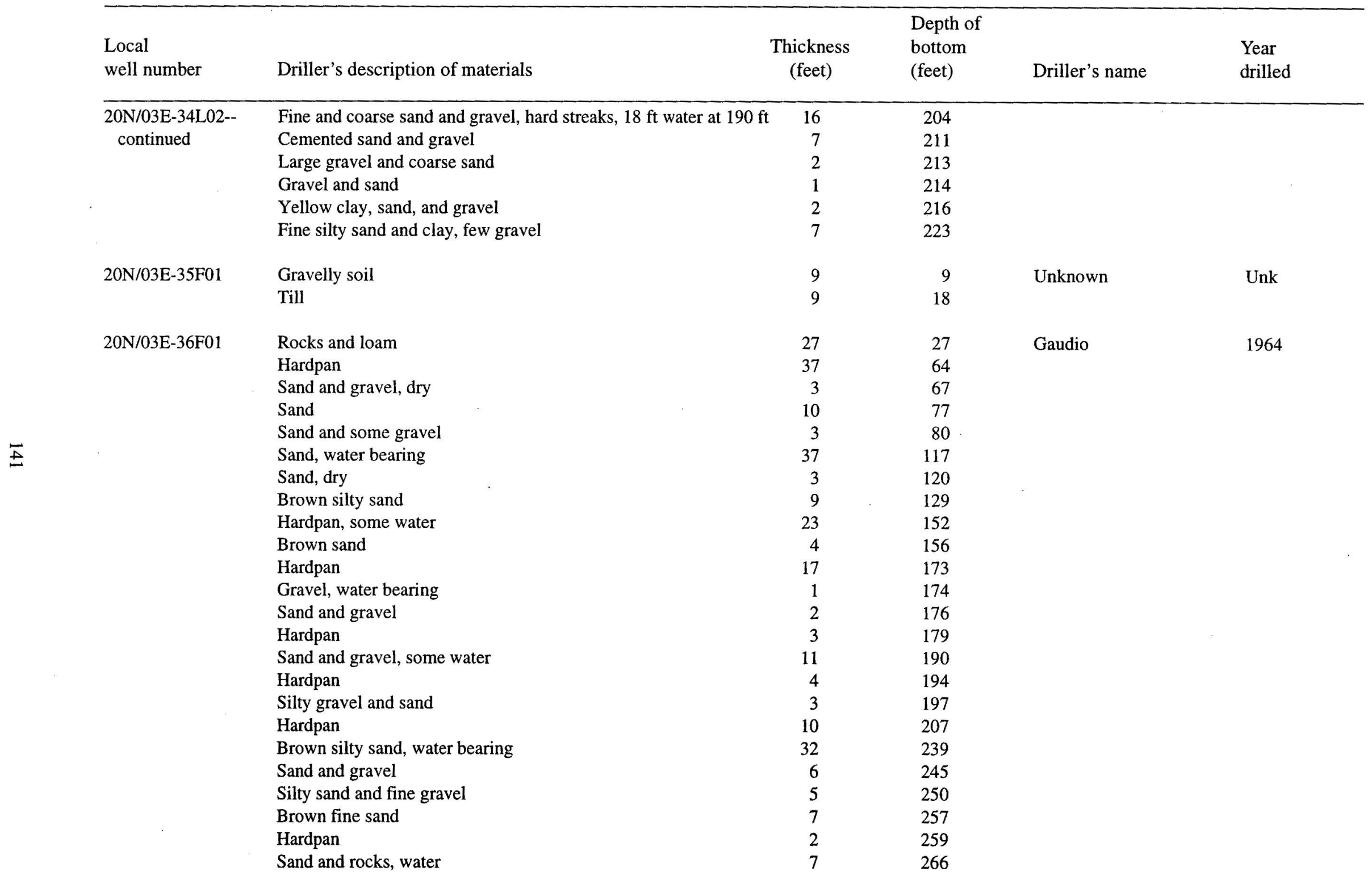


Appendix 2.--Drillers' lithologic logs of wells used in construction of hydrogeologic sections, in the Tacoma-Puyallup area, Washington--Continued

\begin{tabular}{|c|c|c|c|c|c|}
\hline $\begin{array}{l}\text { Local } \\
\text { well number }\end{array}$ & Driller's description of materials & $\begin{array}{l}\text { Thickness } \\
\text { (feet) }\end{array}$ & $\begin{array}{l}\text { Depth of } \\
\text { bottom } \\
\text { (feet) }\end{array}$ & Driller's name & $\begin{array}{l}\text { Year } \\
\text { drilled }\end{array}$ \\
\hline $\begin{array}{l}\text { 20N/03E-36F01-- } \\
\text { continued }\end{array}$ & $\begin{array}{l}\text { Hardpan } \\
\text { Sand, dry } \\
\text { Hardpan } \\
\text { Sand, streak of water } \\
\text { Hardpan } \\
\text { Sand, gravel and clay, water } \\
\text { Hardpan and boulders } \\
\text { Sand and gravel } \\
\text { Gravel, sand, cobbles, clay matrix } \\
\text { Unknown }\end{array}$ & $\begin{array}{r}15 \\
1 \\
9 \\
1 \\
5 \\
5 \\
6 \\
9 \\
50 \\
5\end{array}$ & $\begin{array}{l}281 \\
282 \\
291 \\
292 \\
297 \\
302 \\
308 \\
317 \\
367 \\
372\end{array}$ & & \\
\hline 20N/04E-20E04 & $\begin{array}{l}\text { Topsoil } \\
\text { Dark brown sand } \\
\text { Gray sandy clay } \\
\text { Gray sand } \\
\text { Sand and gravel, gray water }\end{array}$ & $\begin{array}{r}2 \\
23 \\
13 \\
14 \\
4\end{array}$ & $\begin{array}{r}2 \\
25 \\
38 \\
52 \\
56\end{array}$ & Johnson & 1983 \\
\hline 20N/04E-20E06 & $\begin{array}{l}\text { Topsoil } \\
\text { Brown silt } \\
\text { Gray silt } \\
\text { Gray coarse sand, small and medium gravel, damp } \\
\text { Brown silt } \\
\text { Gray silty clay, seashells and wood chips } \\
\text { Gray medium sand } \\
\text { Gray fine silt and sand }\end{array}$ & $\begin{array}{r}2 \\
7 \\
51 \\
14 \\
2 \\
2 \\
19 \\
20 \\
6\end{array}$ & $\begin{array}{r}2 \\
9 \\
60 \\
74 \\
76 \\
95 \\
115 \\
121\end{array}$ & Oelke & 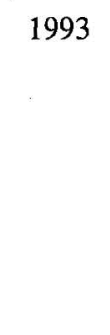 \\
\hline 20N/04E-20N05 & $\begin{array}{l}\text { Sand and clay, wet } \\
\text { Sand, clay, and wood, some water } \\
\text { Sandy clay, some water } \\
\text { Heaving sand } \\
\text { Sand, blue clay, and seashells } \\
\text { Compact sand and clay } \\
\text { Coarse sand, water } \\
\text { Sand and clay } \\
\text { Gray clay }\end{array}$ & $\begin{array}{r}60 \\
5 \\
15 \\
47 \\
8 \\
43 \\
6 \\
6 \\
3\end{array}$ & $\begin{array}{r}60 \\
65 \\
80 \\
127 \\
135 \\
178 \\
184 \\
190 \\
193\end{array}$ & Tacoma Pump & 1984 \\
\hline
\end{tabular}


Appendix 2.--Drillers' lithologic logs of wells used in construction of hydrogeologic sections, in the Tacoma-Puyallup area, Washington--Continued

\begin{tabular}{|c|c|c|c|c|c|}
\hline $\begin{array}{l}\text { Local } \\
\text { well number }\end{array}$ & Driller's description of materials & $\begin{array}{l}\text { Thickness } \\
\text { (feet) }\end{array}$ & $\begin{array}{l}\text { Depth of } \\
\text { bottom } \\
\text { (feet) }\end{array}$ & Driller's name & $\begin{array}{l}\text { Year } \\
\text { drilled }\end{array}$ \\
\hline $20 \mathrm{~N} / 04 \mathrm{E}-25 \mathrm{~N} 01$ & $\begin{array}{l}\text { Sand and clay } \\
\text { Gravel }\end{array}$ & $\begin{array}{l}80 \\
33\end{array}$ & $\begin{array}{r}80 \\
113\end{array}$ & Charlton & 1952 \\
\hline 20N/04E-25P01 & $\begin{array}{l}\text { Topsoil } \\
\text { Logs } \\
\text { Sandy clay } \\
\text { Sand, gravel, and water } \\
\text { Clay } \\
\text { Clay, sand, and gravel } \\
\text { Coarse sand }\end{array}$ & $\begin{array}{r}5 \\
4 \\
11 \\
30 \\
25 \\
15 \\
2\end{array}$ & $\begin{array}{r}5 \\
9 \\
20 \\
50 \\
75 \\
90 \\
92\end{array}$ & Tacoma Pump & 1953 \\
\hline 20N/04E-25Q01 & $\begin{array}{l}\text { Sand and clay } \\
\text { Gravel }\end{array}$ & $\begin{array}{l}95 \\
10\end{array}$ & $\begin{array}{r}95 \\
105\end{array}$ & Charlton & 1952 \\
\hline 20N/04E-27H01 & $\begin{array}{l}\text { Topsoil } \\
\text { Brown sand } \\
\text { Gray sand and clay } \\
\text { Sand, gravel, and clay } \\
\text { Sand and gravel, seepage } \\
\text { Gray silty clay } \\
\text { Sand and gravel, water }\end{array}$ & $\begin{array}{r}1 \\
44 \\
100 \\
9 \\
5 \\
24 \\
7\end{array}$ & $\begin{array}{r}1 \\
45 \\
145 \\
154 \\
159 \\
183 \\
190\end{array}$ & Richardson & 1980 \\
\hline 20N/04E-27J01 & $\begin{array}{l}\text { Sand } \\
\text { Sandy clay } \\
\text { Soft sandy clay and rocks } \\
\text { Dark gray sand and gravel up to } 3 " \\
\text { Fine sand and clay } \\
\text { Sand, clay, and rocks } \\
\text { Sand and clay } \\
\text { Sand and gravel } \\
\text { Clay } \\
\text { Sand and clay }\end{array}$ & $\begin{array}{r}20 \\
20 \\
46 \\
6 \\
34 \\
4 \\
4 \\
20 \\
5 \\
30 \\
22\end{array}$ & $\begin{array}{r}20 \\
40 \\
86 \\
92 \\
126 \\
130 \\
150 \\
155 \\
185 \\
207\end{array}$ & Gaudio & 1953 \\
\hline
\end{tabular}


Appendix 2.--Drillers' lithologic logs of wells used in construction of hydrogeologic sections, in the Tacoma-Puyallup area, Washington--Continued

\begin{tabular}{|c|c|c|c|c|c|}
\hline $\begin{array}{l}\text { Local } \\
\text { well number }\end{array}$ & Driller's description of materials & $\begin{array}{l}\text { Thickness } \\
\text { (feet) }\end{array}$ & $\begin{array}{l}\text { Depth of } \\
\text { bottom } \\
\text { (feet) }\end{array}$ & Driller's name & $\begin{array}{l}\text { Year } \\
\text { drilled }\end{array}$ \\
\hline $\begin{array}{l}\text { 20N/04E-27J01-- } \\
\text { continued }\end{array}$ & $\begin{array}{l}\text { Dirty sand and gravel } \\
\text { Sand and gravel, finner toward } 221 \mathrm{ft} \\
\text { Clay } \\
\text { Sand and gravel }\end{array}$ & $\begin{array}{l}6 \\
8 \\
6 \\
6\end{array}$ & $\begin{array}{l}213 \\
221 \\
227 \\
233\end{array}$ & & \\
\hline 20N/04E-29D03 & $\begin{array}{l}\text { Topsoil } \\
\text { Sandy silt, some water } \\
\text { Silt } \\
\text { Gray sandy clay } \\
\text { Silt } \\
\text { Sandy clay } \\
\text { Clay } \\
\text { Fine sand and pea gravel, water flows }\end{array}$ & $\begin{array}{r}2 \\
202 \\
27 \\
33 \\
11 \\
11 \\
51 \\
25\end{array}$ & $\begin{array}{r}2 \\
204 \\
231 \\
264 \\
275 \\
286 \\
337 \\
362\end{array}$ & Valley Pump & 1967 \\
\hline 20N/04E-31F02 & $\begin{array}{l}\text { Clay, sand, gravel, and cobbles } \\
\text { Brown mild clay, sand, and gravel } \\
\text { Brown hard clay, sand, and gravel } \\
\text { Brown mild clay, sand, and gravel } \\
\text { Brown hard clay, sand, and gravel } \\
\text { Gravel and water } \\
\text { Clay, sand, and gravel }\end{array}$ & $\begin{array}{r}15 \\
18 \\
63 \\
58 \\
26 \\
10 \\
1\end{array}$ & $\begin{array}{r}15 \\
33 \\
96 \\
154 \\
180 \\
190 \\
191\end{array}$ & Northern Pump & 1987 \\
\hline 20N/04E-31H05 & $\begin{array}{l}\text { Topsoil } \\
\text { Sand with rocks } \\
\text { Gray sand and gravel, wet } \\
\text { Fine gravel } \\
\text { Sand, some gravel, wet and rusty } \\
\text { Gravel and sand, water } 5 \text { gpm and rusty } \\
\text { Sand } \\
\text { Gravel and sand, some red clay } \\
\text { Gravel, some sand, } 3 \text { gpm, pumped dry } \\
\text { Sand, wet and brown } \\
\text { Gravel, blue, green, brown, and black with some white and yellow }\end{array}$ & $\begin{array}{r}2 \\
18 \\
47 \\
4 \\
22 \\
4 \\
3 \\
40 \\
22 \\
15 \\
15\end{array}$ & $\begin{array}{r}2 \\
20 \\
67 \\
71 \\
93 \\
97 \\
100 \\
140 \\
162 \\
177 \\
192\end{array}$ & Richardson & 1978 \\
\hline
\end{tabular}


Appendix 2.--Drillers' lithologic logs of wells used in construction of hydrogeologic sections, in the Tacoma-Puyallup area, Washington--Continued

\begin{tabular}{|c|c|c|c|c|c|}
\hline $\begin{array}{l}\text { Local } \\
\text { well number }\end{array}$ & Driller's description of materials & $\begin{array}{l}\text { Thickness } \\
\text { (feet) }\end{array}$ & $\begin{array}{l}\text { Depth of } \\
\text { bottom } \\
\text { (feet) }\end{array}$ & Driller's name & $\begin{array}{l}\text { Year } \\
\text { drilled }\end{array}$ \\
\hline 20N/04E-32E02 & $\begin{array}{l}\text { Topsoil } \\
\text { Brown sand and gravel } \\
\text { Brown sand, gravel, and clay } \\
\text { Gray sand and gravel, some clay } \\
\text { Brown silty sand and clay } \\
\text { Brown sand and clay, some fine gravel, water 3-4 gpm } \\
\text { Brown sand and clay, some gravel } \\
\text { Gray sand and gravel, some clay } \\
\text { Gray silty sand and clay } \\
\text { Brown silty sand, some clay } \\
\text { Brown silty sand and gravel, water } 2 \text { gpm } \\
\text { Brown silty sand, seams of clay, and cemented sand } \\
\text { Brown sand and gravel, some clay, water } 2 \text { gpm } \\
\text { Gray sand and clay } \\
\text { Gray sand, gravel and clay, water } 3 \text { gpm } \\
\text { Gray sand, clay, and wood } \\
\text { Gray sand and coarse gravel, water } 10 \mathrm{gpm}\end{array}$ & $\begin{array}{r}1 \\
4 \\
16 \\
13 \\
24 \\
2 \\
20 \\
26 \\
4 \\
43 \\
8 \\
46 \\
9 \\
33 \\
11 \\
24 \\
11\end{array}$ & $\begin{array}{r}1 \\
5 \\
21 \\
34 \\
58 \\
60 \\
80 \\
106 \\
110 \\
153 \\
161 \\
207 \\
216 \\
249 \\
260 \\
284 \\
295\end{array}$ & S-K Pumps & 1992 \\
\hline 20N/04E-32H02 & $\begin{array}{l}\text { Dark brown, gravelly sandy silt, moist } \\
\text { Brown sandy gravel, moist to wet } \\
\text { Brown-gray sand with silt interbeds, wet } \\
\text { Gray gravelly sand with silt interbeds, wet } \\
\text { Gray silt, dry } \\
\text { Gray to brown, sandy silt, wet } \\
\text { Brown sandy, very silty gravel, moist } \\
\text { Brown silty gravelly sand, wet } \\
\text { Brown sandy gravel, wet } \\
\text { Brown very gravelly sand, wet } \\
\text { Brown slightly silty, sandy gravel } \\
\text { Brown gravelly sand, silt lense at } 138 \mathrm{ft} \text {, wet } \\
\text { Brown sandy gravel, wet } \\
\text { Brown gravelly sand, wet } \\
\text { Gray silt, dry }\end{array}$ & $\begin{array}{r}15 \\
13 \\
50 \\
5 \\
15 \\
9 \\
8 \\
5 \\
9 \\
4 \\
3 \\
16 \\
5 \\
4 \\
11\end{array}$ & $\begin{array}{r}15 \\
28 \\
78 \\
83 \\
98 \\
107 \\
115 \\
120 \\
129 \\
133 \\
136 \\
152 \\
157 \\
161 \\
172\end{array}$ & Hartcrowser & 1992 \\
\hline
\end{tabular}


Appendix 2.--Drillers' lithologic logs of wells used in construction of hydrogeologic sections, in the Tacoma-Puyallup area, Washington--Continued

\begin{tabular}{|c|c|c|c|c|c|}
\hline $\begin{array}{l}\text { Local } \\
\text { well number }\end{array}$ & Driller's description of materials & $\begin{array}{l}\text { Thickness } \\
\text { (feet) }\end{array}$ & $\begin{array}{l}\text { Depth of } \\
\text { bottom } \\
\text { (feet) }\end{array}$ & Driller's name & $\begin{array}{l}\text { Year } \\
\text { drilled }\end{array}$ \\
\hline 20N/04E-32J02 & $\begin{array}{l}\text { Clayey peat, some clay } \\
\text { Medium-coarse sand, fine gravel, some clay, water at } 36 \mathrm{ft} 10 \mathrm{gpm} \\
\text { Sand and gravel } \\
\text { Medium coarse sand } \\
\text { Sharp sand, several 4-inch discs of gravel } \\
\text { Fine sand } \\
\text { Gravel, } 1.5 \text { inches } \\
\text { Fine sand } \\
\text { Clay, fine sand, some gravel, water } \\
\text { Gravel, } 4 \text { inches } \\
\text { Sand } \\
\text { Sand, large gravel, clay particles, water } \\
\text { Very coarse sand and large percent of gravel } \\
\text { Sand and gravel, water, test } 1,500 \text { gpm dd } 5 \mathrm{ft}, 12 \text { inch casing } \\
\text { Coarse sand and gravel, water flowing } \\
\text { Coarse gravel, some sand } \\
\text { Coarse gravel and sand, water flowing, aprox } 500 \mathrm{gpm} \\
\text { Gravel, coarse clean sand } \\
\text { Blue clay }\end{array}$ & $\begin{array}{r}23 \\
13 \\
10 \\
4 \\
13 \\
10 \\
1 \\
4 \\
29 \\
1 \\
4 \\
3 \\
5 \\
5 \\
6 \\
9 \\
10 \\
7 \\
7 \\
10 \\
2\end{array}$ & $\begin{array}{r}23 \\
36 \\
46 \\
50 \\
63 \\
73 \\
74 \\
78 \\
107 \\
108 \\
112 \\
115 \\
120 \\
126 \\
135 \\
145 \\
152 \\
162 \\
164\end{array}$ & Jansen & 1945 \\
\hline 20N/04E-33A01 & $\begin{array}{l}\text { Topsoil } \\
\text { Black sand, some gravel } \\
\text { Black silty sand, some gravel } \\
\text { Log } \\
\text { Black silty sand, some gravel } \\
\text { Black, clean coarse sand } \\
\text { Black silty sand and gravel } \\
\text { Black clean medium sand with silt and wood, peat balls } \\
\text { Silt and peat } \\
\text { Black silty fine sand } \\
\text { Black very fine sand } \\
\text { Black medium sand, wood, water } \\
\text { Fine silty sand and wood } \\
\text { Light fine silty sand, peat, gravel }\end{array}$ & $\begin{array}{r}2 \\
16 \\
7 \\
2 \\
3 \\
10 \\
8 \\
52 \\
5 \\
50 \\
30 \\
20 \\
7 \\
22 \\
42\end{array}$ & $\begin{array}{r}2 \\
18 \\
25 \\
27 \\
30 \\
40 \\
48 \\
100 \\
105 \\
135 \\
155 \\
162 \\
184 \\
226\end{array}$ & Oelke & 1984 \\
\hline
\end{tabular}


Appendix 2.--Drillers' lithologic logs of wells used in construction of hydrogeologic sections, in the Tacoma-Puyallup area, Washington--Continued

\begin{tabular}{|c|c|c|c|c|c|}
\hline $\begin{array}{l}\text { Local } \\
\text { well number }\end{array}$ & Driller's description of materials & $\begin{array}{l}\text { Thickness } \\
\text { (feet) }\end{array}$ & $\begin{array}{l}\text { Depth of } \\
\text { bottom } \\
\text { (feet) }\end{array}$ & Driller's name & $\begin{array}{l}\text { Year } \\
\text { drilled }\end{array}$ \\
\hline $\begin{array}{l}\text { 20N/04E-33A01-- } \\
\text { continued }\end{array}$ & $\begin{array}{l}\text { Medium fine sand, with silt streaks, water bearing } \\
\text { Siltstone } \\
\text { Silt with gravel } \\
\text { Silt, some gravel } \\
\text { Gray hard silty gravel } \\
\text { Black medium sand } \\
\text { Coarse sand, some wood and gravel } \\
\text { Gray silty gravel }\end{array}$ & $\begin{array}{r}14 \\
11 \\
14 \\
30 \\
10 \\
15 \\
21 \\
4\end{array}$ & $\begin{array}{l}240 \\
251 \\
265 \\
295 \\
305 \\
320 \\
341 \\
345\end{array}$ & & \\
\hline $20 \mathrm{~N} / 04 \mathrm{E}-34 \mathrm{~B} 01$ & $\begin{array}{l}\text { Sand and clay } \\
\text { Gravel }\end{array}$ & $\begin{array}{r}35 \\
7\end{array}$ & $\begin{array}{l}35 \\
42\end{array}$ & Charlton & Unk \\
\hline $20 \mathrm{~N} / 04 \mathrm{E}-34 \mathrm{C} 01$ & $\begin{array}{l}\text { Sand } \\
\text { Sand with a little gravel, water } \\
\text { Sand, some water } \\
\text { Sandy clay } \\
\text { Sand } \\
\text { Brown clay and sand } \\
\text { Quicksand } \\
\text { Clay and gravel } \\
\text { Fine sandy clay } \\
\text { Fine silt, heaving } \\
\text { Blue clay } \\
\text { Gravel, some sand }\end{array}$ & $\begin{array}{r}34 \\
2 \\
94 \\
24 \\
18 \\
18 \\
13 \\
2 \\
42 \\
5 \\
8 \\
4\end{array}$ & $\begin{array}{r}34 \\
36 \\
130 \\
154 \\
172 \\
190 \\
203 \\
205 \\
247 \\
252 \\
260 \\
264\end{array}$ & Webber & 1947 \\
\hline $20 \mathrm{~N} / 04 \mathrm{E}-35 \mathrm{~A} 02$ & $\begin{array}{l}\text { Topsoil } \\
\text { Black and gray sand } \\
\text { Sand, some water } \\
\text { Gray hardpan } \\
\text { Sand, sulfer water } \\
\text { Gray hardpan } \\
\text { Gray claybound sand } \\
\text { Green clay } \\
\text { Cemented sand and gravel, seepage } \\
\text { Sand and gravel, water }\end{array}$ & $\begin{array}{r}3 \\
22 \\
1 \\
9 \\
8 \\
8 \\
29 \\
14 \\
16 \\
6\end{array}$ & $\begin{array}{r}3 \\
25 \\
26 \\
35 \\
43 \\
51 \\
80 \\
94 \\
110 \\
116\end{array}$ & Richardson & 1981 \\
\hline
\end{tabular}


Appendix 2.--Drillers' lithologic logs of wells used in construction of hydrogeologic sections, in the Tacoma-Puyallup area, Washington--Continued

\begin{tabular}{|c|c|c|c|c|c|}
\hline $\begin{array}{l}\text { Local } \\
\text { well number }\end{array}$ & Driller's description of materials & $\begin{array}{c}\text { Thickness } \\
\text { (feet) }\end{array}$ & $\begin{array}{l}\text { Depth of } \\
\text { bottom } \\
\text { (feet) }\end{array}$ & Driller's name & $\begin{array}{l}\text { Year } \\
\text { drilled }\end{array}$ \\
\hline 20N/04E-35D01 & $\begin{array}{l}\text { Open hole } \\
\text { Gravel } \\
\text { Clay and sand } \\
\text { Sand and gravel } \\
\text { Clay } \\
\text { Sand } \\
\text { Gravel } \\
\text { Clay, silt and sand } \\
\text { Sand } \\
\text { Sand and shells } \\
\text { Fine sand }\end{array}$ & $\begin{array}{r}40 \\
28 \\
12 \\
5 \\
8 \\
7 \\
3 \\
22 \\
8 \\
13 \\
15\end{array}$ & $\begin{array}{r}40 \\
68 \\
80 \\
85 \\
93 \\
100 \\
103 \\
125 \\
133 \\
146 \\
161\end{array}$ & Service Hardware & 1955 \\
\hline 20N/04E-35E01 & $\begin{array}{l}\text { Sand and clay } \\
\text { Gravel }\end{array}$ & $\begin{array}{r}41 \\
5\end{array}$ & $\begin{array}{l}41 \\
46\end{array}$ & Charlton & 1942 \\
\hline 20N/04E-35M02 & $\begin{array}{l}\text { Topsoil } \\
\text { Gray sand and gravel } \\
\text { Brown silty sand } \\
\text { Gray silt and gravel } \\
\text { Silty sand and gray gravel } \\
\text { Brown sand and gravel } \\
\text { Gray clean gravel } \\
\text { Gray silt and gravel } \\
\text { Gray gravel } \\
\text { Brown silt, sand, and gravel } \\
\text { Brown silt and sand, some gravel } \\
\text { Gray sand } \\
\text { Brown sand and gravel } \\
\text { Silt and gravel } \\
\text { Brown silt, sand, and gravel } \\
\text { Fine clean angular gravel }\end{array}$ & $\begin{array}{r}3 \\
14 \\
19 \\
31 \\
15 \\
7 \\
13 \\
18 \\
14 \\
53 \\
83 \\
8 \\
12 \\
12 \\
10 \\
3\end{array}$ & $\begin{array}{r}3 \\
17 \\
36 \\
67 \\
82 \\
89 \\
102 \\
120 \\
134 \\
187 \\
270 \\
278 \\
290 \\
302 \\
312 \\
315\end{array}$ & Oelke & 1991 \\
\hline
\end{tabular}


Appendix 2.--Drillers' lithologic logs of wells used in construction of hydrogeologic sections, in the Tacoma-Puyallup area, Washington--Continued

\begin{tabular}{|c|c|c|c|c|c|}
\hline $\begin{array}{l}\text { Local } \\
\text { well number }\end{array}$ & Driller's description of materials & $\begin{array}{l}\text { Thickness } \\
\text { (feet) }\end{array}$ & $\begin{array}{l}\text { Depth of } \\
\text { bottom } \\
\text { (feet) }\end{array}$ & Driller's name & $\begin{array}{l}\text { Year } \\
\text { drilled }\end{array}$ \\
\hline $\begin{array}{l}\text { 20N/04E-35M02-- } \\
\text { continued }\end{array}$ & $\begin{array}{l}\text { Tight gravel } \\
\text { Brown tight silty gravel } \\
\text { Brown sandy fine tight gravel } \\
\text { Brown sandy medium angular gravel, water bearing }\end{array}$ & $\begin{array}{r}4 \\
16 \\
2 \\
4\end{array}$ & $\begin{array}{l}319 \\
335 \\
337 \\
341\end{array}$ & & \\
\hline
\end{tabular}


Appendix 3.--Water-quality data in the Tacoma-Puyallup area, Washington

\section{EXPLANATION}

Location: $\quad \mathbf{u}$, well located in uplands; $\mathrm{v}$, well located in Puyallup River valley.

Land surface altitude:

In feet above sea level. Most altitudes were assigned from topographic maps (1:24,000 with 10- or 20-foot contour intervals) and are generally accurate to within 10 feet. In steep terrain, or where the precise location of the well is in doubt, the error may be as great as 50 feet. Some wells $(<10$ percent) have been surveyed and are accurate to within 1 foot.

Well depth:

Hydrogeologic unit:

General symbols and abbreviations:
Feet below land surface.

Hydrogeologic unit tapped by well: g, gravel; Qvr, Vashon recessional deposits; Qvt, Vashon till; Qc1, Qc2, and Qc3 are aquifer units; $Q \mathbf{f l}$ is a semi-confining unit.

--, no data; deg. C, degrees Celsius; $\mathrm{mm}$ of $\mathrm{Hg}$, millimeters of mercury; $\mu \mathrm{S} / \mathrm{cm}$, microSiemens per centimeter at 25 degrees Celsius; $\mathrm{mg} / \mathrm{L}$, milligrams per liter; <, less than; $\mu \mathrm{g} / \mathrm{L}$, micrograms per liter; cols. per $100 \mathrm{~mL}$, colonies per 100 milliliters; $B^{*}$, indicates results based on colony count outside acceptable range (non-ideal colony count); $\mathrm{pCi} / \mathrm{L}$, picocuries per liter; sigma, one standard deviation. 
Appendix 3.--Water-quality data in the Tacoma-Puyallup area, Washington--Continued

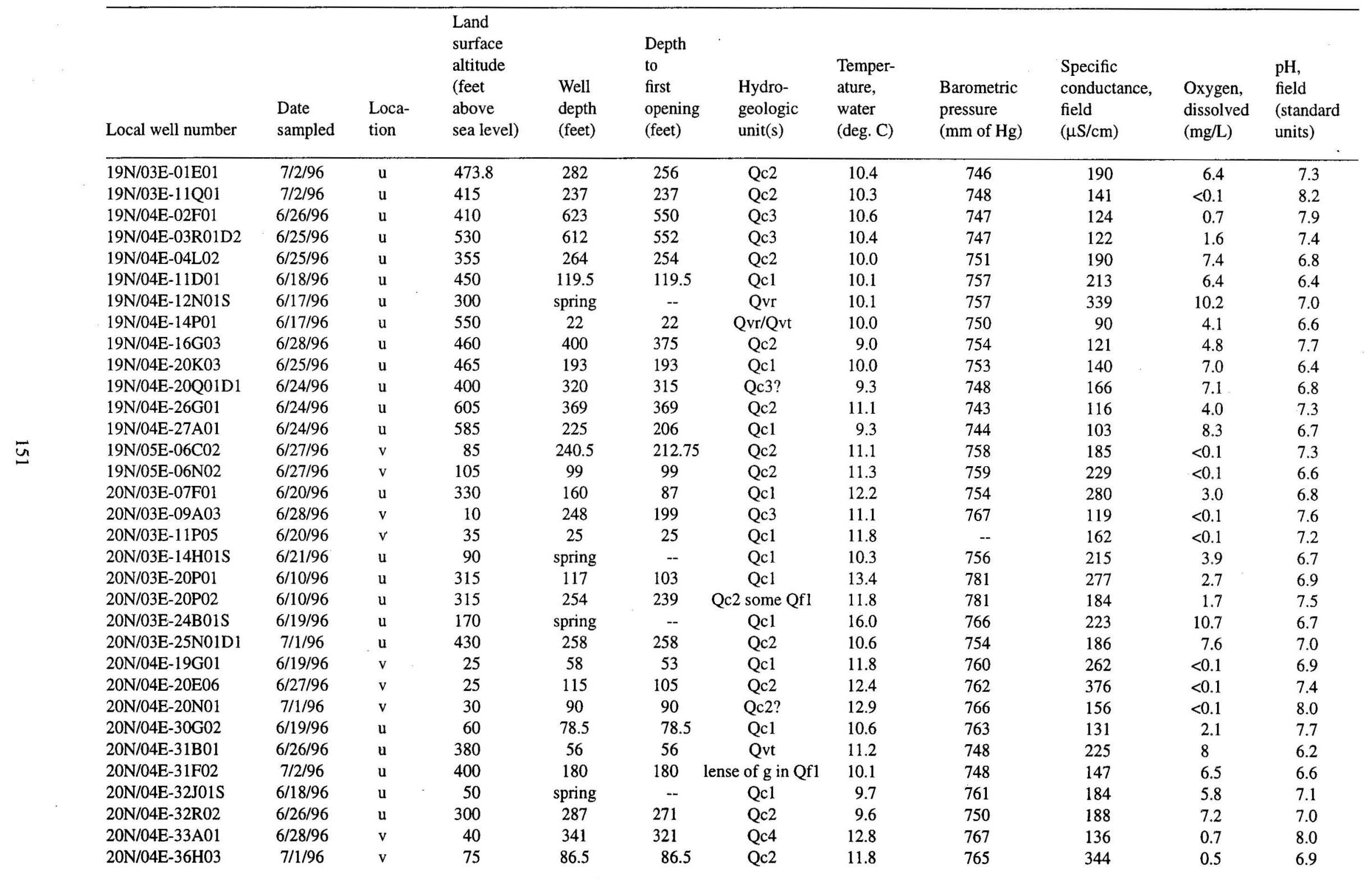


Appendix 3.--Water-quality data in the Tacoma-Puyallup area, Washington--Continued

\begin{tabular}{|c|c|c|c|c|c|c|c|c|c|c|c|c|}
\hline $\begin{array}{l}\text { Carbonate, } \\
\text { field } \\
(\mathrm{mg} / \mathrm{L} \\
\left.\text { as } \mathrm{CaCO}_{3}\right)\end{array}$ & $\begin{array}{l}\text { Bicarbonate, } \\
\text { field }(\mathrm{mg} / \mathrm{L} \\
\left.\text { as } \mathrm{HCO}_{3}\right)\end{array}$ & $\begin{array}{l}\text { Nitrate } \\
\text { plus } \\
\text { nitrite, } \\
\text { dissolved } \\
\text { (mg/L } \\
\text { as } \mathrm{N} \text { ) }\end{array}$ & $\begin{array}{l}\text { Calcium, } \\
\text { dissolved } \\
(\mathrm{mg} / \mathrm{L} \\
\text { as } \mathrm{Ca})\end{array}$ & $\begin{array}{l}\text { Magne- } \\
\text { sium, } \\
\text { dissolved } \\
\text { (mg/L } \\
\text { as } \mathrm{Mg} \text { ) }\end{array}$ & $\begin{array}{l}\text { Sodium, } \\
\text { dissolved } \\
\text { (mg/L } \\
\text { as Na) }\end{array}$ & $\begin{array}{l}\text { Potassium, } \\
\text { dissolved } \\
(\mathrm{mg} / \mathrm{L} \\
\text { as K) }\end{array}$ & $\begin{array}{l}\text { Chloride, } \\
\text { dissolved } \\
(\mathrm{mg} / \mathrm{L} \\
\text { as } \mathrm{Cl})\end{array}$ & $\begin{array}{l}\text { Sulfate, } \\
\text { dissolved } \\
(\mathrm{mg} / \mathrm{L} \\
\left.\text { as } \mathrm{SO}_{4}\right)\end{array}$ & $\begin{array}{l}\text { Fluoride, } \\
\text { dissolved } \\
\text { (mg/L } \\
\text { as F) }\end{array}$ & $\begin{array}{l}\text { Silica, } \\
\text { dissolved } \\
(\mathrm{mg} / \mathrm{L} \\
\left.\text { as } \mathrm{SiO}_{2}\right)\end{array}$ & $\begin{array}{l}\text { Arsenic, } \\
\text { dissolved } \\
(\mu \mathrm{g} / \mathrm{L} \\
\text { as As) }\end{array}$ & $\begin{array}{l}\text { Barium, } \\
\text { dissolved } \\
(\mu \mathrm{g} / \mathrm{L} \\
\text { as } \mathrm{Ba})\end{array}$ \\
\hline 0 & 95 & 2.3 & 19 & 8.3 & 7.0 & 1.3 & 5.1 & 6.4 & $<0.1$ & 28 & $<1.0$ & -- \\
\hline 0 & 86 & 0.05 & 13 & 4.7 & 9.3 & 1.9 & 1.9 & 1.5 & 0.1 & 25 & 10 & -- \\
\hline 0 & 74 & $<0.05$ & 9.7 & 6.1 & 5.7 & 2.1 & 1.6 & 3.3 & 0.1 & 47 & 4.0 & -- \\
\hline 0 & 73 & 0.09 & 9.6 & 6.0 & 5.2 & 1.8 & 1.7 & 3.6 & 0.1 & 45 & 2.0 & $<2.0$ \\
\hline 0 & 97 & 2.6 & 17 & 9.3 & 6.2 & 2.0 & 5.9 & 6.0 & $<0.1$ & 32 & 1.0 & -. \\
\hline 0 & 115 & 2.2 & 22 & 9.3 & 7.4 & 1.3 & 5.2 & 4.9 & $<0.1$ & 32 & $<1.0$ & -. \\
\hline 0 & 190 & 4.4 & 30 & 21 & 9.1 & 2.3 & 6.8 & 7.5 & $<0.1$ & 35 & $<1.0$ & 6.0 \\
\hline 0 & 27 & 1.1 & 7.4 & 2.4 & 5.6 & 0.5 & 5.6 & 5.2 & $<0.1$ & 16 & $<1.0$ & 3.0 \\
\hline 0 & 68 & 0.55 & 9.5 & 6.0 & 4.7 & 2.2 & 2.1 & 3.3 & $<0.1$ & 41 & 2.0 & -- \\
\hline 0 & 64 & 2.0 & 13 & 6.5 & 5.5 & 1.5 & 4.3 & 5.1 & $<0.1$ & 26 & $<1.0$ & -- \\
\hline 0 & 80 & 2.0 & 15 & 7.7 & 5.7 & 1.8 & 5.8 & 4.5 & $<0.1$ & 30 & $<1.0$ & -- \\
\hline 0 & 66 & 0.07 & 9.5 & 5.2 & 5.0 & 2.4 & 1.8 & 3.9 & 0.1 & 45 & 2.0 & -- \\
\hline 0 & 51 & 0.39 & 9.9 & 3.5 & 4.4 & 1.1 & 3.2 & 4.9 & $<0.1$ & 25 & $<1.0$ & -- \\
\hline 0 & 111 & $<0.05$ & 18 & 6.1 & 11 & 2.8 & 5.4 & 2.8 & 0.2 & 41 & 8.0 & -- \\
\hline 0 & 135 & $<0.05$ & 20 & 6.0 & 8.1 & 2.9 & 4.7 & 7.6 & 0.3 & 60 & $<1.0$ & -- \\
\hline 0 & 142 & 3.2 & 21 & 19 & 8.6 & 2.0 & 6.9 & 16 & $<0.1$ & 34 & 1.0 & 6.0 \\
\hline 0 & 72 & $<0.05$ & 9.4 & 5.3 & 6.2 & 1.3 & 2.0 & 2.5 & 0.1 & 47 & 4.0 & -- \\
\hline 0 & 95 & 0.08 & 12 & 8.1 & 7.6 & 2.4 & 3.8 & 6.0 & 0.1 & 52 & 3.0 & 3.0 \\
\hline 0 & 106 & 1.5 & 18 & 11 & 7.5 & 2.2 & 6.5 & 11 & $<0.1$ & 37 & 1.0 & 5.0 \\
\hline 0 & 135 & 2.5 & 22 & 17 & 9.1 & 1.8 & 7.1 & 19 & $<0.1$ & 33 & $<1.0$ & 6.0 \\
\hline 0 & 92 & 2.0 & 16 & 9.9 & 6.9 & 2.0 & 6.0 & 8.4 & $<0.1$ & 35 & 2.0 & -- \\
\hline 0 & 83 & 6.4 & 20 & 9.0 & 8.4 & 1.2 & 10 & 12 & $<0.1$ & 36 & $<1.0$ & 3.0 \\
\hline 0 & 86 & 2.0 & 16 & 8.9 & 6.7 & 1.6 & 8.6 & 5.9 & $<0.1$ & 31 & $<1.0$ & -- \\
\hline 0 & 168 & 0.05 & 19 & 11 & 10 & 2.3 & 7.5 & 0.9 & 0.1 & 55 & $<1.0$ & 16 \\
\hline 0 & 253 & $<0.05$ & 28 & 18 & 20 & 6.8 & 3.5 & 1.2 & 0.5 & 58 & $<1.0$ & -- \\
\hline 0 & 97 & 0.07 & 11 & 5.9 & 9.9 & 2.7 & 2.0 & 0.3 & 0.2 & 48 & $<1.0$ & -- \\
\hline 0 & 79 & 0.17 & 11 & 6.3 & 6.0 & 1.2 & 2.2 & 2.5 & 0.1 & 33 & 2.0 & $<2$ \\
\hline 0 & 98 & 4.9 & 25 & 7.7 & 8.8 & 1.4 & 5.9 & 11 & $<0.1$ & 34 & $<1.0$ & -- \\
\hline 0 & 62 & 2.2 & 13 & 5.3 & 6.4 & 1.2 & 6.3 & 5.7 & $<0.1$ & 30 & 2.0 & -- \\
\hline 0 & 89 & 2.0 & 16 & 8.8 & 6.1 & 2.2 & 5.4 & 6.9 & $<0.1$ & 32 & 2.0 & 3.0 \\
\hline 0 & 91 & 2.6 & 16 & 9.1 & 6.1 & 2.1 & 5.9 & 6.2 & $<0.1$ & 32 & 1.0 & -- \\
\hline 0 & 83 & $<0.05$ & 11 & 5.6 & 7.8 & 2.2 & 1.6 & 3.2 & 0.1 & 40 & $<1.0$ & -- \\
\hline 0 & 193 & 0.06 & 39 & 14 & 8.4 & 3.5 & 7.9 & 23 & $<0.1$ & 62 & $<1.0$ & 24 \\
\hline
\end{tabular}


Appendix 3.--Water-quality data in the Tacoma-Puyallup area, Washington--Continued

\begin{tabular}{|c|c|c|c|c|c|c|c|c|c|c|c|}
\hline $\begin{array}{l}\text { Boron, } \\
\text { dissolved } \\
(\mu \mathrm{g} / \mathrm{L} \\
\text { as B })\end{array}$ & $\begin{array}{l}\text { Cadmium, } \\
\text { dissolved } \\
(\mu \mathrm{g} / \mathrm{L} \\
\text { as } \mathrm{Cd})\end{array}$ & $\begin{array}{l}\text { Chromium, } \\
\text { dissolved } \\
(\mu \mathrm{g} / \mathrm{L} \\
\text { as } \mathrm{Cr})\end{array}$ & $\begin{array}{l}\text { Copper, } \\
\text { dissolved } \\
(\mu \mathrm{g} / \mathrm{L} \\
\text { as } \mathrm{Cu})\end{array}$ & $\begin{array}{l}\text { Iron, } \\
\text { dissolved } \\
(\mu \mathrm{g} / \mathrm{L} \\
\text { as } \mathrm{Fe})\end{array}$ & $\begin{array}{l}\text { Lead, } \\
\text { dissolved } \\
(\mu \mathrm{g} / \mathrm{L} \\
\text { as } \mathrm{Pb})\end{array}$ & $\begin{array}{l}\text { Manganese, } \\
\text { dissolved } \\
(\mu \mathrm{g} / \mathrm{L} \\
\text { as } \mathrm{Mn})\end{array}$ & $\begin{array}{l}\text { Silver, } \\
\text { dissolved } \\
(\mu \mathrm{g} / \mathrm{L} \\
\text { as } \mathrm{Ag})\end{array}$ & $\begin{array}{l}\text { Zinc, } \\
\text { dissolved } \\
(\mu \mathrm{g} / \mathrm{L} \\
\text { as } \mathrm{Zn})\end{array}$ & $\begin{array}{l}\text { Selenium, } \\
\text { dissolved } \\
(\mu \mathrm{g} / \mathrm{L} \\
\text { as } \mathrm{Se})\end{array}$ & $\begin{array}{l}\text { Coliform, } \\
\text { total, } \\
\text { immediate } \\
\text { M-Endo } \\
\text { medium } \\
\text { (cols. per } \\
100 \mathrm{~mL} \text { ) }\end{array}$ & $\begin{array}{l}\text { Streptococci, } \\
\text { fecal, } \\
\text { KF Agar } \\
\text { (cols. per } \\
100 \mathrm{~mL} \text { ) }\end{array}$ \\
\hline -- & -- & -- & -- & $<3$ & -- & $<1$ & -- & -. & -- & $<1$ & $<1$ \\
\hline -- & -- & -- & -- & 8 & -- & 96 & -- & .. & -- & 27 & $<1$ \\
\hline -- & -- & -- & -- & 4 & -- & 10 & -- & .. & -- & $<1$ & $<1$ \\
\hline 16 & $<1.0$ & $<1.0$ & $<1.0$ & $<3$ & $<1.0$ & 11 & $<1.0$ & 4 & $<1$ & $<1$ & $<1$ \\
\hline -- & -- & -- & -- & $<3$ & -- & $<1.0$ & -- & -- & -- & $<1$ & $<1$ \\
\hline 7.6 & -- & .. & .- & 6 & -- & $<1.0$ & -- & -- & -- & $<1$ & $<1$ \\
\hline 32 & $<1.0$ & $<1.0$ & $<1.0$ & $<3$ & $<1.0$ & $<1.0$ & $<1.0$ & $<3$ & $<1$ & $<1$ & $<1$ \\
\hline 27 & $<1.0$ & $<1.0$ & $<1.0$ & $<3$ & $<1.0$ & 1 & $<1.0$ & 3 & $<1$ & $2 \mathrm{~B}^{*}$ & $<1$ \\
\hline -- & -. & -- & -- & 7 & -- & $<1.0$ & -- & .- & -- & $<1$ & $<1$ \\
\hline 12 & -- & -- & -- & $<3$ & -. & $<1.0$ & -- & .- & -- & $<1$ & $<1$ \\
\hline 14 & -- & -- & -- & $<3$ & --. & $<1.0$ & ..- & -- & -- & $<1$ & $<1$ \\
\hline -- & -- & -- & -- & 10 & -- & 2 & -. & -- & -- & $<1$ & $<1$ \\
\hline-- & -- & -- & -- & $<3$ & -- & $<1.0$ & -- & -- & -- & $<1$ & $<1$ \\
\hline 25 & -- & -- & -- & 25 & -- & 28 & -- & -- & .- & $<1$ & $<1$ \\
\hline 34 & -- & - & -- & 12,000 & -- & 1,100 & -- & .. & -- & $<1$ & $<1$ \\
\hline 21 & $<1.0$ & $<1.0$ & 3 & 8 & 2 & 2 & $<1.0$ & 88 & $<1$ & $<1$ & $<1$ \\
\hline -- & $-\therefore$ & -- & -- & 220 & -- & 89 & -- & -- & -- & $<1$ & $<1$ \\
\hline 21 & $<1.0$ & $<1.0$ & $<1.0$ & 8 & $<1.0$ & $<1.0$ & $<1.0$ & 9 & $<1$ & $<1$ & $<1$ \\
\hline 16 & $<1.0$ & $<1.0$ & $<1.0$ & $<3$ & $<1.0$ & $<1.0$ & $<1.0$ & $<3$ & $<1$ & $8 \mathrm{~B}^{*}$ & $1 \mathrm{~B}^{*}$ \\
\hline 19 & $<1.0$ & $<1.0$ & $<1.0$ & 6 & $<1.0$ & 1 & $<1.0$ & 11 & $<1$ & $<1$ & $<1$ \\
\hline -- & .- & .. & -- & $<3$ & -- & $<1.0$ & -- & .. & -- & $1 \mathrm{~B}^{*}$ & $<1$ \\
\hline 15 & $<1.0$ & $<1.0$ & 1 & 4 & $<1.0$ & $<1.0$ & $<1.0$ & $<3$ & $<1$ & 90 & $2 \mathrm{~B}^{*}$ \\
\hline -- & -- & -- & -. & $<3$ & -- & $<1.0$ & -- & -- & -- & $<1$ & $<1$ \\
\hline 22 & $<1.0$ & $<1.0$ & $<1.0$ & 12,000 & $<1.0$ & 420 & $<1.0$ & 4 & $<1$ & $<1$ & $<1$ \\
\hline 68 & .- & -- & -- & 650 & -- & 300 & -- & -- & -- & $<1$ & $<1$ \\
\hline 23 & -- & -- & -- & 140 & .- & 65 & -- & -- & -- & $<1$ & $3 \mathrm{~B}^{*}$ \\
\hline 15 & $<1.0$ & $<1.0$ & 2 & 15 & $<1.0$ & 4 & $<1.0$ & 18 & $<1$ & $27 \mathrm{~B} *$ & $<1$ \\
\hline 13 & -- & -- & -- & 38 & -- & 1 & -- & -- & -- & $<1$ & $<1$ \\
\hline 16 & -- & -- & -- & 18 & .- & 3 & -- & .. & -- & $<1$ & $<1$ \\
\hline 9.6 & $<1.0$ & $<1.0$ & 1 & $<3$ & $<1.0$ & $<1$ & $<1.0$ & $<3$ & $<1$ & $<1$ & $2 \mathrm{~B}^{*}$ \\
\hline -- & .- & -- & -- & $<3$ & -- & $<1$ & -. & -- & -- & $<1$ & $<1$ \\
\hline 23 & -- & -- & -- & 24 & .. & 51 & -- & .- & -- & $<1$ & $<1$ \\
\hline 29 & $<1.0$ & $<1.0$ & $<1.0$ & 5,400 & $<1.0$ & 410 & $<1.0$ & $<3$ & $<1$ & $3 \mathrm{~B}^{*}$ & $<1$ \\
\hline
\end{tabular}


Appendix 3.--Water-quality data in the Tacoma-Puyallup area, Washington--Continued

\begin{tabular}{|c|c|c|c|c|c|c|c|c|c|c|c|}
\hline $\begin{array}{l}\text { Alka- } \\
\text { linity, } \\
\text { field } \\
(\mathrm{mg} / \mathrm{L} \text { as } \\
\mathrm{CaCO}_{3} \text { ) }\end{array}$ & $\begin{array}{l}\text { Solids, } \\
\text { residue, } \\
\text { at } 180 \\
\text { deg. C } \\
\text { dissolved } \\
(\mathrm{mg} / \mathrm{L})\end{array}$ & $\begin{array}{l}\text { Solids, } \\
\text { sum of } \\
\text { consti- } \\
\text { tuents, } \\
\text { dissolved } \\
(\mathrm{mg} / \mathrm{L})\end{array}$ & $\begin{array}{l}\text { Mercury, } \\
\text { dissolved } \\
(\mu \mathrm{g} / \mathrm{L} \\
\text { as } \mathrm{Hg})\end{array}$ & $\begin{array}{l}\text { RN-222 } \\
\text { two } \\
\text { sigma } \\
\text { total } \\
(\mathrm{pCi} / \mathrm{L})\end{array}$ & $\begin{array}{l}\text { Radon, } \\
222 \text { total } \\
\text { (pCi/L) }\end{array}$ & $\begin{array}{l}E \text {-coli } \\
\text { with Mug } \\
\text { Agar } \\
\text { (cols. per } \\
100 \mathrm{~mL} \text { ) }\end{array}$ & $\begin{array}{l}\text { Carbon, } \\
\text { organic } \\
\text { total } \\
\text { (mg/L } \\
\text { as C) }\end{array}$ & $\begin{array}{l}\text { Hardness, } \\
\text { total } \\
(\mathrm{mg} / \mathrm{L} \text { as } \\
\left.\mathrm{CaCO}_{3}\right)\end{array}$ & $\begin{array}{l}\text { Methylene } \\
\text { blue active } \\
\text { substances } \\
(\mathrm{mg} / \mathrm{L})\end{array}$ & $\begin{array}{l}\text { Sodium, } \\
\text { percent }\end{array}$ & $\begin{array}{l}\text { Sodium } \\
\text { plus } \\
\text { Potassium, } \\
\text { percent }\end{array}$ \\
\hline 78 & 132 & 132 & -- & 28 & 810 & -- & 0.3 & 82 & -- & 16 & 21 \\
\hline 71 & 97 & 100 & -- & 23 & 460 & -- & 0.1 & 52 & -- & 28 & 44 \\
\hline 61 & 118 & 112 & -. & 25 & 470 & -- & 0.1 & 49 & -. & 20 & 37 \\
\hline 60 & 105 & 109 & $<0.1$ & 23 & 440 & -- & 0.1 & 49 & $<0.02$ & 19 & 28 \\
\hline 78 & 134 & 138 & -- & -. & -- & -- & -- & 81 & -- & 14 & 17 \\
\hline 95 & 139 & 148 & -- & $\ldots$ & -- & -- & -- & 93 & $<0.02$ & 15 & 19 \\
\hline 156 & 216 & 225 & $<0.1$ & -- & -- & -- & -- & 160 & $<0.02$ & 11 & 14 \\
\hline 22 & 57 & 61 & $<0.1$ & -- & -- & $2 B^{*}$ & -- & 28 & $<0.02$ & 30 & 45 \\
\hline 56 & 99 & 105 & -. & 28 & 450 & -- & 0.3 & 48 & -- & 17 & 27 \\
\hline 52 & 94 & 102 & -- & -- & -- & -. & $\ldots$ & 59 & $<0.02$ & 17 & 23 \\
\hline 66 & 124 & 119 & -- & 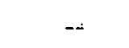 & -- & -- & -- & 69 & $<0.02$ & 15 & 21 \\
\hline 54 & 112 & 106 & -- & 24 & 450 & -. & 0.4 & 45 & -- & 19 & 31 \\
\hline 210 & 72 & 79 & -- & - & -- & -- & -- & 39 & -- & 20 & 28 \\
\hline 91 & 135 & 142 & -- & 23 & 430 & -- & 0.9 & 70 & $<0.02$ & 25 & 39 \\
\hline 111 & 200 & 189 & -- & -- & -- & -- & -- & 75 & $<0.02$ & 19 & 29 \\
\hline 116 & 186 & 192 & $<0.1$ & -- & -- & -. & -. & 130 & $<0.02$ & 13 & 16 \\
\hline 59 & 105 & 110 & -- & 25 & 260 & -- & 0.5 & 45 & -- & 23 & 34 \\
\hline 78 & 129 & 139 & 0.1 & -. & -- & -- & -- & 63 & $<0.02$ & 20 & 31 \\
\hline 87 & 142 & 152 & $<0.1$ & -- & -. & -- & -- & 90 & $<0.02$ & 15 & 21 \\
\hline 111 & 182 & 186 & $<0.1$ & 27 & 550 & -- & 0.3 & 120 & $<0.02$ & 14 & 18 \\
\hline 75 & 130 & 138 & -- & 28 & 570 & -- & 0.7 & 81 & -- & 16 & 22 \\
\hline 68 & 167 & 166 & $<0.1$ & -- & -- & $43 B^{*}$ & -- & 87 & $<0.02$ & 18 & 23 \\
\hline 71 & 129 & 130 & -- & - & -- & -- & - & 77 & -- & 16 & 57 \\
\hline 138 & 192 & 201 & $<01$ & -- & -- & -- & $\ldots$ & 93 & $<0.02$ & 19 & 27 \\
\hline 207 & 246 & 261 & -- & -- & -- & -- & - & 140 & 0.02 & 23 & 36 \\
\hline 80 & 119 & 128 & -- & -- & -- & -- & -- & 52 & $<0.02$ & 29 & 48 \\
\hline 65 & 93 & 102 & $<0.1$ & -- & -- & $23 B^{*}$ & -- & 53 & $<0.02$ & 20 & 27 \\
\hline 80 & 150 & 164 & -- & .. & -- & -- & -- & 94 & $<0.02$ & 17 & 22 \\
\hline 50 & 110 & 108 & -- & -- & -- & -- & -- & 54 & $<0.02$ & 20 & 28 \\
\hline 73 & 125 & 130 & $<0.1$ & 22 & 450 & -. & 0.7 & 76 & $<0.02$ & 15 & 21 \\
\hline 75 & 128 & 134 & -- & -- & -- & -- & -- & 77 & -- & 15 & 21 \\
\hline 68 & 104 & 112 & -. & -- & -- & -- & -. & 51 & $<0.02$ & 25 & 39 \\
\hline 158 & 261 & 259 & $<0.1$ & -- & -- & $2 B^{*}$ & 2.8 & 160 & $<0.02$ & 11 & 15 \\
\hline
\end{tabular}

